\title{
KẾT QUẢ SớM PHẪU THUÂTT TẮC RUỘT DO BÃ THỨC ĂN TẠI BỆNH VIỆN BACH MAI
}

\begin{abstract}
Seang
TÓM TẮT

Mục tiêu: Mô tả đặc điểm lâm sàng, cận lâm sàng và kết quả sớm phẫu thuật tắc ruột do bã thức ăn. Đối tượng và phương pháp nghiền cứu: mô tả hồi cứu các trường hợp được chẩn đoán sau mổ tắc ruột non do bã thức ăn từ 01-2016 đến 12-2020 tại Bệnh viện Bạch Mai. Kết quả: 63 bệnh nhân với tuổi thường gặp trên 51 tuổi $(85,7 \%)$ và tỉ lệ nam/nữ là 0,66 . Đau bụng là triệu chứng luôn có với $98,4 \%$, chủ yếu đau cơn $66,7 \%$, nôn $77,8 \%$ và bí trung đại tiện $71,4 \%$. Hình ảnh tắc ruột rõ trên $X Q$ bụng không chuẩn bị là $71,4 \%$, trên siểu âm $50,8 \%$ và trên cắt lớp vi tính $82,6 \%$ nhưng không xác định được nguyên nhân do bã thức ăn. Vị trí bã thức ăn ở hồi tràng chiếm tỷ lệ cao nhất $(58,7 \%)$. Xử lý tổn thương: mở ruột non lấy bã thức ăn $(95,2 \%)$, dồn bã thức ăn xuống đại tràng $(4,8 \%)$, mở dạ dày lây bã kết hợp $(22,2 \%)$. Kết quả điều trị giai đoạn sớm tốt: không có tai biến phẫu thuật, biến chứng nhiễm trùng vết mổ 5 $(7,9 \%)$, thời gian nằm viện sau mổ trung bình $8,17 \pm$ 2,61 ngày. Kết luận: Chẩn đoán tình trạng tắc ruột thường không khó nhhưng xác định nguyên nhân do bã thức ăn là rất khó. Điều trị ngoại khoa vẫn là biện pháp chủ yếu và có tính an toàn và hiệu quả.
\end{abstract}

Tư khoá: Tắc ruột, bã thức ăn, phấu thuật.

\section{SUMMARY}

EARLY RESULTS OF SURGICAL TREATMENT OF INTESTINAL OBSTRUCTION CAUSED BY PHYTOBEZOAR AT BACH MAI HOSPITAL

Objective: Description of clinical and paraclinical characteristics and early results of surgery of small intestinal obstruction caused by phytobezoars. Subjects and methods: Retrospective study including all the cases of post-operative diagnosis with intestinal obstruction due to phytobezoars from 012016 to 12- 2020 in Bach Mai Hospital. Results: 63 patients with common age over 51 years old $(87.5 \%)$; male/female percentage: 0,66. Abdominal pain was always present $(98.4 \%)$, mostly was intermittent $66.7 \%$; vomiting $77.8 \%$; no exaust $71.4 \%$. The typical image of small bowel obstruction on Xray was $71,4 \%$; on ultra sound was $50,8 \%$ and on CTscan was $82.6 \%$, but the cause wasn't confirmed. The location of phytobezoar was of $58.7 \%$ in ileum. The extraction of phytobezoar by jejunotomy or ileotomy was the most common method $(95.2 \%)$, the phytobezoar was milked into the cecum in 3 patients $(4.8 \%)$ and

\footnotetext{
${ }^{1}$ Đai hoc Y Hà Nôi

²Bệnh viện Bạch Mai

Chịu trách nhiệm chính: Trân Hiếu Học

Email: hieuhoc1305@gmail.com

Ngày nhận bài: 24/6/2021

Ngày phản biên khoa học: 29/7/2021

Ngày duyệt bài: 19/8/2021
}

combinated gastrotomy was in $22.2 \%$. The early results was good, there are no operative accidents and no mortality, fewer postoperative complications (wound infection $7.9 \%$ ). The hospital stay was of $8.17 \pm 2.61$ days. Conclusion: The diagnosis of intestinal obstruction was usually quite easy but it is very difficult to determine the cause of phytobezoars. The surgical treatment was essential with safety and effectivity.

Keywords: Intestinal obstruction, phytobezoar, surgery.

\section{I. ĐẶT VẤN ĐỀ}

Tắc ruột do bã thức ăn (BTA) thường tiến triển từ từ nên việc phát hiện các yếu tố nguy cơ cũng như chẩn đoán sớm và phẫu thuật kịp thời sẽ đem lại kết quả điều trị tốt và tránh được những biến chứng nặng nề[1]. Bệnh cảnh với hình thái lâm sàng đa dạng, việc chẩn đoán chính xác nguyên nhân tắc ruột trước mổ còn gặp nhiều khó khăn và tỷ lệ chẩn đoán chính xác tắc ruột do bã thức ăn còn thấp chỉ từ 3\% - 18\% [2]. Ngày nay với sự phát triển của các phương tiện chẩn đoán hình ảnh đã giúp cho việc chẩn đoán tắc ruột do bã thức ăn có nhiều cải thiện hơn $[2,3,4]$.

Tại Việt Nam cũng đã có một số công trình nghiển cứu về tắc ruột do bã thức ăn tuy nhiên việc xác định nguyên nhân tắc ruột còn muộn và có nhiều biến chứng nặng nề. Ngày nay với những thói quen ăn uống đa dạng, bệnh cảnh lâm sàng phong phú hơn, các phương tiện thăm dò trong chẩn đoán cũng tốt hơn. Việc chẩn đoán và xử trí bệnh ở giai đoạn sớm hiện nay cần phải được đánh giá thực tế và chính xác hơn, Vì vậy chúng tôi thực hiện đề tài này với mục tiêu: Mô tả đặc điểm lầm sàng, cận lâm sàng và kêt quả phẫu thuật tắc ruột do bã thức ăn tại Bệnh viện Bạch Mai từ 2016 - 2020.

\section{II. ĐỐI TƯỢNG VÀ PHƯƠNG PHÁP NGHIÊN CỨU 2.1. Đối tượng nghiên cứu}

*Tiêu chuẩn lựa chọn: bệnh nhân $(B N)$ người lớn cả hai giới được chẩn đoán sau mổ tắc ruột do bã thức ăn, được phẫu thuật giải quyết nguyên nhân, có hồ sơ bệnh án đủ thông tin cần cho nghiên cứu.

*Tiêu chuẩn loại trừ: có bã thức ăn trong đường tiêu hoá nhưng không phải là nguyên nhân gây tắc ruột, có bã thức ăn trong dạ dày nhưng không có tắc ruột.

\subsection{Phương pháp nghiên cứu}


*Thiết kế nghiên cứu: mô tả hồi cứu

*Địa điểm, thời gian: Khoa Ngoại Tổng hợp - Bệnh viện Bạch Mai, từ tháng 1/2016 đến tháng 12/2020.

\section{*Biến số nghiên cứu:}

- Tuổi, giới tính.

- Triệu chứng: đau bụng, nôn, bí trung - đại tiện, chướng bụng, quai ruột nổi, rắn bò, sờ thấy khối, nhiệt độ, mạch, huyết áp tối đa.

- Kết quả cận lâm sàng: X quang, CT Scaner, Siêu âm ổ bụng.

\section{KẾT QUẢ NGHIÊN CỨU}

\section{Bảng 1. Phân bố theo tuổi và giới}

\begin{tabular}{|c|c|c|c|c|c|c|}
\hline \multirow{3}{*}{ Tuổi } & \multicolumn{4}{|c|}{ Giới } & \multirow{2}{*}{\multicolumn{2}{|c|}{ Tổng }} \\
\hline & \multicolumn{2}{|c|}{ Nam } & \multicolumn{2}{|c|}{$\mathbf{N} \tilde{u}$} & & \\
\hline & $\mathbf{N}$ & $\%$ & $\mathbf{n}$ & $\%$ & $\mathbf{n}$ & $\%$ \\
\hline$<31$ & 0 & $0 \%$ & 2 & $3,2 \%$ & 2 & $3,2 \%$ \\
\hline $31-40$ & 1 & $1,6 \%$ & 2 & $3,2 \%$ & 3 & $4,8 \%$ \\
\hline $41-50$ & 4 & $6,4 \%$ & 0 & $0 \%$ & 4 & $6,4 \%$ \\
\hline $51-60$ & 7 & $11,1 \%$ & 5 & $7,9 \%$ & 12 & $19,0 \%$ \\
\hline $61-70$ & 6 & $9,5 \%$ & 9 & $14,3 \%$ & 15 & $23,8 \%$ \\
\hline$>70$ & 7 & $11,1 \%$ & 20 & $31,7 \%$ & 27 & $42,8 \%$ \\
\hline Tống & 25 & $39,7 \%$ & 38 & $60,3 \%$ & 63 & $100 \%$ \\
\hline
\end{tabular}

Nhân xét: Tuối: Tuối trung bình là $66,3 \pm 17,4$ tuối, trẻ nhất là 18 tuối và nhiều nhất là 98 tuổi. Độ tuối gă̆p chủ yếu trên 51 tuổi với 54 bênh nhân $(85,7 \%)$.

Giới: Tỉ lệ nữ/nam: 1,5/1 tỉ lệ nam/ nữ là 0,66

Bảng 2. Đặc điểm lấm sàng

\begin{tabular}{|c|c|c|c|}
\hline \multicolumn{2}{|c|}{ Triệu chứng } & Số bệnh nhân & Số (\%) \\
\hline \multirow{6}{*}{$\begin{array}{c}\text { Tiền sử } \\
\text { (Ngoại khoa, } \\
\text { Nội khoa) }\end{array}$} & Cắt dạ dày & 8 & \\
\hline & Khâu lỗ thủng dạ dày & 1 & \\
\hline & Tắc ruột sau mố & 3 & \\
\hline & Viêm loét dạ dày tá tràng & 5 & \\
\hline & Đái tháo đường & 4 & \\
\hline & Bệnh hô hấp, tim mạch & 13 & \\
\hline \multicolumn{2}{|c|}{ Về ăn uống (hồng, măng, cam quýt, chuối xanh) } & 7 & \\
\hline \multirow{3}{*}{ Đau bụng } & Đau cơn & 42 & 66,7 \\
\hline & Đau âm ỉ, liên tục & 20 & 31,7 \\
\hline & Không mô tả rõ̃ & 1 & 1,6 \\
\hline \multicolumn{2}{|r|}{ Nôn } & 49 & 77,8 \\
\hline \multicolumn{2}{|c|}{ Bí trung - đại tiện } & 45 & 71,4 \\
\hline \multirow{4}{*}{ Chướng bụng } & Chướng mềm & 38 & 60,3 \\
\hline & Chướng có phản ứng & 14 & 22,2 \\
\hline & Không chướng & 10 & 15,9 \\
\hline & Không mô tả rõ & 1 & 1,6 \\
\hline \multirow{3}{*}{ Quai ruột nổi } & Có quai ruột nối & 8 & 12,7 \\
\hline & Không có quai ruột nối & 39 & 61,9 \\
\hline & Không mô tả rõ & 16 & 25,4 \\
\hline \multirow{3}{*}{ Rắn bò } & Có rằn bò & 11 & 17,4 \\
\hline & Không có rắn bò & 40 & 63,5 \\
\hline & Không mô tả rõ & 12 & 19,1 \\
\hline \multirow{3}{*}{ Sờ thây khối } & Sờ thấy u cục & 10 & 15,9 \\
\hline & Không sờ thấy & 44 & 69,8 \\
\hline & Không mô tả & 9 & \\
\hline
\end{tabular}

- Vị trí khôi bã thức ăn, phương pháp phẫu thuật,. chứng sau mổ, ngày nằm viện sau mổ, tình trạng khi ra viện.

*Cỡ mẫu: Toàn bô với cách chon mẫu thuận tiên.

2.3. Phân tích và xử lý số liệu: Số liệu được thu thập và xử lý với phần mềm SPSS 20.0

2.4. Đạo đức nghiên cứu: Nghiên cứu hồi cứu, không can thiệp vào bệnh nhân. Các thông tin liên quan đến đối tượng nghiên cứu được giữ bí mật.
- Kết quả điều trị: tai biến trong mổ, biến 


\begin{tabular}{|c|c|c|c|}
\hline \multirow{3}{*}{ Mạch } & $<80$ & 45 & 71,4 \\
\cline { 2 - 4 } & $80-100$ & 17 & 27 \\
\cline { 2 - 4 } & $>100$ & 1 & 1,6 \\
\hline \multirow{3}{*}{ Huyết áp tối đa } & $<90$ & 7 & 11,1 \\
\cline { 2 - 4 } & $90-140$ & 54 & 85,7 \\
\cline { 2 - 4 } Nhiệt độ & $>140$ & 2 & 3,2 \\
\cline { 2 - 4 } & $<37,5^{\circ} \mathrm{C}$ & 2 & 88,9 \\
\hline & $37,5-38,5^{\circ} \mathrm{C}$ & 4 & 3,2 \\
\hline & $38,5-39,5^{\circ} \mathrm{C}$ & 1 & 6,3 \\
\hline
\end{tabular}

Nhận xét: Đau bụng là triệu chứng bao giờ cũng có, chướng bụng là triệu chứng thường thấy $82,5 \%$. Dấu hiệu rắn bò gặp ở số ít bệnh nhân 17,4\%. It trường hợp sờ thấy khối 15,9\%. Tình trạng toàn thân ít có thay đổi.

Bảng 3. Kết quả thăm dò hình ảnh

\begin{tabular}{|c|c|c|c|}
\hline Biện pháp & Kết quả & Số bệnh nhân & Tỷ lệ (\%) \\
\hline \multirow{2}{*}{$\begin{array}{l}\text { XQ bụng không } \\
\text { chuẩn bị }\end{array}$} & Có mức nước - mức hơi điến hình & 45 & 71,4 \\
\hline & Mức nước- mức hơi không điến hình & 12 & 19 \\
\hline \multirow{5}{*}{ Siêu âm } & Bã thức ăn trong dạ dày & 1 & 1,6 \\
\hline & Hình ảnh tắc ruốt & 32 & 50,8 \\
\hline & Khối trong ố bụng & 1 & 1,6 \\
\hline & Dịch ố bụng & 26 & 41,2 \\
\hline & Bình thường & 3 & 4,8 \\
\hline \multirow{4}{*}{$\begin{array}{c}\text { CT Scaner ổ } \\
\text { bụng }\end{array}$} & Khối u trong ố bụng & 0 & 0 \\
\hline & Giãn quai ruột & 10 & 15,8 \\
\hline & Tắc ruột & 52 & 82,6 \\
\hline & Bình thường & 1 & 1,6 \\
\hline
\end{tabular}

Nhân xét: Triêu chứng điến hình của XQ ố bung găp ở đa số bênh nhân 71,4\%. Hình ảnh mức nước - mức hơi không điển hình gặp $19 \%$. Hình ảnh tắc ruột trên siêu âm gặp $50,8 \%$, có $41,2 \%$ dịch ổ bụng. Trên CT có tình ảnh tắc ruột 82,6\%.

Bảng 4. Vị trí của khôi bã thức ăn trong đường tiêu hóa

\begin{tabular}{|c|c|c|c|}
\hline & & & \\
\hline Vị trí & Đặc điếm & Số BN & Tỷ lệ (\%) \\
\hline \multirow{3}{*}{ Gây tắc ruột } & Hống tràng & 26 & 41,3 \\
\hline & Hồi tràng & 28 & 44,4 \\
\hline & Góc hồi manh tràng & 9 & 14,3 \\
\hline \multicolumn{2}{|r|}{ Tống } & 63 & 100 \\
\hline \multirow{3}{*}{ Kết hợp đồng thời } & Hông tràng+ Dạ dày & 5 & 7,9 \\
\hline & Hồi tràng + Dạ dày & 7 & 11,1 \\
\hline & Góc hồi manh tràng + Dạ dày & 2 & 3,2 \\
\hline
\end{tabular}

Nhân xét: Vị trí bã thức ăn thường gặp nhất ở hồi tràng chiếm 45,5\% và hỗng tràng 40,2\%, vị trí ở góc hồi manh tràng chiếm 14,3\%. Vị trí kết hợp thức ăn ở dạ dày là $18,2 \%$.

Bảng 5. Phương pháp phấu thuật

\begin{tabular}{|c|c|c|c|}
\hline & Phương pháp phâu thuật & Số BN & Tỷ lệ (\%) \\
\hline \multirow{2}{*}{$\begin{array}{c}\text { Giải quyết nguyên nhân } \\
\text { gây tắc }\end{array}$} & Mớ ruột đơn thuânn lấy bã thức ăn & 60 & 95,2 \\
\cline { 2 - 4 } & Dồn bã thức ăn xuống đại tràng & 3 & 4,8 \\
\cline { 2 - 4 } & Tống số & $\mathbf{6 3}$ & $\mathbf{1 0 0}$ \\
\hline $\begin{array}{c}\text { Thủ thuâ̂t phối hợp với bã } \\
\text { thức ắn ở vị trí khác }\end{array}$ & Mở dạ dày + mở ruột lấy BTA & 12 & 19,0 \\
\hline & Mở dạ dày + dồn BTA xuống đại tràng & 2 & 3,2 \\
\hline
\end{tabular}

Nhận xét: Hầu hết là mở ruột lấy BTA $95,2 \%$, có 14 bệnh nhân (22,2\%) được mở dạ dày để lây BTA phối hợp

Kết quả điêu trị: không có tai biến trong mổ, biến chứng sau mổ có 5 trường hợp $(7,9 \%)$ nhiễm trùng vết mổ điều trị bằng thay băng và kháng sinh, không có biến chứng áp xe tồn dư, không có biến chứng cần can thiệp phẫu thuật lại.

Thời gian nằm viện sau mổ trung bình: $8,17 \pm 2,61$ ngày, sớm nhất là 4 ngày và muộn nhất là 16 ngày. 


\section{BÀN LUẬN}

*Tuổi và giới: Tuổi mắc bênh trong nhóm nghiên cứu là khá cao, trung bình là $66,3 \pm 17,4$ tuổi, trẻ nhất là 18 tuổi và nhiều tuổi nhất là 98 tuổi, gặp chủ yếu trên 51 tuổi với $85,7 \%$. Kết quả này cũng tương tự Dirican với độ tuổi trung bình là 64 (từ 30-94) tuổi [4]. Các tác giả khác cũng cho thấy bệnh thường gặp ở lứa tuổi trên 60 [1],[5]. Nữ giới nhiều hơn nam, đặc biệt tuổi $>70$ thì tỷ lệ nữ bị tắc ruột do bã thức ắn cao hơn hẳn. Trong khi đó nhiều nghiên cứu lại cho thấy nam thường bị nhiều hơn nữ, chẳng hạn Nguyễn Hồng Sớn và CS có 18 nam và 12 nữ (nam/nữ $=1,5 / 1$ ),

* Lâm sàng: Trong số những triệu chứng ban đầu của tắc ruột do bã thức ăn, đau bụng là triệu chứng hay gặp nhất và cũng là triệu chứng điển hình. Qua thống kê cho thấy đau bunng là triệu chứng gặp nhiều nhất, chiếm 98,4\%. Kết quả nghiên cứu của chúng tôi cũng giống với kết quả của Nguyễn Hồng Sơn, của Trân Hiếu Học là $100 \%$ [5],[7]. Trong nghiên cứu của chúng tôi thì đau cơn là triệu chứng điển hình của tắc ruột, găp 42 bệnh nhẩn, chiếm $66,7 \%$. Tuỳ theo vị trí tắc ruột do bã thức ăn, thời gian nôn gần bữa ăn hay xa, hoặc khi biểu hiện bệnh, bệnh nhân có ăn tiếp khổng mà chất nôn có thế khác nhau. Tuy nhiên trong tắc ruột do bã thức ăn có lẽ diễn biến của bệnh kéo dài nên bệnh nhân vẫn ăn uống được.Chướng bụng là triệu chứng gặp ở 52 BN $(82,5 \%)$, trong đó bụng chướng mêm là $60,3 \%$. Kết quả này cũng tương tự nghiên cứu của các tác giả khác. Tỷ lệ này gặp trong nghiên cứu của Nguyễn Hồng Sơn là $90 \%$ [5], của Trần Hiếu Học là 72,1\%.

Quai ruột nổi là biểu hiện của tình trạng ruột tăng nhu động nhằm thắng được áp lực đường tiêu hóa để đẩy hơi và dịch tiểu hóa ra ngoài. Dấu hiệu quai ruột nổi gặp ở 8 bệnh nhân, chiếm $12,7 \%$. Theo nghiên cứu của Trần Hiếu Học tỷ lệ gặp là 37,2\% [7]. Dấu hiệu rắn bò dấu hiệu đặc trưng của tắc ruột cơ giới thể hiện tình trạng tăng nhu động của ruột. Chúng tôi thấy dấu hiệu rắn bò gặp ở 11 bệnh nhân, chiếm 17,4\%, cũng tương tự như của Trần Hiếu Học tỷ lệ này là 19,7\%[7], còn Nguyễn Hồng Sơn có tỷ lệ thây dấu hiệu quai ruột nổi, rắn bò $20 \%$ [5]. Dấu hiệu quai ruột nổi, rẳn bò là những dấu hiệu quan trọng trong tắc ruột cơ giới nói chung, cũ̃ng như trong tắc ruột nói riêng. Các dấu hiệu này xuất hiện trong cợn đau, do vậy không phải lúc nào cũng phát hiện được các dấu hiệu này. Sờ thấy khối khi thăm khám ổ bụng cũng là dấu hiệu gợi ý nguyên nhân gây tắc ruột. Tuy nhiên phát hiện khối thường gặp khó khăn trong những trường hợp thành bụng dầy, trong cơn đau, bụng chướng, khối bã thức ăn đã di chuyển xuống thấp. Hơn nữa khi sờ thấy khối cùng với các triêuu chứng tắc ruột, đặc biệt ở người già thường nghĩ đến tắc ruột do u đại tràng, ở trẻ em được chẩn đoán là tắc ruột do giun, một số ít trường hợp nghĩ đến tắc ruột do bã thức ăn. Trong nghiên cứu của chúng tôii, sờ thấy khối u gặp ở 10 bệnh nhân, chiếm $15,9 \%$. Tỷ lệ này trong các nghiên cứu của Nguyễn Hồng Sớn chỉ là 3,3\% [5]. Chỉ số mạch, nhiệt độ và huyết áp tối đa trong tắc ruột do bã thức ắn thường ít có biến loạn, trù̀ một số trường hợp nhỏ tắc ruột do bã thức ăn đã gây biến chứng hoặc đến muộn.

Về những tiền sử ngoại khoa, trong nghiên cứu có $8 \mathrm{BN}$ đã mổ cắt dạ dày, 1 khâu thủng dạ dày và 3 có tắc ruột và về nội khoa có $5 \mathrm{BN}$ điều trị viêm loét da dày - tá tràng, $4 \mathrm{BN}$ đái tháo đường. Đã phẫu thuật về dạ dày là yếu tố nguy cơ dẫn đến hình thành bã thức ăn được nhiều tác giả đề cập và cơ chế hình thành bã thức ăn ở những trường hợp này đã được giải thích khá rõ ràng $[3,4,5]$. Đặc biệt trong nghiên cứu của Dirican (2009) thì có tới $12 / 24 \mathrm{BN}(50 \%)$ có tiền sử mổ bao gồm cắt thần kinh $X$ và hang vị 10 , cắt bán phần da dày 1 và khâu lỗ thủng 1 [4]. Thức ăn cũng là yếu tố liên quan quan trọng của việc hình thành bã thức ăn được nhiều nghiên cứu nêu ra và giải thích rõ cơ chế liên quan đến axit tannic trong thức ăn $[3,4,6]$. Nghiên cứu của chúng tôi cũng có tỷ lệ bệnh nhân ăn các loại quả dễ tạo nên bã thức ăn chiếm 14,2\%.

* Cận lâm sàng: Trong nghiên cứu này, trên XQ ổ bụng không chuẩn bị dấu hiệu tắc ruột điển hình là mức nước - mức hơi gặp 71,4\%, hình ảnh không điển hình $19 \%$. Kết quả của chúng tôi cũng phù hợp với các tác giả khác, độ nhạy của XQ bụng không chuẩn bị trong chẩn đoán tắc ruột dao động $79,4 \%$ - 100\%[4,7]. Khả năng chẩn đoán chính xác tắc ruột trong nghiên cứu của Nguyễn Hồng Sơn là 96,7\% nhưng không thể biết được nguyên nhân là bã thức ăn [5]. Ngày nay siểu âm và CT scanner là thăm dò cân lâm sàng được áp dụng rộng rãi và có tỷ lệ chẩn đoán nguyên nhân khá cao. Nghiên cứu của chúng tôi cho thấy trên siêu âm một nửa số trường hợp có hình ảnh tắc ruôt $(50,8 \%)$ và chỉ 1 trường hợp thấy bã thức ăn trong dạ dày, không phát hiện được nguyên nhân bã thức ăn gây tắc ruột. Cả $100 \%$ BN được chụp CT Scaner, chúng tôi găp hình ảnh tắc ruột có 52 bênh nhân $(82,6 \%)$, hình ảnh giãn quai ruột có 10 bệnh nhân $(15,8 \%)$. Nghiên cứu của Nguyễn Hồng 
Sơn cũng thấy siêu âm và CT chẩn đoán được tắc ruột lần lượt là $52,4 \%$ và $92,9 \%$ nhưng siêu âm không xác định được nguyên nhân bã thức ăn còn CT chẩn đoán được nguyên nhân $57,1 \%$ [5]. Trong khi đó Dirican siêu âm cho 11/24 bệnh nhân thì nghi ngờ 2 có bã thức ăn [4]. Chụp CT Scaner ổ bụng là vô giá trong chẩn đoán xác định tắc ruột nhưng để khẳng định nguyên nhân là bã thức ăn thì tỷ lệ không cao, như của Gök là $8 \%$ [1] còn theo Dirican [4] lại thấy bằng chứng hoặc nghi ngờ có bã thức ăn trong nhiêuu trường hợp $(77,1 \%)$. Các phát hiện CT Scaner chung ở tất cả các bệnh nhân là hình ảnh khí lốm đốm và một khối hình trứng khu trú hoặc khối tròn trong lòng ruột với rìa đều và cấu trúc bên trong không đồng nhất [6].

*Phẫu thuật: Vị trí bã thức ăn thường gặp ở hồi tràng chiếm $58,7 \%$ hơn là hống tràng $41,3 \%$ và $14 \mathrm{BN}$ có kết hợp bã thức ăn ở dạ dày là $22,2 \%$. Điều này phù hợp với lý thuyết, bã thức ăn hình thành ở dạ dày, khi di chuyển xuống ruột thì hay gây tắc ruột ở đoạn cuối hồi tràng do đường kính ruột nhỏ và có van hồi manh tràng. Kết quả này tương tự nghiên cứu của Trần Hiếu Học [7] ở hồi tràng chiếm $62,8 \%$, của Nguyễn Hồng Sơn 69\% [5], của Yau là 80\% [8]. Tỷ lệ mở ruột lấy BTA trong nghiên cứu của chúng tôi là $95,2 \%$, có 14 bệnh nhân $(22,2 \%)$ được mở dạ dày để lấy BTA phối hợp. Mở ruột lấy hay dồn đầy bã thức ăn xuống manh tràng tùy theo tính chất, độ cứng của khối bã. Nếu có thể thì nên dồn đây xuống tránh mở ruột, như Gök có tỷ lệ là $55 \%(11 / 20 \mathrm{BN})[1]$, Dirican là $45,8 \%[4]$, của Nguyễn Hồng Sơn là $53,8 \%$. Cũng có tác giả khác có tỷ lệ mở ruột lấy bã thức ăn cao như Trần Hiếu Học là 80,2\% [5]. Ngày nay với sự phát triển của phẫu thuật nội soi thì phương pháp này đang tỏ ra có tính hiệu quả, an toàn áp dụng để điêu trị tắc ruột do bã thức ăn mà không thể điều trị bằng phương pháp điều trị nội khoa. Nguyễn Hồng Sơn có 4/30 mổ nội soi với $1 \mathrm{BN}$ phải chuyển mổ mở [5]. Các nghiên cứu đều cho thây phẫu thuật nội soi có thời gian phẫu thuật ngắn hơn, ít biến chứng sau mổ hơn và giảm thời gian nằm viện so với phẫu thuật mở $[5,8]$. Ngoài ra, nội soi can thiệp với ống nội soi dài được đưa tới hồi tràng để cắt nhỏ và gắp các mảnh bã thức ăn đã làm giảm đáng kể tỷ lệ phẫu thuật mổ mở $[1,4]$.

*Kết quả điều trị sớm: nghiên cứu chúng tôi cho thấy kết qỉa sớm nhìn chung tốt, không có tai biến trong mổ, không có tử vong và tỷ lệ biến chứng sau mố thấp, chỉ có $7,9 \%$ nhiễm trùng vết mổ. Các nghiên cứu cũng có kết quả khác nhau: Nguyễn Hồng Sơn có $10 \%$ tai biến trong mổ, $10 \%$ biến chứng và tử vong 3,3\% [5], Thời gian nằm viện sau mổ của chúng tôi là $8.17 \pm 2.61$ ngày (4-15 ngày) cũng tương đồng với nhiếu tác giả. Bệnh nhân của Nguyễn Hồng Sơn có ngày nằm viện 7,2 nhóm mổ mở và 6 ngày nhóm mổ nội soi. Nghiên cứu của Dirican có ngày nằm viện là $7 \pm 1$ ngày ở nhóm mở ruột lấy bã thức ăn và $4 \pm 2$ ngày ở nhóm dồn đẩy bã xuống manh tràng. Một số bệnh nhân có thời gian ra viện sau mổ kéo dài chủ yếu ở những bệnh nhân tuổi già, tình trạng ổ bụng bẩn, tình trạng dinh dưỡng kém, cân chăm sóc và hối sức sau mổ kéo dài hơn hoặc bị nhiễm trùng vết mổ.

\section{KẾT LUÂ̂N}

Tắc ruột do bã thức ăn không khó khăn nhiều trong chẩn đoán tình trạng tắc ruột nhưng rất khó xác định nguyên nhân. Các phương tiện thăm dò hình ảnh giúp ích cho chẩn đoán bệnh. Phẫu thuật dù mở ruột lấy bã thức ăn hay dồn đẩy bã xuống manh tràng đều cho kết quả tốt và việc kiểm tra dạ dày để lấy bã thức ăn phối hợp là việc làm hết sức cần thiết.

\section{TÀI LIẸU THAM KHẢO}

1. Gök AFK, Sönmez, R.E., Kantarcı T.R. et al. (2019). Discussing treatment strategies for acute mechanical intestinal obstruction caused by phytobezoar: A single-center retrospective study. Ulusal travma ve acil cerrahi dergisi = Turkish journal of trauma \& emergency surgery : TJTE. 25(5), 503-9.

2. Bouali M, Ballati A., Bakouri AE. et al. (2021). Phytobezoar: An unusual cause of small bowel obstruction. Annals of Medicine and Surgery. 62; 323-5.

3. Claro M., Santos DC, Silva AA, et al. (2021). When eating makes you sick - Gastric stump obstruction caused by a phytobezoar. A case report and literature review. nternational journal of surgery case reports. 79, $263-6$.

4. Dirican A, Unal B, Tatli F. et al. (2009). Surgical treatment of phytobezoars causes acute small intestinal obstruction. Bratislavske lekarske listy. $110(3), 158-61$.

5. Nguyê̂́n Hống Sơn, Lý Hữu Tuấn và Nguyễn văn Hải (2012). Dắc điểm lâm sàng, hình ảnh học và kết quá điều trị tắc ruột do bã thức ăn. Y Học TP. Hồ Chí Minh * Tập 16 * Phụ bản của Số 1 * 53-58.

6. Li L, Xue B, Zhao Q. et al. (2019). Observation on the curative effect of long intestinal tube in the treatment of phytobezoar intestinal obstruction. Medicine (Baltimore). 98(11), 1-6.

7. Trân Hiếu Học, Nguyến Ngọc Bích (2006). Một số nhận xét về tắc ruột do bã thức ăn điều trị tại khoa Nigoại bệnh viện Bạch Mai trong 7 năm (1999- 2005). Tạp chí Y học lâm sàng, số đặc biệt bệnh viện Bạch Mai năm 2006. 27-32.

8. Yau KK, Law BKB, Ha JPY et al. (2005). Laparoscopic Approach Compared With Conventional Open Approach for Bezoar-Induced Small-Bowel Obstruction. Archives of Surgery. 140(10), 972-5. 


\section{NGHIÊN CỨU TÌNH HÌNH VÀ MộT SỐ YẾU TỐ LIÊN QUAN ĐẾN RỐI LOAN LIPID MÁU TRONG BÊNNH VẢY NẾN TẠI BỆNH VIÊ̂N DA LIỄU THÀNH PHỐ CẦ THƠ NĂM 2020}

\section{TÓM TẮT}

Muc tiêu: Xác định tỉ lệ rối loạn lipid máu và các yếu tổ liên quan trên bệnh nhân vảy nến. Đối tượng và phương pháp: Nghiên cứu mô tả cắt ngang tiến cứu được tiến hành trên 90 bệnh nhân vảy nến điều trị tại Bệnh viện Da liếu Cần Thơ năm 2020. Kết quả: Tỉ lệ rối loạn lipid máu ở bệnh nhân vảy nến là $60 \%$, trong đó rối loan chiếm tỉ lê cao nhất là tăng Triglycerid $(33,3 \%)$, kế đến là giảm HDL chiếm 30\%, tăng Cholesterol toàn phần $(20 \%)$ và sau cùng là tăng LDL-c (12,2\%). Chưa tìm được các yếu tố liên quan làm thay đổi nồng đô lipid máu của bệnh nhân vảy nến mang ý nghĩa thống kê. Kết luận: Tỉ lệ rối loạn lipid máu trên bệnh nhân vảy nến cao nhưng vẫn chưa rõ nguyên nhân phía sau.

Tư khóa: Rối loạn lipid máu, vảy nến.

\section{SUMMARY \\ STUDY OF THE DYSLIPIDEMIA CONDITION AND ITS RISK FACTORS IN PSORIASIS PATIENTS AT CAN THO DERMATO- VENEROLOGY HOSPITAL IN 2020}

Objective: To determine the prevalenceand risk factors of dyslipidemia in psoriasis patient. Subjects and method: This is a prospective cross-sectional descriptive study conducted on 90 psoriasis patients treated at Can Tho Dermatology Hospital in 2020. Results: The prevalence of dyslipidemia in the disease psoriasis was $60 \%$, in which the disorder accounted for the highest proportion was hightriglycerid $(33.3 \%)$, followed by low HDL by $30 \%$, high cholesterol $(20 \%)$ and finally high LDL-C $(12.2 \%)$. However, we have not found any statistically significant risk factors of the disorder in psoriasis patients yet. Conclusion: The incidence of dyslipidemia in psoriasis patients was high, but the reasons behind that were still not clear.

Keywords: Dyslipidemia, psoriasis.

\section{I. ĐĂTT VẤN ĐỀ}

Vảy nến là một bệnh viêm mạn tính qua trung gian miễn dịch rất phổ biến [8]. Trước đây, bệnh vảy nến chỉ được xem là một tình trạng viêm da nhưng hiện nay được biết như là một bệnh viêm có tính hệ thống, giống như viêm

*Bênh viên Đai hoc Y Dước Cần Thơ

Chịu trách nhiệm chính: Huỳnh Văn Bá

Email: bs.ba_fob@yahoo.com.vn

Ngày nhận bài: 5/6/2021

Ngày phản biên khoa học: 22/6/2021

Ngày duyệt bài: 31/7/2021

Phạm Thanh Thảo*, Huỳnh Văn Bá*, Lạc Thị Kim Ngân*, Trần Nguyễn Anh Thư* khớp dạng thấp và bệnh Crohn [8], Gần đây có nhiều nghiên cứu cho thấy mối liên quan giữa vảy nến và bệnh tim mạch, theo đó vảy nến là yếu tố nguy cơ độc lập của các bệnh lý như đột quy, bệnh mạch vành... [8]. Trong khi đó, rối loạn lipid máu có vai trò rất quan trong trong quá trình xơ vữa động mạch và là một trong những yếu tố nguy cơ tim mạch chính yếu. Đã có nhiều nghiên cứu trên bệnh nhân vảy nến cho thấy sự biến đổi nồng độ các lipid gây xơ vữa như tắng triglyceride, cholesterol toàn phần, LDL-C (low-density lipoprotein cholesterol), VLDL-C(very-low-density lipoprotein cholesterol), và giảm nồng độ $\mathrm{HDL}-\mathrm{C}$ (high-density lipoprotein cholesterol) [5], [7]. Với mong muốn thực hiện nghiên cứu nhẳm đánh giá nồng độ lipid máu trên bệnh nhân vảy nến, từ đó giúp ích trong viêc tầm soát và điêuu trị sớm rối loan lipid máu nhằm phòng ngừa xơ mõ động mạch trên bệnh nhân vảy nến trên bệnh nhân vảy nến, cải thiện tiên lượng sống và chất lượng cuộc sống cho bệnh nhân, chúng tôi tiến hành đề tài này với những mục tiêu sau:

- Xác định tỷ lể rối loạn lipid máu của bênh nhân vảy nến điều trị tại Bệnh viện Da Liễu Thành Phố Cần Thơ năm 2020.

- Mô tả một số yếu tố liên quan đến rối loạn lipid máu của bệnh nhân vảy nến điều trị tại Bệnh viện Da Liễu Thành phố Cần Thơ năm 2020.

\section{II. ĐỐI TƯỢNG VÀ PHƯƠNG PHÁP NGHIÊN CỨU}

2.1. Đối tượng nghiên cứu: Tất cả bệnh nhân bị bệnh vảy nến đến khám và điều trị tại Bệnh viện Da liễu Thành phố Cần Thơ năm 2020.

Tiêu chuẩn chọn mấu:

- Chọn mẫu nghiên cứu là những bệnh nhân được chẩn đoán bệnh vảy nến điều trị tại Bệnh viện Da liễu Thành Phố Cần Thơ. Chẩn đoán chủ yểu dựa vào lâm sàng, cụ thể thương tổn là mảng hồng ban tróc vảy có $\geq 1$ trong các tính chất gợi ý: phân bố đối xứng; ở mặt duỗi chi; dấu hiệu Auspitz, thương tổn giới hạn rõ, vảy trắng bạc.

- Bệnh nhân chấp nhận tham gia nghiên cứu.

Tiêu chuẩn loại trừ:

- Người có bệnh gây tăng lipid máu thứ phát như: nhược giáp, tiểu đường, hội chứng thận hư, 
suy thận mạn, bênh mô liên kết.

- Có đang sử dụng các thuốc: ức chế beta, thiazide, corticosteroid, retinoids, cyclosporine, và những thuốc hạ lipid máu.

- Chỉ số khối cớ thể (BMI) >30.

- Có thai hoặc đang cho con bú.

\subsection{Phương pháp nghiên cứu}

Thiết kế nghiên cứu: Phương pháp nghiên cứu mô tả cắt ngang tiến cứu.

Cỡ mẫu và phương pháp chọn mẫu: Áp dụng công thức ước lượng một tỷ lệ với mức tin cậy $95 \%$, sai số cho phép $10 \%$ và tỷ lệ rối loạn lipid máu tham khảo theo Salihbegovic E. M. và cộng sự (2015) là 62,85\% [15], cõ̃ mẫu ước tính được là 90 bệnh nhân.

2.3. Nội dung nghiên cứu: - Đặc điểm chung của đối tượng nghiên cứu: tuổi, giới.

- Đặc điểm lâm sàng của bệnh vảy nến: tuổi khởi phát, thời gian mắc bệnh, triệu chứng cơ năng, tiên sử gia đình, vị trí tổn thương hiện tại, thể lâm sàng, độ nặng của bệnh theo PASI, diện tích vùng da bệnh.

- Tình trạng rối loạn lipid máu: nồng độ triglyceride (TG) máu, nồng độ cholesterol toàn phần (Cholesterol TP) máu, nồng độ LDL-C, nồng độ HDL-c. Bệnh nhân được xem là có rối loạn lipid máu khi có ít nhất một trong các tiêu chuẩn sau: Cholesterol TP $>6,2 \mathrm{mmol} / \mathrm{l}, \mathrm{TG} \geq 2,26$ $\mathrm{mmol} / \mathrm{l}$, LDL-C $\geq 4,13 \mathrm{mmol} / \mathrm{l}, \mathrm{HDL}-\mathrm{c}<1,03$ $\mathrm{mmol} / \mathrm{l}$ (theo ATP III, 2001).

- Các yếu tố liên quan đến rối loạn lipid máu: tiền sử gia đình, huyết áp (huyết áp tâm

thu và huyết áp tâm trương), cân nă̆ng, chiều cao, BMI, hoạt động thể lực, hút thuốc lá, uống rượu và chế độ ăn giàu chất béo.

2.4. Phương pháp thu thập và xử lý số liệu

- Hỏi bênh, thăm khám lâm sàng theo phiếu thu thập số liệu

- Xét nghiệm định lượng nồng độ lipid máu

- Số liệu được quản lý và xử lý bằng phần mềm Microsoft Excel 2016 và SPSS 18.0. Làm sạch số liệu trước khi tiến hành phân tích kết quả.

\section{KẾT QUẢ NGHIÊN CứU}

Trong 90 đối tượng nghiên cứu, nam giới chiếm $62,2 \%$ trong khi nữ chiếm $37,8 \%$, tỷ lệ nam/nữ xấp xỉ $3 / 2$. Độ tuổi trung bình là $43,4 \pm$ 15,7 , dao động từ người trẻ nhất là 9 tuổi đến cao nhất là 80 tuổi. Trong đó, nhóm tuổi chiếm tỷ lệ cao nhất là $35-60$ tuổi $(52,2 \%)$.

Các bệnh nhân khởi phát bệnh muộn sau 30 tuổi chiếm đa số, lên đến $72,2 \%$ so với nhóm khởi phát sớm chỉ 27,8\%. Độ tuổi khởi phát sớm nhất là 6 tuổi, lớn nhất 75 tuổi, trung bình 37,81 \pm 12 ,9. Thời gian bệnh dao động từ 2 tháng đến 35 năm, trung bình khoảng 6 năm. Những người mắc bệnh dưới 5 năm chiếm tỷ lệ cao nhất $(55,6 \%)$.

Về lâm sàng, tất cả các bệnh nhân đều có triệu chứng ngứa. Vị trí tương tổn thường gặp nhất là ở vùng chi trên $(81,1 \%)$ và than mình $(77,8 \%)$. Đa số vẫn là vảy nến thông thường (83,3\%), các dạng khác như vảy nến mủ, đỏ da toàn thân, viêm khớp vảy nến chỉ chiếm tỷ lệ nhỏ, lần lượt là $7,8 \% ; 6,7 \%$ và $2,2 \%$. Diện tích thương tổn tính theo BSA trung bình là $28,64 \%$

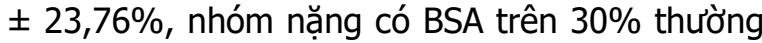
gặp nhất với tỷ lệ 38,9\%. Phân độ nặng của bệnh theo thang điểm PASI cho thẩy nhóm có mức độ trung bình chiếm tỷ lệ cao nhất $(48,9 \%)$ kế đến là nhóm nhẹ với tỷ lệ $38,9 \%$ và cuối cùng là nhóm nặng chiếm 12,2\%.

Bảng 1. Tý lệ rối loạn của các loại lipid máu trên bệnh nhân vảy nến

\begin{tabular}{|c|c|c|}
\hline $\begin{array}{c}\text { Loại rối loạn lipid } \\
\text { máu }\end{array}$ & $\begin{array}{c}\text { Tân số } \\
\text { (n) }\end{array}$ & $\begin{array}{c}\text { Tỷ lế } \\
\text { (\%) }\end{array}$ \\
\hline $\begin{array}{c}\text { Rối loạn lipid máu nói } \\
\text { chung }\end{array}$ & 54 & $60 \%$ \\
\hline Tăng Cholesterol TP & 18 & $20 \%$ \\
\hline Tăng TG & 30 & $33.3 \%$ \\
\hline Tăng LDL-C & 11 & $12,2 \%$ \\
\hline Giảm HDL-c & 27 & $30 \%$ \\
\hline Lipid máu bình thường & 36 & $30 \%$ \\
\hline
\end{tabular}

Có đến $60 \%$ bệnh nhân có rối loạn lipid máu, chiếm gần $2 / 3$ tổng số đối tượng nghiên cứu. Trong số này, dạng rối loạn phổ biến nhất là tăng TG $(33,3 \%)$, kế đến là giảm HDL-c $(30 \%)$, tăng Cholesterol TP (20\%) và thấp nhất là tăng LDL-c (12,2\%).

Khảo sát về các yếu tố liên quan đến tình trạng này, không tìm thấy sự liên quan giữa tỷ lệ rối loạn lipid máu và giới, tuổi, hoạt động thể lực, thói quen hút thuốc lá, uống rượu bia, huyết áp, BMI hay chễ độ ăn. Các yếu tố về mặt lâm sàng như tuổi khởi phát, thời gian mắc bệnh, tiên sử gia đình, thể bệnh hay mức độ nặng phân theo PASI và BSA cũng không ảnh hưởng đến tình trạng tăng lipid.

\section{BÀN LUẬN}

Tuổi trung bình của 90 bệnh nhân nghiên cứu là $43,4 \pm 15,7$, trong đó nhóm tuổi 35 - 60 chiếm tỷ lệ cao nhất $(52,2 \%)$. Kết quả này tương tự với nghiên cứu trước đây của Trương Lê Anh Tuấn (2012) nhưng thấp hơn tuổi trung bình trong nghiên cứu của Trương Thị Mộng Thường (2012) là 45,3. Nói chung, tuổi trung bình của bệnh nhân vảy nến trong những nghiên cứu nói 
trên khoảng 40, trong đô tuổi lao đông chính của xã hội. Bệnh vảy nến không chỉ tác động trực tiếp lên bản thân bệnh nhân và gia đình mà còn ảnh hưởng đến nền kinh tế xã hội [3], [4].

Về giới, nam chiếm $62,2 \%$ và nữ chiếm $37,8 \%$. Tỷ lệ nam/nữ là xấp xỉ $3 / 2$, kết quả này tương tự với Trương Lê Anh Tuấn (2012) và Trương Thị Mộng Thường (2012)[3], [4].

Nghiên cứu của chúng tôi bao gồm tất cả các thể lâm sàng của bệnh vảy nến, trong đó thể mảng chiếm tỷ lệ cao nhất $(83,3 \%)$, các thể còn lại lần lượt là vảy nến thể mủ $(7,8 \%)$, vảy nến đỏ da toàn thân $(6,7 \%)$, viêm khớp vảy nến $(2,2 \%)$. Vảy nến thể mảng cũng chiếm tỷ lệ cao nhất trong nghiên cứu của Trương Thị Mộng Thường với 74,6\%, Nguyễn Trong Hào là 78,1\% và nghiên cứu của Trương Lê Anh Tuấn với $80 \%$. Tỷ lệ này theo Fitzpatrick thậm chí còn cao hơn nữa, lên đến $90 \%$ [1], [4].

Vảy nến thông thường chiếm tỷ lệ cao nhất nên được nghiên cứu nhiều hơn cả về sinh bênh học, phương pháp điều trị và cả cách đánh giá mức độ bệnh thông qua chỉ số PASI và BSA. Trong số 75 bệnh nhân vảy nến mảng của chúng tôi, chỉ số PASI trung bình là 13,58 , với mức độ trung bình chiếm tỷ lệ cao nhất (48,9\%) kết quả này tương tự với nghiên cứu của Nguyễn Tất Thắng. Tuy nhiên, tỷ lệ này khác với nghiên cứu của Trương Lê Anh Tuấn và Nguyễn Trọng Hào là mức độ nhe chiếm tỷ lệ cao nhất (lần lượt là $65 \%$ và $58 \%$ ).

Về tình trang rối loạn lipid máu, tỷ lệ nói chung trên các đối tượng nghiên cứu là $60 \%$, trong đó tăng Triglycerid $(33,3 \%)$ chiếm tỷ lệ cao nhất, kế đến là do giảm HDL-c chiếm $30 \%$ và thấp nhất là do tăng LDL-c $(12,2 \%)$.

Theo Daudén E (2013) tỷ lệ rối loạn lipid máu trên bệnh nhân vảy nến thay đổi theo từng nghiên cứu, dao động từ 6,4-50,9\%. Theo Wu Y. và cS (2008) tiến hành nghiên cứu trên 1.127 bệnh nhân vảy nến và 1.127 người nhóm chứng cho thấy tỷ lệ đái tháo đường, tăng huyết áp, tăng lipid máu ở bệnh vảy nến có tỷ lệ các yếu tố nguy cơ tim mạch và những bệnh lý khác cao hơn so với người không bệnh vảy nến nhân vảy nến cao hơn nhóm chứng. Với kết quả của nghiên cứu lớn này, các tác giả khẳng định bệnh nhân vảy nến có tỷ lệ các yếu tố nguy cơ tim mạch và những bệnh lý khác cao hơn so với người không bệnh vảy nến [5]. Một nghiên cứu khác của Salihbegovic EM (2015) trên 70 bệnh nhân vảy nến người Bosnia và Herzegovina cũ̉ng cho tỷ lệ rối loan lipid máu là $62,9 \%$. Nghiên cứu nói trên có tỷ lệ rối loạn lipid máu xấp xỉ với tỷ lệ trong nghiên cứu của chúng tôi (60\%).

Tuy nhiên, một nghiên cứu cắt ngang của Jamil A (2014) trên 120 bệnh nhân vảy nến người Pakistan lại cho thấy tỷ lê rối loạn lipid máu thấp hơn là $55,8 \%$. Nói chung viêc so sánh tỷ lệ rối loạn lipid máu trên bệnh nhân vảy nến giữa các nghiên cứu chỉ mang tính tương đối vì tiêu chuẩn định nghĩa rối loạn lipid máu không thống nhất giữa các tác giả, cũng như khác biệt về chủng tộc, tập quán ăn uống [6].

Về các yếu tố liên quan, chúng tôi chưa tìm ra được sự khác biệt mang ý nghĩa thống kê giữa các nhóm đối tượng phân theo tuổi, giới, hoat động thể lực, thói quen hút thuốc, rượu bia, chế độ ăn hay BMI. Các yếu tố lâm sàng liên quan đến vảy nến khác như tuổi khởi phát, thời gian mắc bệnh, tiền sử gia đình, thể lâm sàng hay mức độ nặng của bệnh phân theo BSA và PASI cũng không cho thấy làm thay đổi tỷ lệ rối loạn lipid máu của bệnh nhân. Do đó, vân chưa thể đưa ra được một dự đoán về các lý do có thể góp phần gây tăng nặng hơn sự rối loạn lipid máu trên bệnh nhân vảy nến.

\section{KẾT LUÂN}

- Các đối tượng nghiên cứu có độ tuổi khởi phát trung bình là 37,81 . Trong các thể lâm sàng: vảy nến thông thường chiếm tỷ lệ cao nhất, các thể còn lại lần lượt là vảy nến đỏ da toàn thân, vảy nến mủ, viêm khớp vảy nến. Vị trí thương tổn: chi trên, ở thân mình, chi dưới, vùng da đâu. Trung bình BSA là 28,64, nhóm BSA nặng có tỷ lệ cao nhất. Tính theo chỉ số PASI: đa số có độ nặng trung bình.

- Tỷ lệ bệnh nhân vảy nến có rối loạn lipid máu là $60 \%$, trong đó: tăng TG chiếm tỉ lệ cao nhất, kế đến là giảm HDL-c, tăng Cholesterol TP và tăng $L D L-c$. Chưa tìm được yếu tố liên quan làm ảnh hưởng đến tỷ lệ rối loạn lipid máu của bệnh nhân.

\section{TÀI LIÊU THAM KHẢO}

1. Nguyễn Trọng Hào \& Trân Hậu Khang (2016), "Nghiên cứu rối loan lipid máu trên bệnh nhân vảy nến", Tap chí Y học Thực hành, số 11/2013̆, trang 30-31.

2. Lê Minh Phúc Nguyến Tất Thắng (2012) "Nồng độ lipid máu trên bệnh nhân vảy nến tại bệnh viện Da Liễu Thành phố Hồ Chí Minh", Tạp chí Y học TP Hồ Chí Minh, 16(1), 260-268.

3. Lê Ngọc Diệp Trương Thị Mộng Thường (2012), "Chất lượng cuốc sống của bênh nhân vảy nến đến điều trị tại bệnh viện Da Liểu TP.HCM từ 01/9/2010 đến 30/4/2011", Tap chí Y học TP. Hồ Chí Minh, tập 16(phụ bản số 1), tr 284-292.

4. Trương Lê Anh Tuấn và Lê Ngọc Diệp (2012), "Mối liên quan giữa bệnh vảy nến và hội chứng chuyển hóa", 268-274. 
5. Daudén E, Castañeda S \& Suárez C et al (2013), "Clinical practice guideline for an integrated approach to comorbidity in patients with psoriasis", J Eur Acad Dermatol Venereol, 27, 1387-1404.

6. Evaluation Expert Panel on Detection, and Treatment of High Blood Cholesterol in Adults (Adult Treatment Panel III) (2002), "Third Report of the National Cholesterol Education Program (NCEP) Expert Panel on Detection, Evaluation, and
Treatment of High Blood Cholesterol in Adults (Adult Treatment Panel III) final report", Circulation, 106(3143-3421

7. Garshick MK \& Kimball AB (2015), " Psoriasis and the life cycle of persistent life effects", Dermatol Clin; 3, 25-39.

8. Grozdev I, Korman N \& Tsankov N (2014), "Psoriasis as a systemic disease", Clinics in Dermatology, 32, 343-350.

\title{
ĐÁNH GIÁ KẾT QUẢ CHUYỂN THẦN KINH XI CHO THẦN KINH TRÊN VAI TRONG ĐIỀU TRI LIÊTT ĐÁM RỐI CÁNH TAY Ở NGƯỜII LỚN
}

\author{
Đào Văn Giang*, Trần Thị Thanh Huyền*, Nguyễn Hồng Hà*
}

\section{TÓM TẮT}

Mục tiêu: Phẫu thuật chuyển thần kinh XI cho thần kinh trên vai để phục hồi chức năng của vai. Đối tượng và phương pháp: Nghiên cứu được thực hiện trên 62 bệnh nhân bị liệt ĐRTKCT được chuyển thần kinh XI cho thần kinh trền vai tai Bênh viên Viêt Đức trong thời gian từ 1/2016 đến 12/2020. Phương pháp nghiên cứu hồi cứu, mô tả cắt ngang. Kết quả: 62 bệnh nhân trong đó tỉ lệ nam/nữ: 61/1, tuổi từ 1856 tưổi, trung bình $27,5 \pm 7,9$ tuổi. Nguyên nhân chủ yễu do tại nạn giao thông $(90,3 \%)$. Thời điểm phẫu thuật chủ yếu là trước 6 tháng. Kết quả phục hồi dạng vai rất tốt ở 6,67\% các trường hợp, phục hồi dạng vai $30-120$ độ đạt $86,67 \%$. Phục hồi xoay ngoài của vai đạt $51,12 \%$. Kết luận: Việc chuyển thần kinh XI cho thần kinh trên vai nhằm phục hồi động tác dang vai và xoay ngoàilà một lựa chọn hữu ích và có giá trị trong điều trị liệt đám rối thần kinh cánh tay

Từ khóa: Liệt đám rối thần kinh cánh tay, thần kinh XI, trên vai

\section{SUMMARY}

ACCESSORY NERVE TRANSFER TO SUPRASCAPULARIS NERVE FOR RECONSTRUCTION OF SHOULDER FUNCTION

Purpose: Accessory nerve transfer to suprascapularis nerve for reconstruction of shoulder fuction. Material and method: 62 patients with traumatic brachial plexus injuries underwent surgical reconstruction with accessory to suprascapular nerve transfers. Method study is retrospective, cross-section study. Results: 62 patients, ratio male/female: 61/1, range of age from 18 to 56 years old. Average of age is $27,5+/-7,9$ years. The waiting time before surgery 6 monthsis the most common. Abduction shoulder recovery $>120$ degree was $6,67 \%$, from $30-120$ was $86,67 \%$. Recovered active external rotation of over 30 degree was $51,12 \%$. Conclusion: In brachial plexus

*Bênh viên Hữu nghi Việt Đức

Chịu trách nhiệm chính: Đào Văn Giang

Email: dr.dzang@gmail.com

Ngày nhận bài: $27 / 6 / 2021$

Ngày phản biên khoa học: $2 / 8 / 2021$

Ngày duyệt bài: $22 / 8 / 2021$ injury, using the spinal accessory nerve for transfer to the suprascapular nerve is reliable and provides some recovery of abduction for a large majority of patients.

Keywords: Spinal accessory nerve; brachial plexus; nerve transfer; nerve grafting; suprascapular nerve.

\section{I. ĐĂTT VẤN ĐỀ}

Tổn thương đám rối thần kinh cánh tay (ĐRCT) do chấn thương khá thường gặp, gây ra tình trạng tổn thương chức năng nghiêm trọng và hay gặp ở người trong độ tuổi lao động. Việc điều trị chấn thương đám rối thần kinh cánh tay cần phối hợp của nhiều kĩ thuật từ giai đoạn can thiệp về phẩu thuật thần kinh, giai đoạn chuyển gân, chuyển cơ, đóng cứng các khớp [4]. Phẫu thuật tái tạo lại chức năng của vai là ưu tiên hàng đầu ở những bệnh nhân tổn thương toàn bộ đám rối thần kinh cánh tay. Cách tiếp cận phổ biến nhất để tái tạo lại chức năng của vai là chuyển thần kinh XI (thần kinh phụ) cho thần kinh trên vai. Trên thế giới - nhìn lại y văn và lịch sử về chuyển thần kinh điều trị tổn thương ĐRCT được phát triển từ năm 1994, tác giả Oberlin và cộng sự lần đầu tiên đề xuất phương pháp chuyển một phần TK trụ cho TK cơ nhị đầu để làm gấp khuỷu (Oberlin I). Năm 2003, Leechavengvongs và cs thực hiện chuyển nhánh TK đầu dài cơ tam đầu cho nhánh trước TK mũ, đồng thời chuyển TK XI cho TK trên vai để phuc hồi dạng và xoay ngoài khớp vai. [6]. Tại Việt Nam, 2005 tác giả Võ Văn Châu đã thực hiện chuyển thần kinh XI cho thần kinh cơ bì qua đoạn ghép thần kinh hiển cho 57 bệnh nhân [1]. Nguyễn Việt Tiến [2], tác giả thực hiện phẫu thuật chuyển ghép TK từ rễ C7 bên đối diện cho TK cơ bì và TK giữa qua đoạn ghép là TK trụ gập đôi, có nối mạch nuôi để điều trị tổn thương hoàn toàn $Đ R C T, \ldots$

Tại Bệnh viện Việt Đức, trong những năm gần đây đã ứng dụng kỹ̃ thuật vi phẫu trong điều trị liệt đám rối thần kinh cánh tay. Trong đó có 
phẫu thuật chuyển thần kinh XI cho thần kinh trên vai được thực hiện thường quinhằm phục hồi động tác dạng vai và xoay vai. Tuy nhiên, vẫn chưa báo cáo nào tổng kết đánh giá về kĩ thuật này. Để có một góc nhìn sâu sắc và khẳng định hơn trong điều trị liệt ĐRCT chúng tôi thực hiện nghiên cứu: "Đánh giá kết quả chuyển thần kinh XI cho thần kinh trên vai trong điêu trị liệt đám rối thần kinh cánh tay người lớn" với mục tiêu: Đánh giá kêtt quả chuyển thần kinh XI cho thần kinh trên vai ở bệnh nhân liệt đám rối thần kinh người lớn từ năm 2016-2020.

\section{II. ĐỐI TƯỢNG VÀ PHƯƠNG PHÁP NGHIÊN CỨU}

2.1. Đối tượng nghiên cứu. Đối tượng nghiên cứu là 62 bệnh nhân bị tổn thương nhổ hoăcc đút rễ TK từ C5- T1 của ĐRCT do chấn thương được phẫu thuâat, trong đó có thực hiện kĩ thuật chuyển thần kinh từ thần kinh XI cho thần kinh trên vai nhằm phục hồi động tác dạng vai và xoay ngoài vai tại Bệnh viện Hữu nghị Việt Đức trong thời gian từ 01/2016 đến 12/2020

2.2. Phương pháp nghiên cứu: Phương pháp nghiên cứu hồi cứu, mô tả cắt ngang.

\section{KẾT QUẢ NGHIÊN CỨU VÀ BÀN LUÂN}

3.1 Đặc điểm đối tượng nghiên cứu. Chúng tôi thực hiện nghiên cứu trên 62 bệnh nhân bị liệt đám rối thần kinh cánh tay, trong đó có tỉ lệ phân bố giới tính $\mathrm{Nam} / \mathrm{Nữ}=61 / 1$. Tuổi từ 18- 56 tuổi, trung bình là: $27,5 \pm 7,9$ tuổi

Nguyên nhân: Chủ yễu do tai nạn giao thông chiếm $56 / 62$ bệnh nhân $(90,3 \%$ ), chỉ có $3 / 62$ bệnh nhân $(4,9 \%)$ tai nạn lao động, 2/62 bệnh nhân $(3,2 \%)$ bị tai nạn bạo lực và $1 / 62$ bệnh nhân $(1,6 \%)$ tai nạn sinh hoạt.

Vekris $M$, nghiền cứu trền $67 \mathrm{BN}$ có độ tuổi trung bình là 24,6 tuổi, trong đó phần lớn là $B N$ nam (chiếm trên $90 \%$ ), nguyên nhân do tai nạn giao thông chiếm 90\% [7]. Trong một nghiên cứu trên $520 \mathrm{BN}$ bị tổn thương ĐRCT tác giả Songcharoen P.[6], trong đó 93,5\% nam, nguyên nhân do tai nan giao thông chiếm $82 \%$ và độ tuổi trung bình là 23 tuổi. Nghiên cứu của chúng tôi cũng có nhiều điểm tương tự như với các tác giả khác.

Thời điểm phẫu thuât: chúng tôi phân làm hai nhóm, nhóm phẫu thuật tại thời điểm trước 6 tháng sau tai nạn và nhóm phẫu thuật tại thời điểm sau khi bị tai nạn 6 tháng sau tai nạn, trong đó thời điểm phẫu thuât trung bình của chúng tôi là 4,3 tháng. Một trong những yếu tố làm ảnh hưởng đến kết quả chuyển thần kinh là tuổi của bệnh nhân, ở BN cao tuổi thì phục hồi kém hơn BN trẻ tuổi. Bênh nhân được mổ sớm thời điểm trước 6 tháng thì khả năng phục hồi tốt hơn nhóm đối tượng còn lại, nếu thời điểm phẫu thuật trên 12 tháng kể từ khi bị chấn thương thì nguy cơ không phục hồi hay phục hồi rất kém. Ray. W.Z [8]cho rằng tốt nhất nên phẫu thuât ở thời điểm từ 3 đến 6 tháng sau khi chấn thương và muộn nhất là 12 tháng. Trong nghiên cứu này của chúng tôi, đa số các bênh nhân được tiến hành phẫu thuật tương đối sớm chiếm 83,9\%.

$16,1 \%$

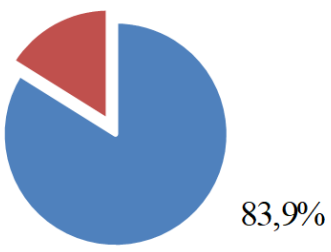

- Từ lúc chấn thương đến 6 tháng

- Trên 6 tháng

Biểu đồ 3.1. Thời điểm được phẫu thuật (tính từ lúc tai nạn)

\subsection{Kết quả sau phẫu thuât}

Bảng 3.1. Phục hối biên độ dạng vai sau phẫu thuật

\begin{tabular}{|c|c|c|c|c|c|c|}
\hline \multirow{3}{*}{$\begin{array}{c}\text { Mức dạng } \\
\text { vai }\end{array}$} & \multicolumn{6}{|c|}{ Sau phâu thuật } \\
\hline & \multicolumn{2}{|c|}{3 tháng $(n=62-4=58)$} & \multicolumn{2}{|c|}{6 tháng $(n=62-11=51)$} & \multicolumn{2}{|c|}{12 tháng $(n=45)$} \\
\hline & $\mathbf{n}$ & $\%$ & $\mathbf{n}$ & $\%$ & $\mathbf{n}$ & $\%$ \\
\hline <30 độ & 35 & 60,34 & 11 & 21,56 & 6 & 13,33 \\
\hline $30-60^{0}$ & 23 & 39,66 & 36 & 72,5 & 22 & 48,89 \\
\hline $61-90^{0}$ & 0 & 0 & 4 & 7,84 & 14 & 31,11 \\
\hline $90-120^{0}$ & 0 & 0 & 0 & 0 & 3 & 6,67 \\
\hline
\end{tabular}

Chúng tôi nhận thấy việc chuyển thần kinh từ XI cho thần kinh trên vai đã kích hoạt và tao dẫn truyền nhanh chóng, dễ dàng trong việc tập luyện các động tác vì tương đối sinh lí (nâng vai thành dạng vai), thể hiện ở đánh giá vào thời điểm 3 tháng sau mổ, có 39,66\% bệnh nhân có biểu hiện phục hồi dạng vai >30 độ. Các bệnh nhân không chỉ hồi phục lại về dạng vai mà còn điều chỉnh lại bán trật khớp vai nhờ sự tái sinh thần kinh của cơ trên gai.

Khi tác giả Jayme bắt đầu chuyển thần kinh XI cho thần kinh trên vai, với thất bại được xác 
định là dạng vai ít hơn 30 độ thì tỉ lệ thất bại chiếm $10 \%$ [3]. Tác giả khuyến nghị lấy ngưỡng dạng vai 30 độ để đánh giá thành công hay thất bại vì với mức dạng vai của biên độ này, ngưỡng sai khớp vai đã được điều chỉnh và bệnh nhân có thể vận động khớp vai. Chúng tôi nhận thấy trong nghiên cứu có những bệnh nhân không phục hồi dạng vai hơn 30 độ. Điều này có thể giải thích do tổn thương hai chố của thần kinh trên vai, tuy nhiên tỉ lệ này thấpMột lý do khác là tất cả bệnh nhân đều có cơ chế kéo căng khi bị chấn thương đám rối thần kinh cánh tay và có những tổn thương trên vi thể về cấu trúc sợi trục của cả nơi cho và nơi nhận thần kinh và chính điều này có thể làm kết quả hồi phục của một số bệnh nhân ở mức kém.

Kết quả chuyển dây TK XI cho trên vai trong các nghiên cứu có sự khác nhau. Trong một nghiên cứu bao gồm 21 bệnh nhân, Malessy và cộng sự đã quan sát thấy sự phục hồi của cơ trên gai và dưới gai ở $85 \%$ và $75 \%$ bệnh nhân, tương ứng thông qua kiểm tra điện chẩn cơ. Tuy nhiên, hoạt động giạng và xoay ngoài vai với sự co cơ $\geq 3$ tương ứng chỉ thấy ở $24 \%$ và $14 \%$ bệnh nhân. Ngược lại, Tersis và Cs đã quan sát thấy kết quả từ tốt đến xuất sắc của động tác dạng vai và xoay ngoài ở $79 \%$ và $55 \%$ bệnh nhân tương ứng. Kết quả tốt nhất đạt được khi phẫu thuật trong vòng 6 tháng sau chấn thương và không sử dụng đoạn ghép. Như vậy nếu so sánh thì kết quả của chúng tôi khi đánh giá động tác dạng vai thì gần với kết quả của Malessy hơon Tersis, còn khi đánh giá động tác xoay ngoài thì gần với nghiên cứu của Tersis và cộng sự hơn.

Bảng 3.2. Phục hồi biên độ xoay ngoài của khớp vai

\begin{tabular}{|c|c|c|c|c|c|c|}
\hline \multirow{3}{*}{$\begin{array}{c}\text { Mức xoay } \\
\text { ngoài }\end{array}$} & \multicolumn{6}{|c|}{ Sau phâu thuật } \\
\hline & \multicolumn{2}{|c|}{3 tháng $(n=62-4=58)$} & \multicolumn{2}{|c|}{6 tháng $(n=62-11=51)$} & \multicolumn{2}{|c|}{12 tháng $(n=45)$} \\
\hline & $\mathbf{n}$ & $\%$ & $\mathbf{n}$ & $\%$ & $\mathbf{n}$ & $\%$ \\
\hline$<30^{\circ}$ & 49 & 84,42 & 28 & 54,9 & 22 & 48,88 \\
\hline $30^{\circ}-<90^{\circ}$ & 9 & 15,51 & 23 & 45,1 & 18 & 40,00 \\
\hline $90^{\circ}-<120^{\circ}$ & 0 & 0 & 0 & 0 & 4 & 11,11 \\
\hline$>120$ & 0 & 0 & 0 & 0 & 1 & 2,22 \\
\hline
\end{tabular}

Đánh giá về phục hồi động tác xoay ngoài, sau 12 tháng, tỉ lệ phục hồi động tác xoay ngoài $>30$ độ chiếm tới $51,12 \%$. Chúng tôi cũng chưa có giải thích rõ ràng về sự phục hồi của động tác xoay ngoài. Không dùng các mảnh ghép thần kinh khi chuyển thần kinh và cần lưu ý chọn lọc đầu xa của thần kinh XI khoẻ tại vị trí gần với cơ nhất có thể làm tăng khả năng hồi phục của động tác xoay ngoài. Nghiên cứu đánh giá về chuyển thần kinh XI cho thần kinh trên vai ở bệnh nhân liệt toàn bộ đám rối thần kinh cánh tay của Jayme A.B. [3] cũng cho kết quả gân như vậy, ông cũng đưa ra giả thuyết về khả năng hồi phục kém của động tác xoay ngoài ở bệnh nhân liệt toàn bộ là (1) số lượng sợi trục myelin của thần kinh XI là không đủ tương thích với thần kinh trên vai (1300 và 3800$)$ nên phục hồi ở cơ trên gai nhiều hơn cơ dưới gai, (2) Cơ đối kháng - cơ dưới vai có vai trò trong sự ổn định của đầu xương cánh tay có thể bị tổn thương.

\section{KẾT LUÂ̂N}

Việc chuyển thần kinh $X I$ cho trên vai nhằm phục hồi động tác dạng vai và xoay ngoàilà một lựa chọn hữu ích và có giá trị trong điều trị liệt đám rối thần kinh cánh tay. Phẫu thuật này thực hiện đớn giản và tỉ lệ hồi phục cao. Việc được tiển hành phẫu thuật sớm sau khi có chẩn đoán xác định tổn thương đám rối thần kinh cánh tay giúp tăng khả năng hồi phục. Vì vâyy việc thăm khám, chẩn đoán và thực hiện phấu thuật sớm sau tổn thương là cần thiết và hết sức quan trọng.

\section{TÀI LIÊU THAM KHẢO}

1. Võ Văn Châu (2005), "Chuyển ghép thân kinh XI và thần kinh cơ bì để phục hồi gập khuỷu trong liệt đám rối thần kinh cánh tay", Thời sự Y dược học, 10(4) tr. 195-202.

2. Nguyên Việt Tiến, Nguyễn Viết Ngooc, Lê Văn Đoàn và cs (2011), "Kết quảchuyênrể thần kinh C7 từ bên lành trong điều trị nhổ các rễ thân kinh đám rối cánh tay", Tạp chí $Y$ dược học lâm sàng 108,6 , tr. 299-306.

3. Jayme A.B, et al (2016): "Results of spinal accessory to suprascapular nerve transfer in 110 patients with complete palsy of the brachial plexus" J Neurosurg Spine; Jun 24(6):990-5

4. Malessy MJA, de Ruiter GCW, de Boer KS, Thomeer RTWM (2004): "Evaluation of suprascapular nerve neurotization af- ter nerve graft or transfer in the treatment of brachial plexus traction lesions". J Neurosurg 101:377-389,

5. Ray W.Z., Chang J., Hawasli A., et al. (2016), "Motor Nerve Transfers: A Comprehensive Review", Journal of Neurosurgery, 78(1), pp. 1-26.

6. Songcharoen P., (1995), "Brachial plexus injury in Thailand: A report of 520 cases", Microsurgery, 16(1), pp. 35-39.

7. Vekris M.D., Beris A.E., Johnson E.O., et al, (2006), "Musculocutaneous neurotization to restore elbow flexion in brachial plexus paralysis", Microsurgery, 26(4), pp. 325-329. 


\section{NGHIÊN CỨU HÌNH THÁI TUẦ HOÀN BÀNG HỆ MẠCH VÀNH TRÊN CHỤP MACCH SỐ HÓA XÓA NỀN Ở BỂNH NHÂN TỔN THƯƠNG BA THÂN ĐộNG MACH VÀNH}

\section{TÓM TẮT}

Muc tiêu: Xác đinh tỷ lề và mức độ tuân hoàn bàng hệ (THBH) ở những bệnh nhân tổn thương ba thân động mạch vành (ĐMV). Đối tượng và phương pháp: Nghiên cứu hồi cứu mô tả cắt ngang 41 phim chup mach vành qua da ở những bênh nhân tổn thương 3 thân ĐMV từ tháng 7/2018- tháng 07/2019. Tại Trung tâm Can thiệp tim mạch - Bệnh viên Đai học Y Hà Nội. Kết quả: Trong 41 bệnh nhẩn tổn thương 3 thần ĐMV thì có $44,4 \%$ có $\mathrm{THBH}$ mạch vành. Tỉ lệ các mức độ THBH Rentrop 1 đến Rentrop 3 trong tổng số bệnh nhân nghiên cứu lần lượt là $14,6 \%, 24,4 \%$ và 4,9\%. Khi tắc động mạch gian thất trước thì chủ yếu găp tuần hoàn bàng hể kiểu $F$ (37.5\%). Khi tắc động mạch mũ thì chủ yếu gặp tuần hoàn bàng hệ kiểu $D(\dot{6} 6.7 \%)$. Khi tắc động mạch vành phải thì chủ yếu gặp tuần hoàn bàng hệ kiểu $A$ (60\%). Kết luâan: Tỉ lệ xuất hiện và mức độ tuần hoàn bàng hệ mạch vành theo thang điểm Rentrop và các kiểu tuân hoàn bàng hệ mạch vành theo phân loại của LeVin 1974.

Tứ khóa: Tổn thương ba thân ĐMV, chụp mạch vành qua da, THBH mạch vành

\section{SUMMARY}

RESEARCH ON THE CORONARY COLLATERAL CIRCULATION BY DIGITAL SUBTRACTION ANGIOGRAPHY OF PATIENTS WITH MULTI VESSEL CORONARY ARTERY DISEASE

Purpose: To determine the prevalence and the degree of coronary collaterals in patients with multivessel coronary artery disease. Subjects and methods: The retrospective cross-sectional description study was proceeded atCardiovascular Intervention Center, Hanoi Medical University Hospital from July 2018 to July 2019. A total of 41 patients with multi-vessel coronary artery disease were recruited to this study. Results: In this study, Coronary collateral circulation was graded Rentrop 1 in $14.6 \%$, Rentrop 2 in $24.4 \%$ and Rentrop 3 in $4.9 \%$ of these patients. In the left anterior descending obstruction, there are $37.5 \%$ type $\mathrm{F}$ collateral circulation. In the circumflex artery obstruction, there are $66,7 \%$ type D collateral circulation. In the Right coronary obstruction, there are $60 \%$ type A collateral circulation. Conclusion: The degree of collateral circulation assessed by the Rentrop score is a useful

*Trường Đại hơ Y Dước Thái Bình

Chịu trách nhiệm chính: Vũ Duy Tùng

Email: tunganatomy@gmail.com

Ngày nhận bài: 23/6/2021

Ngày phản biên khoa hoc: 1/8/2021

Ngày duyệt bài: 19/8/2021

\section{Vũ Duy Tùng*, Nguyễn Thị Tho**}

methods in the population with multi-vessel coronary artery disease, and pathways cororary collateral circulation by LeVin1974.

Keywords: Mutilvessel coronary artery disease, percutannenous coronary intervention, coronary collateral circulation.

\section{I. ĐĂT VẤN ĐỀ}

Tỷ lệ BN có tổn thương ba thân ĐMV ngày càng cao chiếm trên $40 \%$ tổn thương ĐMV [1]. Tổn thương ba thân ĐMV là tổn thương khi mức độ hẹp $\geq 50 \%$ cả ba nhánh ĐMV, trong đó ít nhất 1 mạch hẹp $\geq 70 \%$, tổn thương có ý nghĩa thân chung ĐMV trái (hẹp $\geq 50 \%$ ) kết hợp với tổn thương ĐMV phải (hẹp $\geq 70 \%$ ) [2]. Theo suy luận thông thường, khi tổn thương 3 thân động mạch vành thì tưới máu mô cơ tim giảm, biến đổi cấu trúc mô cơ tim, làm giảm sức co bóp tâm thất dẫn đến suy tim, biểu hiện trên siêu âm tim với chỉ số $\mathrm{EF}<50 \%$. Trên thực tế, khoảng $1 / 3$ tỷ lệ bệnh nhân bị tổn thương 3 thân động mạch vành không có bất thường cả về lâm sàng, điện tâm đồ và siêu âm tim (chức năng thất trái bình thường, EF > 50\%). Năm 1974, David $C$ và LeVin đã nghiên cứu mô tả các con đường tuần hoàn bàng hệ mạch vành theo từng động mạch thủ phạm. Năm 1986 Rentrop và Cohen tiến hành chụp ĐMV qua da cho 142 bênh nhân, ghi nhận 23 bệnh nhân có THBH động mạch vành được mô tả là những vòng nối tự nhiên được tạo nên bởi những mạch máu nối giữa các đoạn của cùng 1 động mạch vành hoặc giữa các đoạn của những động mạch vành khác nhau [3]. Sự phát triển của tuần hoàn bàng hệ như là nguồn cung cấp máu thay thế cho động mạch vành chi phối vùng cơ tim đó bị mất hoặc giảm chức năng cấp máu, tuần hoàn bàng hệ cũng là một phản ứng thích nghi với sự thiếu máu cơ tim cấp hoặc mạn tính và có vai trò như là một ống thông bắc cầu qua đoạn mạch vành bị hẹp [4], [5]. Chụp mạch vành qua da đã đánh giá chính xác mức độ hẹp ĐMV và sự phát triển của tuần hoàn bàng hệ mạch vành. Do đó, chúng tôi tiến hành nghiên cứu hình thái THBH mạch vành trên chụp mạch số hóa xóa nền ở bệnh nhân tổn thương ba thân ĐMV.

II. ĐỐI TƯỢNG VÀ PHƯƠNG PHÁP NGHIÊN CỨU

1. Đối tượng nghiên cứu: 41 phim chụp 
mạch vành qua da ở những bệnh nhân tổn thương 3 thân ĐMV từ tháng 07/2018- tháng 07/2019 tại Trung tâm Can thiệp tim mạch- Bệnh viện Đại học Y Hà Nội. Loại trừ phim không rõ nét, chồng lấn hình ảnh và $\mathrm{BN}$ đã được điều trị can thiệp mạch vành.

2. Phương pháp nghiên cứu: Nghiên cứu hồi cứu mô tả cắt ngang. Phần mềm SPSS 20.0.

\section{KẾT QUẢ NGHIÊN CứU}

1. Phân bố mức độ THBHMV ở mẫu nghiên cứu

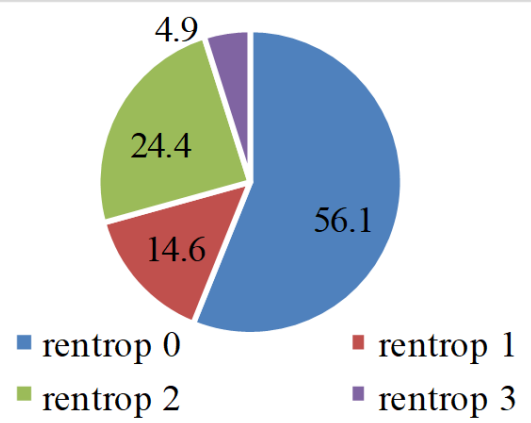

Biểu đồ 1. Phân bố mức độ tuần hoàn bàng hệ

Nhận xét: Trong 41 BN nghiên cứu có 23 BN không có THBH ứng với Rentrop0 chiếm 56,1\%. Có 18 bệnh nhân xuất hiện THBH mạch vành (43,9\%), trong đó mức độ THBH Rentrop1 chiếm 14,6\% (6 BN), Rentrop2 chiếm 24,4\% (10 BN) và Rentrop3 là $4,9 \%$ (2 $\mathrm{BN})$.

2. Phân bố bệnh nhân có THBHMV theo từng động mạch vành thủ phạm

2.1. Các kiểu THBHĐMV khi động mạch thủ phạm là động mạch gian thất trước

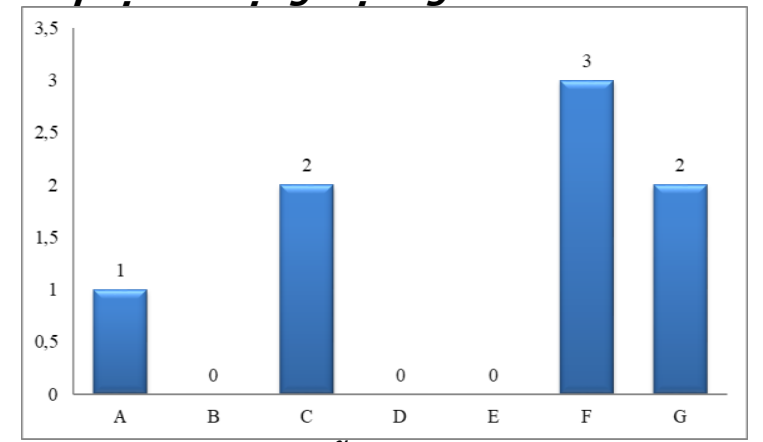

Biểu đồ 2.. Biểu diễn kiểu THBHMV khi ĐM thủ phạm là $Đ M$ gian thất trước

Nhận xét: Có 8 bệnh nhân có THBHMV khi động mạch thủ phạm là động mạch gian thất trước. Có 1 bệnh nhân (12.5\%) có THBHMV loại A, có 2 bệnh nhân (25\%) có THBHMV loại $C$, có 3 bệnh nhân $(37,5 \%)$ có THBHMV loại $F$, có 2 bệnh nhân $(25 \%)$ có THBHMV loại G. Loại THBHMV loại $B, D$, $E$ thì không có bệnh nhân nào.

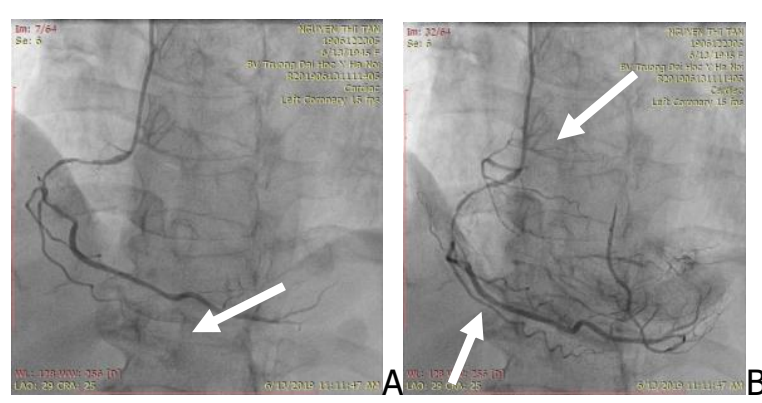

A. Khi thuốc cản quang chưa qua vòng nối

B. Thuốc cản quang qua vòng nối làm hiện ảnh 1 phần LAD

Hình 1. THBHMV kiểu $F$ (nôi từ ĐM PDA qua móm tới $L D A$ ) (BN Nguyễn Thị T - MS: 1906122305)

2.2. Kiểu THBHĐMV khi ĐM thủ phạm là động mạch mũ

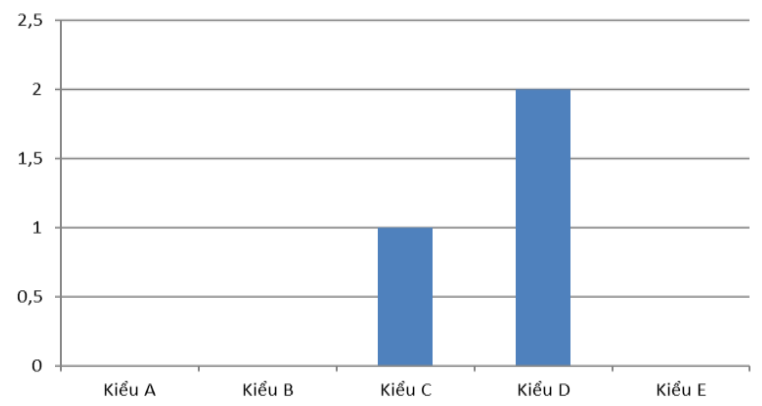

Biểu đồ 3. Biểu diễn kiểu THBHMV khi tăc ĐMM

Nhận xét: Nhóm động mạch vành thủ phạm là động mạch mũ có 3 bệnh nhân có THBHĐMV, trong đó có 1 bệnh nhân có THBHĐMV loại $C$, và 2 bệnh nhân có THBHĐMV loại $D$.

2.3. Kiểu THBHĐMV khi động mạch thủ phạm là động mạch vành phải

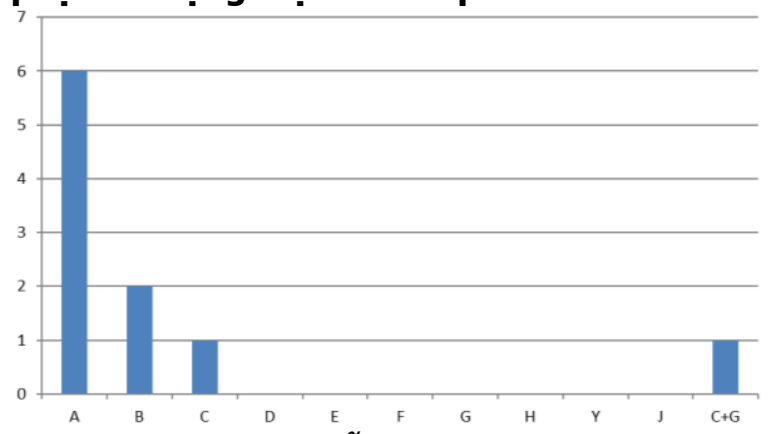

Biểu đồ 4. Biểu diễn kiểu THBHMV khi động mạch vành thủ phạm là ĐMV phải

Nhận xét: Nhóm động mạch vành thủ phạm là động mạch vành phải thì 10 bệnh nhân có THBHDMV. Trong đó cao nhất là THBHĐMV loại A với 6 bệnh nhân, THBHMV loại $B$ có 2 bệnh nhân. Trong nghiên cứu của chúng tôi xuất hiện 1 bệnh nhân phối hợp 2 loại THBHMV loại C và G. 


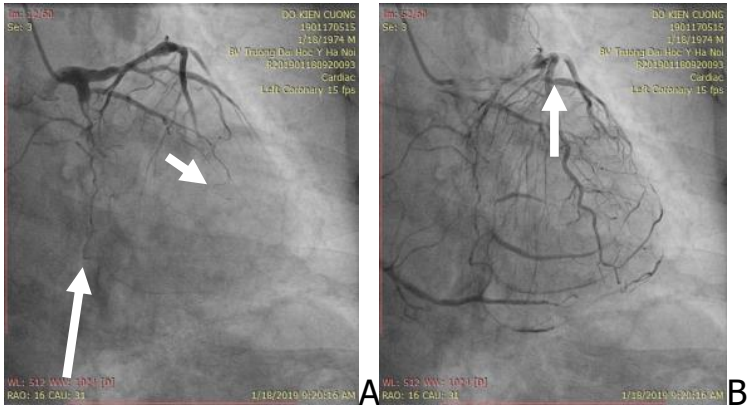

A. Khi thuốc cản quang chưa qua vòng nối

B. Thuốc cản quang qua vòng nối làm hiện ảnh 1 phần $L A D$

Hình 2. THBHMV kiêu $A$ (nôi từ các nhánh vách của LAD tới PDA) (BN Đố Kiên C - MS:1901170515)

\section{BÀN LUÂ̂N}

1. Phân bố mức độ tuân hoàn bàng hệ BN nghiên cứu. Trong 41 bệnh nhân nghiên cứu của chúng tôi, số bệnh nhân có tuần hoàn bàng hệ động mạch vành chiếm 43,9\%. Theo phân loại của Rentrop thì trong đó mức độ tuần hoàn bàng hệ Rentrop 1 chiếm 14,6\%, mức độ tuần hoàn bàng hệ Rentrop 2 có $24,4 \%$ và mức độ tuần hoàn bàng hệ Rentrop 3 là 4,9\%. Nhóm bểnh nhân có tuần hoàn bàng hệ tốt là nhóm những bệnh nhân có mức độ tuần hoàn bàng hệ Rentrop 2 và Rentrop 3 là 29,3\% tổng số 41 bệnh nhân bệnh nhân tổn thương ba thân ĐMV. Kết quả này cao hơn với kết quả $18,7 \%$ bệnh nhân có tuần hoàn bàng hệ tốt trong nghiên cứu của $A$. Kurtul và công sự năm 2017[6]. Kết quả này có thể được giải thích là do đối tượng bệnh nhân của chúng tôi lựa chọn là những bệnh nhân hẹp có ý nghĩa cả ba ĐMV, theo thời gian có sự thích nghi của cơ thể với tổn thương. Sự hình thành và phát triển tuần hoàn bàng hệ phụ thuộc vào mức độ hẹp của động mạch vành, thời gian thiếu máu và môt số yếu tố kích thích sự hình thành và phát triển của các tuân hoàn bàng hệ.

2. Về đặc điểm hình thái tuân hoàn bàng hệ động mạch vành. Trong nghiên cứu của chúng tối có 8 bệnh nhân có động mạch thủ phạm là động mạch gian thất trước. Khi phân tích các dạng THBH trên phim chụp DSA chúng tôi thu nhận được 4 dạng THBH mạch vành, bao gồm: Kiểu $A$, kiểu $C$, kiểu $F$, kiểu $G$. Khi tắc động mạch gian thất trước,chúng tôi quan sát thây hay gặp THBHMV kiểu $F$, các mạch máu nối từ động mạch gian thất sau qua mỏm tới động mạch gian thất trước. Kết quả này cũng phù hợp với giải phẫu kinh điển khi nghiên cứu về vòng nối động mạch vành, đây cũng là một trong những vòng nối tự nhiên của hệ động mạch vành.
Khi tắc động mạch vành phải thì hình thái tuần hoàn bàng hệ đa dạng (10 kiểu) hơn so với tắc động mạch gian thất trước và động mạch mũ. Điêu này có thể được giải thích do ưu thế đông mach vành phải chiếm $85 \%$, đông mạch cấp máu cho thất phải và $25-35 \%$ thất trái. Để bảo vệ cơ tim khi tắc động mạch vành phải thì các vòng nối phát triển phong phú hơn. Trong nghiên cứu của chúng tôi gặp chủ yếu tuần hoàn bàng hệ kiểu $A$ (THBHMV nối từ các nhánh vách của $L A D$ tới động mạch gian thất sau). Kết quả này có thể được giải thích do vị trí các nhánh vách của động mạch gian thất trước gần với các nhánh của động mạch gian thất sau qua vách gian thất để tưới máu cho mặt dưới của tim, bảo vệ cơ tim bảo tồn chức năng $\mathrm{EF}$ của thất trái.

Trong nghiên cứu của chúng tôi có 03 bệnh nhân có động mạch vành thủ phạm là động mạch mũ với 2 kiểu $T H B H$ là kiểu $C$ và kiểu $D$, trong đó tuần hoàn bàng hê kiểu $D$ chiếm ưu thế. Theo giải phẫu bình thường, các nhánh tân của động mạch mũ chạy vòng theo mặt sau của tim, góp phẩn tạo nên cấu trúc của nhánh gian thất sau và động mạch sau bên. Vì vây, khi tắc đông mach mũ sẽ xuất hiện cầu nối tự nhiên giữa nhánh tận của động mạch vành phải và các nhánh tận của động mạch mũ góp phần cấp máu thành sau bên thất trái để bảo tồn chức năng thất trái.

\section{KẾT LUÂNN}

Qua nghiên cứu của chúng tôi số bệnh nhân tổn thương ba thân ĐMV xuất hiện THBH là 18 bệnh nhân (43,9\%), trong đó mức độ THBH tốt Rentrop 2 và Rentrop 3 là 29,3\%. THBH xuất hiện nhiều hình thái khác nhau tùy theo động mạch thủ phạm. Khi tắc động mạch gian thất trước thì chủ yếu gặp tuần hoàn bàng hệ kiểu $\mathrm{F}$ (37.5\%). Khi tắc động mạch mũ thì chủ yếu gặp tuần hoàn bàng hệ kiểu $D(66.7 \%)$. Khi tắc động mạch vành phải thì chủ yếu gặp tuần hoàn bàng hệ kiểu $\mathrm{A}(60 \%)$.

\section{TÀI LIẸU THAM KHẢO}

1. Pham Thi Hồng Thi, Nguyễn Thi Loan (2016). Nghiên cứu đặc điểm tổn thương động mạch vành ở bệnh nhân tăng huyết áp bằng chụp cắt lớp vi tính đa dãy (256 dãy), Hội nghị Tím mạch toàn quốc.

2. Tsuiki K et all. (1991). Significant stenosis of coronary arteries in patients with single and multiple vessel diseases without previous myocardial infarction, Circulation. Vol 5, 427- 436.

3. M.D. MARC COHEN and K. P. RENTROP (1986). Limitation of myocardial ischemia by collateral circulation during sudden controlled coronary artery occlusion in human subjects: a 
prospective study. Circulation, 469-476

4. S. S. Fujita M, Ohno A, Nakajima H, Asanoi H. (1987). Importance of angina for development of collateral circulation. Br Heart J, 57, 139-143.

5. S. G. B. G (1987). Coronary circulation on normal and pathologic heart.
6. M. D. DAVID C. LEVIN (1974). Pathways and Functional Significance of the Coronary Collateral Circulation. Circulation, 50, 831-836

7. A. Kurtul v và S. Ozturk (2017). Prognostic value of coronary collaterals in patients with acute coronary syndromes. Coronary Artery Disease, 28, 406-412.

\section{BƯớC ĐẦU ĐÁNH GIÁ KẾT QUẢ CẤY MÁY TẠO NHİP VĨNH VIỄN HAI BUỒNG Ở' BỆNH NHÂN RỐI LOẠN NHİP TIM CHẬM TAI BẾNH VIẾN ĐA KHOA HÀ TĨNH}

\section{TÓM TẮT}

Mục tiêu: Đánh giá hiệu quả kỹ thuật cấy máy tạo nhịp tịm vĩnh viễn (MTNTVV) 2 buồng. Đoối tương và phương pháp nghiên cứu: Nghiên cứu thuần tập tiến cứu trên 47 Bệnh nhânđược chẩn đoán các bênh RLNT chậm có chỉ định cấy MTNNTVV hai buồng được tiền hành cấy máy hai buồng nhĩ tphair và thất phải dưới màn tăng sáng tại bệnh viện đa khoa tỉnh Hà Tĩnh từ tháng 7/2017 - 4/2019. Kết quả: 47 bệnh nhân với 30 nam và 17 nữ, tuổi trung bình $61,4 \pm$ 11 9. Các bệnh lý chỉ định cấy máy tạo nhịp tim vĩnh viễn 2 buồng: Block nhî̃ thất cấp 2, cấp 3 chiếm tî lệ 42,6\%; hội chứng suy nút xoang chiếm tỉ lệ $57,5 \%$. Ngưỡng kích thích trung bình của điện cực tiểu nhî phải $0,9 \pm 0,2 \mathrm{~V}$; của điện cực thất phải $0,5 \pm 0,2 \mathrm{~V}$. Phân suất tống máu thất trái EF sau cấy máy 3 tháng trung bình đo được là $57,3 \pm 8,5$. Không có bệnh nhân nào có biến chứng như tràn máu màng ngoài tim, nhiễm trùng túi máy, sút dây điện cực. Kểt luận: Kỹ thuật cây MTNTVV 2 buồng là một phương pháp an toàn, hiệu quả, với tỉ lệ thành công cao vàbiến chứng thấp. Khi thực hiên thành công ở tuyến tỉnh, góp phânn giảm tải cho các bệnh viện ở tuyến trên.

Tư khóa: Cấy máy tạo nhịp vĩnh viễn 2 buồng, rối loạn nhịp tim chậm

\section{SUMMARY \\ EVALUATING THE EFFICIENCY OF TWO- CHAMBER IMPLANTATION OF A \\ PERMANENT PACEMAKER AT HA TINH POLYCLINICAL HOSPITAL}

Objective: Evaluate the efficiency of two-chamber implantation of a permanent pacemaker (MTNTVV). Subjects and methods: A prospective cohort study on 47 Patients diagnosed with delayed RLP with indication of two-chamber MTNTVV implantation underwent two-chamber atrial and right ventricular implantation under the light screen in the disease.

*Bệnh viện Đa khoa tỉnh Hà Tïnh

Chịu trách nhiệm chính: Lê Văn Dũng

Email: dungtmht@gmail.com

Ngày nhận bài: 29/6/2021

Ngày phản biện khoa học; 25/7/2021

Ngày duyệt bài: 20/8/2021
General Hospital of Ha Tinh province from July 2017 to April 2019. Results: 47 patients with 30 men and 17 women, mean age $61.4 \pm 11.9$. Pathologies indicated to implant 2-chamber permanent pacemaker: level 2 and 3 atrioventricular block accounted for $42.6 \%$; Sinus node failure syndrome accounted for $57.5 \%$. The mean excitation threshold of the right atrial electrode should be $0.9 \pm 0.2 \mathrm{~V}$; of right ventricular electrode $0.5 \pm 0.2 \mathrm{~V}$. The mean left ventricular ejection fraction EF after 3 months of implantation was measured to be $57.3 \pm 8.5$. None of the patients had complications such as pericardial hemorrhage, pocket infection, and electrode failure. Conclusion: The 2-chamber MTNTVV culture technique is a safe, effective method, with a high success rate and low complications. When it is implemented successfully at the provincial level, it will help reduce the load on hospitals at higher levels.

Keywords: Two-chamber implantation of a permanent pacemaker, RLP

\section{I. ĐĂT VẤN ĐỀ}

RLNT chậm là một bệnh lý thường gặp trên lâm sàng, bệnh thường gây ra các biến chứng nặng nề như choáng, ngất, thậm chí đột tử cho người bệnh. Điêuu trị nội khoa bằng các thuốc tăng nhịp tim gân như không có hiệu quả và còn để lại nhiều tác dụng không mong muốn. MTNTVV là giải pháp hàng đâu hiện nay, mang tính hiệu quả và lâu dài để điều trị các RLNT chậm không hồi phục. Nhiêu nghiên cứu cho thấy đến nay MTNTVV không chỉ điêu trị triệu chứng, mà còn cải thiện chất lượng cuộc sống và cải thiện tỉ lệ sống còn cho bệnh nhân, đặc biệt là MTNTVV 2 buồng.

Tại Việt Nam kỹ thuật cấy MTNTVV đã được thực hiện ở nhiêu bệnh viện trên toàn quốc. Khoa Tim mạch-Bệnh viện đa khoa tỉnh Hà Tĩnh đã triển khai cấy MTNTVV 1 buồng từ năm 2013, từ năm 2016 đến nay cây máy 2 buông và đi vào hoạt động thường quy, trung bình mỗi năm từ 50 - 70 máy. Xuất phát từ thực tễ đó, chúng tôi tiến hành nghiên cứu đề tài này với mục tiêu: 
"Khảo sát đăc điểm lâm sàng, cân lâm sàng của bệnh nhân RLNT chậm có chi định cây MTNTVV 2 buồng và đánh giá hiệu quả kỹ thuật cây MTNTVV 2 buồng".

\section{II. ĐỐI TƯỢNG VÀ PHƯƠNG PHÁP NGHIÊN CỨU}

2.1. Thiết kế nghiên cứu: Nghiên cứu thuần tập tiến cứu

\section{2. Đối tượng nghiên cứu:}

Tiêu chuẩn lựa chọn. Đối tượng nghiên cứu là những bệnh nhân được chẩn đoán RLNT chậm có chỉ định cấy MTNTVV 2 buồng tại khoa Tim mạch - Bệnh viện đa khoa tỉnh Hà Tình từ tháng 7/2017 đển tháng 4/2019. Tiêu chuẩn chẩn đoán RLNT chậm và chỉ định cấy MTNTVV dựa theo khuyến cáo của Hội Tim Mạch Việt Nam và các Hội Tim Mạch Hoa Kỳ, Hội Tim Mạch Châu Âu. Các đối tượng được lựa chọn tuần tự theo thời gian không phân biệt lứa tuổi, giới tính.

Tiêu chuẩn loại trừ. Bệnh nhân không theo dõi, khám lại định kỳ sau khi cãy máy tạo nhịp tim vĩnh viễn. Bệnh nhân không đồng ý tham gia vào nghiên cứu.

2.3. Các bước tiến hành nghiên cứu: Hỏi bênh và khám lâm sàng đầy đủ khi vào viên, đăc biệt là các dấu hiệu do nhịp châm gây ra: Choáng, xiu, ngất, hoa mắt chóng mặt...

Làm đây đủ các xét nghiêm: Điên giải đồ, chức năng gan, thận, siêu âm tim, ĐTĐ và Holter ĐTĐ...

Giải thích cho gia đình và bệnh nhân về thủ thuât sắp thực hiên.

Kháng sinh dự phòng trước thủ thuật.

Tiến hành thủ thuật cấy máy tạo nhịp tim vĩnh viễn 2 buồng dưới da.

Bệnh nhân được điều trị nội khoa theo phác đồ trước, trong và sau phẫu thuật, kháng sinh dự phòng trong 7 ngày sau cấy máy.

Bệnh nhân được theo dõi các biến chứng: tụ máu, nhiễm trùng, tràn khí màng phổi, máy mất dẫn,...

Khám và theo dõi bệnh nhân sau 3 tháng khám định kỳ, làm các xét nghiệm siêu âm tim, ĐTĐ khi bênh nhân tái khám.

2.4. Xử lý số liệu: Sử dụng phần mềm SPSS 16.0. Các biến định lượng được thể hiện dưới dạng trung bình và độ lệch chuẩn. Các biến định tính thể hiện dưới dạng tỉ lệ phần trăm.

\section{KẾT QUẢ NGHIÊN CỨU}

Trong thời gian từ 7/2017 đến 4/2019, chúng tôi đã tiến hành nghiên cứu trên 47 bệnh nhân được chẩn đoán các rối loạn nhịp tim chậm và cấy máy tạo nhịp tim vĩnh viễn 2 buồng tại khoa Tim mạch -Bệnh viện đa khoa tỉnh Hà Tĩnh.

3.1. Đặc điểm chung. Độ tuổi trung bình trong nghiên cứu là $61,4 \pm 11,9$, trong đó bệnh nhân nhiều tuổi nhất là 94 tuổi, bệnh nhân ít tuổi nhất là 45 tuổi.

Trong nghiên cứu của chúng tôi có 30 bênh nhân nam, chiếm 63,8\%. Nữ giới có 17 bệnh nhân chiếm $36,2 \%$.

3.2. Đặc điểm lâm sàng và cận lâm sàng

Bảng 1. Phân bố chi định cây máy tạo nhịp tim vĩnh viễn 2 buồng

\begin{tabular}{|c|c|c|}
\hline Chỉ định cây máy & $\begin{array}{c}\text { Số lượng } \\
\text { bệnh nhânn }\end{array}$ & Tỉ lệ \% \\
\hline Block nhĩ - thất & 20 & $42,6 \%$ \\
\hline Hội chứng suyy nút xoang & 27 & $57,4 \%$ \\
\hline Tống & $\mathbf{4 7}$ & $\mathbf{1 0 0} \%$ \\
\hline
\end{tabular}

Bảng 2. Phân bố các lý do nhập viện

\begin{tabular}{|c|c|c|}
\hline $\begin{array}{c}\text { Triệu chứng lâm } \\
\text { sàng }\end{array}$ & $\begin{array}{c}\text { Số lượng } \\
\text { bệnh nhân }\end{array}$ & $\begin{array}{c}\text { Tỉ lệ } \\
\text { \% }\end{array}$ \\
\hline Chóng mặt & 21 & $44,7 \%$ \\
\hline Hồi hộp, tức ngực & 19 & $40,4 \%$ \\
\hline Ngất, xỉu & 7 & $14,9 \%$ \\
\hline Tống & $\mathbf{4 7}$ & $\mathbf{1 0 0 \%}$ \\
\hline
\end{tabular}

100

$74,5 \%$

0

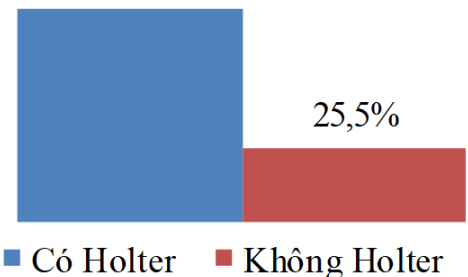

Biểu đồ 1. Tỉ lệ cây máy tạo nhịp dựa trên kết quả Holter DTE 24 giờ

3.3. Các thông số điện cực máy tạo nhịp tim vĩnh viến

Bảng 3. Các thông số cấy máy tạo nhịp tim vĩnh viến 2 buồng

\begin{tabular}{|c|c|c|c|}
\hline Các thông số & $\begin{array}{c}\text { Đơn vị } \\
\text { đo }\end{array}$ & $\begin{array}{c}\text { Điện cực } \\
\text { nhî̉ phải }\end{array}$ & $\begin{array}{c}\text { Điệ̂n cực } \\
\text { thất phải }\end{array}$ \\
\hline $\begin{array}{c}\text { Ngưỡng kích } \\
\text { thích trung bình }\end{array}$ & $\begin{array}{c}\mathrm{V} \\
(\mathrm{Vôn})\end{array}$ & $0,9 \pm 0,4$ & $0,5 \pm 0,2$ \\
\hline $\begin{array}{c}\text { Biên đô̂ sóng } \mathrm{P} / \\
\text { sóng R trung } \\
\text { bình }\end{array}$ & $\begin{array}{c}\mathrm{mV} \\
\text { (mili } \\
\text { vôn) }\end{array}$ & $2,1 \pm 1,1$ & $9,2 \pm 3,8$ \\
\hline $\begin{array}{c}\text { Trở kháng trung } \\
\text { bình }\end{array}$ & $\begin{array}{c}\Omega \\
(\mathrm{Ohm})\end{array}$ & $768 \pm 176$ & $657 \pm 135$ \\
\hline
\end{tabular}

3.4. Đặc điếm chức năng tim trước và sau cây máy

Bảng 4. Phân suất tống máu EF trung bình trước và sau cấy máy

\begin{tabular}{|c|c|c|c|}
\hline & $\begin{array}{c}\text { Trước cây } \\
\text { máy }\end{array}$ & $\begin{array}{c}\text { Sau cây máy } \\
\mathbf{3} \text { tháng }\end{array}$ & $\mathbf{P}$ \\
\hline $\begin{array}{c}\text { Phân suất } \\
\text { tống máu (EF) } \\
\text { trung bình }\end{array}$ & $62,7 \pm 9,8$ & $57,3 \pm 8,5$ & $\begin{array}{c}\mathrm{p}> \\
0,05\end{array}$ \\
\hline
\end{tabular}


3.5. Một số biến chứng sớm: Tất cả bệnh nhân được cấy máy tạo nhịp tim vĩnh viễn 2 buồng trong nghiên cứu của chúng tôi tại Bệnh viện đa khoa tỉnh Hà Tĩnh không có bệnh nhân nào bị biến chứng sớm như: máy mất dẫn, tụ máu bao máy, tràn khí màng phổi, tràn máu màng ngoài tim,...

\section{BÀN LUẬN}

4.1. Đặc điểm chung. Chúng tôi nghiên cứu trên 47 bểnh nhân, tuổi trung bình $61,4 \pm 11,9$ trong đó bệnh nhân nhiều tuổi nhất là 94 tuối, bệnh nhân ít tuổi nhất là 45 tuổi.Điều này chứng tỏ phần lớn bệnh nhân mắc các bệnh lý rối loạn nhịp tim chậm có tuổi đời khá cao. Độ tuổi này cũng tương tự với nhiều nghiên cứu khác ở trong nước cũng như ngoài nước. Tỉ lệ nam giới chiếm $63,8 \%$ trong khi đó tỉ lệ này ở nữ giới là $36,2 \%$. Sự khác biệt về tỉ lệ nam nữ mắc các bệnh RLNT nói chung đã được đề cập trong nhiều nghiên cứu, nhưng đến nay vẫn chưa sáng tỏ.

4.2. Triệu chứng lâm sang. Có 7 bệnh nhân trong nghiên cứu của chúng tôi vào viện vì xuất hiện ngất ít nhất 1 lần (chiếm 14,9\%). Qua đó chúng ta có thể thây nhiều bệnh nhân có tình trạng bệnh cảnh khá nặng nề, chờ đến lúc các triệu chứng diễn ra một cách trầm trọng, nguy hiểm đe dọa đến tính mạng mới nhập viện. Nghiên cứu của tác giả Huỳnh Trung Cang ở bệnh viện Kiên Giang thì tỉ lệ bệnh nhân ngất khá cao, chiếm $71 \%$. Các triệu chứng thường gặp khác như chóng mặt, choáng váng mă̆t mày và hồi hộp tức ngực, lần lượt chiếm tî lệ là $44,7 \%$ và $40,4 \%$.

4.3. Phấn bố bệnh lý cây MTNTVV 2 buồng. Trong nghiên cứu của chúng tôi thì bệnh nhân mắc các bệnh lý về Block nhĩ thất cấp 2 , cấp 3 chiếm tỉ lệ 42,6\%. Có 27 bệnh nhân được chẩn đoán hội chứng suy nút xoang, chiếm tỉ lệ $57,5 \%$. Đây là hai nhóm bệnh lý chính thường gặp trên lâm sàng trong chỉ định cấy máy tạo nhịp tim vĩnh viễn 2 buồng. Đặc biệt với sự phát triển của y học hiện đại, trong bệnh lý suy nút xoang, phương pháp cấy máy tạo nhịp 2 buồng dần thay thế tạo nhịp 1 buồng vì có nhiêu ưu điểm hơn cũng như có tiên lượng tốt hơn về chức năng tim sau này.

4.4. Tính hữu dụng của Holter điện tâm đồ 24 giờ. Có 35 bệnh nhân (chiếm 74,5\%) trong nghiên cứu của chúng tôi được chỉ định cấy máy tạo nhịp tim vĩnh viển 2 buồng dựa trên kết quả của Holter ĐTĐ 24 giờ. Những bệnh nhân này nhập viện với các tình trạng nhức đầu chóng mặt, một số khác có các triệu chứng hồi hộp tức ngực, cảm giác tim đập chậm nhưng hình ảnh điện tâm đồ bề mặt lại không phản ánh được đầy đủ tình trạng nhịp tim của bệnh nhân. Kết quả Holter ĐTÐ 24 giờ đóng vai trò rất quan trọng trong chẩn đoán các rối loạn nhịp tim chậm, là một phương pháp chẩn đoán hiệu quả và mang tính toàn diện qua đó cho các bác sĩ một cái nhìn tổng quát về tình trạng bệnh nhân.

4.5. Các thông số điện cực máy tạo nhịp tim vĩnh viễn 2 buồng. Ngưỡng kích thích của điện cực tiểu nhĩ phải trung bình trong nghiên cứu của chúng tôi là $0,9 \pm 0,2 \mathrm{~V}$. Kết quả này phù hợp với tiêu chuẩn tạo nhịp nhĩ được khuyến cáo là $0,4 \mathrm{~V}-1,4 \mathrm{~V}$. Biên độ sóng $\mathrm{P}$ trung bình đo được trong nghiên cứu là $2,1 \pm 1,1 \mathrm{mV}$. Trỏ kháng trung bình là $768 \pm 176 \Omega$.

Trong nghiên cứu của chúng tôi, 100\% bệnh nhân đạt tiêu chuẩn ngưỡng tạo nhịp thất theo khuyến cáo là $0,3 \mathrm{~V}-1,2 \mathrm{~V}$, trong đó ngưỡng kích thích điện cực thất phải trung bình của chúng tôi là $0,5 \pm 0,2 \mathrm{~V}$. Biên độ sóng $\mathrm{R}$ trung bình là 9,2 $\pm 3,8 \mathrm{mV}$. Trở kháng trung bình là $657 \pm 135 \Omega$. Điện cực thất phải được chúng tôi cố định ở 2 vị trí chính là vách liên thất và mỏm thất phải, và ở cả 2 vị trí này thì các thông số đo được đều thỏa mãn các tiêu chuẩn theo khuyến cáo đặt ra trước đây. Do vậy trong thực hành lâm sàng thì tùy từng tình trạng bệnh nhân cũng như tình trạng bệnh lý mà lựa chọn vị trí tạo nhịp thất phù hợp.

4.6. Đặc điểm về chức năng tim sau cây máy tạo nhịp tim vĩnh viễn 2 buồng. Chúng tôi theo dõi bệnh sau cấy máy tạo nhịp tim vĩnh viễn 2 buồng sau 3 tháng, bệnh nhân đến khám lại được làm các xét nghiệm điện tâm đồ, siêu âm tim. Phân suất tống máu thất trái EF sau cây máy 3 tháng trung bình đo được là $57,3 \pm 8,5$. Nhiêu nghiên cứu lâm sàng trên thế giới đã chỉ ra rằng việc cấy máy tạo nhịp tim vĩnh viễn 2 buồng mang lại lợi ích lâu dài hơn cho bệnh nhân, tránh được sự mất đồng bộ nhĩ thất, nhờ đó làm giảm được tỉ lệ suy tim hơn so với việc cấy máy tạo nhịp tim vĩnh viễn 1 buồng. Tuy nhiên vì điều kiện thời gian cũng như một số lí do khác nên chúng tôi chỉ theo dõi được các thông số này sau 3 tháng.

4.7. Biến chứng sau cây máy: Tất cả 47 bệnh nhân được cấy máy tạo nhịp tim vĩnh viễn 2 buồng trong nghiên cứu của chúng tôi tại Bênh viện đa khoa tỉnh Hà Tĩnh không có bệnh nhân nào bị biến chứng sớm như: máy mất dẫn, tụ máu bao máy, tràn khí màng phổi, tràn máu màng ngoài tim. Trong thời gian triển khai kỹ thuật này tại bệnh viện chúng tôi không có trường hợp bệnh nhân nào tử vong. 


\section{KẾT LUẬN}

Qua nghiên cứu 47 bệnh nhân tại bệnh viện đa khoa tỉnh Hà Tĩnh, chúng tôi nhận thấy kỹ thuật cấy MTNTVV 2 buồng bước đầu triển khai thành công, là một phương pháp điều trị an toàn, hiệu quả, ít nguy hiểm với tỉ lệ biến chứng thấp. Sự thành công này góp phần tiết kiệm thời gian và chi phí điều trị cho bệnh nhân, qua đó làm giảm tải cho các bệnh viện tuyến trên.

\section{TÀI LIÊU THAM KHẢO}

1. Prystonsky, E.N., Cardiac Arrhythmias. 1994

2. Parsonnet, V., et al., An intracardia bipolar electrode for interim treatment of complete heart block. Am J Cardiol, 1962. 10: p. 261-5.

3. Larsson, B., et al., Lessons from the first patient with an implanted pacemaker: 1958-2001. Pacing Clin Electrophysiol, 2003. 26(1 pt 1): p.114-24.
4. Nguyễn Mạnh Phan, et al., Khuyến cáo của Hội Tim Mạch học Việt Nam về chỉ định đặt máy tạo nhịp. K̇huyến cáo về các bệnh lý tim mạch và chuyển hóa, 2008: p.217-234.

5. Belott. PH. Implant Technique, Cardiac pacing for clinician Second Edition, Fred M. Kusumoto, 2008: p.116-255.

6. Nguyễn Sỹ Huyên, Trân Thống, Nguyễn Phú Du, Ta Tiến Phước, Máy tao nhip tim cơ bản thực hành, Tạp chí Tim mạch học Việt Nam số 16, 1998: p.60.

7. Pham Như Hùng, Trân Song Giang, Trân Văn Đồng, Tạ Tiến Phước, Thực trang câyy máy tạo nhịp tim vĩnh viễn 1 buồng và 2 buồng tim trong chỉ định nhip chậm tại Viện tim mạch Quốc gia Việt Nam. Kỷ yểu tóm tắt các báo cáo khoa học, Đại hội Tim mach toàn quốc lần thứ 13, 2012: p.19-20.

8. Trân Thhông, Tạo nhịp thất với máy 2 buồng: Lợi hay hại? Hội nghị Tim mạch miên nam, 2009.

\section{ĐIỆN Đồ TĨNH MẠCH PHỔI Ở BỆNH NHÂN RUNG NHĨ KỊCH PHÁT}

\section{Phan Đình Phong ${ }^{1}$, Bùi Văn Nhơnn, Trần Tuấn Việt ${ }^{1}$, Đỗ Mạnh Cầm ${ }^{1}$}

\section{TÓM TẮT}

Nghiên cứu được tiến hành với muc tiêu mô tả đăc điểm điện đồ tĩnh mạch phổi ở bệnh nhân rung nhî kịch phát tại Viện Tim mạch Việt Nam. Kết quá cho thấy, điện đồ tĩnh mạch phổi đều được ghi nhận ởbệnh nhân rung nhĩ kịch phát (chiếm 100\%). Khoảng thời gian dẫn truyền nhĩ - tĩnh mạch phổi (khoảng APV) tối đa và trung bình ở tĩnh mạch phổi trên trái là dài nhất $(67,00 \pm 9,72 \mathrm{~ms}$ và $56,65 \pm 8,52 \mathrm{~ms}$, tương ứng). Hình dạng điện đồ tĩnh mach phổi thường gặp là điện đồ nhiều thành phần $(31,6 \% \pm 8,7 \%)$; hình dạng điện đồ tĩnh mạch phổi khác bao gồm điện đồ 3 pha $(29,5 \% \pm 9,1 \%)$, điện đồ 2 pha $(19,4 \% \pm 8,4 \%)$ và điện đồ kép $(5,8 \% \pm 5,9 \%)$. Điện đồ kép gặp nhiêu nhất ở tĩnh mạch phổi trên trái $(11,9 \% \pm 6,8 \%)$.

Tư khoá: Rung nhĩ kịch phát, điện đồ tĩnh mạch phổi, điện đồ nhiều thành phần, điện đồ kép.

\section{SUMMARY \\ PULMONARY VEIN POTENTIALS IN \\ PATIENTS WITH PAROXYSMAL ATRIAL FIBRILLATION}

Objectives: To describe pulmonary vein (PV) potentials in patients with paroxysmal atrial fibrillation at the Vietnam Heart Institute. The results showed that typical PV potentials were recorded all patients

\footnotetext{
${ }^{1}$ Trường Đại học Y Hà Nội

${ }^{2}$ Bệnh viện Đại học Y Hà Nội

Chịu trách nhiệm chính: Bùi Văn Nhơn

Email: drbuinhon@hmu.edu.vn

Ngày nhận bài: 25/6/2021

Ngày phản biện khoa học: 25/7/2021

Ngày duyệt bài 15/8/2021
}

withparoxysmal atrial fibrillation(100\%). The maximal and mean A-PV intervals in left superior pulmonary vein were longest $(67.00 \pm 9.72 \mathrm{~ms}$ và $56.65 \pm 8.52$ $\mathrm{ms}$, respectively).Types of pulmonary vein potentials were a higher prevalence ofmultiphasic $(31.6 \% \pm$ $8.7 \%)$; the others were included triphasic potentials $(29,5 \% \pm 9,1 \%)$, biphasic potentials $(19,4 \% \pm 8,4 \%)$, and double potentials was $5.8 \% \pm 5.9 \%$. The double potentials was a highest in left superior pulmonary vein $(11.9 \% \pm 6.8 \%)$

\section{Keywords:}

Paroxysmal atrial fibrillation,pulmonary vein potentials, multiphasic potentials, double potentials.

\section{I. ĐĂT VẤN ĐỀ}

Rung nhĩ là rối loạn nhịp tim thường gặp, xảy ra ở 1-2\% dân số. Tỷ lệ mới mắc và hiện mắc rung nhĩ có xu hướng cao ở các nước phát triển [1]. Tỷ lệ rung nhĩ kịch phát ước tính chiếm 3\% ở người trên 20 tuổi; tỉ lệ tăng cao ở người lớn tuổi và những bệnh nhấn mắc các bệnh như tăng huyết áp, suy tim, bệnh động mạch vành, bệnh lý van tim, béo phì, đái tháo đường, bệnh thận mạn tính [1]. Trung bình tỷ lệ mắc mới của rung nhĩ khoảng $0,1 \%$ mỗi năm ở người dưới 40 tuổi, và tăng lên nhanh ở người trên 60 tuổi với 1,5-2,0\% [2]. Theo nghiên cứu Framingham, tỷ lệ hiên mắc rung nhĩ từ 0,5\% ở tuổi 50-59 tăng nhanh tới 8,8\% ở tuổi 80-89. Tỷ lệ mắc rung nhĩ kịch phát trong số rung nhĩ là cao: theo Godfredsen là 35,0\%, theo Takahashi là 40,2\%, theo Phillips là 62,0\%. Cùng với xu hướng gia tăng tỷ lệ mắc thì gánh nặng của rung nhĩ cũng 
tăng nhanh chóng [1]. Rung nhĩ có thể gây những biến chứng nặng nề.

Rung nhĩ làm tăng tỷ lệ suy tim và đột quy, là yếu tố nguy cơ độc lập của đột quy. và là nguyên nhân gây ra $18-25 \%$ nhồi máu não. Ở bệnh nhân đột quy, tỷ lệ rung nhĩ kịch phát được phát hiện rất cao với 36,0\% [3].

Tĩnh mạch phổi có vai trò trung tâm trong quá trình sinh lý bệnh của rung nhĩ. Nhiều nghiên cứu đã chỉ ra các ổ ngoại vị ở tĩnh mạch phổi có thể là trung tâm khởi phát gây ra rung nhĩ. Nguî̀n gốc chính của các ổ ngoại vị là do các bó/bè cơ tim nhĩ trái chạy sâu và lát trên bề mặt tĩnh mạch phổi. Các bó/bè cơ này bao gồm chủ yếu là các tế bào cơ rất giống với tế bào cơ nhĩ bình thường, và sự xuất hiện các tế bào cơ này thường nằm rải rác ở các bó/bè cơ tim trong tĩnh mạch phổi. Rung nhĩ kịch phát thường có nguồn gốc từ bó/bè cơ tim kéo dài trong tînh mạch phổi. Một số nghiên cứu cho thấy, tĩnh mạch phổi không chỉ hoạt động như ổ khởi phát rung nhĩ mà còn tham gia vào duy trì rung nhĩ [4]. Tác giả Wendel Moreira và cộng sự tiến hành nghiên cứu ở 70 bệnh nhân rung nhĩ kịch phát, kết quả đã phát hiện hầu hết các ổ khởi phát rung nhĩ là từ tĩnh mạch phổi. Hoạt động điện ở tĩnh mạch phổi trên trái được phát hiện ở 63 bệnh nhân chiếm tỷ lệ $90,0 \%$, ở tĩnh mạch phổi dưới trái là 52 bệnh nhân chiếm 74,3\%, ở tĩnh mạch phổi trên phải là 57 bệnh nhân chiếm $81,4 \%$ và ở tĩnh mạch phổi dưới phải là 16 bệnh nhân chiếm 22,9\% [5]. Hiểu biết chính xác về điện đồ của các tĩnh mạch phổi góp phần tăng hiệu quả triệt đốt rung nhĩ kịch phát thành công, đồng thời tránh được các biến chứng sau can thiệp như hẹp tĩnh mạch phổi sau thủ thuật, biến cố về huyết khối hoặc tổn thương dây thần kinh...

Tại Việt Nam, hiện nay chưa có nhiềunghiên cứu về đặc điểm điện đồ ở tĩnh mạch phổi, đặc biệt là ở bệnh nhân rung nhĩ kịch phát. Do đó, những hiểu biết về điện đồ ở tî̃nh mạch phổi ở bệnh nhân rung nhĩkịch phát ở Việt Nam còn rất khiêm tốn, làm ảnh hưởng đến hiệu quả điều trị ở bệnh lý này.Chính vì những lý do trên, nghiên cứu này được tiến hành với mục tiêu mô tả đặc điểm điện đồ tĩnh mạch phổi ởbệnh nhân rung nhĩ kịch phát tại Viện Tim mạch Việt Nam.

\section{II. ĐỐI TƯợNG VÀ PHƯƠNG PHÁP NGHIÊN CỨU}

1. Đối tượng nghiên cứu. Bệnh nhân được chẩn đoán xác định rung nhĩ kịch phátvà có chỉ định điều trị bằng năng lượng sóng có tần số radio theo khuyến cáo của Hội Tim mạch châu Âu (European Society of Cardiology - ESC). Bệnh nhân đồng ý tham gia nghiên cứu.

Tiêu chuẩn loại trừ: mắc bệnh lý van tim; huyết khối buồng tim; rối loạn chức năng tâm thu thất trái trung bình đến nặng $(<40 \%)$; bệnh lý cấp tính như nhiếm khuẩn cấp, tai biến mạch máu não mới, rối loạn đông máu, suy thận với mức lọc cầu thận <30 ml/phút; rung nhĩ thứ phát chưa kiểm soát được nguyên nhân như nhiễm độc, rối loạn chức nằng tuyến giáp.

\section{Phương pháp nghiên cứu}

2.1. Thiết kế nghiên cứu: mô tả cắt ngang tại Viện Tim mạch Việt Nam, Bệnh viện Bạch Mai. Thời gian nghiên cứu: từ tháng $8 / 2017$ đến tháng 9/2018.

\subsection{Mẫu nghiên cứu:}

* Cỡ mẫu nghiên cứu: nghiên cứu tiến hành ở 45 bệnh nhân.

*Chọn mẫu nghiên cứu: chọn mẫu toàn bộ. Bệnh nhân rung nhĩ kịch phát thỏa mãn các tiểu chuẩn chọn bệnh được lấy vào nghiên cứu liên tiếp theo trình tự thời gian.

2.3. Nội dung, biến sốnghiên cứu chính:

*Một số đặc trưng cá nhân: tuổi; giới tính (nam giới/nữ giới); cơn rung nhĩ: tần suất xuất hiện, thời gian mắc bệnh, điều kiện xuất hiện cợn, điều kiện kết thúc cơn.

\section{*Đặc điểm điện đồ tĩnh mạch phổi} (TMP) khi thăm dò bằng điện cực vòng

- Số lượng tĩnh mạch phổi có hoạt động điện (điện đồ).

+ Điện đồ tĩnh mạch phổi được định nghĩa là điện thể có tần số cao, có hình dạng sắc nét, thời gian $<50 \mathrm{~ms}$ và điện thế $>0,05 \mathrm{mV}$, và đi sau điện đồ cơ nhĩ [6], [7].Điện đồ tĩnh mạch phổi được xác định bằng sự biến mất của chúng sau khi tĩnh mạch phổi bị cô lập về điện học [6].

- Vị trí tĩnh mạch phổi có hoạt động điện thế: tĩnh mạch phổi trên trái, dưới trái, trên phải, dưới phải, tĩnh mạch phụ.

- Số cặp điện cực của điênn cực vòng (PV 1-2, $3-4,5-6,7-8,9-10)$ tại mối tĩnh mạch phổi có hoạt động điện.

- Thời gian dẫn truyền qua lỗ tĩnh mạch phổi: được xác định là khoảng thời gian giữa khởi đầu điện thế của tâm nhĩ (atrial deflection - A) đến điểm kết thúc điện thế tại tĩnh mạch phổi (PV potential - PV), được ký hiệu là khoảng A-PV (trong nghiên cứu không sử dụng điểm khởi đầu của điện thế tĩnh mạch phổi bởi vì khó xác định do điện thế phân mảnh hoặc liên tục)[8]. Khoảng A-PV được ghi trong khi nhịp xoang: tiến hành đo khoảng $A-P V$ tại mỗi cặp của điện cực vòng (PV 1-2, 3-4, 5-6, 7-8, 9-10) sau đó xác định giá trị trung bình và giá trị lớn nhất của 
khoảng A-PV tại mỗi tĩnh mạch phổi.

- Hình dạng điện đồ tĩnh mạch phổi: gồm điện thễ thẩp, điện thế 1 pha, 2 pha, 3 pha, nhiều thành phần và điện đồ kép [7],

\subsection{Quy trình nghiên cứu}

* Bệnh nhân được chụp cắt lớp vi tính đa dãy tĩnh mạch phổi (128 và 256 dãy) để đánh giá chính xác số lượng tĩnh mạch phổi.

*Tiến hành ghi điện đồ tĩnh mạch phổi tại phòng Cathlab

- Ghi điện đồ trước triệt đốt RF tại lỗ tĩnh mạch phổi bằng điện cực vòng lần lượt ở tĩnh mạch phổi trên trái, dưới trái, trên phải và dưới phải, và tĩnh mạch phổi phụ (nếu có), trong đó điện cực vòng 10 cực sẽ được đưa vào vị trí $5 \mathrm{~mm}$ của lỗ tĩnh mạch phổi. Điện đồ được ghi tại lỗ tĩnh mach phổi.
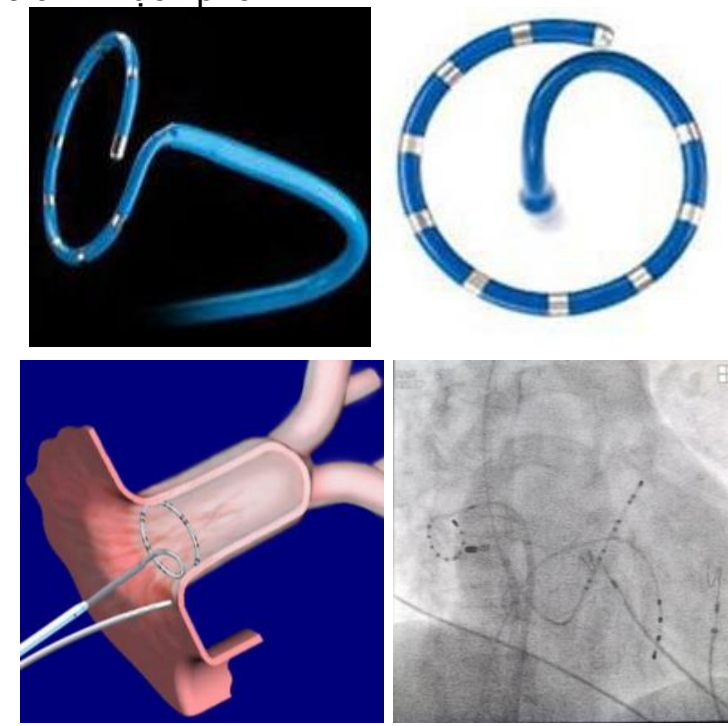

Hình 1. Hình ảnh điên cức vòng (điên cực Circular)

- Ở mỗi tĩnh mach phổi sẽ ghi nhận điện thế từ 5 cặp điện cực PV 1-2, 3-4, 5-6, 7-8, 9-10 của điện cực vòng. ở một số tĩnh mạch phổi phụ giữa phải không ghi được điện thế bởi vì ống thông không thể đưa được vào trong các lỗ TMP đó.

+ Đối với những trường hợp nhịp xoang (ngoài cơn rung nhĩ), điện thế ghi tại tînh mạch phổi khi nhịp xoang và ngay thời điểm tạo nhịp từ xoang vành với chu kỳ dài $600 \mathrm{~ms}$ hoặc 500 ms (cycle length) (tiến hành tạo nhịp từ xoang vành để xác định và phân biệt điện thế nhĩ và điện thế của tĩnh mạch phổi).

- Ghi điện đồ sau triệt đốt tại lỗ tĩnh mạch phổi bằng điện cực vòng: kiểm tra lần lượt ở tînnh mạch phổi trên trái, dưới trái, trên phải, dưới phải, tĩnh mạch phổi giữa phải.

+ Đối với những tînh mach phổi còn ghi được điện đồ nghi ngờ là điện đồ far-field đến từ tiểu nhĩ trái, thì tạo nhịp tại tiểu nhĩ trái. Nếu điện đồ thu được từ điện cực vòng đi sát với spike tạo nhịp thì đó là điện đồ far-field thu được trong tĩnh mạch phổi.

+ Tạo nhịp lần lượt từ PV 1-2 đến PV 9-10, nếu khổng thấy điện đồ dẫn ra nhĩ trái thì tĩnh mạch phổi đó đã bị cô lập hoàn toàn (Exit block).

2.4. Xử lý và phân tích số liệu: Số liệu được quản lý và phân tích trên phần mềm IBM SPSS 20.0.

2.5. Đạo đức nghiên cứu: Thực hiện theo đúng các quy định và hướng dẫn về đạo đức trong nghiên cứu y sinh học. Đối tượng nghiên cứu đã được thông báo về mục đích của nghiên cứu và hoàn toàn tự nguyện tham gia nghiên cứu.

\section{KẾT QUẢ NGHIÊN CỨU}

Bảng 1. Một số đặc trưng cá nhân của đôi tượng nghiên cứu

\begin{tabular}{|c|c|c|}
\hline Đặc trưng cá nhân & Số lượng & Tỷ lệ \% \\
\hline \multicolumn{3}{|c|}{ Giới tính } \\
\hline Nam giới & 33 & 73,3 \\
\hline Nữ giới & 12 & 26,7 \\
\hline \multicolumn{3}{|c|}{ Nhóm tuối } \\
\hline$<40$ tuối & 3 & 6,7 \\
\hline $40-49$ tuối & 8 & 17,8 \\
\hline $50-59$ tuối & 11 & 24,4 \\
\hline$\geq 60$ tuối & 23 & 51,1 \\
\hline Tuổi* & \multicolumn{2}{|c|}{$\begin{array}{l}\text { Trung vi: } 60 \text {, nhỏ nhất: } \\
26 \text {, Iớn nhất: } 75\end{array}$} \\
\hline Chiêu cao (m) & \multicolumn{2}{|c|}{$\begin{array}{c}\text { Trung bình } \pm \text { SD: } \\
1,64 \pm 0,08\end{array}$} \\
\hline Cân nặng (kg) & \multicolumn{2}{|c|}{$\begin{array}{l}\text { Trung bình } \pm \text { SD: } \\
62,20 \pm 10.04\end{array}$} \\
\hline \multicolumn{3}{|c|}{ BMI $\left(\mathbf{k g} / \mathbf{m}^{2}\right)$} \\
\hline Thiếu cân (BMI <18,5) & 1 & 2,2 \\
\hline $\begin{array}{c}\text { Bình thường } \\
(18,5 \leq \text { BMI }<23)\end{array}$ & 21 & 46,7 \\
\hline $\begin{array}{c}\text { Thừa cân } \\
(23 \leq \text { BMI }<25)\end{array}$ & 11 & 24,4 \\
\hline Béo phì $(B M I \geq 25)$ & 12 & 26,7 \\
\hline
\end{tabular}

*Phân bố không chuẩn. SD: độ lệch chuấn

Trong số 45 bệnh nhân tham gia nghiên cứu, nam giới chiếm tỷ lệ $73,3 \%$. Bệnh nhân $\geq 60$ tuổi chiếm tỷ lệ cao nhất $(51,1 \%)$; tuổi nhỏ nhất là 26 tuổi, lớn nhất là 75 tuổi.Thời gian phát hiện rung nhĩ có trung vị là 3,0 tháng, ngắn nhất là 1 tháng, dài nhất là 80 tháng. Số cơn rung nhĩ/tháng có trung vị là 4 cơn, ít nhất là 1 cơn và nhiêu nhất là 16 cơn. Trong đó $77,8 \%$ cơn rung nhĩ tự hết.

*Đặc điểm điện đồ tĩnh mạch phổi. Kết quả nghiên cứu cho thấy $80,0 \%$ bểnh nhân có 4 tînh mạch phổi có điện đồ. Trung bình tĩnh mạch phổi có điện đồ là $3,89 \pm 0,57$. 
Bảng 2. Tỷ lệ có điện đồ theo từng tĩnh mạch phôi $(n=45)$

\begin{tabular}{|c|c|c|}
\hline Điện đồ & $\begin{array}{c}\text { Số } \\
\text { lượng }\end{array}$ & $\begin{array}{c}\text { Tỷ lệ } \\
\text { \% }\end{array}$ \\
\hline TMP trên trái $(n=44)$ & 44 & 100 \\
\hline TMP dưới trái $(n=44)$ & 42 & 95,5 \\
\hline TMP trên phải $(n=45)$ & 43 & 95,6 \\
\hline TMP dưới phải $(n=45)$ & 42 & 93,3 \\
\hline Thân chung TMP trái $(n=1)$ & 1 & - \\
\hline
\end{tabular}

TMP giữa phải $(\mathrm{n}=3)^{*}$

*: Số lượng TMP giữa phải là 9, nhưng chỉ 3 trường hợp điện cực vòng đưa được vào trong tĩnh mạch phổi ghi điện đồ

Nhận xét: $100 \%$ bệnh nhân có điện đồ tại tĩnh mạch phổi (100\%). Tỷ lệ có điện đồ ởTMP trên trái là $100 \%$, dưới trái là $95,5 \%$, trên phải là $95,6 \%$ và dưới phải là 93,3\%.

Bảng 3. Khoảng A-PV tối đa và trung binh qua lỗ tĩnh mạch phổi

\begin{tabular}{|c|c|c|c|c|c|c|}
\hline Khoảng A-PV & Trên trái ${ }^{a}$ & Dưới trái b & Trên phải c & Dưới phải ${ }^{d}$ & LCT & Giữa phảie \\
\hline Số TMP & 32 & 32 & 34 & 29 & 1 & 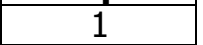 \\
\hline \multirow{2}{*}{ Tối đa (ms) } & $67,00 \pm 9,72 \mathrm{f}$ & $62,93 \pm 9,75 \mathrm{~g}$ & $64,81 \pm 9,53 \mathrm{~h}$ & $60,37 \pm 7,76 i$ & 67,00 & 56,00 \\
\hline & \multicolumn{6}{|c|}{$\mathbf{p}_{\mathrm{f}-\mathrm{g}}=\mathbf{0 , 0 0 9}, \mathrm{p}_{\mathrm{f}-\mathrm{h}}=0,060, \mathrm{p}_{\mathrm{f}-\mathrm{i}}=\mathbf{0 , 0 0 1}, \mathrm{p}_{\mathrm{g}-\mathrm{h}}=0,668, \mathrm{p}_{\mathrm{g}-\mathrm{i}}=0,768, \mathrm{p}_{\mathrm{h}-\mathrm{i}}=0,492$} \\
\hline \multirow{2}{*}{$\begin{array}{c}\text { Trung bình } \\
\text { (ms) }\end{array}$} & $56,65 \pm 8,52 \mathrm{k}$ & $48,67 \pm 13,38$ & $50,92 \pm 10,82 \mathrm{~m}$ & $49,76 \pm 8,11 \mathrm{n}$ & 57,20 & 45,00 \\
\hline & \multicolumn{6}{|c|}{$=\mathbf{0 , 0 0 2}, \mathbf{p}_{\mathrm{k}-\mathrm{n}}=\mathbf{0 , 0 0 0}, \mathrm{pl-m}=0,653, \mathrm{pl}_{\mathrm{l}-\mathrm{n}}=0,393, \mathrm{p}_{\mathrm{m}-\mathrm{n}}=0,856$} \\
\hline
\end{tabular}

a: 32 trường hợp ghi được điện đồ tai TMP trên trái; b: 32 trường hợp ghi được điện đồ TMP dưới trái, trong đó có 2 trường hợp khổng có điện đồ; c: 34 trường hợp ghi được điện đồ TMP dưới trái, trong đó có 2 trường hợp không có điện đồ; d: 29 trường hợp ghi được điện đồ TMP dưới trái, trong đó có 2 trường hợp không có điện đồ; $\mathrm{e}: 1$ trường hợp ghi được điện đồ TMP giữa phải. LCT: thân chung TMP trái.Sử dụng T-test.
Nhân xét: Khoảng A-PV tối đa qua lố TMP trên trái $(67,00 \pm 9,72 \mathrm{~ms})$ lớn hơn có ý nghĩa thống kê so với TMPdưới trái và dưới phải. Khoảng A-PV trung bình qua lỗ TMP trên trái $(56,65 \pm 8,52 \mathrm{~ms})$ là lớn nhất.

*Hình dạng điện đồ tĩnh mạch phổi: số cặp điện cực vòngghi được điện đổ khi tạo nhịp xoang vành là 645 .

Bảng 4. Hình dạng điện đồ TMP ở cặp điện cực vòng

\begin{tabular}{|c|c|c|c|c|c|}
\hline $\begin{array}{l}\text { Hình dang } \\
\text { điện đồ* }\end{array}$ & $\begin{array}{c}\text { Tống } \\
(\mathrm{n}=645)\end{array}$ & $\begin{array}{l}\text { Trên trái } \\
(\mathrm{n}=160)\end{array}$ & $\begin{array}{l}\text { Dưới trái } \\
(n=160)\end{array}$ & $\begin{array}{l}\text { Trên phải } \\
(n=170)\end{array}$ & $\begin{array}{l}\text { Dưới phải } \\
(n=155)\end{array}$ \\
\hline Không có & $9,1(6,0)$ & $1,9(2,8)$ & $15,0(5,6)$ & $11,2(3,2)$ & $8,4(2,9)$ \\
\hline 1 pha & $4,6(4,7)$ & $2,5(4,1)$ & $5,0(4,7)$ & $5,9(5,9)$ & $5,2(4,9)$ \\
\hline 2 pha & $19,4(8,4)$ & $13,1(8,9)$ & $23,8(12,0)$ & $19,4(2,6)$ & $21,3(4,9)$ \\
\hline 3 pha & $29,5(9,1)$ & $36,2(3,6)$ & $25,6(10,2)$ & $25,3(9,7)$ & $30,9(9,0)$ \\
\hline Nhiều thành phần & $31,6(8,7)$ & $34,4(10,6)$ & $23,1(7,8)$ & $35,3(5,9)$ & $33,6(5,4)$ \\
\hline Điện đồ kép & $5,8(5,9)$ & $11,9(6,8)^{1}$ & $7,5(3,6)^{2}$ & $2,9(2,9)^{3}$ & $0,6(1,4)^{4}$ \\
\hline & \multicolumn{5}{|c|}{$\mathbf{p}_{1-2}=\mathbf{0}, \mathbf{0 0 0}, \mathbf{p}_{\mathbf{1 - 3}}=\mathbf{0 , 0 0 0}, \mathbf{p}_{\mathbf{1 - 4}}=\mathbf{0 , 0 0 0} ;$ Mann - Whitney U Test } \\
\hline
\end{tabular}

*Trình bày số liệu dạng Trung bình (SD) (\%).

Hình dang điện đồ nhiều thành phần chiếm tỷ lệ cao nhất (với $31,6 \% \pm 8,7 \%$ ), tiếp đến là điện đồ 3 pha $(29,5 \% \pm 9,1 \%)$, điên đồ 2 pha $(19,4 \%$ $\pm 8,4 \%)$. Hình dạng điện đồ kép chiếm tỷ lệ $5,8 \% \pm 5,9 \%$. Hình dạng điện đồ kép gặp nhiều nhất ở TMP trên trái $(11,9 \% \pm 6,8 \%)$.

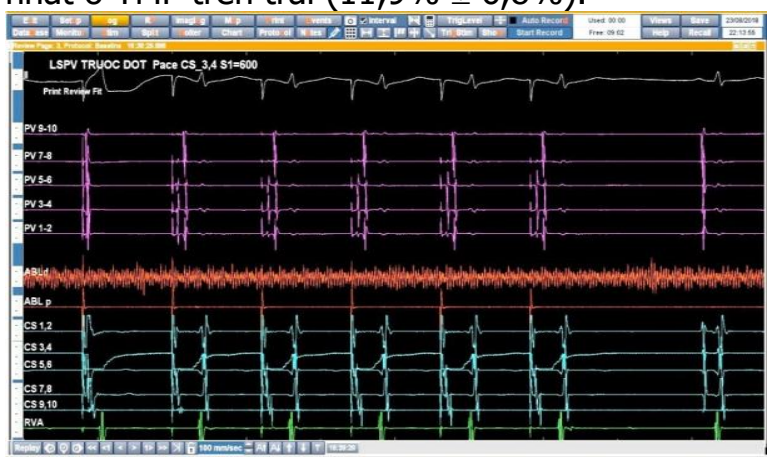

Hình 2. Hình ảnh điện đồ ghi tại tĩnh mạch phổi trên trái trước RF. Hình ảnh điện đồ tĩnh mạch phổi ở PV1-2, phía trước là điện đồ nhĩ (Bệnh nhân N.T.T 26 tuổi).

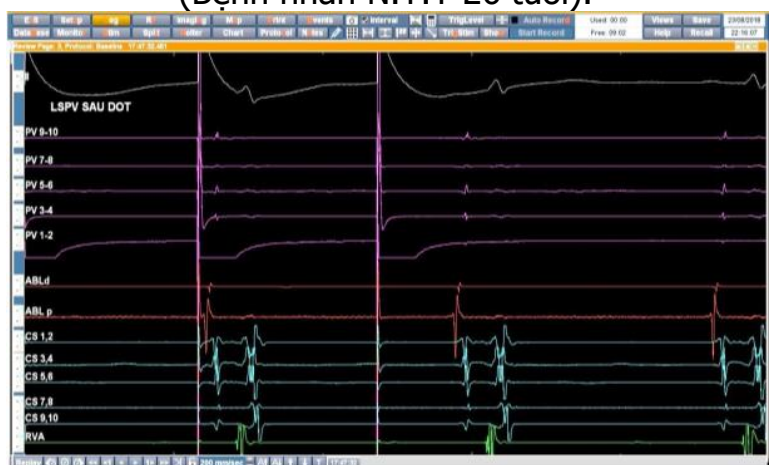

Hình 3. Hình ảnh điện đồ ghi tại tĩnh mạch phổi 
trên trái sau RF. Không còn hình ảnh điện đồ tại tĩnh mach phổi, đã kiểm tra exit block (Bênh nhân N.T.T 26 tuổi).

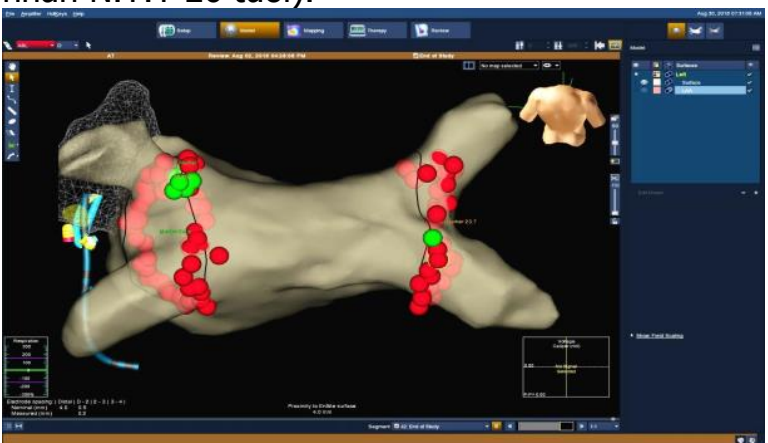

Hình 4. Hình ảnh cô lập 4 tĩnh mạch phổi ở bênh nhân. Điểm màu xanh là các điểm khi triệt đốt đã cô lập được điện đồ tại tĩnh mạch phổi tương ứng (PV isolation)(Bệnh nhân N.T.T 26 tuổi).

\section{BÀN LUÂN}

Tĩnh mạch phổi có vai trò rất quan trọng trong sinh lý bệnh của rung nhĩ. Nhiều nghiên cứu đã chỉ ra rẳng các ổ ngoại vị ở tĩnh mạch phổi có thể là trung tâm khởi phát rung nhĩ [8]. Một số nghiên cứu khác cho thấy, tĩnh mạch phổi không chỉ là ổ khởi phát rung nhĩ mà còn tham gia độc lập vào duy trì rung nhĩ.Điện đồghi tại tĩnh mạch phổi gồm ít nhất 2 thành phần; trong đó, thành phần đầu tiên là điện đồ far-field, tiếp theo là điện đồ của tĩnh mạch phổi sau một thời gian đẳng điện. Điện đồ tĩnh mạch phổi được định nghĩa là điện thế có tần số cao, có hình dạng sắc nét, thời gian $<50 \mathrm{~ms}$ và điện thế $>0,05$ $\mathrm{mV}$, và đi sau điện đồ nhĩ trái [4], [5]. Điện đồ tĩnh mạch phổi được xác định bằng sự biến mất của chúng sau khi tĩnh mạch phổi bị cô lập về điện học[4]. Tất cả bệnh nhân đều có điện đồ tại tĩnh mạch phổi (100\%). Đa số bệnh nhân có 4 tĩnh mạch phổi có điện đồ (chiếm tỷ lệ 80,0\%). Kết quả của tác giả Eva Hertervig cho thấy, có 91,0\% tĩnh mạch phổi ở bệnh nhân rung nhĩ được ghi nhận có hoạt động điện thế, trong khi đó ở bệnh nhân không rung nhĩ thì tỷ lệ này là thấp hớn nhiều với 11,0\% tĩnh mạch phổi [6]. Theo Wendel Moreira (2008), tiến hành ở 70 bệnh nhân rung nhĩ kịch phát, đã phát hiện hầu hểt các ổ khởi phát rung nhĩ xuất phát từ tĩnh mạch phổi. Hoạt động điện ở tĩnh mạch phổi trền trái được phát hiện ở 63 bệnh nhẩn chiếm tỷ lệ 90,0\%, ở tĩnh mạch phổi dưới trái là 52 bệnh nhân chiếm $74,3 \%$, ở tĩnh mạch phổi trên phải là 57 bệnh nhân chiếm $81,4 \%$ và ở tĩnh mạch phổi dưới phải là 16 bệnh nhân chiếm 22,9\% [3]. Theo kết quả của Hiroshi Tada, tỷ lệ tĩnh mạch phổi bên trái có điện đồ chiếm 64,0\%, tĩnh mạch phổi trên phải có điện đồ chiếm 95,0\%[4]. Ở tĩnh mạch phổi trên phải, các điện thế nhĩ nhỏ hơn nhiểu so với điện thế tĩnh mach phổi, và có rất ít chồng chéo giữa các điện thế trong lúc nhịp xoang. Vì vậy, thường không khó để phân biệt điện thế nhĩ và điện thế trong tĩnh mạch phổi trên phải. Trong khi đó, ở tĩnh mạch phổi trên trái và dưới trái, cân thiết tạo nhịp xoang vành để phân tách điện đồ nhĩ và điện đồ tĩnh mạch phổi. Trong 2 tĩnh mạch này, điện thế nhĩ và tĩnh mạch phổi có thể có biên độ tưởng tự nhau, có $65 \%$ có sự chồng chéo giữa 2 điện thế này ngay cả trong khi tạo nhịp xoang vành. Trong trường hợp này, tạo nhịp tiểu nhĩ trái có thể giúp xác định rõ điện thế tĩnh mạch phổi.

Điện đồ tĩnh mạch phổi được ghi nhận tại lỗ tĩnh mạch phổi, và dần truyền chậm quanh lỗ tĩnh mạch phổi có thể đóng vai trò khởi phát và duy trì rung nhĩ [6]. Theo đồng thuận của HRS/EHRA/ECAS, cô lập hoàn toàn điện thế hoạt động ở tĩnh mạch phổi là mục tiêu điều trị trong rung nhĩ, đặc biệt là rung nhĩ kịch phát. Điện thế tĩnh mạch phổi thường xuất hiện như là điện thế tai chỗ đi theo sau điên thế nhĩ sau một thời gian trễ. Đôi khi, điện thế đó khởi phát nhanh, liên tục, với nhiều hoạt động điện phân mảnh mà không có sự tách biệt giữa điện thế nhĩ và tĩnh mach phổi. Đó có thể là điê̂n thế môt pha, hai pha hoăc ba pha được ghi nhận tại lỗ tĩnh mạch phổi, và không có sự phân biệt rõ̉ ràng với điện thế nhĩ. Các nghiên cứu cho thấy có khoảng trễ nhất đinh trong dẫn truyền từ nhĩ đến tĩnh mạch phổi ở bệnh nhân rung nhĩ;nguyên nhân là dohoạt động điện học ở tĩnh mạch phổi khởi phát và duy trì cớn rung nhĩ, bên canh đó, có thể do các vòng vào lại có nguồn gốc từ lỗ tĩnh mach phổi [7]. Tác giả Jais và cộng sự cũng cho rẳng thời gian dẫn truyền nhĩ trái đến tĩnh mạch phổi ở bệnh nhân rung nhĩ lớn hơn so với không rung nhĩ, đồng thời thời gian trơ ngắn hơn, do đó tao điều kiện thuận lợi cho vòng vào lại ở bên trong và quanh lỗ tî̃nh mạch phổi. Kết quả nghiên cứu này cho thây, hình dạng điện đồ nhiêu thành phần chiếm tỷ lệ cao nhất (với $31,6 \% \pm 8,7 \%$ ), tiếp đến là điện đồ 3 pha $(29,5 \% \pm 9,1 \%)$, điện đồ 2 pha $(19,4 \% \pm 8,4 \%)$, trong đó điện đồ kép chiếm $5,8 \% \pm 5,9 \%$. Theo Dipen Shah, trong lúc nhịp xoang ở bệnh nhân rung nhĩ phát hiện được $100 \%$ tĩnh mạch phổi trên trái có điện đồ kép, $80 \%$ tĩnh mạch phổi dưới trái có điện đồ kép, $23 \%$ tĩnh mạch phổi trên phải có điên đồ kép và $100 \%$ tĩnh mạch dưới phải có điện đờ đơn. Trong khi đó, theo nghiên cứu của $\mathrm{E}$. Hertervig, ở bệnh 
nhân không rung nhĩ, điện đồ ghi được tại tĩnh mạch phổi chủ yếu là các điện thế 1 pha, hai pha hoặc 3 pha, có các hoạt động điện thế hẹp khổng có sự phân tách rõ ràng với hoạt động điện từ nhĩ [6]. Theo tác giả Milad El Haddad (2015) cho thây, sau khi cô lập tĩnh mạch phổi thì ở bệnh nhân rung nhĩ vẫn còn điện đồ tại tĩnh mạch phổi, tuy nhiên hình dạng điện đồ đã có nhiều thay đổi: trước cô lập chủ yếu là điện đồ 3 pha, nhiều thành phần và điện đồ kép, còn sau cô lập tĩnh mạch phổi thì điện đồ chủ yếu đơn giản và ít thành phần hơn[7].

\section{KẾT LUẬN}

Kết quả nghiên cứu cho thấy,cácbệnh nhân rung nhĩ kịch phát đềucó điện đồ tại ít nhất một tĩnh mạch phổi (chiếm 100\%), trong đó $80 \%$ bệnh nhân có cả 4 tĩnh mạch phổi có điện đồ.Khoảng thời gian dẫn truyền nhĩ - tĩnh mạch phổi (khoảng A-PV) tối đa và trung bình ở tî̃nh mạch phổi trên trái là dài nhất $(67,00 \pm 9,72 \mathrm{~ms}$ và $56,65 \pm 8,52 \mathrm{~ms}$, tương ứng). Hình dạng điện đồ tĩnh mạch phổi thường gặp là điện đồ nhiểu thành phần $(31,6 \% \pm 8,7 \%)$. Điện đồ kép chiếm tỷ lệ $5,8 \% \pm 5,9 \%$, trong đóhình dạng điện đồ kép gặp nhiều nhất ở tĩnh mạch phổi trên trái $(11,9 \% \pm 6,8 \%)$.

\section{TÀI LIÊU THAM KHẢO}

1. Chugh S.S., Havmoeller R., Narayanan K., et al (2014). Worldwide Epidemiology of Atrial Fibrillation: A Global Burden of Disease 2010 Study. Circulation, 129(8), 837-847.

2. Snoer A.H., Ellemann $K_{\text {., }} \&$ Wienecke $T$. (2014). High Prevalence of Paroxysmal Atrial Fibrillation in A Selected Population of Patients with Stroke and Transient Ischemic Attack, 5.

3. Moreira W., Manusama R., Timmermans $\mathbf{C}_{\text {. }}$ et al (2008). Long-term follow-up after cryothermic ostial pulmonary vein isolation in paroxysmal atrial fibrillation. Journal of the American College of Cardiology, 51(8), 850-855.

4. Tada H., Oral H., Greenstein R., et al (2002) Differentiation of atrial and pulmonary vein potentials recorded circumferentially within pulmonary veins. Journal of cardiovascular electrophysiology, 13(2), 118-123.

5. Haïssaguerre M., Shah D.C., Jaïs $P_{\text {., }}$ et al (2000). Electrophysiological breakthroughs from the left atrium to the pulmonary veins. Circulation, 102(20), 2463-2465.

6. Hertervig E., Kongstad O., Ljungstrom E., et al (2008). Pulmonary vein potentials in patients with and without atrial fibrillation. Europace, 10(6), 692-697.

7. El Haddad M., Houben R., Berte B., et al (2015). Bipolar electrograms characteristics at the left atrial-pulmonary vein junction: Toward a new algorithm for automated verification of pulmonary vein isolation. Heart Rhythm, 12(1), 21-31.

8. Haissaguerre M., Jaïs P., Shah D.C., et al (1998). Spontaneous initiation of atrial fibrillation by ectopic beats originating in the pulmonary veins. New England Journal of Medicine, 339(10), 659-666.

\title{
ĐĂC ĐIỂM LÂM SÀNG VÀ TÌNH HÌNH ĐỀ KHÁNG KHÁNG SINH TRÊN BỆNH NHÂN CHỐC TẠI BỆNH VIỆN DA LIỄU THÀNH PHỐ CẦN THO' NĂM 2020
}

\author{
Trần Nguyễn Anh Thu*, Huỳnh Văn Bá*, \\ Nguyễn Thị Thùy Trang*, Lạc Thị Kim Ngân*, Phạm Thanh Thảo*
}

\section{TÓM TẮT}

Mục tiêu: Mô tả đặc điểm lâm sàng và tình trạng kháng thuốc của các vì khuẩn nhiếm trên bệnh nhân chốc đến khám tại bệnh viện Da Liễu TP. Cần Thơ từ 06/2020 - 12/2020. Đối tượng và phương pháp: Mô tả cắt ngang trên mẫu là 55 bệnh nhân, được lấy bệnh phẩm sang thương trên da, nuôi cấy và̀ làm kháng sinh đồ. Kết quả: 35 trường hợp bệnh nhân bị chốc có kết quả cây vi khuẩn dương tính $(63,6 \%)$.

*Trường Đại học Y Dược Cần Thơ Chịu trách nhiệm chính: Trần Nguyễn Anh Thư Email: trannguyenanhthu.y39@gmail.com Ngày nhận bài: 15/6/2021

Ngày phản biện khoa học: 14/7/2021

Ngày duyệt bài: 15/8/2021
Trong số này, chốc không bóng nước là $61,8 \%$, chốc bóng nước là $25,5 \%$ và chốc loét là $12,7 \%$. Đa số vi khuẩn phân lập được là S.aureus (93,8\%). Tỉ lệ S.aureus kháng với penicillin và erythromycin là $100 \%$, kháng với amoxicillin/acid clavulanic là $93,5 \%$, còn nhạy với cefuroxime, oxacillin, tetracyclin, ciprofloxacin, levofloxacin, linezolid và vancomycin, có 2 trường hớp kháng với vancomycin thuộc thể chốc loét. Tỉ lệ chủng tụ câu vàng kháng methicillin (MRSA) được phát hiện trong nghiên cứu là $87,1 \%$. Và cả 3 ca cây ra S.pyogenes (chiếm 8,6\%) vẫn còn nhay với penicillin. Kết luận: Chốc không bóng nước là thể bệnh thường găp nhất trên lâm sàng. Tác nhân gây bênh chủ yếu làs.aureus, gần nhữ kháng toàn bộ với penicillin, erythromycin, và vẫn còn nhay cao với oxacillin, cefuroxime và vancomycin. Tư khóa: Chốc, kháng kháng sinh, S.aureus, S. pyogenes. 


\section{SUMMARY \\ THE CLINICAL FEATURES AND THE ANTIBIOTIC RESISTANCE OF BACTERIA CAUSING IMPETIGO AT CAN THO HOSPITAL CITY OF DERMATO- VENEREOLOGY}

Objective: To demonstrate clinical features and antibiotic resistance of bacteria causing impetigo in patients at Can Tho city Hospital of DermatoVenereology from June 2020 to December 2020. Materials and methods: A descriptive crosssectional study of 55 patients, clinical characteristics of patients with impetigo were recorded. Bacteria from impetigo pus were isolated. Antiobiogram examination with multiple antibiotics was performed. Results: 35 $(63,6 \%)$ patients with impetigo had positive bacteriological cultures. Regarding clinical features, non-bullous impetigo was $61,8 \%$, bullous impetigo was $25,5 \%$ and ecthyma was $12,7 \%$. On the examination of biology features, S. aureus was $93.8 \%$ of cases. Penicillin-resistant S.aureus and erythromycin-resistant S.aureus was 100\%; amoxicillin/acid clavulanic-resistant S. aureus was 93,5\%; bacteria were sensitive to cefuroxime, oxacillin, tetracyclin, ciprofloxacin, levofloxacin, linezolid and vancomycin; the 3 case vancomycinresistant was ecthyma. Methicillin-Resistant Staphylococcus aureus (MRSA) was $87,1 \%$.And 2 S.pyogenes cases $(8,6 \%)$ remained susceptible to penicillin. Conclusion: Non-bullous impetigo was the most common clinical feature. The main bacterium is S.aureus, which was completely resistant to penicillin and erythromycin. On the other hand, it was still highly sensitive to oxacillin,cefuroxime, and vancomycin.

Key words: Impetigo, antiobiotics resistance, S.aureus, S. pyogenes.

\section{I. ĐẠT VẤN ĐỀ}

Chốc là bệnh nhiễm trùng da nông rất thường găp trong chuyên ngành Da Liễu Tại Khoa Khám Bệnh của bệnh viện Da Liễu TP. Hồ Chí Minh, trong 5 năm (2008 - 2012), mỗi năm có khoảng 2000-3000 trẻ em được chẩn đoán bệnh chốc. Nếu không điều trị hoặc điều trị khổng đúng bệnh sẽ lan rộng, có thể gây ra các biến chứng nguy hiểm. Do đó, chẩn đoán và điều trị sớm, đúng thuốc, đúng liều là một yêu cầu rất cần thiết. Theo y văn, tại các nước đang phát triển, S.pyogenes là tác nhân gây bệnh chủ yếu [5]. Và việc điều trị hiệu quả là dựa vào tình trạng kháng thuốc của tác nhân gây bệnh tại thời điểm nhất định. Tuy nhiên, ở Việt Nam nói chung và Cần Thơ nói riêng trong 5 năm gần đây chưa có nghiên cứu nào khảo sát tác nhân gây bệnh chốc trẻ em cũng như sự kháng thuốc của các tác nhân này. Xuất phát từ những lý do trên, chúng tôithực hiên đề tài "Đặc điểm lâm sàng và tình hình đề kháng kháng sinh của vi khuẩn nhiễm trên bệnh nhân chốc tại Bệnh viện Da liễu thành phố Cần Thơ năm 2020" với mục tieu:

- Mô tả đặc điểm lâm sàng của bệnh nhân chốc điều trị tại Bệnh viện Da liếu Thành phố Cần Thơ năm 2020.

- Xác định tỷ lệ nhiễm và đề kháng với kháng sinh của các loại vi khuẩn trên bệnh nhân chốc điều trị tại Bệnh viện Da Liễu Thành phố Cần Thơ năm 2020.'

\section{II. ĐỐI TƯỢNG VÀ PHƯƠNG PHÁP NGHIÊN CỨU}

1. Đối tượng nghiên cứu. Tất cả bệnh nhân được chẩn đoán chốc đến khám và điều trị tại Bệnh viện Da liễu Thành phố Cần Thơ năm 2020.

Tiêu chuẩn chọn mẫu: Chọn mẫu nghiên cứu là những bệnh nhân được chẩn đoán bệnh chốc điều trị tại Bệnh viện Da liễu Thành Phố Cần Thơ.

Tiêu chuẩn chẩn đoán bệnh chốc bao gồm:

- Thương tổn: bóng nước, mụn nước hóa mủ nhanh, đóng mày. Mày đóng mày màu vàng nâu hoặc màu vàng mật ong.

- Vị trí: miệng, mũi, thân mình, tay chân.

- Cơ năng: ngứa, đau, rát.

- Toàn thân: sốt hoặc hạch viêm.

- Nhuộm Gram/nuôi cây

\section{Tiêu chuấn loai trừ}

- Bệnh nhân có bệnh lý toàn thân nặng (suy gan, suy thận) hoặc chưa ổn định.

- Bệnh nhân không đồng ý tham gia nghiên cứu

2. Thiêt kế nghiên cứu. Mô tả cắt ngang

Cỡ mẫu: $n=55$

3. Phương pháp tiến hành. Khám lâm sàng và làm bệnh án, thu thập số liệu.

\section{Chẩn đoán chốc trên lâm sàng dựa vào} các đặc điểm:

Chốc bóng nước: nhiêu mụn nước tiến triển nhanh thành bóng nước chùng, nông, kích thước khoảng $1-2 \mathrm{~cm}$, chứa dịch vàng trong hoặc đục dần tạo thành bóng mủ. Bóng nước võ nhanh trong 1-2 ngày để lại những vết trợt, đóng mài, giới hạn rõ. Mài thường mỏng, có màu vàng hay nâu nhạt, vết trợt có viên thượng bì xung quanh. Có thể gặp ở bất cứ vị trí nào trên cơ thể, nhưng thường ở mặt, quanh mũi, miệng, thân mình.

- Chốc không bóng nước: nhiêu mụn nước hay mụn mủ, vỡ nhanh, đóng mài vàng mật ong với viền mủ rất đặc trưng, có mảng hồng ban viêm đỏ xung quanh đường kính khoảng $2 \mathrm{~cm}$. Thương tổn tiến triển lan rộng nhanh ra xung quanh tạo sang thương vệ tinh. Vị trí thường gặp ở mặt, nhất là quanh mũi, và ở tay, chân (sau chân thương).

- Chốc loét bắt đầu với những mụn nước hoặc mụn nước - mụn mủ, sau đó tiến triển lan rộng, 
sâu hơn, đóng mài dày trong vài ngày. Khi mài tróc ra sẽ thây vết loét nông, hình đĩa, đáy màu đỏ và bờ nhô cao. Thường xảy ra ở 2 chi dưới, nhất là cẳng chân và lưng bàn chân.

Cấy vi khuẩn: bệnh nhân được lấy bệnh phẩm bằng tăm bông vô trùng phết ở trung tâm thương tổn, cho vào ống nghiệm có chứa môi trường chuyên chở và sau đó cấy trực tiếp lên môi trường thạch máu, tại phòng xét nghiệm khuẩn của Bệnh viện trường Đại học Y Dược Cần Thơ.

Làm kháng sinh đồ: theo Qui trình thao tác chuẩn về thử nghiệm tính nhạy cảm kháng sinh (CLSI) [2].

4. Xử lý số liệu: Số liệu được nhập, phân tích và xử lý bằng phần mềm SPSS 18.0.

\section{KẾT QUẢ NGHIÊN CỨU}

Trong khoảng thời gian 6 tháng từ tháng 06/2020 đến tháng 12/2020 chúng tôi thu thập được 55 bệnh nhân có thương tổn chốc thỏa mãn tiêu chuẩn chọn bệnh ban đầu, trong đó kết quả cấy dương tính 35 bệnh nhân (61,8\%).

1. Một số đặc điểm dịch tễ của bệnh chốc

Tuổi và giới. Tuổi nhỏ nhất là 10 tháng, lớn nhất là 11 tuổi, trung bình 3,67 $\pm 3,12$. Tập trung nhiều ở nhóm tuổi 2-6 chiếm 58,2\% (Bảng 1). Nam chiếm tỷ lệ cao hơn nữ (Bảng 2)

Bảng 1. Tý lẹ bệnh nhân chốc theo tuổi

\begin{tabular}{|c|c|c|}
\hline Nhóm tuối & Tân số (n) & Tỷ lệ (\%) \\
\hline$<2$ & 14 & $25,5(\%)$ \\
\hline $2-6$ & 32 & $58,2(\%)$ \\
\hline$\geq 6$ & 9 & $16,4(\%)$ \\
\hline Tổng cộng & 55 & $100(\%)$ \\
\hline TB \pm ĐLC & \multicolumn{2}{|c|}{$3,67 \pm 3,12$} \\
\hline Bảng 2. $T y$ & ệnh nhân chá & heo giới tính \\
\hline Giới tính & Tân số (n) & Tỷ lệ (\%) \\
\hline Nam & 37 & $67,3(\%)$ \\
\hline Nữ & 18 & $32,7(\%)$ \\
\hline Tống cộng & 55 & $100(\%)$ \\
\hline
\end{tabular}

2. Đặc điếm lâm sàng của bênh nhân chốc

Bảng 3. Tỷ lệ bệnh nhân chốc theo thể lâm sàng

\begin{tabular}{|c|c|c|}
\hline Thể lâm sàng & $\begin{array}{c}\text { Tân số } \\
(\mathbf{n})\end{array}$ & $\begin{array}{c}\text { Tỷ lệ } \\
(\%)\end{array}$ \\
\hline Chốc không bóng nước & 34 & $61,8(\%)$ \\
\hline Chốc bóng nước & 14 & $25,5(\%)$ \\
\hline Chốc loét & 7 & $12,7(\%)$ \\
\hline Tống cộng & $\mathbf{5 5}$ & $\mathbf{1 0 0} \% \mathbf{\%}$ \\
\hline
\end{tabular}

Nhận xét: thể lâm sàng chốc không bóng nước chiếm tỷ lệ cao nhất là $61,8 \%$.

Bảng 4. Mối liên liên quan giữa nơi cư trú theo thể lâm sàng

\begin{tabular}{|c|c|c|c|c|}
\hline \multirow{2}{*}{ Thể lâm sàng } & \multicolumn{2}{|c|}{ Nơi cư trú } & \multirow[b]{2}{*}{ Tổng } & \multirow[b]{2}{*}{ p } \\
\hline & Thành thị & Nông thôn & & \\
\hline Chốc không bóng nước & $13(39,45 \%)$ & $20(60,6 \%)$ & 33 & \multirow{4}{*}{$p=0,021$} \\
\hline Chốc bóng nước & $0(\%)$ & $14(100 \%)$ & 14 & \\
\hline Chốc loét & $3(37,5 \%)$ & $5(62,5 \%)$ & 8 & \\
\hline Tống & $26(29,1 \%)$ & $39(70,9 \%)$ & 55 & \\
\hline
\end{tabular}

Nhận xét: hầu hết các thế bệnh đều có nơi cư trú ở nông thôn chiếm tỷ lệ cao hơn thành thị trong đó có chốc bóng nước là $100 \%$ đều ở nông thôn, sự khác biệt này có ý nghĩa thống kê với $\mathrm{p}=0,021$.

3. Tình trạng kháng thuốc của vi khuẩn gây bệnh chổc

Bảng 5. Tỷ lệ tác nhân vi khuẩn gây bệnh chốc

\begin{tabular}{|c|c|c|}
\hline Tác nhần & Tân số (n) & Tỷ lệ \% \\
\hline Staphylococcus aureus & 31 & $93,8(\%)$ \\
\hline Streptococcus pyogenes & 3 & $8,6(\%)$ \\
\hline Vi khuấn khác & 1 & $2,9(\%)$ \\
\hline Tống & $\mathbf{3 5}$ & $\mathbf{1 0 0}(\%)$ \\
\hline
\end{tabular}

*1 ca Escherichia coli

Nhận xét: Đa số tác nhân gây bệnh là Staphylococcus aureus chiếm 93,8\% (Bảng 5).

S. aureus kháng với nhiêu loại kháng sinh trong đó $100 \%$ kháng với clindamycin, penicillin, erythromycin, trimetroprim-sufamethoxazol, kế đến là amoxicillin/acid clavulanic và ceftriaxon $(93,5 \%)$, cefuroxime và oxacillin là $87,1 \%$, cefixim chiếm $83,9 \%$, tiếp theo lần lượt là tetracylin $(58,1 \%)$, ciprofloxacin $(35,5 \%)$, levofloxacin $(25,8 \%)$ và cuối cùng là vancomycin
(6,5\%) (Bảng 6).

Bảng 6. Kết quả kháng sinh đồ của 35 trường hợp S. aureus

\begin{tabular}{|c|c|c|c|c|}
\hline \multirow{2}{*}{$\begin{array}{c}\text { Loại kháng } \\
\text { sinh }\end{array}$} & $\begin{array}{c}\text { Kháng } \\
\text { Số ca } \\
\text { (n) }\end{array}$ & $\begin{array}{c}\text { Tý lệ } \\
\text { (\%) }\end{array}$ & $\begin{array}{c}\text { Số ca } \\
\text { (n) }\end{array}$ & $\begin{array}{c}\text { Tỷ lệ } \\
(\mathbf{\%})\end{array}$ \\
\hline Clindamycin & 31 & 100 & 0 & 0 \\
\hline Penicillin & 31 & 100 & 0 & 0 \\
\hline Erythromycin & 31 & 100 & 0 & 0 \\
\hline Trimetroprim & 31 & 100 & 0 & 0 \\
\hline $\begin{array}{c}\text { Amoxicillin/acid } \\
\text { clavulanic }\end{array}$ & 29 & 93,5 & 2 & 6,5 \\
\hline Ceftriaxon & 29 & 93,5 & 2 & 6,5 \\
\hline Cefuroxim & 27 & 87,1 & 4 & 12,9 \\
\hline Oxacillin & 27 & 87,1 & 4 & 12,9 \\
\hline Cefixim & 26 & 83,9 & 5 & 16,1 \\
\hline Tetracylin & 18 & 58,1 & 13 & 41,9 \\
\hline Ciprofloxacin & 11 & 35,5 & 20 & 64,5 \\
\hline Levofloxacin & 8 & 25,8 & 23 & 74,2 \\
\hline
\end{tabular}


\begin{tabular}{|l|l|l|l|l|} 
Vancomycin & 2 & 6,5 & 29 & 93,5 \\
\hline
\end{tabular}

Bảng 7. Tỷ lệ đề kháng một số kháng sinh nhóm $\beta$-lactams của chủng MRSA so với chủng MSSA

\begin{tabular}{|c|c|c|}
\hline \multirow{2}{*}{ Kháng sinh } & \multicolumn{2}{|c|}{ Tác nhân gây bệnh } \\
\cline { 2 - 3 } & MRSA & MSSA \\
\hline penicillin & $100 \%$ & $100 \%$ \\
\hline cefuroxim & $88,9 \%$ & $75 \%$ \\
\hline tetracylin & $55,6 \%$ & $25 \%$ \\
\hline
\end{tabular}

Cả 2 chủng MRSA và MSSA gân như kháng tất cả với penicillin. Chủng MRSA có tỷ lệ đề kháng các kháng sinh nhóm $\beta$-lactams khác penicillin cao hơn chủng MSSA (Bảng 7).

Nhìn chung, tỷ lệ đề kháng của MRSA và MSSA đối với erythromycin là rất cao chiếm $100 \%$, chi tiết hơn ta thây chủng MRSA kháng ciprofloxacin (33,3\%), levofloxacin (22,2\%) và vancomycin $(7,4 \%)$ cao hơn chủng MSSA, hơn nữa là chủng MSSA chưa ghi nhận kháng với levofloxacin và vancomycin (Bảng 8 ).

Bảng 8. Tỷ lệ đề kháng một số kháng sinh tiêu biểu không phải nhóm $\beta$-lactams của chủng MRSA so với chüng MSSA

\begin{tabular}{|c|c|c|}
\hline \multirow{2}{*}{ Kháng sinh } & \multicolumn{2}{|c|}{ Tác nhân gây bệnh } \\
\cline { 2 - 3 } & MRSA & MSSA \\
\hline Erythromycin & $100 \%$ & $100 \%$ \\
\hline Ciprofloxacin & $33,3 \%$ & $25 \%$ \\
\hline Levofloxacin & $22,2 \%$ & $0 \%$ \\
\hline Vancomycin & $7,4 \%$ & $0 \%$ \\
\hline
\end{tabular}

\section{BÀN LUẦN}

1. Đặc điểm dịch tễ mẫu nghiên cứu. Theo nghiên cứu của chúng tôi tuổi nhỏ nhất là 10 tháng, lớn nhất là 11tuổi, trung bình là 3,67 $\pm 3,12$. Tập trung nhiêu nhất ở nhóm tuổi 2-6 $(58,2 \%)$ (bảng 1$)$. Về giới, nam $(67,3 \%)$ chiếm tỷ lệ cao hơn nữ (32,7\%) (bảng 2 ). Kết quả này cũng phù hợp với các tác giả Mai Thị Liên (2016) [1].

2. Đặc điểm lâm sàng của mẫu nghiên cứu. Theo kết quả nghiên cứu của chúng tôi về thể lâm sàng, chốc không bóng nước chiếm tỷ lệ cao nhất là $61,8 \%$ (bảng 3). Theo y văn, tỷ lệ chốc không bóng nước là 70\% [5]. So sánh với các nghiên cứu của các tác giả Cole $C$ và cộng sự (2007), Abdullash SH và cộng sự (2015) cho thây tỷ lệ này gân như xấp xỉ lân lượt là $70 \%$ và $66,7 \%[4]$.

Về nơi cư trú, theo nghiên cứu của chúng tôi, tỷ lệ nơi cử trú ở nông thôn (70,9\%) chiếm tỷ lệ cao hơn so với thành thị $(29,1 \%)$, hâuu hết các thể bệnh đều có nơi cư trú ở nông thôn chiếm tỷ lệ cao hơn thành thị trong đó có chốc bóng nước là $100 \%$ đều ở nông thôn, sự khác biệt này có ý nghĩa thống kê $(p=0,021)$. Kết quả này tương tự với tác giả Mai Thị Liên (2016) là tỷ lệ bệnh nhân mắc bệnh chốc ở thành thị là 44,29\% thấp hơn so với ở nông thôn- miên núi là 55,71\% [1].

3. Tác nhân gây bệnh chốc. Theo y văn, tại các nước công nghiệp, nguyên nhân của chốc không bóng nước thường do $\mathrm{S}$. aureus, còn tại các nước đang phát triển thì $S$. pyogenes vẫn là tác nhân thường gặp [5]. Tuy nhiên, theo kết quả nghiên cứu của chúng tôi, S.aureus là tác nhân gây bệnh chủ yếu trong chốc nói chung $(93,8 \%)$, và cả trong thể lâm sàng chốc không bóng nước nói riêng, chỉ một số ít do S.pyogenes $(2,9 \%)$ (bảng 5$)$. Kết quả nghiên cứu này phù hợp với nghiên cứu của tác giả Kumar $R$, và cộng sự được thực hiện tại bệnhviện Nhi ở Ấn Độ (2002) với tỷ lệ cấy S.pyogenes trong bệnh chốc ở trẻ em là 2,6\% (2/75 mẫu bệnh phẩm lấy từ thương tổn da) [6].

\section{Tình hình kháng thuốc của vi khuẩn nhiễm trên bệnh nhân chốc}

S. aureus. Theo kết quả nghiên cứu của chúng tôi, S. aureus kháng với nhiêu loại kháng sinh trong đó $100 \%$ kháng với clindamycin, penicillin, erythromycin, trimetroprim, kế đến là amoxicillin/acid clavulanic và ceftriaxon $(93,5 \%)$, cefuroxime và oxacillin là $87,1 \%$, cefixim chiếm $83,9 \%$, tiếp theo lân lượt là tetracylin $(58,1 \%)$, ciprofloxacin $(35,5 \%)$, levofloxacin $(25,8 \%)$ và cuối cùng thâp nhất là vancomycin $(6,5 \%)$. Kết quả này khác với nghiên cứu của Liu Y (2009) và Trân Nguyên Ánh Tú (2016) với tỷ lệ đề kháng penicillin thì gân như tương đồng, nhưng tỷ lê đề kháng với các loại kháng sinh khác thì cho thấy thấp hơn, nguyên nhân có thể là do sự khác biệt về thời điểm nghiên cứu cách xa nhau, tình trạng kháng thuốc đã tăng dân theo thời gian [3], [7].

Theo kết quả nghiên cứu của chúng tôi cho thấy đối với các kháng sinh thuộc nhóm $\beta$ lactams, ngoại trừ tỷ lệ đề kháng đối với penicillin của cả 2 chủng đêu rất cao (100\%), còn lại chủng MRSA có tỷ lệ đề kháng với các kháng sinh thuộc nhóm $\beta$-lactams khác cao hơn chủng MSSA. Tương tự, khi so sánh tỷ lệ đề kháng giữa MRSA và MSSA với một số kháng sinh tiêu biểu không phải $\beta$-lactams cũng cho kết quả MRSA có tỷ lệ kháng cao hơn. Kết quả này cũng tuơng tự với nghiên cứu của Trân Nguyên Ánh Tú (2016) [3].

S. pyogenes. Theo kết quả nghiên cứu của chúng tôi, cả 3 ca cấy vi khuẩn là Streptococcus pyogenes đều kháng với tetracylin, 2 ca kháng với erythromycin, 1 ca kháng với clindamycin không có ca nào kháng với penicillin. Kết quả này phù hợp với nghiên cứu của Richter (2015) 
không có trường hợp nào S. pyogenes kháng với penicillin [8].

\section{KẾT LUÂN}

Bệnh nhân bi bênh chốc trong mẫu nghiên cứu chủ yếu là chốc không bóng nước, với tỷ lệ $61,8 \%$, kế đến là chốc loét $25,5 \%$ và chốc bóng nước 8,6\%.

Tác nhân gây bệnh chủ yếu là $S$. aureus với tỷ lệ là $63,6 \%$ trong các trường hợp cây dương tính.

Tình trạng đề kháng với kháng sin penicillin của $\mathrm{S}$. aureus là rất cao $(98,5 \%)$, kế đến là erythromycin (81,5\%), clindamycin $(69,2 \%)$. Tuy nhiên, vi trùng này vấn còn nhạy cao với oxacillin $(61,8 \%)$, cefuroxime $(83,1 \%)$ và tỷ lệ MRSA là $13,8 \%$. Riêng 2 trường hợp $S$. pyogenes đều nhạy cảm với penicillin.

\section{TÀI LIỆ THAM KHẢO}

1. Mai Thị Liên (2016), "Đă̆c điểm lâm sàng, yễu tố liên quan và hiệu quả điều trị bệnh chốc bằng cefixim kết hợp với fucidin", Luận văn thạc sĩ y hơc, Trường đại học Y Hà Nội, Hà Nội,

2. Đố Thị Thúy Nga (2011), "Tiêu chuấn đọc kết quả kháng sinh đồ và MIC", Qui trình thao tác chuẩn về thử nghiệm tính nhạy cám kháng sinh (21),
3. Trân Nguyên Ánh Tú (2016), "Tình trạng kháng thuốc in vitro của Staphyloccocus aureus và Streptococcus pyogennes gây bênh chốc ở trẻ em đến khám tại Bệnh viện Da liễu thành phố Hồ Chí Minh", Tạp chí Y học Thành Phố Hồ Chí Minh, 20(2), tr.63-69.

4. Cole C. \& Gazewood J. (2007), "Diagnosis and treatment of impetigo ", Am Fam Physician 75(6), pp.859-864.

5. James G.H. Dinulos (2020), "Impetigo", Habif's Clinical Dermatology: A Color Guide in Diagnosis and Therapy, Elsevier, pp. 331-340.

6. Vohra $H$ Kumar $R$, Chakraborty $A$, et a (2009), "Epidemiology of group A streptococcal pharyngitis \&impetigo: a cross-sectional \& follow up study in a ruralcommunity of northern India", The Indian journal of medicalresearch,130(6), pp. 765-771.

7. Kong $F$ Liu $Y$, Zhang $X$, et al (2009), "Antimicrobial susceptibility of Staphylococcus aureus isolated from children with impetigo in China from 2003 to 2007 shows communityassociated methicillin-resistant Staphylococcus aureus to be uncommon and heterogeneous", The British journal of dermatology, 161(6), pp. 1347-1350.

8. Heilmann KP Richter SS, Beekmann SS (2015), "Macrolide-resistant Streptococcus pyogenes in the UnitedStates, 2012-2013", Clinical Infection Diseases,41(1), pp. 599 - 608.

\section{KẾT QUẢ SớM PHẪU THUÂT CẮT U MÔ ĐỆM (GIST) DẠ DÀY TẠI KHOA NGOẠI - BÊ̂NH VIỆN BẠCH MAI}

\section{Lun Panha ${ }^{1}$, Trần Quế Sơnn ${ }^{1,2}$, Trần Hiếu Học ${ }^{1,2}$}

\section{TÓM TẮT}

Mục tiêu: mô tả một số đặc điểm lâm sàng, cận lâm sả̉ng và kết quả phâ̂u thuât u mô đêm cứa da dày. Đối tượng và phương pháp nghiên cứu: mổ tả loạt ca bểnh, những trường hợp u mô đệm của da dày được phẫu thuật tại bệnh viện Bạch Mai từ 2016 đên 2019. Kết quả: 50 bênh nhẩn với tuổi trung bình $56,3 \pm 12,6$ và tỉ lệ nam/nữ là 0,79 . Đau bụng là triệu chứng thường gặp $(94 \%)$, nội soi thây có loét trên u $52 \%$ và vị trí u chủ yếu ở hang vị và thân vị $(74 \%)$; cắt lớp vi tính thấy kích thước u $9,2 \pm 9,0 \mathrm{~cm}$, bờ đều $88 \%$, ngấm thuốc manh $72 \%$; hai dâuu ân CD117 và CD 34 thấy $100 \%$. Cắt da dày hình chêm là kỹ thuật dùng nhiêuu nhất $76 \%$; thời gian trung tiện $1,9 \pm 0,7$ ngày, rút sonde dạ dày $2,5 \pm 1,3$ ngày, cho ăn trở lại $3,2 \pm 1,2$ ngày, nằm viện sau mổ trung bình 6,2 ngày. Tai biến chảy máu trong mổ $2(4,0 \%)$, biến chứng

\footnotetext{
${ }^{1}$ Trường Đại học Y Hà Nội

${ }^{2}$ Khoa Ngoại bệnh viện Bạch mai

Chịu trách nhiệm chính: Trần Hiếu Học.

Email: hieuhoc1305@gmail.com

Ngày nhận bài: 26/6/2021

Ngày phản biện khoa học: 30/7/2021

Ngày duyệt bài: 19/8/2021
}

nhiễm trùng vết mổ 4 (8,0\%). Kết luận: Chẩn đoán bệnh chủ yếu dựa vào nội șoi, chẩn đoán hình ảnh và xác định bằng hóa mô miển dịch. Phẫu thuật có kết quả sớm tốt, song cần theo dõi lâu dài thêm.

Tư khóa: U mô đệm đường tiêu hóa, dạ dày, phẫu thuật.

\section{SUMMARY}

\section{EARLY RESULTS OF SUGICAL TREAMENT OF GASTROINTESTINAL STROMAL TUMOR LOCALIZED IN THE STOMACH AT SURGERY, BACH MAI HOSPITAL}

Objectives: To describe some clinical, paraclinical features and surgical results of this disease. Material and methods: A descriptive study of the case series of GIST localized in the stomach operated at Bach Mai hospital from 2016 to 2019. Results: There was 50 patients with mean age $56.3 \pm 12.6$ and male/female ratio of 0,79 . The abdominal pain was common symptom (94\%), the endoscopy showed mucosal ulceration $52 \%$ and tumor locations were primarily at body and pyloric antrum (74\%); computed tomography showed the tumor size of $9.2 \pm 9.0 \mathrm{~cm}$, regular margins $88 \%$, two immune markers CD117 and $C D 34$ were present in $100 \%$. The wedge gastrectomy was most commonly used technique 
(76\%); mean time of gas was of $1.9 \pm 0.7$ days, gastric sonde removal of $2.5 \pm 1.3$ days, re-feeding $3.2 \pm 1.2$ days, length of hospital stay of 6.2 day. The peroperative bleeding was of $4.0 \%$, wound infection of $8.0 \%$. Conclusion: The diagnosis was mainly based on endoscopy and computed tomography and the accuracy was on immunohistochemistry. Early results are usually good, but further long-term follow-up was needed.

Keywords: Gastrointestinal stromal tumor, stomach, surgery.

\section{I. ĐĂT VẤN ĐỀ}

U mô đệm đường tiêu hóa (GIST: Gastrointestinal Stromal Tumor) là u trung mô ác tính thường gặp của đường tiêu hoá, chiếm khoảng 1 - 3\% các u ác tính của ống tiêu hóa; trong đó vị trí tại dạ dày là thường gặp nhất với tỷ lệ 39-70\%[1,2]. Các triệu chứng lâm sàng thường mơ hồ và không điển hình, thậm chí không có biểu hiện gì khi u nhỏ nên dễ bị bỏ sót. Phần lớn bệnh nhân được phát hiện ở giai đoạn muộn hoặc phát hiện tình cờ qua nội soi tiêu hóa và các phương tiện chẩn đoán hình ảnh khác. Việc chẩn đoán xác định chủ yếu dựa vào kết quả giải phẫu bệnh và hóa mô miễn dịch $[2,3]$.

Điều trị phẫu thuật vẫn là phương pháp điều trị triêtt căn căn bản. Gần đây nhờ sự phát triển của kỹ thuật mổ và các trang thiết bị y tế đồng thời trình độ của phẫu thuật viên ngày càng được cải thiện đã đem lại nhứng kết quả tốt hơn trong điều trị GIST dạ dày $[4,5]$. Để cung cấp các thông tin phuc vư cho quá trình chẩn đoán và điều trị cho bệnh nhân GIST, chúng tôi thực hiện nghiên cứu này với mục tiêu: Mô tả một số đặc điểm lâm sàng, cận lâm sàng và kết quả sớm điều trị phẫu thuẩt các trường hợp u mô đệm (GIST) của dạ dày tại khoa Ngoại - Bệnh viện Bạch Mai giai đoạn 2016-2020.

\section{II. ĐỐI TƯỢNG VÀ PHƯƠNG PHÁP NGHIÊN CỨU}

2.1. Đối tượng nghiên cứu. 50 bệnh nhân trên 18 tuổi, được điều trị phẫu thuật tại khoa Ngoại Bệnh viện Bạch Mai từ tháng 01 năm 2016 đến tháng 12 năm 2020, có khối u ở dạ dày trên nội soi, được chẩn đoán xác định bằng mô bệnh học là GIST và hóa mô miễn dịch dương tính với CD-117 và/hoặc CD34; loại trừ khỏi nghiên cứu bệnh nhân: có các ung thư đường tiêu hóa khác, có tiền sử mổ cắt da dày.

\subsection{Phương pháp nghiên cứu}

- Nghiên cứu mô tả loạt ca bệnh với cách chọn mẫu thuận tiện.

- Thu thập thông tin về các đặc điểm: lâm sàng (tiền sử nội ngoại khoa, triệu chứng lâm sàng (đau bụng, sốt, đại tiện phân đen, sờ thây khối u), chẩn đoán hình ảnh gồm nội soi dạ dày và chụp cắt lớp vi tính. Thông tin về phẫu thuật và kết quả điều trị: kỹ thuật mổ, thời gian mổ, thời gian trung tiện, thời gian nằm viện sau mố, tai biến và biến chứng chính.

- Tiêu chuẩn chẩn đoán u mô đệm dựa và giải phẫu bệnh: hóa mô miễn dịch CD117, CD34.

- Phân tích và xử lý số liệu: Sử dụng phần mềm SPSS 22.0, Test kiểm định: $\chi^{2}, T$ - test.

\section{KẾT QUẢ NGHIÊN CỨU}

Nghiên cứu trên 50 bệnh nhân với tuổi trung bình $56,3 \pm 12,6$ tuổi, thấp nhất là 33 tuổi và cao nhất là 86 tuổi, có 22 nam và 28 nữ, tỉ lệ nam/nữ là 0,79 .

\section{1. Đặc điểm lâm sàng và cận lâm sàng}

Bảng 1. Đặc điểm lâm sàng $(n=50)$

\begin{tabular}{|c|c|c|c|c|}
\hline \multicolumn{2}{|c|}{ Triệu chứng } & $\mathbf{n}$ & $\mathbf{\%}$ \\
\hline \multirow{4}{*}{$\begin{array}{c}\text { Đau } \\
\text { bụng }\end{array}$} & \multirow{3}{*}{ Vị trí } & Thượng vị & 41 & 87,2 \\
\cline { 3 - 5 } & Quanh rốn & 05 & 10,6 \\
\cline { 2 - 4 } & Tính & Hạ sườn trái & 01 & 2,1 \\
\cline { 2 - 4 } & chất & Lơ̂n & 29 & 61,7 \\
\cline { 2 - 4 } & \multicolumn{2}{|c|}{ Không đục } & 18 & 38,3 \\
\hline \multicolumn{3}{|c|}{ Gây sút cân } & 3 & 6,0 \\
\hline \multicolumn{2}{|c|}{ Đâyy bụng, chướng bụng } & 01 & 2,0 \\
\hline \multicolumn{3}{|c|}{ Nồn, buồn nôn } & 01 & 2,0 \\
\hline \multicolumn{3}{|c|}{ Đại tiện phân đen } & 01 & 2,0 \\
\hline \multicolumn{3}{|c|}{ Sờ thấy khối u } & 04 & 8,0 \\
\hline \multicolumn{3}{|c|}{ Thiếu máu } & 07 & 14,0 \\
\hline
\end{tabular}

Nhận xét: Đau bụng là triệu chứng lâm sàng phổ biển nhất $(94,0 \%)$, chủ yếu ở vùng thượng vị $(87,2 \%)$, phần nhiều đau thành cơn $(61,7 \%)$. Các triệu chứng khác đều gặp với tỉ lệ thấp.

Bảng 2. Hình ảnh nội soi dạ dày và cắt lớp vi tính $(n=50)$

\begin{tabular}{|c|c|c|c|c|}
\hline \multicolumn{3}{|c|}{ Đặc điếm } & \multirow{2}{*}{$\begin{array}{c}\mathbf{n} \\
24\end{array}$} & \multirow{2}{*}{$\begin{array}{c}\% \\
48,0\end{array}$} \\
\hline \multirow{8}{*}{$\begin{array}{c}\text { Nội } \\
\text { soi } \\
\text { dạ } \\
\text { dày }\end{array}$} & \multirow{2}{*}{$\begin{array}{c}\text { Niêm } \\
\text { mạc vị } \\
\text { trí khối u }\end{array}$} & Bình thường & & \\
\hline & & Loét, chảy máu & 26 & 52,0 \\
\hline & \multirow{6}{*}{ Vị trí u } & Thân vị & 13 & 26,0 \\
\hline & & Tâm vị & 07 & 14,0 \\
\hline & & Bờ cong lớn & 01 & 21,0 \\
\hline & & Bờ cong nhỏ & 04 & 8,0 \\
\hline & & Hang vị & 24 & 48,0 \\
\hline & & Môn vị & 01 & 2,0 \\
\hline \multirow{6}{*}{$\begin{array}{c}\text { Cắt } \\
\text { lớp } \\
\text { vi } \\
\text { tính }\end{array}$} & \multirow{4}{*}{ Khối u } & Kích thước (cm) & $9,2 \pm 9,0$ & $(2 \div 15)$ \\
\hline & & Bờ đều & 44 & 88,0 \\
\hline & & $\begin{array}{l}\text { Hoại tử trung } \\
\text { tâm }\end{array}$ & 02 & 4,0 \\
\hline & & $\begin{array}{l}\text { Ngấm thuốc } \\
\text { mạnh }\end{array}$ & 36 & 72,0 \\
\hline & \multirow[b]{2}{*}{ Di căn } & Dạ dày & 01 & 2,0 \\
\hline & & $\begin{array}{l}\text { Đại tràng } \\
\text { ngang }\end{array}$ & 02 & 4,0 \\
\hline
\end{tabular}


Tụy

\begin{tabular}{l|l}
01 & 2,0 \\
\hline
\end{tabular}

Nhân xét: Trên hình ảnh cắt lớp vi tính kích thước khối u trung bình 9,2 $\pm 9,0 \mathrm{~cm}$, nhỏ nhất là $2 \mathrm{~cm}$ và lớn nhất là $15 \mathrm{~cm}$ và có 4 trường hợp có biểu hiện di căn.

Bảng 3. Đặc điểm hóa mô miễn dịch $(n=50)$

\begin{tabular}{|c|c|c|}
\hline Đặc điếm & Tần số (n) & Tỷ lệ \% \\
\hline CD117 & 50 & 100,0 \\
\hline CD34 & 50 & 100,0 \\
\hline DOG1 & 46 & 92,0 \\
\hline Desmin & 18 & 36 \\
\hline SMA & 44 & 88,0 \\
\hline S100 & 8 & 16,0 \\
\hline CK & 7 & 14,0 \\
\hline
\end{tabular}

Nhận xét: Hai dấu ấn miền dịch CD117 và CD34 có ở tất cả các trường hợp.

3.2. Kết quả phẫu thuât

Bảng 4. Phương pháp phẫu thuật $(n=50)$

\begin{tabular}{|c|c|c|c|}
\hline $\begin{array}{c}\text { Phương pháp } \\
\text { phẩu thuật }\end{array}$ & Mổ mở & $\begin{array}{c}\text { Mố noôii } \\
\text { soi }\end{array}$ & Tổng \\
\cline { 2 - 4 } & $\mathbf{n ~ ( \% )}$ & $\mathbf{n ~ ( \% )}$ & $\mathbf{n ~ ( \% )}$ \\
\hline Cắt dạ dày hình & 26 & 12 & 38 \\
chêm & $(68,4)$ & $(100)$ & $(76,0)$ \\
\hline Cắt đoạn dạy dày & $08(21,1)$ & 0 & $08(16,0)$ \\
\hline Cắt dạ dày toàn bộ, & 04 & 0 & 04 \\
mở rộng & $(10,5)$ & 0 & $(8,0)$ \\
\hline Tổng & $\begin{array}{c}\mathbf{3 8} \\
(\mathbf{1 0 0})\end{array}$ & $\begin{array}{c}\mathbf{1 2} \\
\mathbf{( 1 0 0 )}\end{array}$ & $\begin{array}{c}\mathbf{5 0} \\
\mathbf{( 1 0 0 )}\end{array}$ \\
\hline
\end{tabular}

Nhân xét: 12 bênh nhân mố nôi soi được cắt da dày hình chêm, không có bệnh nhân nào mổ nội soi phải chuyển mổ mở.

Bảng 5. Kết quả sớm sau phẫu thuât $(n=50)$

\begin{tabular}{|c|c|c|}
\hline \multicolumn{3}{|c|}{ Diên biến sau mố } \\
\hline Thời gian (ngày) & Trung bình & Độ lệch \\
\hline Trung tiện & 1,9 & 0,7 \\
\hline Rút sonde dạ dày & 2,5 & 1,3 \\
\hline Cho ăn trở lại & 3,2 & 1,2 \\
\hline Thuốc giảm đau & 2,3 & 0,7 \\
\hline Nằm viện sau mố & 6,2 & 3,7 \\
\hline \multicolumn{3}{|c|}{ Tai biến và biến chứng } \\
\hline Tai biến, biến chứng & Tân số & Tỉ lệ \% \\
\hline Chảy máu trong mố & 02 & 4,0 \\
\hline Nhiềm trùng vết mố & 04 & 8,0 \\
\hline
\end{tabular}

Nhân xét: Có 2 trường hợp tai biến trong mổ là chảy máu và 4 trường hợp biến chứng sau mổ là nhiểm trùng vết mổ.

\section{BÀN LUẬN}

Kết quả nghiên cứu của chúng tôi cho thây đau bụng là triệu chứng lâm sàng phổ biến nhất ở bệnh nhân nghiên cứu (94,0\%). Các triệu chứng lâm sàng khác hiếm gặp hơn như thiếu máu $(14,0 \%)$, sờ thấy khối u $(8,0 \%)$, đại tiện phân đen $(8,0 \%)$, gầy sút cân $(2,0 \%)$.

Kết quả nghiên cứu của chúng tôi tương tự với kết quả của nhiều tác giả cho rằng phần lớn GIST không có triệu chứng và được phát hiện một cách tình cờ $[2,3]$. Trong nghiên cứu 35 bệnh nhân u mô đệm đường tiêu điều trị tại bệnh viện Bạch Mai, tác giả Mai Trọng Khoa ghi nhận triệu chứng đau bụng chiếm tỉ lệ nhiêu nhất, khoảng 2/3 số trường hợp [5]. Triệu chứng đau bụng có thể giải thích do sự phát triển nhanh của u gây chèn ép khoang phúc mạc hoặc do sự tiến triển xâm lấn các tạng lân cận, thậm chí có thể do u đã di căn gan hoặc phúc mạc. Kết quả tất cả bệnh nhân trong nghiên cứu của chúng tôi đều có triệu chứng khi đến khám bệnh. Chúng tôi nhận thấy, có nhiều bệnh nhân đau bụng ở những vị trí không tương xứng với khối u như đau bụng thành cơn quanh rốn hoặc đau bụng thay đổi vị trí kèm rối loạn đại tiện, đầy bụng, chướng bụng, đây có thể là triệu chứng của các bệnh lý khác kèm theo và cũng là nguyên nhân khiến bệnh nhân phải đi khám.

Ngoài ra, các lý do khác như triệu chứng của xuất huyết tiêu hóa (XHTH) hay sờ thấy khối u trong nghiên cứu của chúng tôi là hiếm gặp. Kết quả này thấp hơn so với nghiên cứu của Bùi Trung Nghĩa với tỉ lệ XHTH là 21,4\% [4]. Nguyên nhân có thể trong thời gian gần đây, $y$ tế tuyến cơ sở đặc biệt các bệnh viện tỉnh có nhiều tiến bộ. Nhiều bệnh nhân vào bệnh viện tuyến cơ sở để cấp cứu vì xuất huyết tiêu hóa được thực hiên phẫu thuật ngay tại đây, ít có bệnh nhân phải chuyển tuyến lên bệnh viện Bạch Mai.

Chụp cắt lớp vi tính (CLVT) được coi là phương tiện có giá trị chẩn đoán cơ bản đối với GIST; có giá trị cao không chỉ trong chẩn đoán mà còn trong theo dõi, đánh giá đáp ứng điều trị và tái phát sau mổ. Kết quả nghiên cứu của chúng tôi cho thấy, trên hình ảnh cắt lớp vi tính kích thước khối u trung bình 9,2 $\pm 9,0 \mathrm{~cm}$, trong đó nhỏ nhất là $2 \mathrm{~cm}$ và lớn nhất là $15 \mathrm{~cm}$. Kích thước u GIST trong nhiều nghiên cứu là khác nhau,với kích thước trung bình từ 4,4 đến 18,8 $\mathrm{cm}$ [6] [1]. Kích thước u trung bình trong nghiên cứu tại Litva năm 2014 của Poškus và cộng sự cũng chỉ 4,4 cm [2]. Kích thước khối u trong các nghiên cứu có sự khác biệt như vậy có thể do đối tượng nghiên cứu có sự khác biệt và sự phát triển của nội soi tiêu hóa của từng khu vực cũng khác nhau mà nội soi có vai trò quan trọng trong chẩn đoán sớm các khối u dạ dày. Về tính chất của khối u, trong nghiên cứu của chúng tôi, phần lớn khối u có bờ đều $(88,0 \%)$ và ngấm thuốc 
mạnh $(72,0 \%)$, ít có hoại tử trung tâm $(4,0 \%)$. Phát hiện di căn dạ dày $(2,0 \%)$, đại tràng ngang $(4,0 \%)$, tụy $(2,0 \%)$. Kết quả này tương đồng với nhiêu nghiên cứu của các tác giả khác [2],[4]. Theo đó, GIST nguyên phát thường là một khối tăng tỷ trọng đơn độc, ranh giới rõ, tăng sinh mạch và thường không đồng nhất do hoại tử trung tâm, chảy máu trong u hay thoái hóa nang ở thời điểm chẩn đoán. Tuy có giá trị cao trong phát hiện khối u, nhưng trên hình ảnh cắt lớp vi tính khó có thể phân biệt được u GIST da dày với khối u khác của vùng dạ dày, đặc biệt là ung thư da dày. Vì thế, cần có thêm những phương tiện khác hỗ trợ thêm giúp cho việc chẩn đoán u rõ ràng hơn, đặc biệt là nội soi và sinh thiết khối u.

Nội soi ống tiêu hóa bao gồm nội soi thực quản - dạ dày - tá tràng và nội soi đại trực tràng thường được tiến hành khi làm chẩn đoán ở những bệnh nhân đã có triệu chứng của hệ tiêu hóa như xuất huyết tiêu hóa, đau bụng, thiếu máu hay sờ thấy u trong ổ bụng. Nghiên cứu của chúng tôi cho thấy trên hình ảnh nội soi dạ dày các khối u có loét niêm mạc chảy máu $52,0 \%$. Vị trí khối u ở hang vị $48,0 \%$, thân vị $26,0 \%$, bờ cong lớn $21,0 \%$, tâm vị $14,0 \%$, bờ cong nhỏ $8,0 \%$, môn vị $2,0 \%$. Kết quả này tương tự như nhận xét về hình thái tổn thương trong nội soi của GIST được ghi nhận trong y văn $[1,4,5]$. Các tác giả đều thống nhất rằng do GIST phát triển từ thành ống tiêu hóa chứ không phải từ lớp niêm mạc nên hình ảnh nội soi thường thấy giống như khối đè đẩy từ ngoài vào. Tổn thương thường được bao phủ bởi một lớp niêm mạc bình thường, đôi khi có thể có loét, tăng sinh mạch hay chảy máu do u chèn ép gây thiếu máu cục bộ vùng niêm mạc ở vị trí tương ứng. Tuy nhiên, hình ảnh nội soi chỉ mang tính chất gợi ý chứ không thể phân biệt được GIST với các tổn thương ngoài niêm mạc khác như u lympho hay u cơ trơn. Như vậy, chẩn đoán xác định vẫn phải dưa vào kết quả giải phẫu bênh, một xét nghiệm có vai trò quyết định trong chẩn đoán bệnh $[1],[2],[3],[6]$.

Hóa mô miễn dịch được coi là tiêu chuẩn vàng để chẩn đoán phân biệt GIST với một số u trung mô khác của đường tiểu hóa. Trong nghiên cứu của chúng tôi, tất cả các bệnh nhân đều được xét nghiệm hóa mô miễn dịch $C D 117$ và các dấu ấn khác DOG1, CD34, Desmin, SMA, S100, CK. Kết quả nghiên cứu của chúng tối cho thấy tî lệ các dấu ấn miễn dịch dương tính với $\mathrm{CD} 117$ và $\mathrm{CD} 34$ đều $100 \%$, DOG1 92,0\%, SMA (88,0\%, Desmin 36,0\%, S100 16,0\%, CK 14,0\%. Nhiêuu nghiên cứu cho thấy tî lệ CD117 dương tính chiếm 90-95\%, CD34 dương tính 60 - 85\%, $30-40 \%$ dương tính với SMA, chỉ $5 \%$ dương tính với $S 100$, và $1-2 \%$ dương tính với Desmin [3]. Như vậy, kết quả nghiên cứu của chúng tôi cho thây các kết quả dương tính cao hơn với các dấu ấn miễn dịch; trong đó, DOG1 là một dấu ấn miễn dịch mới có giá trị rất cao trong chẩn đoán GIST, DOG1 được cho là nhạy hơn và đặc hiệu hơn cả CD117 [7] . Kết quả này có thể do sự phát triển của y học và trình độ chuyên môn của bác sĩ đem lại kết quả chính xác hơn trong chẩn đoán u GIST chính vì vậy tỉ lệ dương tính của các dấu ấn miễn dịch đặc hiệu cúng cao hơn.

Phẫu thuật vẫn là phương pháp có vai trò chủ đạo trong điều trị u GIST. Trong nghiên cứu của chúng tôi, có 5 bệnh nhân $(10,0 \%)$ được mổ cấp cứu, 45 bệnh nhân $(90,0 \%)$ mổ phiên. Trong 5 trường hợp mổ cấp cứu có 4 trường hợp do xuất huyết tiêu hóa và 1 trường hợp có biến chứng thủng dạ dày dẫn đến viêm phúc mạc. Tuy nhiên, sau khi phẫu thuật các trường hợp này đều cho kết quả điều trị tốt, không có trường hợp nào bị biến chứng nặng hay tử vong. Phần lớn bệnh nhân trong nghiên cứu của chúng tôi được mổ mở $76,0 \%$ và trong số $24 \%$ mổ nội soi khổng có bệnh nhân nào phải chuyển mổ mở. Trong thực tế, phương pháp phẫu thuật được lựa chọn phụ thuộc vào nhiều yếu tố như vị trí, kích thước khối u, tình trạng của bệnh nhân cũng như điều kiện trang thiết bị hiện có và khả năng, kinh nghiệm của phẫu thuật viên. Gần đây, phẩu thuật nội soi đang từng bước được chỉ định rộng rãi hơn nhưng còn hạn chế ở những trường hợp kích thước u lớn do nguy cơ làm võ u và phát tán tế bào ung thư vào ổ bụng $[1,8]$.

Trong nghiên cứu của chúng tôi, có 2 bệnh nhân $(4,0 \%)$ chảy máu trong mổ và không thấy các tai biến khác trong mổ. Trong 2 bệnh nhân này, chảy máu trong mổ do khối u lớn và dính vào các tạng, tuy nhiên cả 2 trường hợp đều được cầm máu tốt và không có nguy hiểm. Tỉ lê này cũng thấp hơn so với một số nghiên cứu về phâuu thuật dạ dày khác. Tai biến này có thể liên quan đến việc đánh giá trước mổ, đặc điểm khối u và trình đồ phẫu thuât viên. Đắc biệt chảy máu trong mổ có thể nguy hiểm với những bệnh nhân có bệnh lý tim mạch hoặc những bệnh nhân được mổ nội soi. Vì vậy, đánh giá các bệnh lý kèm theo và lựa chọn phương pháp phẫu thuật phù hợp là quan trọng ảnh hưởng đến kết quả phẫu thuật u GIST [1].

Trong nghiên cứu của chúng tôi, phần lớn bênh nhân trung tiện trở lại vào ngày thứ 1 đến ngày thứ 2 . Thời gian dùng thuốc giảm đau phần 
lớn trong 2 ngày đầu. Thời gian rút sonde dạ dày và cho ăn trở lại trung bình của bệnh nhân trong nghiên cứu là 2,5 ngày và 3,2 ngày. Như vậy, giống với các phẫu thuật đường tiêu hóa khác, thời gian có lại lưu thông ruột thường chậm hơn những phẫu thuật khác trong ổ bụng như cắt túi mật, cắt ruột thừa. Cho ăn trở lại càng sớm càng tốt khi tình trạng bệnh nhân ổn định và có lại lưu thông ruột là biện pháp hiệu quả giúp đảm bảo dinh dưỡng cho bệnh nhân và giảm thời gian nằm viện.

Tuy nhiên, kết quả lâu dài và tái phát của u GIST dạ dày còn chưa được đánh giá đầy đủ. Theo nghiên cứu của Chairat Supsamutchai và cộng sự cho thấy tỉ lệ tái phát là $29,4 \%$ với thời gian theo dõi là 32 tháng [8]. Vì vậy, cần có những nghiên cứu sâu hơn để đánh giá kết qua lâu dài của phẫu thuật u GIST dạ dày.

\section{KẾT LUÂN}

Bệnh nhân u mô đệm dạ dày thường có các triệu chứng lâm sàng không điển hình trong đó đau bụng là triệu chứng thường gặp nhất. Hình ảnh cắt lớp vi tính và nội soi dạ dày có giá trị cao trong chẩn đoán tuy nhiên chẩn đoán xác định phải dựa vào giải phẫu bệnh và hóa mô miễn dịch đặc biệt 2 dấu ấn CD117 và CD34. Phẫu thuật có kết quả sớm thường tốt, tuy nhiên về lâu dài cần theo dõi và đánh giá thêm.
1. Al-Kalaawy, M., et al., Gastrointestinal stroma tumors (GISTs), 10-year experience: Patterns of failure and prognostic factors for survival of 127 patients. Journal of the Egyptian National Cancer Institute, 2012. 24(1): p. 31-39.

2. Poškus, E., et al., Surgical management of gastrointestinal stromal tumors: a single center experience. Videosurgery and Other Miniinvasive Techniques, 2014. 9(1): 71-82.

3. Kang, Y.-K., et al., Clinical practice guideline for accurate diagnosis and effective treatment of gastrointestinal stromal tumor in Korea. Journal of Korean medical science, 2010. 25(11): p. 1543-1552.

4. Bùi Trung Nghĩa (2011), Đánh giá đặc điểm lâm sàng, câan lâm sàng và kêt quả điểu trị phấu thuật u mô đệm đường tiêu hóa (GIST) tai bênh viển Việt đức từ tháng 01/2005 - 12/2010. Luận văn tốt nghiêp bác sĩ nôii trú, Trường Đai hoc Y Hà Nội.

5. Mai Trọng Khoa, Trân Đình Hà, Phạm Cẩm Phương và cs (2014), Đánh giá hiệu quả của Imatinib (Glivec) trong điều trị U mô đệm đường tiêu hóa tại Trung tâm $Y$ học hạt nhân và Ung bướu - Bệnh viên Bach Mai, in Tạp chí Ung Thư hoc Việt Nam. 2014, tr. 41-47.

6. Diệp Bảo Tuấn (2016), Nghiên cứu chẩn đoán và điêuu trị bướu mô đệm đường tiêu hóa, Tạp chí Ung thư học Việt Nam. 2 (GIST), 7.

7. Phạm Minh Hải, Lê Quan Anh Tuấn, Võ Tấn Long và CS (2008), Đặc điểm lâm sàng, cận lâm sàng và kết quả điêu trị phẫu thuật u mồ đệm đường tiêu hóa. Tap chỉ Nghiên cứu Y học TP Hồ Chí Minh, 4 (Phụ bản số 4 ), 70.

8. Supsamutchai, C., et al. (2018), A cohort study of prognostic factors associated with recurrence or metastasis of gastrointestinal stromal tumor (GIST) of stomach. Annals of Medicine and Surgery, 35: p. 1-5.

\section{TÀI LIỆU THAM KHẢO}

\section{TỨ VẬT ĐÀO HỒNG THANG KẾT HỢP ĐIỆN CHÂM ĐIỀU TRI ĐAU THẮT LƯNG DO THOÁI HÓA CộT SỐNG}

\section{TÓM TẮT}

Mục tiêu: đánh giá hiệu quả giảm đau, cải thiện chức năng vận động cột sống trên bệnh nhân đau thắt lưng do thoái hóa cột sống bằng bài thuốc Tứ vật đào hồng thang kết hợp điện châm. Đối tượng và phương pháp: 68bệnh nhân được chẩn đoán đau thắt lưng do thoái hóa cột sống, không phân biệt giới tính, nghề nghiệp, tình nguyện tham gia nghiên cứu. Nhóm nghiên cứu điều trị bằng bài thuốc Tứ vật đào hồng thang kết hợp điện châm, nhóm đối chứng điêu

${ }^{1}$ Viện Y học cổ truyền Quân đội,

²Bềnh viện Châm cứu Trung ướng

Chịu trách nhiệm chính: Nguyễn Vinh Quốc

Email: quocnguyenvinh@gmail.com

Ngày nhận bài: 4/7/2021

Ngày phản biên khoa hoc: 30/7/2021

Ngày duyệt bài: 23/8/2021

\section{Nguyễn Vinh Quốc ${ }^{1}$, Nguyễn Đức Minh ${ }^{2}$}

trị bằng điện châm đơn thuân. So sánh kết quả trước và sau điều trị. Kết quả: Bài thuốc Tứ vật đào hồng thang kết hợp điện châm hiệu quả tốt trong điều trị đau thắt lưng do thoái hóa cột sống, $67,6 \%$ đat kết quả tốt. Điểm VAS tăng từ 1,62 (điểm) trước điêuu trị lên3,79 (điểm) sau điêu trị; độ giãn cột sống thắt lưng tăng từ 12,34 $(\mathrm{cm})$ trước điều trị lên 14,23 $(\mathrm{cm})$ sau điều trị; tâm vận động cột sống thắt lưng các động tác cải thiện tốt hởn có ý nghĩa so với trước điều trị và tốt hơn so với nhóm đối chứng. Kết luân: Bài thuốc Tứ vật đào hồng thang kết hợp điện châmhiệu quả tốt trong điều trị đau thắt lưng do thoái hóa cột sống.

Tư khóa: Tứ vật đào hồng thang, điện châm, thoái hóa cột sống thắt lưng

\section{SUMMARY \\ THE EFFECTS OF TREATMENT OF LOW BACK PAIN CAUSED BY DEGENERATIVE SPINE BY "TU VAT DAO HONG THANG" COMBINED WITH}




\section{ELECTRIC ACUPUNCTURE}

Objective: To evaluate the pain-relieved effect and improvement in spine motor function of Tu vat dao hong thang combined with electric acupuncture on the low back pain caused by degenerative spine. Subjects and methods: 68 patients diagnosed with degenerative spondylosis of lumbar spine, regardless of gender or occupation, were participated in the study. Researchers combined using Tu vat dao hong thangwith electric acupuncture, while the control group was treated with electric acupuncture only. Comparing the results before and after treatment.

Result: The low back pain caused by degenerative spine treating method by using the combination of $\mathrm{Tu}$ vat dao hong thang with electric acupuncture worked efficiency, $67.6 \%$ rate of good results. The VAS score increased from 1.62 (before the treatment) to 3.79after the study; the lumbar spinal dilation increased from $12,34 \mathrm{~cm}$ to $14,23 \mathrm{~cm}$ after the treatment; the lumbar spine movement improved better than before treatment and better than control group, difference was statistically significant. Conclusion: the treating method using Tu vat dao hong thang with electric acupuncture treatment is effective in treating low back pain caused by degenerative spine.

Keywords; Tu vat dao hong thang, electric acupuncture, degenerative lumbar spine.

\section{I. ĐĂT VẤN ĐỀ}

Đau thắt lưng do thoái hóa cột sống (THCS) là bệnh lý phổ biến, thường gặp trên lâm sàng vàcó xu hướng gia tăng trong xã hội hiện đại[1], [2]. Bệnh gặp ở mọi lứa tuổi, giới tính, nghề nghiêp lao động với biểu hiện lâm sàng cơ bản là đau[1],[2], [3]. Đau thắt lưng do THCS ảnh hưởng không tốt tới khả năng lao động, sinh hoạt của người bệnh hoặc để lại các di chứng nặng nề, tạo gánh nặng cho bản thân người bệnh, cho gia đình và xã hội nếu không được điều trị[1],[2], [3]. Do vậy lựa chọn phương án điều trị hiệu quả bệnh lý nàyvới thời gian và chi phí hợp lý, duy trì ổn định chức năng cột sống,hạn chế tái phát là vấn đề cần thiết, có ý nghĩa về khoa học y học cũng như ý nghĩa sâu sắc về măt xã hôi.

Theo Y học cổ truyên (YHCT), đau thắt lưng do THCSđược mô tả thuộc phạm trù "chứng tý"với bệnh danh yêu thống...[1], [2]. Có nhiều phương pháp điều trị bệnh lý này mang lại hiệu quả tốt trong đó có dùng thuốc kết hợp với các kỹ thuật điều trị không dùng thuốc[4], [5], [6]...

Tứ vật đào hồng thanglà bài thuốc cổ phương có tác dưng dưỡng huyết, hoat huyết, hoá ứ, lý khí chỉ thống[1], [7]; điện châmlà phương pháp điều trị có tác dụng giảm đau, giãn cơ thường được các thây thuốc YHCT áp dụng trong điều trị bệnh lý xương khớp và đã thu được những kết quả đáng khích lệ[4], [5],[6]... Để tăng cường hiệu quả điều trị, góp phần cải thiện chất lượng cuộc sống cho người bệnh, nghiên cứu được thực hiện nhằm mục tiêu đánh giá hiệu quả điều tri đau thắt lưng do THCS của bài thuốc Tứ vật đào hồng thang kết hợp điện châm.

\section{CHẤT LIỆU, ĐỐI TƯợNG VÀ PHƯƠNG PHÁP NGHIÊN CỨU}

\subsection{Chất liệu, phương tiện nghiên cứu}

- Bài thuốc cổ phương Tứ vật đào hồng thang (Xuyên khung12g, Bạch thược12g, Thục địa12g, Đương qui, $12 \mathrm{~g}$, Hồng hoa08g, Đào nhân $10 \mathrm{~g}$ ) [1]. Thuốc được sắc và đóng túi tự động 150 $\mathrm{ml} /$ túi, 02 túi/thang tại Viện YHCT Quân đội.

- Máy điện châm M8 do Bệnh viện chẩm cứu Trung ương sản xuất, Thước đo thang điểm VAS (Visual Analogue Scale); Thước đo góc vận động cột sống thắt lưng, thước dây.

- Kim châm cứu 1 lần các cõ̃, pince, bông, cồn $70^{\circ}$ và các dụng cụ cần thiết khác phục vụ yêu cầu kỹ thuật.

2.2. Đối tượng nghiên cứu. 68 bệnh nhân (BN) được chẩn đoán đau thắt lưng do THCS[1], không phân biệt tuổi, giới tính, nghề nghiệp, tình nguyện tham gia nghiên cứu. Điều trị tại Viện YHCT Quân đội và Bệnh viện Châm cứu Trung ương/Bộ Y tế từ tháng 6/2020 - tháng 12/2020. Không đưa vào nghiên cứu các BN có tổn thương da hoặc tổ chức dưới da vùng điều trị, lao cột sống, chấn thương cột sống, dị dạng cột sống, loãng xương nặng, suy gan, suy thận, suy tim, đái tháo đường.

2.3. Phương pháp nghiên cứu. Nghiên cứu tiến cứu, thử nghiệm lâm sàng mở, so sánh kết quả trước và sau điều trị có đối chứng. Chọn mẫu có chủ đích theo phương pháp ghép cặp đảm bảo tương đồng về tuổi, giới, nghề nghiệp, thời gian mắc bệnh, mức độ đau theo thang điểm VAS và các triệu chứng lâmm sàng khác. Các BN được chia thành 2 nhóm, mỗi nhóm 34 BN:

- Nhóm đối chứng (NDC): điều trị bằng điện châm theo phác đồ châm tả các huyệt Thận dú, Đại trường du, Thứ liêu, Trật biên, Yêu dương quan, Giáp tích L1-L5, Hoàn khiêu và châm bình bổ bình tả huyệt Uỷ trung bên đau[1], thời gian 20 phút/lần/ngày $x 15$ ngày.

- Nhóm nghiên cứu (NNC): điều trị như NĐC kết hợp bài thuốc Tứ vật đào hồng thang dạng sắc, ngày 2 túi chia 2 lần sáng - chiêu. Thời gian điềutrị như NĐC.

- Chỉ tiêu theo dõi và đánh giá:

+ Lâm sàng: lượng giá hiệu quả giảm đau theo thang điểm VAS; đánh giá hiệu quả cải thiện độ giãn cột sống thắt lưng bằng nghiệm pháp 
Schober; đánh giá hiệu quả cải thiện tầm vận động cột sống thắt lưng các động tác cúi, ngửa, nghiêng, xoay[3], [6]. Các chì tiêu theo dõi và đánh giá thực hiện tại thời điểm trước điều trị $\left(T_{0}\right)$, sau 7 ngày điêu trị $\left(T_{1}\right)$ và sau 15 ngày điêu trị $\left(\mathrm{T}_{2}\right)$.

+Kết quả điêu trị chung: tính tỷ lệ giảmtổng điểm dựa trên các chỉ tiêu VAS, Schober, tâm vận động cột sống thắt lưng các động tác sau điều trị so với trước điều trị, phân thành các loại kết quả tốt (tổng số điểm sau điều trị giảm $>80 \%$ so với trước điêuu trị); Khá (tổng số điểm sau điều trị giảm 65 -80\% so với trước điêu trị); Trung bình (tổng số điểm sau điêu trị giảm 50 $<60 \%$ so với trước điêuu trị); Không kết quả (tổng số điểm sau điêu trị giảm $<50 \%$ so với trước điều trị)[3],[4].

2.4. Xử lý số liệu. Số liệu được xử lý theo phương pháp thống kê y học theo chương trình SPSS 13.0 for Windows. Sử dụng các thuật toán:tính tỷ lệ phân trăm (\%); tính số trung bình; tính độ lệch chuẩn (SD);so sánh 2 giá trị trung bình dùng test $\mathrm{t}$ - student. Khác biệt có ý nghĩa khi $p<0,05$.

\section{KẾT QUẢ NGHIÊN CỨU}

3.1. Đặc điểm chung các đối tượng nghiên cứu

Bảng 1. Đăc điểm chung các đối tượng nghiên cứu

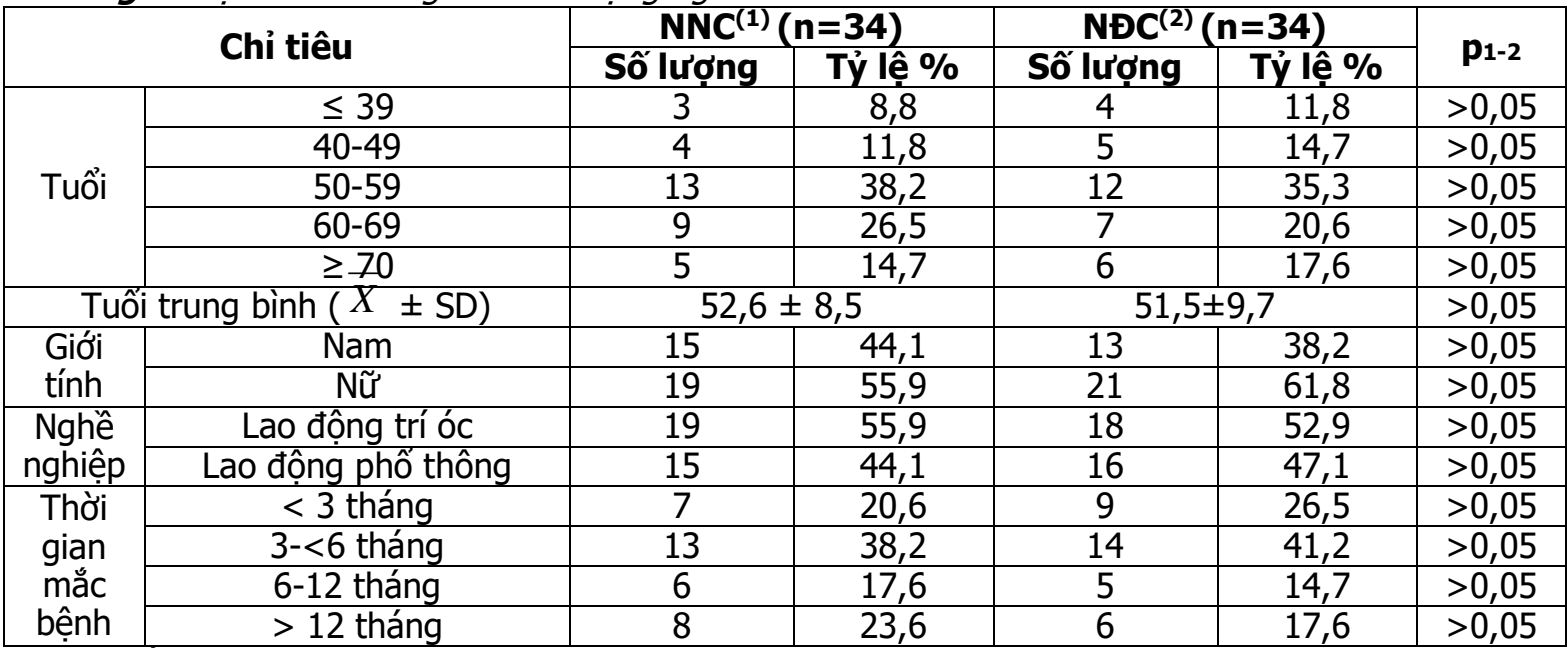

Độ tuối mắc bệnh trên 50 ở hai nhóm chiếm tỷ lệ cao (79,4\% ở NNC và 73,5\% ở NĐC). Nữ giớ mắc bệnh có xu hướng cao hơn nam giới (55,9\% ở NNC và $61,8 \%$ ở NĐC). Tỷ lệ đối tượng lao động trí óc và lao động phổ thông bị đau thắt lưng do THCS là tương đương. Thời gian mắc bệnh từ 3 tới 6 tháng chiếm tỷ lệ cao $(38,2 \%$ ở NNC và $41,2 \%$ ở NĐC). Chưa nhận thây khác biệt giữa các yếu tố tuổi, giới, nghề nghiệp và thời gian mắc bệnh giữa hai nhóm $B N$ nghiên cứu $(p>0,05)$.

\subsection{Kết quả điều trị}

Bảng 2. Hiệu quả cải thiên điểm đau VAS (điểm; $\bar{x} \pm S D$ )

\begin{tabular}{|c|c|c|c|}
\hline Thời điếm & $\operatorname{NNC}^{(1)}(n=34)$ & $\operatorname{NĐC}^{(2)}(n=34)$ & $\mathbf{p}_{1-2}$ \\
\hline$T_{0}(\mathrm{a})$ & $1,62 \pm 0,61$ & $1,88 \pm 0,69$ & $>0,05$ \\
\hline$T_{1}{ }^{(b)}$ & $2,71 \pm 0,46$ & $2,65 \pm 0,49$ & $>0,05$ \\
\hline $\mathrm{T}_{2}{ }^{(c)}$ & $3,79 \pm 0,41$ & $3,03 \pm 0,67$ & $<0,05$ \\
\hline $\mathrm{p}$ & Pa-b; pa-c; pb-c $_{2}<0,05$ & Pa-b; pa-c; pb-c $_{2}<0,05$ & \\
\hline
\end{tabular}

Mức đô giảm đau theo thang điếm VAS có xu hướng cải thiên qua các thời điểm theo dõi ở cả 2 nhóm $B N$, khác biệt tại thời điểm trước điều trị $\left(T_{0}\right)$ và sau điều trị $\left(T_{1} ; T_{2}\right)$ có ý nghĩa thống kê $(p<0,05)$. Hiệu quả giảm đau sau 15 ngày điều trị của NNC tốt hơn NDC $(p<0,05)$.

Bảng 3. Hiệu quả cải thiện độ giãn cột sông thăt lưng $(\mathrm{cm} ; \bar{X} \pm S D)$

\begin{tabular}{|c|c|c|c|}
\hline Thời điếm & $\operatorname{NNC}^{(1)}(n=34)$ & $N^{\prime} C^{(2)}(n=34)$ & $\mathbf{p}_{1-2}$ \\
\hline$T_{0}(\mathrm{a})$ & $12,34 \pm 0,68$ & $12,66 \pm 1,31$ & $>0,05$ \\
\hline $\mathrm{T}_{1}{ }^{(\mathrm{b})}$ & $13,35 \pm 0,51$ & $13,19 \pm 0,53$ & $>0,05$ \\
\hline $\mathrm{T}_{2}(\mathrm{c})$ & $14,23 \pm 0,52$ & $13,75 \pm 0,38$ & $<0,05$ \\
\hline $\mathrm{p}$ & $\mathrm{p}_{a-b} ; \mathrm{p}_{a-c ;} \mathrm{p}_{\mathrm{b}-\mathrm{c}}<0,05$ & $\mathrm{p}_{a-b} ; \mathrm{p}_{a-c ;} \mathrm{p}_{\mathrm{b}-\mathrm{c}}<0,05$ & \\
\hline
\end{tabular}

Độ giãn cột sống thắt lưng trung bình ở cả hai nhóm BN tăng dần qua các thời điềm đánh giá, 
khác biệt trước và sau điều trị có ý nghĩa với $p<0,05$. Mức độ cải thiện độ giãn thắt lưng tại thời điểm sau 15 ngày điều trị̂̉ NNC tốt hơn NĐC $(p<0,05)$.

Bảng 4. Cải thiện tầm vận động cột sống thắt lưng các động tác (độ; ${ }^{\bar{x}}$ ISD)

\begin{tabular}{|c|c|c|c|c|}
\hline Động tác & Thời điếm & $\operatorname{NNC}^{(1)}(n=34)$ & $\operatorname{NDC}^{(2)}(n=34)$ & $\mathbf{p}_{1-2}$ \\
\hline \multirow{4}{*}{ Cúi } & $T_{0}(\mathrm{a})$ & $49,65 \pm 11,42$ & $49,65 \pm 10,71$ & $>0,05$ \\
\hline & $T_{1}{ }^{(b)}$ & $59,68 \pm 8,68$ & $57,03 \pm 9,27$ & $>0,05$ \\
\hline & $\mathrm{T}_{2}{ }^{(\mathrm{c})}$ & $67,06 \pm 6,54$ & $64,03 \pm 7,29$ & $<0,05$ \\
\hline & $\mathrm{p}$ & $\mathrm{P}_{\mathrm{a}-\mathrm{b}} ; \mathrm{P}_{\mathrm{a}-\mathrm{c}} ; \mathrm{p}_{\mathrm{b}-\mathrm{c}}<0,05$ & $\mathrm{p}_{\mathrm{a}-\mathrm{b}} ; \mathrm{P}_{\mathrm{a}-\mathrm{c}} ; \mathrm{p}_{\mathrm{b}-\mathrm{c}}<0,05$ & \\
\hline \multirow{4}{*}{ Ngửa } & $T_{0}{ }^{(a)}$ & $14,01 \pm 2,73$ & $14,18 \pm 3,06$ & $>0,05$ \\
\hline & $\mathrm{T}_{1}(\mathrm{~b})$ & $18,79 \pm 3,47$ & $18,21 \pm 3,44$ & $>0,05$ \\
\hline & $\mathrm{T}_{2}(\mathrm{c})$ & $23,95 \pm 2,37$ & $22,26 \pm 2,98$ & $<0,05$ \\
\hline & $\mathrm{p}$ & $\mathrm{p}_{\mathrm{a}-\mathrm{b}} ; \mathrm{p}_{\mathrm{a}-\mathrm{c} ;} ; \mathrm{p}_{\mathrm{b}-\mathrm{c}}<0,05$ & $\mathrm{p}_{\mathrm{a}-\mathrm{b}} ; \mathrm{p}_{\mathrm{a}-\mathrm{c}} ; \mathrm{p}_{\mathrm{b}-\mathrm{c}}<0,05$ & \\
\hline \multirow{4}{*}{ Nghiêng } & $T_{0}(a)$ & $19,13 \pm 2,97$ & $19,25 \pm 2,78$ & $>0,05$ \\
\hline & $T_{1}{ }^{(b)}$ & $22,53 \pm 2,96$ & $22,04 \pm 3,31$ & $>0,05$ \\
\hline & $T_{2}{ }^{(c)}$ & $27,85 \pm 3,12$ & $25,29 \pm 3,52$ & $<0,05$ \\
\hline & $\mathrm{p}$ & $\mathrm{p}_{a-b} ; \mathrm{p}_{\mathrm{a}-\mathrm{c} ;} ; \mathrm{p}_{\mathrm{b}-\mathrm{c}}<0,05$ & $\mathrm{p}_{a-b} ; \mathrm{p}_{\mathrm{a}-\mathrm{c}} ; \mathrm{p}_{\mathrm{b}-\mathrm{c}}<0,05$ & \\
\hline \multirow{4}{*}{ Xoay } & $T_{0}(a)$ & $13,94 \pm 2,33$ & $12,71 \pm 2,67$ & $>0,05$ \\
\hline & $T_{1}(\mathrm{~b})$ & $18,85 \pm 3,06$ & $17,32 \pm 3,48$ & $>0,05$ \\
\hline & $\mathrm{T}_{2}{ }^{(\mathrm{c})}$ & $23,97 \pm 2,89$ & $22,29 \pm 4,15$ & $<0,05$ \\
\hline & $\mathrm{p}$ & $\mathrm{p}_{\mathrm{a}-\mathrm{b}} ; \mathrm{P}_{\mathrm{a}-\mathrm{c}} ; \mathrm{P}_{\mathrm{b}-\mathrm{c}}<0,05$ & $\mathrm{p}_{\mathrm{a}-\mathrm{b}} ; \mathrm{p}_{\mathrm{a}-\mathrm{c}} ; \mathrm{p}_{\mathrm{b}-\mathrm{c}}<0,05$ & \\
\hline
\end{tabular}

Tầm vận động cột sống thắt lưng trung bình các động tác ở cả hai nhóm BN tăng dần qua các thời điểm đánh giá, khác biệt trước và sau điều trị có ý nghĩa thống kê $(p<0,05)$. Mức độ cải thiện tầm vận động cột sống thắt lưng các tư thế cúi, ngửa, nghiêng, xoay sau 15 ngày điều trị̛̉ NNC tốt hơn NĐC $(p<0,05)$.

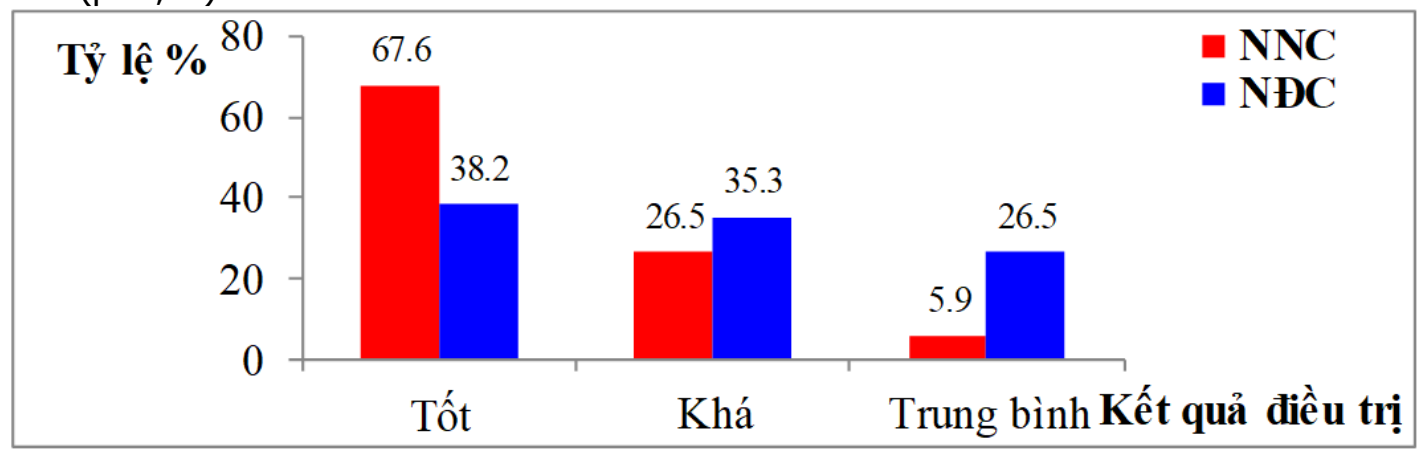

Biểu đồ 1. Hiệu quả chung sau 15 ngày điều trị

Tất cả BN ở hai nhóm nghiên cứu đều đáp ứng với điều trị ở các mức độ khác nhau sau 15 ngày điều trị. Tỷ lệ BN đạt kết quả điều trị tốt ở NNC cao hơn NĐCtrong khi tỷ lệ đáp ứng điều trị ở mức trung bình thấp hơn, khác biệt có ý nghĩa với $p<0,05$.

\section{BÀN LUẬN}

4.1. Đăc điểm chung các đối tượng nghiên cứu. Về tuổi và độ tuổi mắc bệnh, kết quả cho thấy cho thấy tuổi trung bình các $\mathrm{BN}$ NNC là $52,6 \pm 8,5$ và NĐC là $51,5 \pm 9,7$ (tuổi); $79,4 \%$ BN NNC và $73,5 \%$ BN NĐC có độ tuổi trên 50 . Kết quả này phù hợp với nhận định của Hồ Hữu Lương cũng như một số tác giả khác: THCS thắt lưng là bệnh mạn tính gặp chủ yếu ở người trung niên và người cao tuổi[2],[3],[4]... Nguyễn Đức Minh (2018) nhận thấy tuổi trung bình các $\mathrm{BN}$ đau thắt lưng do THCS điều trị tại Khoa Lão khoa/Bêenh viện Châm cứu Trung ương là $50,5 \pm 13,8$ (tuổi) [2], trong khi đó kết quả này trong nghiên cứu của Lê Thị Kim Dung và cộng sự (2018) là 52,3 \pm 10,7 (tuổi)[5]. Theo lý luận YHCT, phụ nữ 35 tuổi, nam giới 49 tuổi thiên quý bắt đâu suy; nữ đến 49 tuổi, nam đến 56 tuổi thiên quý kiệt, không nuôi được thận tinh, thận âm hư không nuôi được cốt tủy, cốt tủy không sinh huyết nên khí huyết hư suy. Công năng tạng phủ, khí huyết hư suy, dinh vệ, tấu lý sơ hở... tà khí ở bên ngoài như phong tà, hàn tà, thấp tà dễ xâm nhập gây nên bệnh [1],[2].

Về giới tính, tỳ lệ nữ giới mắc bệnh có xu hướng cao hơn nam giới (55,9\% ở NNC và $61,8 \%$ ở NĐC). Nhiều nghiên cứu cho rằng tỷ lệ nữ bị THCS thắt lưng nhiêu hơn nam do sự thay 
đổi hormon, đặc biệt sự thiếu hụt hormon estrogen sau mã̉n kinh, làm giảm khả năng hấp thu canxi - thành phần quan trọng tham gia cấu tạo đĩa đệm và xương khớp. Mặt khác cũng có thể do phụ nữ có ý thức quan tâm tới sức khỏe bản thân hơn nên tới khám và điều trị ngay khi mới xuất hiện triệu chứng bệnh[2],[3],[5],[6].

Về nghề nghiệp, có $55,9 \%$ là lao động trí óc và 44,1\% đối tượng là lao động phổ thông. Có thể thấy tỷ lệ mắc bệnh ở hai nhóm nghề nghiệp là tương đương, phù hợp với nhận định của nhiều tác giả - thoái hóa khớp trong đó THCS thắt lưng là một bệnh mạn tính xảy ra ở mọi thành phần của xã hội [2], [3],[6]...

$38,2 \% \mathrm{BN} N \mathrm{NC}$ và $41,2 \% \mathrm{BN} N D C$ có thời gian mắc bệnh từ 3 tới 6 tháng, tương tự nhận định Nguyễn Đức Minh (2018) khi đánh giá tình trạng đau thắt lưng do THCS Bệnh viện Châm cứu Trung ương $-33,3 \% \mathrm{BN}$ có thời gian mắc bệnh từ 3 tới 6 tháng[2]. Kết quả này phù hợp với nhận định của Hồ Hữu Lương cũng như một số nghiên cứu khác về hoàn cảnh xuất hiện cũng như tính chất khởi phát của đau thắt lưng do THCS, BN thường xuất hiện bắt đầu với đau mỏi vùng thắt lưng, do vậy có một tỷ lệ nhất định thích ứng dần với trạng thái đau mỏi, phần lớnngười bệnh thường cố chịu đựng hoặc tự điều trị tại nhà, chỉ tới cơ sở y tế để được chăm sóc khi đau không thể chịu đựng được nữa hoặc bệnh gây ảnh hưởng nhiều tới chức năng sinh hoạt hàng ngày[3]. Điêuu này cũng phản ánh trình độ hiểu biết và mức độ quan tâm của người bệnh đối với tình trạng thoái hóa khớp nói chung trong đó THCS thắt lưng chưa thực sự cao. Do vậy việc tăng cường giáo dục cộng đồng trong dự phòng và điều trị THCS thắt lưng là hết sức cần thiết và có ý nghĩa.

4.2. Kết quả điêu trị. Trong THCS thắt lưng, đau là triệu chứng chính khiến người bệnh phải tới bệnh viện khám và điều trị. Đau dẫn tới tình trạng co cứng cơ cạnh sống; sự co kéo của các gân, cớ, dây chằng và tư thế giảm đau làm hạn chế vận động cột sống thắt lưng, giảm hoặc mất chức năng sinh hoạt hàng ngày và tạo ra vòng xoắn bệnh lý[1],[3]. Do vậy trong điều trị, giải quyết được triệu chứng đau sẽ góp phần cải thiện được chức năng vận động của cột sống thắt lưng[1],[3],[4], [5],[6]...

Kết quả nghiên cứu cho thấy mức độ đau theo thang điểm VAS có xu hướng giảm dần qua các thời điểm theo dõi, khác biệt giữa thời điểm trước điều trị và sau điêu trị có ý nghĩa thống kê, hiệu quả giảm đau sau 15 ngày điều trị của NNC tốt hớn có ý nghĩa so với NĐC.Kết quả này cho thấybài thuốc Tứ vật đào hồng thang kết hợp điện châmcó tác dụng giảm đautrên các $B N$ đau thắt lưng do THCS. Theo nhận định của chúng tôi, hiệu quả này đạt được là do tác dụng kép: một mặt làtác dụng dưỡng huyết, hoạt huyết, hoá ứ, lý khí chỉ thốngcủa bài thuốc nghiên cứu[7], kết quả nghiên cứu hiện đại nhận thấy $5 / 6$ vị thuốc trong thành phần bài thuốc Tứ vật đào hồng thang chứa hoạt chất $\beta$-sitosterol có tác dụng giảm đau, chống viêm, hầu hết các vị thuốc đều chứa nhiều saponin, riêng Bạch thược có triterpen - một saponin có tác dụng tăng lực tương tự nhân sâm. Các vị thuốc xuyên khung, đương quy, đào nhân có nhiều tinh dâu thớm dế bay hơi, tác dụng rất tốt vào quá trình đông máu; hồng hoa, đào nhân có tác dụng chống kết tập tiểu cầu. Đặc biệt hầu hết các vị thuốc đều chứa nhiêu axít amin quý và các nguyên tố vi lượngrất cần thiết cho quá trình chuyển hóa đạm, đường, mõ̃, thực chất là tác dụng thúc đẩy chuyển hóa base purin, chuyển hóa năng lượng bù đắp, bổ xung lượng ATP đã bị tiêu hao nhiều trong quá trình lao động trí óc và thể lực, sốt, đau kéo dài...[7]. Mặt khác, thông qua tác động tại chô̂, phản ứng tiết đoạn và phản ứng toàn thân của điện châm đã kích thích phản ứng cơ thể làm giảm hàm lượng Cathecholamin, tăng hàm lượng Achetylcholin và làm sản sinh Endorphin nội sinh [8], từ đó đã giúp tăng cường hiệu quả giảm đau của phương pháp.

Hiệu quả giảm đau của bài thuốc Tứ vật đào hồng thang kết hợp điện châmđã giúp cải thiện các chỉ tiêu đánh giá chức năng vận động cột sống thắt lưng kèm theo trên các $B N$ nghiên cứu. Độ giãn cột sống thắt lưng trung bình, tầm vận động cột sống thắt lưng trung bình các tư thế ở cả hai nhóm BN đều cải thiện có ý nghĩa qua các thời điểm đánh giá, mức độ cải thiện của các chỉ tiêu này sau 15 ngày điều triở NNC tốt hơn có ý nghĩa so với NĐC (bảng 3, bảng 4). Kết quả thu được trong nghiên cứu này của chúng tôi cũng phù hợp với nhận định của một số nghiên cứu trước đớ: hiệu quả cải thiện chức năng vận động cột sống trên các trường hợp đau thắt lưng do THCS tỷ lệ thuận với mức độ giảm đau[3], $[4],[6] \ldots$

Về hiệu quả điều trịchung, sau 15 ngày điều trị tỷ lệ $B N$ đạt kết quả điều trị tốt ở NNC $(67,6 \%)$, cao hơn có ý nghĩa so với NĐC $(38,2 \%)$. Trong khi đó tỳ lệ đáp ứng điều trị ở mức trung bình ở NNC là $5,9 \%$, thấp hơn so với NĐC $(26,5 \%)$. Kết quả này phù hợp với nghiên cứu của Phạm Thị Ngọc Bích (2016), Trịnh Thị Hạnh (2018) khi kết hợp điện châm với thuốc 
YHCT điều tri đau thắt lưng do THCS[4],[6].Theo chúng tôi, với tác dụng điêu khí, giúp lưu thông khí huyết nơi kinh lạc bị bễ tắc, thúc đẩy quá trình sản sinh Endorphin nội sinh của điện châm kết hợp với tác dụng hoạt huyết hoá ứ, lý khí chỉ thống của bài thuốc Tứ vật đào hồng thang đã góp phần tạo nên hiệu quả điều trị tốt ở các $B N$ NNC cao hơn có ý nghĩa so với sử dụng điện châm đơn thuần.

\section{KẾT LUÂNN}

Bài thuốc Tứ vật đào hồng thang kết hợp điện châmhiệu quả tốt trong điều trị đau thắt lưng do thoái hóa cột sống:94,1\% đạt hiệu quả tốt và khá sau điều trị. VAS tăng từ $1,62 \pm$ 0,61 (điểm) trước điều trị lên còn $3,79 \pm 0,41$ (điểm) sau điều trị; độ giãn cột sống thắt lưng tăng từ $12,34 \pm 0,68(\mathrm{~cm})$ trước điều trị lên $14,23 \pm 0,52(\mathrm{~cm})$ sau điều trị. Tầm vận động cột sống thắt lưng trung bình các động tác tăng có ý nghĩa so với trước điêu trị.

\section{TÀI LIÊU THAM KHẢO}

1. Bộ Y tế (2020). Đau cột sống thắt lưng (Yêu thống). Hướng dẫn chẩn đoán và điêu trị bệnh theo y học cổ truyền, kết hợp y học cổ truyền với y học hiện đại, Nhà xuất bản Y học, Hà Nôi, 7-14.

2. Nguyến Đức Minh, Nguyễn Vinh Quốc (2018). Đánh giá tình trạng đau thắt lưng do thoái hóa cột sống trên bênh nhân điều tri tại Khoa Lão khoa, Bệnh viện Châm cứu Trung ương. Tạp chí Y dược lâm sàng $108,13(4), 87-92$.

3. Hồ Hữu Lương (2012). Đau thắt lưng và thoát vị đĩa đệm, Nhà xuất bản $Y$ hoc, Hà Nôi.

4. Trịnh Thị Hanh, Phạm Xuân Phong (2018) Điện châm kểt hợp thuốc Hoàn chỉ thông điêu trị thoái hóa côtt sống thắt lưng theo thể bênh $Y$ hoc cổ truyền. Tạp chí Y dược học cổ truyền Quân sự, 3(8), 46-53.

5. Lê Thị Kim Dung, Nguyễn Quang Dương, Đoàn Thị Nhung (2018). Nghiên cứu tác dụng giảm đau của bài thuốc TK1 kết hợp điên châm điều trị đau thắt lưng do thoái hóa cột sống thắt lưng. Tạp chí Y dược cổ truyền Việt Nam, 6(19), 31-38.

6. Pham Thị Ngọc Bích, Lê Thành Xuân (2016). Hiểu quả lâm sàng trong điều tri đau thắt lưng do thoái hóa côtt sống bằng điện trường châm kết hợp với bài thuốc độc hoat tang ký sinh. Tap chí nghiền cứu y học, 103(5), 32-39.

7. 周慎 và '何清湖 (2004). 止痛本草, 中医古籍出版社，北京.

8. Bộ môn $\mathbf{Y}$ học cố truyên - Trường đại học $Y$ Hà Nô̂i (2005). Châm cứu, NXB Y họ, Hà Nội.

\section{KẾT QUẢ ĐIỀU TRI PHẪU THUÂTT VIÊM MÀNG NGOÀI TIM CO THẮT TẠI BỆNH VIỆN HỮU NGHI VIỆT ĐỨC}

\section{Bùi Thanh Hùng ${ }^{2}$, Đoàn Quốc Hưng ${ }^{1,2}$, Đinh Văn Lượng ${ }^{3}$}

\section{TÓM TẮT}

Mục tiêu: Mô tả đặc điểm lâm sàng, cận lâm sàng của viềm màng ngoài tim co thắt và nhận xét kết quả phẫu thuật viêm màng ngoài tim co thắt tại bệnh viện Hữu nghị Việt Đức. Đối tượng và phương pháp: Nghiên cứu hồi cứu mô tả nhữ̛̃ng bênh nhân viêm màng ngoài tim co thắt được phẩu thuật tại trung tâm Tim mạch và lồng ngực Bệnh viện Hữu Nghị Việt Đức từ tháng 1/2014 đến tháng 12/2020. Kết quả: Có 14 bệnh nhân, trong đó 9 bệnh nhân nam $(64,3 \%)$. Độ tuổi trung bình là $47 \pm 19,8$. Nguyên nhân bênh là lao gặp ở 6 bệnh nhân $(42,9 \%)$, còn 8 bệnh nhẩn là viêm không đăc hiêu (57,1 \%). Tất cả bênh nhân đều được phẫu thuật cắt màng ngoài tim rộng rãi với đường mổ giữa xương ức. Thời gian mổ trung bình $175 \pm 31,3$ phút. Không có tử vong sau mổ và $100 \%$ có tình trạng

\footnotetext{
${ }^{1}$ Bệnh viện Hữu Nghị Việt Đức,

¿Đại học Y Hà Nôi,

${ }^{3}$ Bệnh viện Phổi Trung ương

Chịu trách nhiệm chính: Đoàn Quốc Hưng,

Email: hung.doanquoc@gmail.com.

Ngày nhận bài: 9/7/2021

Ngày phản biên khoa họ: 28/7/2021

Ngày duyệt bài: 24/8/2021
}

khó thở giảm đi ít nhất một bậc theo phân độ của hiệp hội Tim mạch New York (NYHA). Kết luận: Viêm màng ngoài tim co thắt là một bênh không thường gặp gây nên bởi sự dày dính và vôi hóa màng ngoài tim. Phẫu thuật cắt màng tim rộng rãi mang lại hiệu quả điều trị cao và an toàn.

Tứ khóa: Viêm màng ngoài tim, co thắt, phẫu thuật cắt màng tim, lao, viêm màng ngoài tim dày dính.

\section{SUMMARY}

RESULTS OF PERICARDECTOMY FOR

CONSTRICTIVE PERICARDITIS AT VIET DUC UNIVERSITY HOSPITAL

Objectives: To describe clinical and subclinical presentations of constrictive pericarditis and access results of pericardectomy for constrictive pericarditis at Viet Duc university hospital. Material and method: This is a retrospective, descriptive study of patients who underwent pericardiectomy for constrictive pericarditis at Cardiovascular and Thoracic center, Viet Duc University Hospital from 1/2014 to 12/2020. Result: There were 14 patients in total, nine were male $(64,3 \%)$. The mean age was $47 \pm 19,8$. Etiology of constrictive pericarditis was tuberculosis in 6 patients $(42,9 \%)$ and idiopathic for the remains $(57,1 \%)$. Extensive pericardectomy was performed in all patients with median sternotomy. The mean 
operative time was $175 \pm 31,3$ min. There was no inhospital mortality and all of patients improved at least one New York Heart Association (NYHA) functional class after surgery. Conclusion: Constrictive pericarditis is a rare disease that can result in chronic fibrous thickening of the pericardium. The use of pericardectomy for constrictive pericarditis was effective and safe.

Keyword:

Pericarditis,

constrictive, pericardectomy, tuberculous, adhesive pericarditis.

\section{I. ĐẶT VẤN ĐỀ}

Viêm màng ngoài tim co thắt đã được đề cập đến cách đây nhiều thế kỉ. Bệnh biểu hiện chủ yếu bởi sự chèn ép tim phải mà nguyên nhân là do sự xơ hóa, dày lên của màng ngoài tim. Đây là một bệnh không thường gặp. Mặc dù đã được đề cập đến từ lâu nhưng cơ chế bệnh sinh của viêm màng ngoài tim co thắt vẫn được cho là rất phức tạp, với nhiều yếu tố liên quan. Các triệu chứng lâm sàng và cận lâm sàng đôi khi không rõ ràng đặc biệt là giai đoạn sớm của bệnh. Phẫu thuật cắt màng tim rộng rãi được xem như là phương pháp điều trị chính. Tại Việt Đức, chúng tôi đã có kinh nghiệm nhiêu năm thực hiện phẫu thuật này. Vì vậy, chúng tôi làm nghiên cứu này nhằm mô tả đặc điểm lâm sàng, cận lâm sàng và nhận xét kết quả điều trị phẫu thuật viêm màng ngoài tim co thắt.

\section{II. ĐỐI TƯƠNGG VÀ PHƯƠNG PHÁP NGHIÊN CỨU}

Nghiên cứu hồi cứu mô tả những bệnh nhân viêm màng ngoài tim co thắt được phẫu thuật tại Trung tâm tim mạch và lồng ngực Bệnh viện Hữu Nghị Việt Đức từ tháng 1/2014 đến tháng 12/2020.

\section{KẾT QUẢ NGHIÊN CỨU}

Có 14 bệnh nhân trong đó có 9 nam $(64,3 \%)$

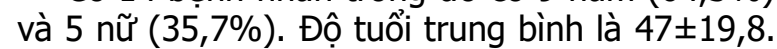
Các lý do vào viện gồm có: Khó thở (100\%), đau ngực $(64,3 \%)$, ho $(14,3 \%)$, cổ chướng $(7,1 \%)$, phù hai chân $(7,1 \%)$ và phù toàn thân $(7,1 \%)$.

Bảng 1. Triệu chứng lâm sàng $(N=14)$

\begin{tabular}{|c|c|c|}
\hline Triệu chứng lâm sàng & $\mathbf{N}$ & Tỷ lệ (\%) \\
\hline Khó thở & 14 & 100 \\
\hline Đau ngực & 7 & 50 \\
\hline Gan to & 9 & 64,3 \\
\hline Phù chi dưới & 5 & 35,7 \\
\hline Cố trướng & 4 & 28,6 \\
\hline Tĩnh mạch cố nối & 4 & 28,6 \\
\hline Ho & 2 & 14,3 \\
\hline
\end{tabular}

Bảng 2. Triệu chứng cận lâm sàng (N=14)

\begin{tabular}{|c|c|c|c|}
\hline \multirow{2}{*}{ Xquang } & Hình ảnh & $\mathbf{N}$ & $\begin{array}{c}\text { Tỳ lề } \\
(\mathbf{\%})\end{array}$ \\
\cline { 2 - 4 } & Vôi hóa màng tim & 5 & 35,7 \\
\hline & Bóng tim to & 10 & 71,4 \\
\hline
\end{tabular}

\begin{tabular}{|c|c|c|c|c|}
\hline & \multicolumn{2}{|c|}{ Chỉ số tim ngực } & \multicolumn{2}{|c|}{$55,5 \pm 7,5$} \\
\hline \multirow{8}{*}{$\begin{array}{l}\text { Siêu âm } \\
\text { tim }\end{array}$} & \multicolumn{2}{|c|}{ Tràn dịch màng tim } & 9 & 64,3 \\
\hline & \multicolumn{2}{|c|}{ Chèn ép thất phải } & 3 & 21,4 \\
\hline & \multicolumn{2}{|c|}{ Dày màng tim } & 14 & 100 \\
\hline & \multicolumn{2}{|c|}{ Vôi hóa màng tim } & 11 & 78,6 \\
\hline & \multirow{4}{*}{$\begin{array}{c}\text { Áp lực } \\
\text { động } \\
\text { mạch phổi }\end{array}$} & Tăng cao & 1 & 7,1 \\
\hline & & Tăng vừa & 6 & 42,9 \\
\hline & & Tăng nhẹ & 5 & 35,7 \\
\hline & & Không tăng & 2 & 14,3 \\
\hline \multirow{2}{*}{$\begin{array}{c}\text { Cắt lớp vi } \\
\text { tính }\end{array}$} & \multicolumn{2}{|c|}{ Dày màng tim } & 14 & 100 \\
\hline & \multicolumn{2}{|c|}{ Tràn dịch màng tim } & 7 & 50 \\
\hline
\end{tabular}

Trong mổ, không có bệnh nhân nào phải sử dụng tuân hoàn ngoài cơ thể (CPB). Thời gian mổ trung bình là $175 \pm 31,3$ phút, trong đó ngắn nhất là 120 phút, dài nhất là 230 phút. Tất cả bệnh nhân được phẫu thuật cắt màng tim rộng rãi với đường mổ giữa xương ức.

Bảng 3. Một số chi số trong và sau mổ $(N=14)$

\begin{tabular}{|c|c|c|}
\hline Chỉ số nghiên cứu & $\begin{array}{c}\text { Số bệnh } \\
\text { nhẩn }\end{array}$ & $\begin{array}{c}\text { Tỉ lệ } \\
\text { (\%) }\end{array}$ \\
\hline Viêm phối & 1 & 7,1 \\
\hline Suy thận & 1 & 7,1 \\
\hline Suy đa tạng & 0 & 0 \\
\hline Đột quy. & 0 & 0 \\
\hline Ngưnng tuâan hoàn & 0 & 0 \\
\hline Nhiếm khuấn huyết & 0 & 0 \\
\hline Chảy máu trong mố phải \\
truyền máu
\end{tabular}

Bảng 4. Mức độ NYHA trước và sau mổ $(N=14)$

\begin{tabular}{|c|c|c|c|c|c|}
\hline \multirow{2}{*}{ NYHA } & \multicolumn{2}{|c|}{ Trước mố } & \multicolumn{2}{c|}{ Sau mố } & \multirow{2}{*}{ p } \\
\cline { 2 - 5 } & $\mathbf{n}$ & $\mathbf{0}$ & $\mathbf{n}$ & $\mathbf{\%}$ & \\
\hline I & 0 & 0 & 10 & 71,4 & \multirow{2}{*}{0,} \\
\hline II & 2 & 57,1 & 4 & 28,6 & 0 \\
\hline III & 3 & 28,6 & 0 & 0 & 1 \\
\hline IV & 4 & 14,3 & 0 & 0 & \\
\hline
\end{tabular}

Sử dụng so sánh ghép cặp đánh giá sự tương quan mức độ khó thở của bệnh nhân trước và sau mổ thây sự khác biệt có ý nghĩa thống kê $(p=0,001)$. Tỷ lệ bệnh nhân có NYHA III-IV trước mổ chiếm $42,9 \%$ giảm xuống còn $0 \%$ sau mổ, tỷ lệ bệnh nhân không khó thở hoặc khó thở nhẹ sau mổ tăng lên 100\%. 
Bảng 5. Các chỉ số siêu âm tim và áp lực tĩnh mạch trung tâm trước và sau mố

\begin{tabular}{|c|c|c|c|}
\hline $\begin{array}{c}\text { Chỉ số nghiên } \\
\text { cứu }\end{array}$ & Trước mổ & Sau mổ & $\mathbf{p}$ \\
\hline EF & $62,3 \pm 6,8$ & $67,7 \pm 7,0$ & 0,032 \\
\hline $\begin{array}{c}\text { Dường kính thất } \\
\text { phải }\end{array}$ & $19,1 \pm 2,4$ & $20,2 \pm 6,0$ & 0,203 \\
\hline $\begin{array}{c}\text { Ap lực động } \\
\text { mạch phổi } \\
\text { (mmHg) }\end{array}$ & $34,8 \pm 10,6$ & $26,3 \pm 6,4$ & 0,001 \\
\hline $\begin{array}{c}\text { Ap lực tĩnh mạch } \\
\text { trung tâm CVPP } \\
\text { (cmH } 20)\end{array}$ & $19,2 \pm 4,1$ & $14,4 \pm 2,4$ & 0,000 \\
\hline
\end{tabular}

Kết quả siêu âm tim sau mố cho thây phân suất tống máu thất trái tăng có ý nghĩa thống kê từ $62,3 \pm 6,8 \%$ lên $67,7 \pm 7,0 \%(p=0,032)$ và áp lực động mạch phổi giảm có ý nghĩa thống kê từ $34,8 \pm 10,6 \mathrm{mmHg} x$ xuống $26,3 \pm 6,4 \mathrm{mmHg}$. Nhưng đường kính thất phải lại thay đổi không có ý nghĩa thống kê $(p=0,203)$. CVP trước mổ và sau mổ khác biệt có ý nghĩa thống kê $(p=0,000)$, giảm từ $19,2 \pm 4,1 \mathrm{cmH}_{2} 0$ xuống $14,4 \pm 2,4 \mathrm{cmH}_{2} 0$.

\section{BÀN LUẬN}

Có 14 bệnh nhân đủ tiêu chuẩn nghiên cứu. Lý do vào viện chủ yếu là khó thở $(100 \%)$ và đau ngực $(64,3 \%)$. Tỷ lệ này cao hơn so với nghiên cứu của Murat Bicer trên 47 bệnh nhân là $72,3 \%$ khó thở và $21,3 \%$ đau ngực ${ }^{1}$. Trên lâm sàng, triệu chứng nổi bật là triệu chứng suy tim phải, gồm: Gan to $(64,3 \%)$, phù chi dưới $(35,7 \%)$, tĩnh mạch cổ nổi $(28,6 \%)$, và cổ chướng $(28,6 \%)$ (Bảng 1). Trong đó, tỷ lệ gan to và cổ chướng cao hơn so với nghiên cứu của Murat Bicer $(23,4 \%$ và $19,1 \%)$, tỷ lệ phù chi dưới và tĩnh mạch cổ nổi thấp hơn (42,5\% và $34 \%)^{1}$.

Trên siêu âm tim, các hình ảnh hay gặp là dày màng tim $(100 \%)$ và vôi hóa màng tim $(78,6 \%)$. Trên Xquang ngực, các hình ảnh hay gặp là bóng tim to $(71,4 \%)$ và vôi hóa màng tim $(35,7 \%)$ (Bảng 2). Tỷ lệ bóng tim to trên Xquang cao hơn so với nghiên cứu của Anurag Mehta $(37 \%)^{3}$. Điều này là do trong nghiên cứu của chúng tôi, viêm màng ngoài tim co thắt thường đi kèm với tràn dịch màng tim (64,3\%) (Bảng 2), làm bóng tim to lên thay vì bình thường hoặc nhỏ lại như viêm màng ngoài tim co thắt thông thường ${ }^{3,6}$.

Về điêu trị, bệnh viện Việt Đức đã có nhiều kinh nghiệm trong phấu thuật viêm màng ngoài tim co thắt. Chúng tôi có sự chuẩn bị bệnh nhân kĩ càng trước mổ như: Đặt đường truyền cả chi trên và chi dưới, chuẩn bị sẵn dụng cụ để chạy tuần hoàn ngoài cơ thể và kim chỉ mạch máu, vật liệu cầm máu (bông surgicel, keo sinh học), máu truyền. Trong mổ, chúng tôi sử dụng đường mổ rộng rãi là đường giữa xương ức: Tất cả bệnh nhân trong nghiên cứu của chúng tôi đều sử dụng đường mổ này. Việc bóc màng tim được tiến hành tỉ mỉ và cẩn thân, đặc biệt ở vi trí các động mạch vành, bóc từ chố dễ đến chố khó, hạn chế đè ép tim lúc bóc mặt sau tim, ưu tiên bóc tối đa lỗ đổ vào của tĩnh mạch chủ trên và chủ dưới, giải phóng tối đa thất phải, tuy nhiên cũng không cố lấy hết mảng vôi hóa vì nguy cơ gây rách cơ tim, thủng buồng tim. Trong trường hợp rách cơ tim, chúng tôi sử dụng chỉ mạch máu có miếng đềm để khâu. Miếng đệm có thể là vật liệu tổng hợp hoặc làm từ màng ngoài tim của chính bệnh nhân. Thời gian phẫu thuật trung bình là $175 \pm 31,3$ phút. Thời gian này dài hơn so với nghiên cứu của $B$. Cinar (140 \pm 70 phút) và nghiên cứu của Murat Bicer (156,4 445,7 phút), nhưng thấp hơn so với nghiên cứu của Yoshiyuki Tokuda trên 346 bênh nhân là $265 \pm 105$ phút $t^{1,2,5}$.

Biến chứng phấu thuât trong nghiên cứu của chúng tôi gồm có: Suy thận $(7,1 \%)$ và viêm phổi $(7,1 \%)$ (Bảng 3). Tỷ lệ suy thận thấp hơn so với nghiên cứu của Yoshiyuki Tokuda $(9,8 \%)$. Tỷ lệ viêm phổi cao hơn so với nghiên cứu của Yoshiyuki Tokuda $(4,6 \%)$. Ngoài ra tác giả Yoshiyuki Tokuda còn nhắc đến các biến chứng khác không xảy ra trong nghiên cứu của chúng tôi như: Suy đa tạng, đột qụy, ngừng tuần hoàn, rung nhĩ... $50 \%$ bệnh nhân phải dùng thuốc trợ tim sau mổ do hội chứng cung lượng tim thấp, cao hơn so với nghiên cứu của Murat Bicer $(23,4 \%)^{1}$. Bênh nhân sau mổ có áp lực tĩnh mạch trung tâm và áp lực động mạch phổi giảm, cải thiện được tình trạng khó thở ít nhất một bậc theo phân độ NYHA, sự thay đổi có ý nghĩa thống kê (Bảng 4,5). Không có bênh nhân tử vong sớm sau mố. So sánh với một số nghiên cứu khác trên thế giới, tỷ lệ tử vong sớm sau mổ là: Murat Bicer $(2,1 \%)$, B. Cinar $(8,6 \%)$, Yoshiyuki Tokuda $(10 \%)$ và Ana M. Peset $(16 \%)$. Như vậy kết quả sớm của phẫu thuật là tương đối tốt.

Nghiên cứu của chúng tôi thấy nguyên nhân bênh lao chiếm tỷ lệ lớn (42,9\%). Kết quả này cũng tương tự như nghiên cứu của Murat Bicer và cộng sự nẳm $2015(46,8 \%)^{1}$. Ngoài ra Murat Bicer và cộng sự cũng chỉ ra các nguyên nhân khác như vô căn, ung thư, sau xạ trị, sau phẫu thuật tim nhưng không thấy ở nghiên cứu của chúng tôi. Điều này có thể lý giải do số lượng bênh nhân trong nghiên cứu của chúng tôi còn hạn chế, ngoài ra các bệnh nhân chỉ được làm giải phẫu bệnh với mục đích là tìm nguyên nhân do lao để điều trị thuốc lao sau phẫu thuật, nên 
chưa tầm soát được các nguyên nhân khác.

\section{KẾT LUẦN}

Viêm màng ngoài tim co thắt có đặc điểm lâm sàng nổi bật là triệu chứng của suy tim phải. Siêu âm tim và cắt lớp vi tính đóng một vai trò quan trọng trong việc khẳng định chẩn đoán. Phẫu thuật cắt màng tim rộng rãi đem lại kết quả sớm sau mổ tương đối tốt.

\section{TÀI LIỆU THAM KHẢO}

1. Murat Bicer, Bulent Ozdemir, Iris Kan, et al. Long-term outcomes of pericardiectomy for constrictive pericarditis. Journal of cardiothorac surgery.2015;10:177.

2. B. Cinar, Y. Enc, O. Gokse, et al. Chronic constrictive tuberculous pericarditis: Risk factors and outcome of pericardiectomy. Int J Tuberc Lung Dis.2006;10(6):701-6.

3. Anurag Mehta, Mahaveer Mehta, Abnash $C$. Jan, et al. Constrictive Pericarditis. Clin Cardiol.1999;22(5):334-344.

4. Ana M. Peset, Vicens Marti, Montserrat Cardona, et al. Outcome of Pericardiectomy for Chronic Constrictive Pericarditis. Rev Esp Cardiol. 2007;60(10):1097-101.

5. Yoshiyuki Tokuda, Hiroaki Miyata, Noboru Motomura, et al. Outcome of Pericardiectomy for Constrictive Pericarditis in Japan: A Nationwide Outcome Study. Ann Thorac Surg.2013;96(2):571-6.

6. Adler $Y$, Charron $P$, Imazio $M$, et al. ESC Guidelines for the Diagnosis and Management of Pericardial Diseases. Task Force for the Diagnosis and Management of Pericardial Diseases of the European Society of Cardiology. G Ital Cardiol (Rome).2015;16(12):702-38.

\section{ĐĂC ĐIỂM MÔ BỆNH HỌC CỦA BÊ̂NH GAN DO RƯợU}

\section{TÓM TẮT}

Mục tiêu: Xác định đặc điểm mô bệnh học của bệnh gan do rượu. Đối tượng và phương phá: Gồm 60 bệnh nhân mắc bệnh gan do rượu điều trị nội trú tại Bệnh viện Quân y 103, từ tháng 01/2015 đến 7/2017. Các chỉ số nghiên cứu là hình thái gan nhiễm mõ và giai đoan xơ hóa gan theo Metavir, gồm: F0 (không xơ hóa), F1 (xơ hóa nhẹ); F2 (xơ hóa vửa), F3 (xơ hóa nặng) và $F 4$ ( $x o ̛$ gan thực sự). Kết quả và kết luận: $100 \%$ bệnh nhân mắc bệnh gan do rượu có gan nhiễm mỡ. Phần lớn là nhiễm mỡ giot nhỏ $(71,7 \%)$, mức độ nhẹ $(93,3 \%)$ và ở vùng 1 (90,0\%). Một số tổn thương khác hay gặp là thoái hóa hạt $(100 \%)$, thể Mallory $(65,0 \%)$, nhiếm sắc tố $(28,3 \%)$ và biến đổi ưa toan tế bào gan (15,0\%). Đánh giá giai đoạn xơ hóa gan theo phân loại Metavir thấy không xơ hóa gan (F0) là $6,7 \%$; xơ hóa nhe ( $F 1$ ) là $50,0 \%$; xơ hóa gan vừa (F2) là 11,7\%; xơ hóa gan nặng (F3) là $15,0 \%$ và xơ gan thực sự (F4) là 16,7\%.

Tư khóa: Bệnh gan do rượu, mô bệnh học, xơ hóa gan, xơ gan.

\section{SUMMARY \\ HISTOPATHOLOGICAL CHARACTERISTICS OF ALCOHOLIC LIVER DISEASE}

Objective: To determine the histopathological characteristics of alcoholic liver disease. Subjects and methods: 60 patients with alcoholic liver disease were inpatient at 103 Military Hospital, from January 2015 to July 2017. The research indicators are fatty liver morphology and liver fibrosis stage according to

*Học viện Quân y

Chịu trách nhiệm chính: Seng Someth

Email: nguyenvankhoi1980@gmail.com

Ngày nhận bài: 30/6/2021

Ngày phản biên khoa học: 31/7/2021

Ngày duyệt bài: 23/8/2021

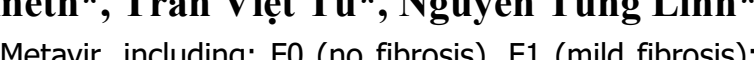
F2 (moderate fibrosis), F3 (severe fibrosis) and F4 (cirrhosis). Results and conclusion: $100 \%$ of patients with alcoholic liver disease had fatty liver. The majority were fatty dropsy (71.7\%), mild (93.3\%), and in zone 1 (90.0\%). Some other common lesions are foamy degeneration $(100 \%)$, Mallory body $(65.0 \%)$, chromophore $(28.3 \%)$ and hepatocellular eosinophilia (15.0\%). Evaluation of liver fibrosis stage according to Metavir classification showed no liver fibrosis (F0) was $6.7 \%$; mild fibrosis (F1) was $50.0 \%$; moderate liver fibrosis (F2) was $11.7 \%$; Severe cirrhosis (F3) was $15.0 \%$ and cirrhosis (F4) was $16.7 \%$.

Keywords: Alcoholic liver disease, histopathology, liver fibrosis, liver cirrhosis.

\section{I. ĐẶT VẤN ĐỀ}

Mô bệnh học là tiêu chuẩn vàng để đánh giá mức độ viêm, hoại tử nhằm tiên lượng, theo dõi điều trị bệnh gan do rượu (BGDR). Khoảng $90 \%$ số người nghiện rượu có gan thoái hóa mõ (GTHM), lúc đầu là vùng 3 , nếu tiếp tục uống rượu tình trạng thoái hóa mõ sẽ nặng, lan tỏa toà̀n gan. Nhiễm mõ gan dưới ba dạng: giọt nhỏ, giọt lớn và hỗn hợp. Trong BGDR, nhiềm mõ gan giọt lớn hay gặp hơn [1], [2], [3].

Thoái hóa hạt do rượu thường gặp ở GTHM do rượu: tế bào gan phồng lên với các hạt trong bào tương phân tán thành các sợi mảnh. Nhân tế bào nhỏ và bắt màu đậm (tăng sắc). Rượu làm tổn thương màng ty thể và làm ty thể phồng to, tạo nên các thể hình cầu trong bào tương. Bên trong những tế bào gan thường thấy các thể Mallory do sự ngưng tập các protein nội bào [4], [5], [6], [7]. Đặc điểm đại thể gợi ý xơ gan do rượu bao gồm khối lượng thùy đuôi lớn hơn, 
nhiều nốt gan sau bên phải, và kích thước ổ tái tạo tế bào gan nhỏ hơn so với xơ gan do virus viêm gan. Sự tăng sinh sợi xơ non và lắng đọng collagen vùng 3 là tổn thương đầu tiên của quá trình xơ gan do rượu. Xơ gan do rượu là xơ gan nốt nhỏ, cấu trúc các vùng không bình thường và tĩnh mạch vùng 3 rất khó tìm thấy. ứ đọng sắt trong tế bào gan (khoảng $1 / 3$ các trường hợp) là do tăng hấp thu sắt ở ruột và lượng sắt trong các đồ uổng có cồn [5], [8].

Nghiên cứu được tiến hành nhằm mục tiêu: Xác định đặc điểm mô bệnh học của bệnh gan do rươu.

\section{II. ĐỐI TƯợNG VÀ PHƯƠNG PHÁP NGHIÊN CỨU}

2.1. Đối tượng nghiên cứu. Gồm 60 bệnh nhân (BN) được chẩn đoán BGDR điều trị nội trú tại Khoa Nội tiêu hóa Bệnh viện Quân y 103, từ tháng 01/2015 đến 7/2017.

\subsection{Phương pháp nghiên cứu}

*Thiết kế nghiên cứu: Nghiên cứu mô tả cắt ngang, có phân tích.

\section{*Các chỉ số nghiên cứu:}

- Sinh thiết gan bằng súng sinh thiết cắt tự động Pajunk của CHLB Đức và kim Deltacut dùng một lần.

- Tiêu chuẩn mẫu mô gan đạt yêu cầu: không chảy máu, không hoại tử, có ít nhất 6 khoảng cửa và chiêu dài mẫu mô gan $>1,5 \mathrm{~cm}$.

- Đánh giá hình thái gan nhiếm mõ chia làm các nhóm sau:

+ Giọt lớn: lipid chiếm toàn tế bào chất của tế bào gan, đầy lệch hạt nhân ra ngoai vi.

+ Giọt nhỏ: lipid phân phối đều trong tế bào chất của tế bào gan, không làm thay đổi vị trí hạt nhân.

+ Hỗn hợp: vừa nhiễm mõ giọt lớn, vừa nhiễm mõ giọt nhỏ.

- Đánh giá mức độ gan thoái hóa mõ chia làm các nhóm sau:

+ Nhẹ: khi số lượng tế bào gan thoái hóa mõ từ $5-33 \%$.

+ Trung bình: khi số lượng tế bào gan thoái hóa mõ từ $34-66 \%$.

+ Nặng: khi số lượng tế bào gan thoái hóa mõ $>66 \%$.

- Đánh giá vùng gan thoái hóa mõ: vùng 1 (quanh tĩnh mạch trung tâm tiểu thùy), vùng 2 (trung gian) và vùng 3 (quanh khoảng cửa).

- Đánh giá giai đoạn xơ hóa gan theo phân loại Metavir: F0 (không xơ hóa gan", F1 (xơ hóa nhẹ: xơ hóa quanh xoang, có hoặc không xơ hóa quanh tế bào); $F 2$ (xơ hóa vừa: xơ hóa khoảng cửa, rất ít các dải xơ), F3 (xơ hóa nặng: xơ hóa khoảng cửa và quanh khoảng cửa, nhiêu dải $x o ̛$ ) và $F 4$ (xơ gan). Trong đó, có xơ hóa gan là $\geq F 1$; xơ hóa gan đáng kể là $\geq F 2 ;$ xơ hóa gan nặng là $\geq F 3$ và $x \sigma$ gan là $=F 4$.

- Các số liệu nghiên cứu được xứ lý theo phương pháp thống kê y sinh học theo chương trình SPSS 22.0.

\section{KẾT QUẢ NGHIÊN CỨU}

Bảng 1. Đặc điểm tổn thương mô bệnh học ở bệnh nhân mắc bệnh gan do rượu.

\begin{tabular}{|c|c|c|c|}
\hline \multicolumn{2}{|c|}{$\begin{array}{l}\text { Đăc điểm gan } \\
\text { thoái hóa mơ }\end{array}$} & \multirow{2}{*}{\begin{tabular}{|c|}
$\begin{array}{c}\text { Số BN } \\
(\mathbf{n}=\mathbf{6 0})\end{array}$ \\
60
\end{tabular}} & \multirow{2}{*}{$\begin{array}{c}\begin{array}{c}\text { Tỷ lệ } \\
(\%)\end{array} \\
100,0\end{array}$} \\
\hline \multicolumn{2}{|c|}{ Thoái hóa mõ tế bào gan } & & \\
\hline \multirow{3}{*}{$\begin{array}{c}\text { Hình thái } \\
\text { gan } \\
\text { thoái hóa } \\
\text { mõ }\end{array}$} & Giọt lớn & 8 & 13,3 \\
\hline & Giọt nhỏ & 43 & 71,7 \\
\hline & Hỗn hợp & 9 & 15,0 \\
\hline \multirow{3}{*}{$\begin{array}{c}\text { Mức độ gan } \\
\text { thoái hóa } \\
\text { mõ }\end{array}$} & Nhẹ $(<33 \%)$ & 56 & 93,3 \\
\hline & Vừa (34- 66\%) & 2 & 3,3 \\
\hline & Nặng (>67\%) & 2 & 3,3 \\
\hline \multirow{3}{*}{$\begin{array}{c}\text { Vùng gan } \\
\text { thoái hóa } \\
\text { mõ }\end{array}$} & Vùng 1 & 54 & 90,0 \\
\hline & Vùng $1+2$ & 4 & 6,7 \\
\hline & Vùng $1+2+3$ & 2 & 3,3 \\
\hline \multirow{4}{*}{$\begin{array}{c}\text { Một số tổn } \\
\text { thương } \\
\text { khác }\end{array}$} & Thoái hóa dạng bọt & 60 & 100,0 \\
\hline & Thể Mallory & 39 & 65,0 \\
\hline & Nhiêm sắc tố & 17 & 28,3 \\
\hline & $\begin{array}{c}\text { Biến đối ưa toan } \\
\text { tế bào gan }\end{array}$ & 9 & 15,0 \\
\hline
\end{tabular}

Qua bảng 1 thấy $100 \%$ BN mắc BGDR có gan nhiễm mõ.

- Hình thái GTHM: giọt nhỏ chiếm tỷ lệ cao nhất $(71,7 \%)$, tiếp đến là GTHM hỗn hợp $(15,0 \%)$ và GTHM giọt lớn (13,3\%).

- Mức độ GTHM: Đa số BN có GTHM mức độ nhe $(93,3 \%)$, GNM mức độ vừa và nặng chiếm tỷ lệ thấp (3,3\% và $3,3 \%)$.

- Vùng GTHM: hầu hết là vùng $1(90,0 \%)$.

- Một số tổn thương khác của BGDR: thoái hóa hạt $(100 \%)$, thể Mallory $(65,0 \%)$, nhiễm sắc tố $(28,3 \%)$ và biến đổi ưa toan tế bào gan $(15,0 \%)$

Bảng 2. Giai đoan xơ hóa gan trên mô bênh hoc

\begin{tabular}{|c|c|c|c|}
\hline $\begin{array}{c}\text { Giai đoạn Xơ hóa } \\
\text { gan trên mô bệnh } \\
\text { học }\end{array}$ & $\begin{array}{c}\text { Số BN } \\
(\mathbf{n = 6 0 )}\end{array}$ & $\begin{array}{c}\text { Tỷ lệ } \\
\mathbf{( \% )}\end{array}$ & $\begin{array}{c}\text { Tần suất } \\
\text { cộng dồn } \\
(\%)\end{array}$ \\
\hline F4 & 10 & 16,7 & 16,7 \\
\hline F3 & 9 & 15,0 & 31,7 \\
\hline F2 & 7 & 11,7 & 43,3 \\
\hline F0 & 30 & 50,0 & 93,3 \\
\hline 4 & 6,7 & 100,0 \\
\hline
\end{tabular}

Đánh giá giai đoạn xơ hóa gan theo phân loại Metavir thây không xơ hóa gan (F0) là 6,7\%; có xơ hóa gan ( $\geq F 1$ ) là $93,3 \%$; xơ hóa gan đáng kể ( $\geq F 2$ ) là $43,3 \%$; $x$ ơ hóa gan nặng $(\geq F 3)$ là 
$31,7 \%$ và xơ gan thực sự (F4) là 16,7\%.

\section{BÀN LUÂिN}

4.1. Đặc điểm gan thoái hóa mõ̃ của bệnh gan do rượu. Đặc điểm mô bệnh học phổ biến nhất của BGDR là tế bào gan thoái hóa mõ, do sự tích tụ các giọt lipid, thường là nhiễm mõ giọt lớn hoặc hỗn hợp. Sự thoái hóa mõ thường bắt đầu từ vùng 3 là vùng được cung cấp máu nuôi dưỡng ít nhất, sau đó lan dần đến vùng quanh khoảng cửa, khi thoái hóa mõ nặng sẽ lan ra toàn bộ tiểu thùy gan [1], [2], [3].

Kết quả nghiên cứu cho thấy $100 \% \mathrm{BN}$ mắc BGDR có tế bào gan thoái hóa mõ. Chủ yếu là GNM giọt nhỏ $(71,7 \%)$, mức độ nhe $(93,3 \%)$ và ở vùng $1(90,0 \%)$, (bảng 1). Nhận xét của chúng tôi cũng tương tự kết quả nghiên cứu của Lê Thị Thu Hiên (2017) ở BN mắc BGDR: 92,8\% các trường hợp có GTHM; chủ yếu là GTHM hỗn hợp (GTHM giọt nhỏ, vừa và lớn): $72,7 \%$; nhiễm mõ mức độ vừa là $39 \%$ và hầu hết GTHM vùng trung tâm (vùng 1): 94,8\% [1]. Lê Quốc Tuấn (2019) cũng thấy nhiễm mõ hỗn hợp chiếm tỷ lệ cao nhất (69,5\%). Mức độ nhiễm mỡ từ 34- 66\% chiếm tỳ lệ $42,1 \%$. Thoái hóa mõ gan vùng 1 chiếm tỳ lệ $95,8 \%$, vùng 2 là $71,6 \%$, vùng 3 là $69,5 \%$ [2].

Nghiên cứu của Vũ Thị Thu Trang (2019) ở bệnh nhân GTHM cho thấy phần lớn các trường hợp $(63,7 \%)$ là thoái hóa mõ hạt to và hỗn hợp cả hạt to và hạt nhỏ nhưng thoái hóa mõ hạt to vẫn là chủ đạo $(33,4 \%)$, chỉ có $2,9 \%$ là thoái hóa mõ hạt nhỏ là chính. Chủ yếu là thoái hóa mõ độ $1(41,2 \%)$ và độ $2(44,1 \%)$, thoái hóa mõ nặng độ 3 chỉ chiếm 14,7\%. Ở giai đoạn GTHM đơn thuần, $100 \%$ thoái hóa mõ mức độ nhẹ, ở giai đoạn viêm gan nhiễm mõ có các mức độ thoái hóa mõ khác nhau trong đó chủ yếu là mức độ trung bình (50\%). Thoái hóa mõ lan tỏa toàn bộ gan chiếm $74,5 \%$, thoái hóa mõ vùng 3 chiếm 22,6\%. Không thấy có sự khác biệt về kiểu thoái hóa mõ, mức độ nhiếm mõ và vị trí thoái hóa mõ giữa hai nhóm GTHM do rượu và GTHM không do rượu [3].

\section{2. Đăc điểm một số tổn thương khác} trên mô bệnh học của bệnh gan do rượu. Thoái hóa hạt do rượu thường gặp trong BGDR, tế bào gan phồng lên với các hạt trong bào tương, các hạt này thường phân tán thành các sợi mảnh. Nhân tế bào nhỏ và bắt màu đậm (tăng sắc). Bọt hình thành do giữ nước và mất khả năng tiết protein của các vi ống từ tế bào gan. Rượu làm tổn thương màng ty thể và làm ty thể phồng to lên. Phồng tế bào gan là tổn thương tế bào gan cơ bản trong bệnh GTHM, đây là một dạng chết tế bào theo chương trình (apoptosis). Phồng tế bào gan có thể được sửa chữa phục hồi nhưng phần lớn sẽ tiến tới ly giải tế bào. Bên trong những tế bào gan thường thấy các thể Mallory do sự ngưng tập các protein nội bào [1], [2], [3].

Qua nghiên cứu thấy ở BN mắc BGDR thấy $100 \%$ số BN có thoái hóa dạng bọt, thể Mallory là $65,0 \%$, nhiễm sắc tố là $28,3 \%$ và biến đổi ưa toan tế bào gan $(15,0 \%)$ (bảng 1$)$. Điều này cũng tương tự nhận xét của Lê Thị Thu Hiền (2017): hay gặp là thoái hóa hạt do rượu $(84,3 \%)$, ty thể khổng lồ $(63,4 \%)$ và thể Mallory $(60,2 \%)[1]$; của Lê Quốc Tuấn (2019): thoái hóa hạt do rượu $(84,2 \%)$, nhiễm sắc tố $(56,8 \%)$, thể Mallory $(64,2 \%)$, ty thể khổng lồ $(62,1 \%)$ và biến đổi ái toan $(63,2 \%)$ [2].

Nghiên cứu của Vũ Thị Thu Trang (2019) cho thây có $92,2 \%$ bệnh nhân GNM có phồng tế bào gan, trong đó có $49 \%$ các trường hợp có phồng tế bào gan mức độ nhiều. Nhóm viêm GTHM và xơ gan $100 \%$ có phồng tế bào gan trong khi nhóm GTHM đơn thuần chỉ có $33,3 \%$ có phồng tế bào gan. Không có sự khác biệt về tỷ lệ phồng tế bào gan giữa nhóm GTHM do rượu và GTHM không do rượu. Có 35,3\% bệnh nhẩn GTHM có thể Mallory, nhưng chỉ có $16,3 \%$ bệnh nhân GNM không do rượu có thể Mallory, ngược lại, có tới $55,9 \%$ bệnh nhân GTHM do rượu có tổn thương này. Có $16,7 \%$ bệnh nhân GTHM có ty thể khổng lî̀, chủ yếu là các bênh nhân GTHM do rượu $(32,4 \%)$ và chỉ có $4,7 \%$ ở nhóm GTHM không do rượu, sự khác biệt có ý nghĩa thống kê $(p<0,05-0,001)$ [3].

4.3. Đắc điểm xơ hóa gan trên mô bệnh học. Xơ hoá gan là do chuyển dạng của tế bào sao thành tế bào xơ non. Mức độ xơ hóa phụ thuộc vào tân suất tái phát, thời gian bị bệnh và mức đô bênh. Sự phát triển từ xơ hóa gan và cuối cùng dẫn đến xớ gan là đặc điểm phổ biến tất cả BN bệnh gan mạn tính. Theo phân loại Metavir: xơ hóa gan nhe là xơ hóa quanh xoang (F1), xơ hóa gan vừa là xơ hóa khoảng cửa (F2), xơ hóa nặng là nhiều dải xơ khoảng cửa và quanh khoảng cửa $(\mathrm{F} 3)$ và xơ gan (F4) [1], [2], [3].

Chúng tôi đánh giá giai đoạn xơ hóa gan theo phân loại Metavir thấy không xơ hóa gan (F0) là $6,7 \%$; xơ hóa gan nhẹ ( $F 1)$ là $50,0 \%$; xơ hóa gan vừa (F2) là $11,7 \%$; xơ hóa gan nặng (F3) là $15,0 \%$ và xơ gan thực sự (F4) là $16,7 \%$. Tỷ lẹ có xơ hóa gan $(\geq F 1)$ là $93,3 \%$, xơ hóa gan đáng kể ( $\geq F 2$ ) là $43,3 \%$ và xơ hóa gan nặng $(\geq F 3$ ) là $31,7 \%$. Tần suất xơ hóa gan ở BN mắc $B G D R$ 
trong nghiên cứu của chúng tôi cũng tương tự kết quả nghiên cứu của Lê Thị Thu Hiền (2017): xơ hóa gan F2 $(24,1 \%)$ và $F 3(25,3 \%)$ chiếm tỷ lệ cao nhất, xơ hóa gan $\mathrm{F} 4$ chiếm tỷ lệ thấp nhất (14,5\%) [1]; của Lê Quốc Tuấn (2019): BN giai đoạn viêm gan do rượu chiếm tỷ lệ là $87,4 \%$. Giai đoạn xơ hóa theo Metavir: giai đoạn F2 và $\mathrm{F} 3$ chiếm tỷ lệ lần lượt là $26,3 \%$ và $25,3 \%$; xơ hóa gan thực sự (F4) là 12,6\%. Mức độ xơ hóa gan đáng kể ( $\geq F 2$ ) chiếm tỷ lệ là $62,1 \%$ [2].

Nghiên cứu của Vũ Thị Thu Trang (2019) ở bệnh nhân GTHM cho thây loại xơ hóa hay gặp là xơ hóa quanh tế bào $(95,1 \%)$, xơ hóa quanh mao mạch nan hoa $(92,1 \%)$, xơ hóa khoảng cửa và quanh khoảng cửa $(80,4 \%)$. Tỷ lệ vách xơ là $22,5 \%$, cầu xơ là $14,7 \%$ và xơ gan là $4,9 \%$. Không có sự khác biệt về tỷ lệ xơ hóa quanh mao mạch nan hoa và quanh tế bào giữa hai nhóm GTHM do rượu và không do rượu. Tuy nhiên, tỷ lệ xơ hóa khoảng cửa và quanh khoảng cửa ở nhóm GTHM do rượu $(94,1 \%)$ cao hơn nhóm GTHM không do rượu $(62,8 \%)$, sự khác biệt có ý nghĩa thống kê với $p<0,001$ [3].

Như vậy, xơ hóa gan do rượu, xuất hiện đầu tiên vùng 3 và là minh chứng rằng $\mathrm{BN}$ uống nhiều rượu. Những $B N$ có xơ hóa gan đáng kể ( $\geq$ F2) cần được điều trị ngay, để tránh tiến triển thành xơ hóa gan nặng. Đối với $B N$ có xơ hóa gan nặng ( $\geq F 3)$, cần theo dõi để phát hiện biến chứng ung thư gan, giãn võ̃ tĩnh mạch thực quản.

\section{KẾT LUẬN}

- 100\% bệnh nhân mắc bênh gan do rượu có gan thoái hóa mỡ. Phần lớn là thoái hóa mở giọt nhỏ $(71,7 \%)$, mức độ nhe $(93,3 \%)$ và ở vùng 1 (90,0\%). Một số tổn thương khác hay gặp là thoái hóa hạt $(100 \%)$, thể Mallory $(65,0 \%)$, nhiễm sắc tố $(28,3 \%)$ và biến đổi ưa toan tế bào gan $(15,0 \%)$.

- Đánh giá giai đoạn xơ hóa gan theo phân loại Metavir thấy không xơ hóa gan (F0) là $6,7 \%$; xơ hóa nhe (F1) là $50,0 \%$; xơ hóa gan vừa (F2) là $11,7 \%$; xơ hóa gan nặng (F3) là $15,0 \%$ và xơ gan thực sự (F4) là $16,7 \%$.

\section{TÀI LIẸU THAM KHẢO}

1. Lê Thi Thu Hiền (2017), Nghiên cứu một số đặc điểm lầm sàng, cận lâm sàng và chỉ số chống oxy hóa trong máu ở bệnh nhân mắc bệnh gan do rượu, Luận án Tiễn sĩ y học, Đại học YD Thái Nguyên.

2. Lề Quốc Tuấn (2019), Nghiên cứu đă̆c điểm lâm sàng, cận lâm sàng và nồng đố một số cytokin huyết tương trên bệnh nhân mắc bểnh gan mạn do rượu, Luận án Tiên sĩ y học, Đại học YD Thái Nguyên.

3. Vũ Thị Thu Trang (2019), Nghiên cứu đăcc điểm lâm sàng, một số xét nghiệm, siêu âm và mồ bệnh hoc bệnh gan nhiếm mỡ, Luận án Tiến sĩ y học, Viện NCKHYDLS 108

4. Altamirano J., Miquel R., Katoonizadeh A. et al. (2014), "A histologic scoring system for prognosis of patients with alcoholic hepatitis", Gastroenterology, 146: 1231-1239.

5. Celli R., Zhang X. (2014), "Pathology of Alcoholic Liver Disease", Journal of Clinical and Translational Hepatology, vol. 2, 103-109.

6. Dubois M., Sciarra A., Trépo E. Et al. (2020), "Histologic parameter score does not predict shortterm survival in severe alcoholic hepatitis", United European Gastroenterol J., 8(9):1003-1012.

7. Ntandja Wandji L. C., Gnemmi V. et al. (2020), "Combined alcoholic and non-alcoholic steatohepatitis", JHEP Rep., 2(3): 100- 101.

8. Sakhuja P. et al (2014), "Pathology of alcoholic liver disease, can it be differentiated from nonalcoholic steatohepatitis? World J Gastroenterol., 20 (44): 16474-16479.

\title{
ĐẶC ĐIỂM MộT Số CHỈ Số HUYẾT HỌC VÀ ĐÔNG MÁU Ở BÊ̂NH GAN DO RƯợU
}

\author{
Seng Someth*, Trần Việt Tú*, Nguyễn Tùng Linh*
}

\section{TÓM TẮT}

Muc tiêu: Xác định đặc điểm và mối liên quan một số chỉ số huyết học và đông máu với mô bệnh hợ ở bênh gan do rượu. Đối tượng và phướng pháp: Gồm 60 bệnh nhân mắc bệnh gan do rượu điều

\footnotetext{
*Hoc viên Quân y

Chịu trách nhiệm chính: Seng Someth Email: nguyenvankhoi1980@gmail.com Ngày nhận bài: $1 / 7 / 2021$

Ngày phản biên khoa học: 1/8/2021

Ngày duyệt bài: 25/8/2021
}

trị nội trú tại Bênh viện Quân y 103, từ tháng 01/2015 đến $7 / 2017$. Các chỉ số nghiên cứu là số lượng hồng cầu, hàm lượng hemoglobin, số lượng bạch câu, số lượng tiểu cầu, tỷ lệ Prothrombin, thời gian APTT, nồng độ Fibrinogen và chỉ số INR. Kết quả và kết luân: $45,0 \%$ số bệnh nhân mắc bênh gan do rươu giảm số lượng hồng câu <4,2 T/l; 16,7\% bệnh nhẩn giảm nồng độ hemoglobin $<120 \mathrm{~g} / \mathrm{l}$ và $35,0 \%$ số bệnh nhân giảm số lượng tiểu cầu $<140 \mathrm{G} / \mathrm{l}$. Nồng độ $\mathrm{Hb}$ và số lượng tiểu cầu tương quan nghịch với giai đoạn xơ hóa gan trên mô bênh hoc $(r=-0,25$ và $r=-0,28$; $\mathrm{p}<0,05)$. Có $6,7 \%$ bệnh nhân giảm tỷ lệ Prothrombin $<70 \%$; có 3,3\% bệnh nhân tăng chỉ số INR >1,3. Có $13,3 \%$ bệnh nhân giảm nồng độ Fibrinogen <2 $\mathrm{g} / \mathrm{l}$ và 
$1,7 \%$ bệnh nhân có thời gian APTT kéo dài > 40 giây. Tỷ lệ Prothrombin (\%) tương quan nghịch với giai đoan xơ hóa gan $(r=-0,42 ; p<0,001)$, chỉ số INR tưởng quan thuận với giai đoạn xơ hóa gan trên mô bênh hoc $(r=0,37 ; p<0,01)$.

Tư khóa: Bệnh gan do rượu, huyết học, đông máu

\section{SUMMARY}

CHARACTERISTICS OF SOME HEMATOLOGICAL AND COAGULATION INDICATORS IN ALCOHOLIC LIVER DISEASE

Objectives: To determine the characteristics and relationship of some hematological and coagulation indices with histopathology in alcoholic liver disease. Subjects and methods: 60 patients with alcoholic liver disease were inpatient at 103 Military Hospital, from January 2015 to July 2017. The research indicators are red blood cell count, hemoglobin content, white blood cell count, platelet count, Prothrombin (\%), activated partial thromboplastin time (APTT), fibrinogen concentration and International normalized ratio (INR). Results and conclusion: $45.0 \%$ of patients with alcoholic liver disease reduced red blood cell count $<4.2 \mathrm{~T} / \mathrm{l} ; 16.7 \%$ of patients decreased hemoglobin concentration $<120$ $\mathrm{g} / \mathrm{l}$ and $35.0 \%$ of patients decreased platelet count $<140 \mathrm{G} / \mathrm{l}$. Hb concentration and platelet count were inversely correlated with the stage of liver fibrosis on histopathology $(r=-0.25$ and $r=-0.28 ; p<0.05)$. There were $6.7 \%$ patients reduced Prothrombin rate $<70 \%$; $3.3 \%$ of patients increased INR $>1.3$. There were $13.3 \%$ patients decreased Fibrinogen concentration $<2 \mathrm{~g} / \mathrm{l}$ and $1.7 \%$ patients had APTT duration $>40$ seconds. Prothrombin (\%) is negatively correlated with liver fibrosis stage $(r=-0.42 ; p<0.001)$, INR is positively correlated with liver fibrosis stage on histopathology $(r=0.37 ; p<0.01)$.

Keywords: Alcoholic liver disease, hematology, blood coagulation

\section{I. ĐĂT VẤN ĐỀ}

Ở bệnh nhân (BN) mắc bệnh gan do rượu (BGDR) thường có thiếu máu nhưng chỉ thiếu máu mức độ nhẹ. Nguyên nhân thiếu máu là do chảy máu do vỡ tĩnh mạch thực quản, thiếu acid folic và vitamin B12 (do thiếu hụt dinh dưỡng người nghiện rượu, cường lách, ức chế trực tiếp của ethanol lên tủy xương) Chỉ số MCV thường lớn hơn $95 \mathrm{fl}$, có thể do tác động trực tiếp của rượu lên tủy xương, lên tế bào gốc tạo máu [1], [3], [7]. Huang và Cs (2017) thấy MCV có liên quan với mức độ bênh, MCV ở nhóm VGDR mức độ năng là $103,3 \pm 12,5 \mathrm{fl}$, xơ gan do rướu là $94,2 \pm 1,38 \mathrm{fl}, \mathrm{VGDR}$ mức độ nhe là $91,8 \pm 7,8 \mathrm{fl}$ và GNM do rượu là $91,05 \pm 6 \mathrm{fl}$ [7].

\section{KẾT QUẢ NGHIÊN CỨU}

Bảng 1. Một số chỉ số huyết hơc ở bênh nhân mắc bênh gan do rươuu.

\begin{tabular}{|c|c|c|c|}
\hline \multicolumn{2}{|c|}{ Chỉ số } & Số BN $(\mathbf{n}=\mathbf{6 0})$ & Tỷ lệ (\%) \\
\hline Số lượng & Giảm $<4,2 \mathrm{~T} / \mathrm{I}$ & 27 & 45,0 \\
\hline
\end{tabular}

Giảm số lượng và chất lượng tiểu cầu thường gặp những $B N$ có bệnh gan mạn tính và chiếm khoảng $76 \%$ số BN xơ gan. Mức độ giảm tiểu cầu là một yếu tố tiên lượng nặng, đặc biệt nếu giảm tiểu cầu $<50 \mathrm{G} / \mathrm{l}$. Cơ chế giảm tiểu cầu bệnh gan do giảm sản xuất tiểu cầu trong tủy xương, cường lách, giảm sản xuất thrombopoietin và yếu tố tự miễn. Trong BGDR, do rượu ức chế tủy xương giảm sản xuất tiểu cầu, rượu còn tác dụng trực tiếp trên lipid tiểu cầu, hệ thống truyền tin thứ hai. Gan đóng vai trò trung tâm trong việc duy trì quá trình đông cầm máu. Gan là nơi tổng hợp phần lớn các protein cần thiết cho việc điều hòa đông máu và tiêu sợi huyết. Do đó, suy giảm chức năng tế bào gan có thể gây rối loạn quá trình đông cầm máu, $\mathrm{BN}$ có nguy cơ bị chảy máu hoặc hình thành huyết khối [3], [6].

Nghiên cứu được tiến hành nhằm: Xác định đặc điểm và mối liên quan môt số chỉ số huyết học và đông máu với mô bệnh học ở bệnh gan do rươu.

\section{II. ĐỐI TƯỢNG VÀ PHƯƠNG PHÁP NGHIÊN CỨU}

2.1. Đối tượng nghiên cứu. Gồm $60 \mathrm{BN}$ được chẩn đoán BGDR điều trị nội trú tại Khoa Nội tiêu hóa Bệnh viện Quân y 103, từ tháng 01/2015 đến 7/2017.

\subsection{Phương pháp nghiên cứu}

* Thiết kế nghiên cứu:

Nghiên cứu mô tả cắt ngang, có phân tích.

* Các chỉ số nghiên cứu:

- Phân tích một số chỉ số huyết học (số lượng hồng cầu: SLHC, hàm lượng hemoglobin, số lượng bạch cầu: SLBC, số lượng tiểu cầu: SLTC...) bằng máy Cell-Dyn 1700 (Mỹ) tại Khoa Huyết học - Bệnh viện Quân y 103.

- Phẩn tích một số chỉ số đông máu (tỷ lệ Prothrombin, thời gian APTT, nồng độ Fibrinogen và chỉ số INR) bằng máy CA 150 (hãng SysmexNhật Bản) tại Khoa Huyết học - Bệnh viện Quân y 103.

- Đặc điểm mô bệnh học: Phân chia giai đoạn xơ hóa gan theo Metavir: không xơ hóa (F0), xơ hóa gan nhẹ (F1), xơ hóa gan đáng kể (F2), xơ hóa gan nặng (F3) và xơ gan thực sự (F4).

- Các số liệu nghiên cứu được xứ lý theo phương pháp thống kê y sinh học theo chương trình SPSS 22.0. 
VIETNAM MEDICAL JOURNAL N01 - SEPTEMBER - 2021

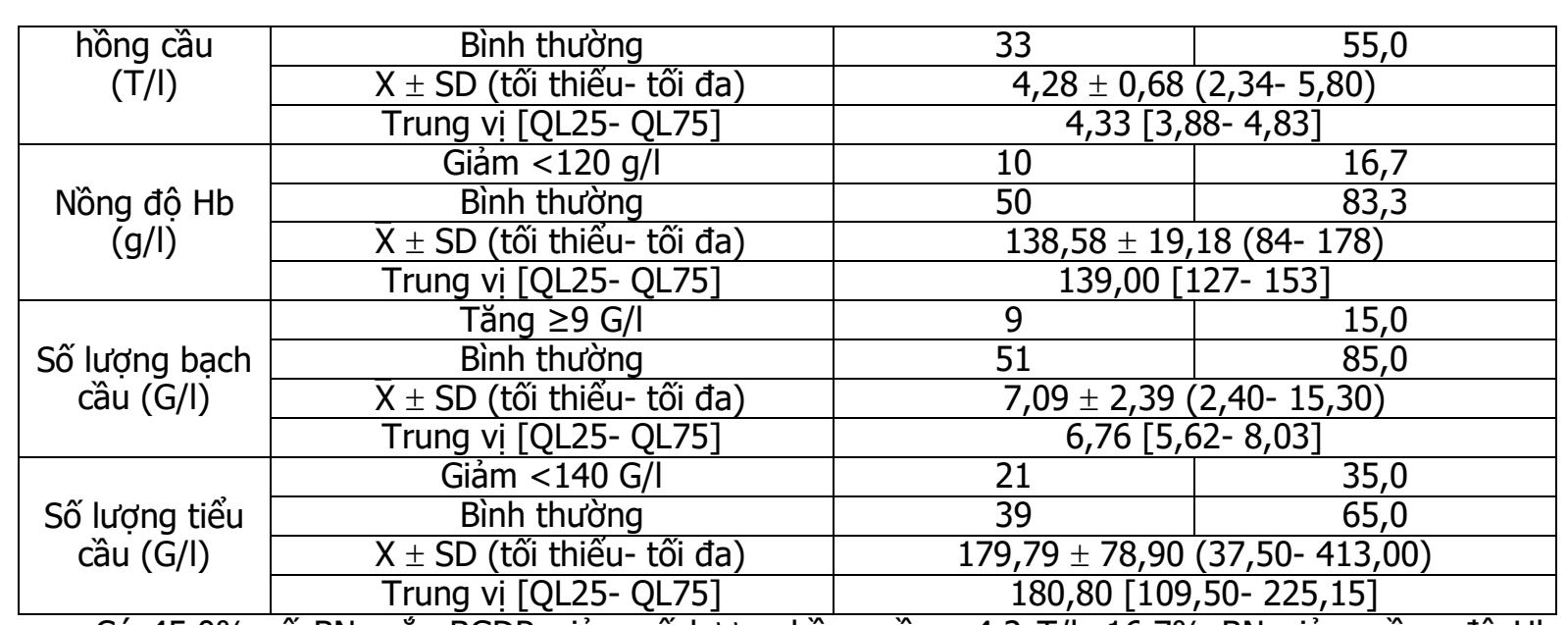

- Có 45,0\% số BN mắc BGDR giảm số lượng hồng cầu <4,2 T/l; $16,7 \% \mathrm{BN}$ giảm nồng độ $\mathrm{Hb}$ $<120 \mathrm{~g} / \mathrm{l}$ và $35,0 \%$ số $\mathrm{BN}$ giảm SLTC $<140 \mathrm{G} / \mathrm{l}$.

- SLBC trung bình là 7,09 $\pm 2,39(2,40-15,30) \mathrm{G} / \mathrm{l} ; 15,0 \%$ BN tăng SLBC $\geq 9 \mathrm{G} / \mathrm{l}$.

Bảng 2. Một số chỉ số đông máu ở bệnh nhân mắc bệnh gan do rượu.

\begin{tabular}{|c|c|c|c|}
\hline \multicolumn{2}{|c|}{ Chỉ số } & Số BN $(n=60)$ & Tỷ lê (\%) \\
\hline \multirow{4}{*}{$\begin{array}{c}\text { Tỷ lê } \\
\text { Prothrombin } \\
(\%)\end{array}$} & Giảm $<70 \%$ & 4 & 6,7 \\
\hline & Bình thường & 56 & 93,3 \\
\hline & $\mathrm{X} \pm \mathrm{SD}$ (tối thiếu- tối đa) & \multirow{2}{*}{\multicolumn{2}{|c|}{$\begin{array}{c}105,58 \pm 23,30(54,00-164,95) \\
109,00[89-123]\end{array}$}} \\
\hline & Trung vị [QL25- QL75] & & \\
\hline \multirow{4}{*}{ Chỉ số INR } & Tăng $>1,3$ & 2 & 3,3 \\
\hline & Bình thường & 58 & 96,7 \\
\hline & $\bar{X} \pm$ SD (tối thiểu- tối đa) & \multicolumn{2}{|c|}{$1,00 \pm 0,16(0,45-1,53)$} \\
\hline & Trung vị [QL25- QL75] & \multicolumn{2}{|c|}{$0,97[0,91-1,08]$} \\
\hline \multirow{4}{*}{$\begin{array}{l}\text { Nồng độ } \\
\text { Fibrinogen }\end{array}$} & Giàm $<2 \mathrm{~g} / \mathrm{l}$ & 8 & 13,3 \\
\hline & Bình thường & 52 & 86,7 \\
\hline & $\mathrm{X} \pm \mathrm{SD}$ (tối thiếu- tối đa) & \multicolumn{2}{|c|}{$3,43 \pm 1,32(1,43-7,32)$} \\
\hline & Trung vi [QL25- QL75] & \multicolumn{2}{|c|}{$3,28[2,63-4,05]$} \\
\hline \multirow{4}{*}{ Thời gian APTT } & Tăng $>40$ giây & 1 & 1,7 \\
\hline & Bình thường & 59 & 98,3 \\
\hline & $\mathrm{X} \pm \mathrm{SD}$ (tối thiếu- tối đa) & \multirow{2}{*}{\multicolumn{2}{|c|}{$\frac{28,28 \pm 4,57(14,40-40,30)}{27,75[25,72-30,22]}$}} \\
\hline & Trung vị [QL25- QL75] & & \\
\hline
\end{tabular}

Có 6,7\% BN giảm tỷ lệ Prothrombin <70\%; có 3,3\% BN tăng chỉ số INR >1,3. Có 13,3\% BN giảm nồng độ Fibrinogen $<2 \mathrm{~g} / \mathrm{l}$ và $1,7 \% \mathrm{BN}$ thời gian $\mathrm{APTT}$ kéo dài $>40$ giây.

Bảng 3. Liên quan một số chi số huyết học và mô bệnh hoc ở BN mắc BGDR.

\begin{tabular}{|c|c|c|c|c|}
\hline \multirow{2}{*}{$\begin{array}{c}\text { Giai đoạn } \\
\text { xơ hóa }\end{array}$} & \multicolumn{4}{|c|}{ Chỉ số huyết học $(X \pm S D)$} \\
\hline & SLHC (T/I) & $\mathrm{Hb}(\mathrm{g} / \mathrm{I})$ & $\operatorname{SLBC}(G / I)$ & $\operatorname{SLTC}(\mathbf{G} / \mathbf{I})$ \\
\hline F0 $(n=4)$ & $4,56 \pm 0,70$ & $149,00 \pm 12,30$ & $7,51 \pm 2,26$ & $194,00 \pm 23,90$ \\
\hline$F 1(n=30)$ & $4,40 \pm 0,64$ & $143,40 \pm 19,63$ & $6,57 \pm 1,54$ & $187,14 \pm 69,40$ \\
\hline$F 2(n=7)$ & $4,15 \pm 1,00$ & $132,14 \pm 23,27$ & $8,24 \pm 4,52$ & $256,17 \pm 100,82$ \\
\hline F3 $(n=9)$ & $3,83 \pm 0,64$ & $122,33 \pm 15,44$ & $7,72 \pm 3,16$ & $145,72 \pm 70,75$ \\
\hline $\mathrm{F} 4(\mathrm{n}=10)$ & $4,27 \pm 0,52$ & $139,10 \pm 11,15$ & $7,10 \pm 1,81$ & $129,26 \pm 71,20$ \\
\hline Tương quan & $\begin{array}{c}r=-0,19 ; \\
p>0,05\end{array}$ & 05 & $\begin{array}{l}r=0,10 ; \\
p>0,05\end{array}$ & $\begin{array}{c}r=-0,28 \\
p<0,05\end{array}$ \\
\hline
\end{tabular}

SLHC tương quan thuận với giai đoạn xơ hóa gan trên mô bênh hoc, nhưng sự khác biêt không có ý nghĩa thống kê $(p>0,05)$. Nồng độ Hb và SLTC tương quan nghịch với giai đoạn xơ hóa gan trên mô bệnh học, với hệ số tương quan Pearson $(r=-0,25$ và $r=-0,28)$, sự khác biệt có ý nghĩa thống kê với $p<0,05$.

Bảng 4. Liên quan một số chỉ số đông máu và mô bệnh học ở BN mắc BGDR. 


\begin{tabular}{|c|c|c|c|c|}
\hline \multirow{2}{*}{$\begin{array}{c}\text { Giai đoạn xơ } \\
\text { hóa trên mô } \\
\text { bênh hoc }\end{array}$} & \multicolumn{4}{|c|}{ Chỉ số đông máu ( $X \pm S D)$} \\
\hline & $\begin{array}{c}\text { Prothrombin } \\
(\%)\end{array}$ & $\begin{array}{l}\text { Chỉ số } \\
\text { INR }\end{array}$ & Fibrinogen $(g / I)$ & $\begin{array}{l}\text { APTT } \\
\text { (giây) }\end{array}$ \\
\hline FO $(n=4)$ & $115,33 \pm 4,68$ & $0,93 \pm 0,02$ & $4,01 \pm 2,07$ & $26,87 \pm 2,24$ \\
\hline$F 1(n=30)$ & $113,61 \pm 23,09$ & $0,96 \pm 0,17$ & $3,49 \pm 1,24$ & $28,19 \pm 4,59$ \\
\hline$F 2(n=7)$ & $102,42 \pm 16,51$ & $0,99 \pm 0,09$ & $3,57 \pm 1,89$ & $26,41 \pm 4,46$ \\
\hline$F 3(n=9)$ & $94,04 \pm 19,46$ & $1,05 \pm 0,12$ & $3,13 \pm 1,09$ & $28,22 \pm 4,97$ \\
\hline $\mathrm{F} 4(\mathrm{n}=10)$ & $90,15 \pm 25,52$ & $1,12 \pm 0,21$ & $3,20 \pm 1,08$ & $30,51 \pm 4,78$ \\
\hline $\begin{array}{l}\text { Tương quan } \\
(r ; p)\end{array}$ & $\begin{array}{l}r=-0,42 \\
p<0,001\end{array}$ & $\begin{array}{l}r=0,37 \\
p<0,01\end{array}$ & $\begin{array}{c}r=-0,14 ; \\
p>0,05\end{array}$ & $\begin{array}{l}r=0,17 \\
p>0,05\end{array}$ \\
\hline
\end{tabular}

Tỷ lệ Prothrombin (\%) tương quan nghịch với giai đoạn xơ hóa gan trên mô bệnh học với hệ số tương quan Pearson $r=-0,42(p<0,001)$. Chỉ số INR tương quan thuận với giai đoạn xơ hóa gan trên mô bệnh học với hệ số tương quan Pearson $r=0,37(p<0,01)$. Nồng độ Fibrinogen và thời gian APTT không có tương quan với giai đoạn xơ hóa gan trên mô bệnh học $(p>0,05)$.

\section{BÀN LUẬN}

4.1. Số lượng hông câu và nồng độ hemoglobin. Qua nghiên cứu thây ở $\mathrm{BN}$ mắc BGDR số lượng hồng cầu trung bình là $4,28 \pm$ $0,68(2,34-5,80) \mathrm{T} / \mathrm{l} ;$ Có 45,0\% BN giảm SLHC $<4,2 \mathrm{~T} / \mathrm{l}$. Nồng độ $\mathrm{Hb}(\mathrm{g} / \mathrm{l})$ trung bình là 138,58 $\pm 19,18$ (84- 178) $\mathrm{g} / \mathrm{l}$; Có $16,7 \%$ BN giảm nồng độ $\mathrm{Hb}<120 \mathrm{~g} / \mathrm{l}$. Nồng độ $\mathrm{Hb}$ tương quan nghịch với giai đoạn xơ hóa gan trên mô bệnh học, với hệ số tương quan Pearson $r=-0,25$, sự khác biệt có ý nghĩa thống kê với $p<0,05$ (bảng 1 và bảng 3).

Kết quả này tương tự với nhận xét của một số nghiên cứu trong và ngoài nước ở $\mathrm{BN}$ mắc BGDR [1], [3], [2], [7]. Nghiên cứu của Huang và cs (2017) cho thây nồng độ $\mathrm{Hb}$ của nhóm

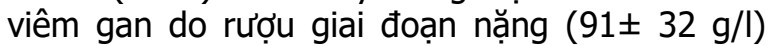
thấp hơn so với nhóm BN GNM $(154 \pm 16.75 \mathrm{~g} / \mathrm{l})$, viêm gan do rượu mức độ nhe $(146 \pm 30 \mathrm{~g} / \mathrm{l})$ và xơ gan do rượu $(113 \pm 32 \mathrm{~g} / \mathrm{l})$, sự khác biệt có ý nghĩa thống kê với $p<0,05$ [7]. Ở Việt Nam, Lê Thị Thu Hiền (2017) thấy BN mắc BGDR có SLHC trung bình là $3,61 \pm 0,89 \mathrm{~T} / \mathrm{l}$, nồng độ $\mathrm{Hb}$ trung bình là $113,46 \pm 30,09 \mathrm{~g} / \mathrm{L}$. Tỷ lệ BN giảm SLHC $<4,2 \mathrm{~T} / \mathrm{I}$ chiếm $69,9 \%$; tỷ lệ $\mathrm{BN}$ giảm nồng độ $\mathrm{Hb}$ $<120 \mathrm{~g} / \mathrm{l}$ chiếm 50,6\%[1]. Lê Quốc Tuấn (2019) thấy giảm SLHC là $66,3 \%$, giảm nồng độ $\mathrm{Hb}$ là 48,4\%[2]. Vũ Thị Thu Trang (2019) nghiên cứu ở bệnh nhân GNM thấy các xét nghiệm huyết học không biến đổi nhiều ở bệnh nhân GNM: chỉ có $11,8 \%$ BN giảm hemoglobin, $16,7 \%$ có giảm SLTC, $17,6 \%$ có tăng bach cầu, đặc biệt có $24,5 \%$ bệnh nhân có $M C V$ tăng. Hầu hết các trường hợp có tăng MCV đều là những đối tượng lạm dụng rượu [3].

4.2. Số lượng tiểu câu. Trong bệnh gan mạn tính, tiểu cầu thường giảm cả về số lượng và chất lượng do giảm sản xuất tiểu cầu trong tủy xương, cường lách, giảm sản xuất thrombopoietin và yếu tố tự miễn. Gia tăng phá hủy tiểu cầu còn do cơ chế miễn dịch do tăng số lượng tiểu cầu gắn IgG trong bệnh gan mạn tính. Trong BGDR, rượu ức chế tủy xương làm giảm sản xuất tiểu cầu và tác dụng trực tiếp trên lipid tiểu cầu [1], [2], [7].

Qua nghiên cứu thấy SLTC ở BN mắc BGDR trung bình là $179,79 \pm 78,90(37,50-413,00)$ G/l; có $35,0 \%$ BN giảm SLTC <140 G/l. SLTC tương quan nghịch với giai đoạn xơ hóa gan trên mô bệnh học, với hệ số tương quan Pearson $r=-$ 0,28 , sự khác biệt có ý nghĩa thống kê với $\mathrm{p}<0,05$ (bảng 1 và bảng 3 ). Số lượng tiểu câu trong nghiên cứu của chúng tôi cũng tương tự kết quả nghiên cứu của một số tác giả khác (bảng 5).

Bảng 5. Số lượng tiểu cầu ở bênh nhân mắc bệnh gan do rươu so với một số nghiên cứu.

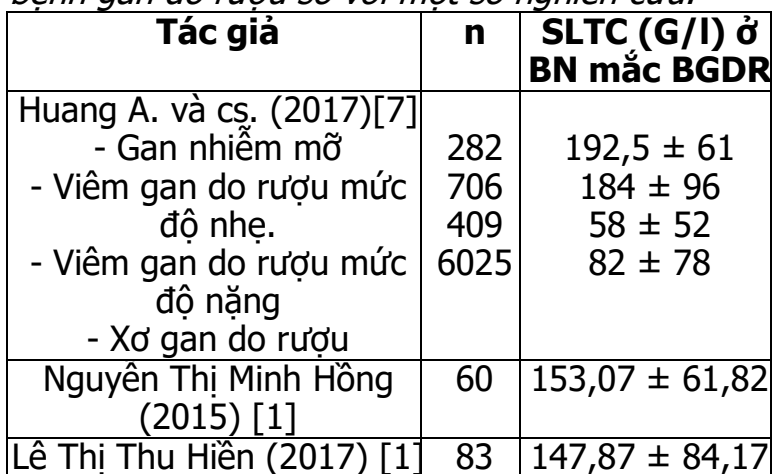

Nghiên cứu của Vijayakumar S. và cs. (2020) ở $119 \mathrm{BN}$ viêm gan do rượu (điểm MELD và Maddrey trung bình là $14,13 \pm 5,17$ và $36,45 \pm$ 29,63 ) thấy số lượng tiểu cầu, độ phân bố tiểu câu (PDW: platelet distribution width), thể tích trung bình của tiểu cầu (MPV: mean platelet volume) và độ nhớt của tiểu cầu (plateletcrit) lần lượt là 194,01 $\pm 178,82 \mathrm{G} / \mathrm{l}, 17,10 \pm 1,21,5,99$ $\pm 0,96$ và $0,14 \pm 0,04$. Độ phân bố tiểu câuu $(P D W)>18$ và thể tích trung bình của tiểu câuu (MPV) có tương quan thuận với điểm MELD. Diện 
tích dưới đường cong ROC cao nhất đối với độ nhớt của tiểu câuu (plateletcrit) là $0,622(p=0,7$; KTC $95 \%=0,500-0,743)$. Các chí số đánh giá tiểu cầu thay đổi đáng kể trong bệnh viêm gan do rượu, nhưng không dư đoán được mức đô viêm gan do rượu nặng có thể do các bệnh kết hợp như viêm tụy, xơ gan và nhiễm khuẩn [8]. Lề Quốc Tuấn (2019) nghiên cứu ở BN mắc BGDR thấy có $53,7 \%$ số BN giảm SLTC [2]. Lư Quốc Hùng (2018) nghiên cứu các $B N$ viêm gan B, C mạn tính thấy SLTC trung bình là 149,1 \pm 82,7 G/I [3]. Trần Thi Khánh Tường (2015) đánh giá tương quan giữa SLTC và giai đoạn xơ hóa gan thấy có mối liên quan nghịch chặt chẽ với hệ số tương quan Spearman $r=-0,39$ [6].

Như vây, giảm SLTC là một yếu tố dư đoán xơ hóa gan ở $\mathrm{BN}$ mắc bênh gan mạn tính nói chung và $B N$ mắc $B G D R$ nói riêng.

4.3. Một số chỉ số đông máu. Qua nghiên cứu ở BN mắc BGDR thấy tỷ lệ Prothrombin (\%) trung bình là $105,58 \pm 23,30 \%$ (từ $54,00 \%$ đến $164,95 \%)$; Có 6,7\% BN giảm tỷ lệ Prothrombin $<70 \%$. Tỷ lệ Prothrombin (\%) tương quan nghịch với giai đoạn xơ hóa gan với hệ số tương quan Pearson $r=-0,42(p<0,001)$. Chỉ số INR trung bình là $1,00 \pm 0,16$ (từ 0,45 đến 1,53 ); có $3,3 \%$ BN tăng chỉ số INR $>1,3$. Chỉ số INR tương quan thuận với giai đoạn xơ hóa gan với hệ số tương quan Pearson $r=0,37(p<0,01)$. Nồng độ Fibrinogen trung bình là $3,43 \pm 1,32 \mathrm{~g} / \mathrm{l}$ (từ 1,43 $\mathrm{g} / \mathrm{l}$ đến $7,32 \mathrm{~g} / \mathrm{l}$ ); Có $13,3 \%$ BN giảm nồng đô Fibrinogen $<2 \mathrm{~g} / \mathrm{l}$. Thời gian APTT trung bình là $28,28 \pm 4,57$ giây (14,40 giây- 40,30 giây); Có $1,7 \%$ BN thời gian APTT kéo dài $>40$ giây. Nồng độ Fibrinogen và thời gian APTT không có tương quan với giai đoạn xơ hóa $(p>0,05)$, (bảng 3.11 và bảng 3.26).

Nhận xét của chúng tôi cũng tương tự kết quả của một số nghiên cứu [3], [6], [8]. Vijayakumar S. và cs. (2020) cho rằng thời gian prothrombin kéo dài là những yếu tố dự báo có ý nghĩa cho bênh viêm gan do rượu [8]. Theo Trần Thị Khánh Tường (2015), chỉ số INR có tương quan thuận với giai đoạn xơ hóa gan: xơ hóa gan càng nặng chỉ số INR càng tăng [6]. Lư Quốc Hùng (2018) nghiên cứu các $B N$ viêm gan $\mathrm{B}, \mathrm{C}$ mạn tính thấy thời gian Prothrombin và chỉ số INR trung bình là 90,3 $\pm 11,2$ và $1,1 \pm 0,2$ [3].

Như vậy, gan có chức năng tổng hợp nhiều protein quan trọng trong quá trình đông máu, cầm máu và tiêu sợi huyết (những yếu tố đông máu: a1 antiplasmin, anti-thrombin, heparin cofactor II, kininogen trọng lượng phân tử cao, prekallikerin, protein), thời gian prothrombin
/IRN kéo dài có thể do chức năng tổng hợp các yếu tố đông máu bị suy giảm hoặc do thiếu vitamin $\mathrm{K}$ do suy chức năng gan. Do vậy, xét nghiệm chức năng đông cầm máu ở bênh nhân viêm gan mạn tính đóng vai trò rất quan trọng.

\section{KẾT LUẬN}

- Có 45,0\% số bệnh nhân mắc bệnh gan do rượu giảm số lượng hồng cầu $<4,2$ T/l; $16,7 \%$ bệnh nhân giảm nồng độ $\mathrm{Hb}<120 \mathrm{~g} / \mathrm{l}$ và $35,0 \%$ số bệnh nhân giảm số lượng <140 G/l. Nồng độ $\mathrm{Hb}$ và số lượng tiểu câu tương quan nghịch với giai đoạn xớ hóa gan trên mô bệnh học, với hệ số tương quan Pearson $(r=-0,25$ và $r=-0,28)$, sự khác biệt có ý nghĩa thống kê với $p<0,05$.

- Có 6,7\% bệnh nhân giảm tỷ lệ Prothrombin $<70 \%$; có $3,3 \%$ bệnh nhân tăng chỉ số INR $>1,3$. Có $13,3 \%$ bệnh nhân giảm nồng độ Fibrinogen $<2 \mathrm{~g} / \mathrm{l}$ và $1,7 \%$ bệnh nhân thời gian APTT kéo dài $>40$ giây. Tỷ lệ Prothrombin (\%) tương quan nghịch với giai đoạn xơ hóa gan trên mô bệnh học với hê số tương quan Pearson $r=$ $0,42(p<0,001)$. Chỉ số INR tương quan thuận với giai đoạn xơ hóa gan trên mô bệnh học với hệ số tương quan Pearson $r=0,37(p<0,01)$.

\section{TÀI LIẸU THAM KHẢO}

1. Nguyễn Thi Minh Hông, Nguyễn Nhược Kim (2015), "Đánh giá tác dụng của viên XG1 điều trì xơ gan do rượu giai đoạn Child - pugh B", Tạp ch Nghiên cứu Y hoc, 94 (2), tr. 110 - 118

2. Lể Thi Thu Hiển (2017), Nghiên cứu môt số đăc điểm lầm sàng, cận lâm sàng và chỉ số chống oxy hóa trong máu ở bệnh nhân mắc bệnh gan do rươu, Luân án Tiến sĩ y học, Đại học YD Thái Nguyên

3. Lư Quổc Hùng (2018), Nighiên cứu đặc điểm lâm sàng, cận lầm sàng và ý nghĩa của Fibroscan, Fibrotest trong chẩn đoán xớ hóa gan ở bệnh nhân viêm gan $B, C$ mạn tính, Luận án Tiến sĩ y học, Học viện Quân y

4. Vữ Thị Thu Trang (2019), Nghiên cứu đặc điểm lâm sàng, một số xét nghiệm, siêu âm và mô bệnh hoc bênh gan nhiếm mõ̃, Luận án Tiến sĩ y học, Viền NCKHYDLS 108

5. Lề Quốc Tuấn (2019), Nghiên cứu đặc điểm lâm sàng, cận lâm sàng và nồng độ một số cytokin huyêt tương trên bệnh nhân mắc bệnh gan man do rượu, Luận án Tiến sĩ y học, Đại học YD Thái Nguyên.

6. Trân Thị Khánh Tường (2015), Nghiên cứu giá trị chẩn đoán xơ hóa gan bằng phối hợp kỹ thuật ARFI với APRI ở các bệnh nhân viêm gan mạn, Luâan án Tiến sĩ y học, Đại học YD Huế.

7. Huang A., Chang B., Sun Y., et al (2017), "Disease spectrum of alcoholic liver disease in Beijing 302 Hospita I from 2002 to 2013", 96 (7), pp. 1-5.

8. Vijayakumar S., Viswanathan S., Jain D. (2020), "Utility of platelet indices in alcoholic hepatitis: a retrospective study", Porto Biomed J., 5(5): e082. 


\title{
GIÁ TRI PHƯƠNG PHÁP CHỤP XQUANG PHỔ HAI MỨC NĂNG LƯỢNG CÓ TIÊM THUỐC CẢN QUANG TRONG CHẨN ĐOÁN UNG THƯ TUYỂN VÚ
}

\author{
Trần Thị Bích Hạnh*, Nguyễn Minh Hải**, Vũ Thu Thủy*, \\ Trần Thị Phương Thảo*, Lê Thị Thanh Xuân*
}

\section{TÓM TẮT}

Mục tiêu: Đánh giá giá trị chẩn đoán ung thư vú của phương pháp chup $X$ quang phổ hai mức năng lượng có tiểm thuốc cản quang (CESM) so với kết quả mồ bệnh họ. Phương pháp: Mô tả cắt ngang, hồi cứu. Kết quả: Nghiên cứu trên 50 bệnh nhân có tổn thương u vú được chụp CESM, độ tuổi trung bình là $49,86 \pm 12,06$. Hình ả̉nh khối đa thùy trên CESM có độ nhạy $71,4 \%$, độ đặc hiệu $68,2 \%$, giá trị dự báo dương tính $74,1 \%$ và giá trị dự báo âm tính $65,2 \%$, độ chính xác $60 \%$. Hình ảnh đường bờ không rỗ nét trên CESM có độ nhạy 53,6\%, độ đặc hiệu 77,3\%, giá trị dự báo dương tính $75 \%$ và giá trị dự báo âm tính $56,7 \%$, độ chính xác $64 \%$. Hình ảnh u xâm lấn trên CESM có độ nhạy 42,9\%, độ đặc hiệu 95,5\%, giá trị dự báo dương tính $92,3 \%$ và giá trị dự báo âm tính $56,8 \%$, độ chính xác $66 \%$. Hình ảnh ngấm thuốc trên CESM có độ nhay $89,3 \%$, đô đăc hiệu $90,9 \%$, giá trị dự báo dương tính $92,6 \%$ và giá trị dự báo âm tính $87 \%$, độ chính xác $90 \%$. Phân loại BIRADS $\geq 4$ trên CESM có độ nhạy 96,4\%, độ đặc hiệu 22,7\%, giá trị dự báo dưởng tính $61,4 \%$ và giá trị dự báo âm tính 83 ,3\%, độ chính xác 64\%. Kết luận: Hình ảnh Chụp XQ tuyến vú phổ hai mức năng lưởng CESM đánh giá hiệu quả những tổn thương tăng đậm độ, thể hiện rõ ràng tính chất khối, ít bỏ sót tổn thương, do đó có giá trị trong việc chẩn đoán ung thư vú với các đối tượng có tuyến vú đâm đăc.

Tư khóa: U vú, X quang phổ hai mức năng lượng có tiêm thuốc cản quang

\section{SUMMARY \\ VALUE OF CONTRAST ENHANCED SPECTRAL MAMMOGRAPHY IN DIAGNOSIS OF BREAST CANCER}

Objectives: To evaluate the diagnostic values of contrast enhanced spectral mammography (CESM) in patient withbreast cancer compared with histopathological results. Methods: Retrospective, cross-sectional study. Results: Studying on 50 patients with breast tumor lesions undergoing CESM, the average age was $49.86 \pm 12.06$. Multi-lobular mass on CESM had a sensitivity of $71.4 \%$, specificity of $68.2 \%$, a positive predictive value of $74.1 \%$ and a negative predictive value of $65.2 \%$, with an accuracy of $60 \%$. The indistinct margin mass on CESM had a

\footnotetext{
*Bệnh viện TWQĐ 108.

**Bênh viện 103, HVQY.

Chịu trách nhiệm chính: Trân Thị Bích Hạnh

Email: nmhaidr@gmail.com

Ngày nhận bài: 12/7/2021

Ngày phản biện khoa học: 10/8/2021

Ngày duyệt bài: 25/8/2021
}

sensitivity of $53.6 \%$, a specificity of $77.3 \%$, a positive predictive value of $75 \%$ and a negative predictive value of $56.7 \%$, with an accuracy of $64 \%$. Invasive tumor on CESM X-ray had a sensitivity of $42.9 \%$, a specificity of $95.5 \%$, a positive predictive value of $92.3 \%$ and a negative predictive value of $56.8 \%$, with an accuracy of $66 \%$. The image of enhancement on CESM had a sensitivity of $89.3 \%$, a specificity of $90.9 \%$, a positive predictive value of $92.6 \%$ and a negative predictive value of $87 \%$, with an accuracy of $90 \%$. The BIRADS classification $\geq 4$ on CESM has a sensitivity of $96.4 \%$, a specificity of $22.7 \%$, a positive predictive value of $61.4 \%$ and a negative predictive value of $83.3 \%$, with an accuracy of $64 \%$. Conclusion: Image of CESM effectively evaluates hypedense lesions, clearly showing the mass nature, less omission of lesions, thus valuable in diagnosing breast cancer with subjects with dense mammary glands.

Keywords: Breast tumor, contrast enhanced spectral mammography.

\section{I. ĐĂT VẤN ĐỀ}

CESM (Contrast-enhanced spectral mammography) Là một phương pháp chụp $X$ quang tuyến vú đặc biệt, thường được chỉ định trên những bệnh nhân có hình ảnh vú trên phim 2D không kết luận được hoặc nghi ngờ ác tính. CESM sử dụng chất cản quang có i-ốt để phát hiện những vùng tăng tưới máu trong vú, thường là các khối ung thư vú có nguồn cấp máu nhiều hơn tổ chức tuyến vú bình thường $[1,2]$. Với chụp XQ 2 D tuyến vú thông thường dể chẩn đoán đối với những bệnh nhân tuyến vú mõ (typ $A, B)$, với những bệnh nhân tuyến vú đặc (typ C, D) nhu mô tuyến đậm đặc, che lấp các tổn thương khối tăng đậm độ, hạn chế đánh giá tính chất khối (bờ viền, co kéo...) dẫn đến bỏ sót và đánh giá thiếu tính chất tổn thương, và đây cũng là hạn chế rất hay gặp trong sàng lọc ung thư vú ở những tộc người châu Á. Điều quan trọng nhất, với Xquang tuyến vú $2 D$ thông thường không đánh giá được tính chất tăng sinh mạch của khối u là một trong những đăc tính cơ bản và quan trọng trong chẩn đoán phân biệt khối u lành tính hay ác tính. Trong một nghiên cưu hôi cứu được công bố gân đây trên tạp chí Radiology (2019), Sung và CS đã đánh giá CESM như một phương pháp thay thế cho chụp nhũ ảnh tiêu chuẩn để tâm soát ung thư vú [3]. Tại Việt Nam hiện nay chưa có nhiều nghiên cưu về vấn đề này, vì vậy chúng tôi thực hiện nghiên cứu với 
mục tiêu: Đánh giá giá trị chẩn đoán ung thư vú của phương pháp chup X quang CESM so với kết quả mô bệnh học.

\section{II. ĐỐI TƯƠNG VÀ PHƯƠNG PHÁP NGHIÊN CứU}

2.1. Đối tượng nghiên cứu. Các trường hợp phụ nữ mọi lứa tuổi đến khám tại bệnh viện TƯQĐ 108, trong thời gian từ tháng 04/2017 12/2020, có tổn thương vú (sờ thây được hoặc không sờ thấy), có chỉ định chụp XQ tuyến vú có tiêm thuốc cản quang.

\subsection{Phương pháp nghiên cứu}

Loại hình nghiên cứu: Nghiên cứu mô tả cắt ngang, hồi cứu.

\section{KẾT QUẢ NGHIÊN CỨU}

Bảng 1. Phân bố bệnh nhân theo nhóm tuổi

\begin{tabular}{|c|c|c|c|c|c|c|c|}
\hline \multirow{2}{*}{ Nhóm tuối } & \multicolumn{2}{c|}{ Lành GPB } & \multicolumn{2}{c|}{ Ac tính } & \multicolumn{2}{c|}{ Tống } & \multirow{2}{*}{ p } \\
\cline { 2 - 7 } & $\mathbf{n}$ & $\mathbf{\%}$ & $\mathbf{n}$ & $\mathbf{\%}$ & $\mathbf{n}$ & $\mathbf{\%}$ & \\
\hline$<30$ tuối & 1 & 4,55 & 0 & 0 & 1 & 2 & \\
\hline $30-44$ tuối & 11 & 50 & 5 & 17,85 & 16 & 32 & $>05$ \\
\hline $45-60$ tuối & 7 & 31,82 & 16 & 57,14 & 23 & 46 & \\
\hline$>60$ tuối & 3 & 13,64 & 7 & 25 & 10 & 20 & \\
\hline Tống & 22 & 44 & 28 & 56 & $49,86 \pm 12,09$ & \\
\hline
\end{tabular}

Nhân xét: Nhóm tuối hay gặp nhất là từ 45-60 tuối chiếm 46\%, nhóm dưới 30 tuối chỉ có 1 BN. Độ tuối trung bình của bệnh nhân là 49,86 $\pm 12,06$. Nhóm có kết quả giải phẫu bệnh ác tính lớn nhất là nhóm 45-60 tuổi, chiếm 57,14\%.

Bảng 2. Giá trị chẩn đoán dựa trên hinh dang đa thùy trên XQ CESM

\begin{tabular}{|c|c|c|c|}
\hline Đa thùy MBH & Ác tính & $\begin{array}{l}\text { Lành } \\
\text { tính }\end{array}$ & Tổng \\
\hline Có & 20 & 7 & 27 \\
\hline Không & 8 & 15 & 23 \\
\hline Tổng số & 28 & 22 & 50 \\
\hline $\begin{array}{r}71,4 \%, S \\
=\end{array}$ & $\begin{array}{l}68,2 \% \\
\%, \text { Acc }\end{array}$ & $\begin{array}{l}V=74 \\
60 \%\end{array}$ & $\%, \mathrm{NPV}$ \\
\hline
\end{tabular}

Nhân xét: Hình ảnh hình dạng khối u đa thùy trên XQ CESM có độ nhạy $71,4 \%$, độ đặc hiệu $68,2 \%$, giá trị dự báo dương tính $74,1 \%$ và giá tri dự báo âm tính $65,2 \%$, đô chính xác $60 \%$.

Bảng 3. Giá trị chẩn đoán dựa trên đường bờ không rô nét trên XQ CESM

\begin{tabular}{|c|c|c|c|}
\hline Không rố nét & $\begin{array}{c}\text { Ac } \\
\text { tính }\end{array}$ & $\begin{array}{l}\text { Lành } \\
\text { tính }\end{array}$ & Tổng \\
\hline Có & 15 & 5 & 20 \\
\hline Không & 13 & 17 & 30 \\
\hline Tổng số & 28 & 22 & 50 \\
\hline
\end{tabular}

Nhân xét: Hình ảnh đường bờ không rõ nét trên XQ CESM có độ nhạy 53,6\%, độ đặc hiệu $77,3 \%$, giá trị dự báo dương tính $75 \%$ và giá trị dự báo âm tính $56,7 \%$, độ chính xác $64 \%$.

Bảng 4. Giá trị chẩn đoán dựa trên hình ảnh vôi hóa trên XQ CESM
Tiêu chuẩn lựa chọn. Tất cả phụ nữ đến khám, phát hiện tổn thương ở vú, được phân loại BI-RADS 3,4,5 trên chụp XQ tuyến vú $2 \mathrm{D}$ có chỉ đinh chup CESM, sau đó được sinh thiết tổn thương, có kết quả xét nghiệm mô bệnh học, đồng ý tham gia nhóm nghiên cứu.

Tiêu chuẩn loại trừ. Bệnh nhân không có kết quả xét nghiệm mô bệnh học, không có đầy

Nội dung nghiên cứu: Tính giá trị chẩn đoán của các đặc điểm khối u vú dựa trên hình dang, đường bờ, tính chất vôi hóa, xâm lấn, đặc điểm ngấm thuốc, hạch trên XQ CESM đủ hồ sơ bênh án.

\begin{tabular}{|c|c|c|c|}
\hline Vôi hóa MBH & $\begin{array}{c}\text { Ác } \\
\text { tính }\end{array}$ & $\begin{array}{l}\text { Lành } \\
\text { tính }\end{array}$ & Tổng \\
\hline Có & 15 & 9 & 24 \\
\hline Không & 13 & 13 & 26 \\
\hline Tống số & 28 & 22 & 50 \\
\hline
\end{tabular}

Nhận xét: Hình ảnh vôi hóa trên XQ CESM có độ nhạy 53,6\%, độ đặc hiệu 59,1\%, giá trị dự báo dương tính $62,5 \%$ và giá trị dự báo âm tính $50 \%$, độ chính xác $56 \%$.

Báng 5. Giá trị chẩn đoán dựa trên tình trạng hạch trên XQ CESM

\begin{tabular}{|c|c|c|c|}
\hline Hạch MBH & Ác tính & $\begin{array}{c}\text { Lành } \\
\text { tính }\end{array}$ & Tổng \\
\hline Có & 13 & 7 & 20 \\
\hline Không & 15 & 15 & 30 \\
\hline Tống số & $\mathbf{2 8}$ & $\mathbf{2 2}$ & $\mathbf{5 0}$ \\
\hline Sn = 46,4\%, Sp =68,2\%, PPV = 65\%, NPV = \\
$50 \%$, ACc = 56\% \\
\hline \multicolumn{4}{|c|}{} \\
\hline
\end{tabular}

Nhận xét: Tình trang hach trên XQ CESM có độ nhạy $46,4 \%$, độ đặc hiệu $68,2 \%$, giá trị dự báo dương tính $65 \%$ và giá trị dự báo âm tính $50 \%$, độ chính xác $56 \%$.

Bảng 6. Giá trị chẩn đoán dựa trên tình trạng xâm lấn trên XQ CESM

\begin{tabular}{|c|c|c|c|}
\hline Xâm lấn MBH & $\begin{array}{c}\text { Ac } \\
\text { tính }\end{array}$ & $\begin{array}{c}\text { Lành } \\
\text { tính }\end{array}$ & Tổng \\
\hline Có & 12 & 1 & 13 \\
\hline
\end{tabular}




\begin{tabular}{|c|c|c|c|}
\hline Không & 16 & 21 & 37 \\
\hline Tống số & $\mathbf{2 8}$ & $\mathbf{2 2}$ & $\mathbf{5 0}$ \\
\hline $\begin{array}{c}\text { Sn }=42,9 \%, \mathrm{Sp}=95,5 \%, \mathrm{PPV}=92,3 \%, \text { NPV } \\
=56,8 \%, \text { Acc }=66 \%\end{array}$ \\
\hline
\end{tabular}

Nhân xét: Hình ảnh xâm lấn trên XQ CESM có độđặc hiệu cao 95,5\%.

Bảng 7. Giá trị chẩn đoán dựa trên tình trạng ngấm thuốc trên XQ CESM

\begin{tabular}{|c|c|c|c|}
\hline Ngấm thuốc & Ác tính & $\begin{array}{l}\text { Lành } \\
\text { tính }\end{array}$ & Tổng \\
\hline Có & 25 & 2 & 27 \\
\hline Không & 3 & 20 & 23 \\
\hline Tống số & 28 & 22 & 50 \\
\hline
\end{tabular}

Nhận xét: Hình ảnh ngấm thuốc trên $\mathrm{XQ}$ CESM có độ nhạy và độ đặc hiệu cao 89,3\%, độ đặc hiêu $90,9 \%$.

Bảng 8. Giá trị chẩn đoán dựa trên phân loại $B I-R A D S$ trên XQ CESM với BI-RADS $\geq 4$

\begin{tabular}{|c|c|c|c|}
\hline Birads $\geq 4$ & Ác tính & $\begin{array}{l}\text { Lành } \\
\text { tính }\end{array}$ & Tổng \\
\hline Có & 27 & 17 & 44 \\
\hline Không & 1 & 5 & 6 \\
\hline Tống số & 28 & 22 & 50 \\
\hline
\end{tabular}

Nhận xét: Phân loại BIRADS $\geq 4$ trên XQ CESM có độ nhạy cao 96,4\%.

\section{BÀN LUÂN}

Theo kết quả chúng tôi thu được, hình ảnh uđa thùy trên XQ CESM có độ nhạy $71,4 \%$, độ đặc hiệu $68,2 \%$, giá trị dự báo dương tính $74,1 \%$ và giá trị dự báo âm tính $65,2 \%$, đô chính xác $60 \%$. Theo tác giả Nguyễn Văn Thắng, tổn thương có hình đa diện của các tổn thương UTV trên cả $X Q$ và siêu âm đều cao $(80,4 \%$ và 78,3\%), nhưng độ đặc hiệu không cao, trên XQ $71,43 \%$ và trên SA $50 \%$ [5]. Độ đặc hiệu của dấu hiệu này trong nghiên cứu của chúng tôi còn thấp, điều này được giải thích do đa phần $\mathrm{BN}$ của chúng tôi có mô vú thuộc týp vú đặc, do đó sự chồng tuyến đã phần nào gây khó khăn cho việc nhận định hình thái tổn thương.

Hình ảnh đường bờ không rõ nét trên $X Q$ CESM có độ nhạy 53,6\%, độ đặc hiệu 77,3. Theo tác giả Constantini trong nghiên cứu năm 2006 cho thấy dấu hiệu tổn thương có đường bờ nham nhở hình sao có giá trị trong chẩn đoán UTV, độ nhạy 90,6\%, độ đặc hiệu 87,8\% [6]. Hình ảnh vôi hóa trên XQ CESM có độ nhạy $53,6 \%$, độ đặc hiệu 59,1\%, giá trị dự báo dương tính $62,5 \%$ và giá trị dự báo âm tính $50 \%$, độ chính xác $56 \%$. Cũng theo tác giả Nguyễn Văn
Thắng, dấu hiệu vôi hóa trên XQ cho độ nhạy $34,78 \%$, độ đặc hiệu $75 \%$. Trên siêu âm, độ nhạy và độ đặc hệu lần lượt là $30,43 \%$ và $89,29 \%[5]$.

Với hình ảnh $X Q$ và siêu âm bình thường không có bệnh lý đôi khi chúng ta vẫn quan sát thấy hạch nách và đó là hình ảnh hạch nách bình thường. Trên siêu âm hạch bình thường là những cấu trúc hình bầu dục, hình chữ $C$ giảm âm ở ngoại vi (vỏ hạch) và tăng âm ở trung tâm (mõ rốn hạch), vỏ hạch thường dày $<3 \mathrm{~mm}$ và đều. Trên $X Q$ là những cấu trúc hình tròn hay hình bầu dục, kích thước thường dưới $1 \mathrm{~cm}$, đậm độ cản quang mức độ trung bình, vùng trung tầm thấu quang hơn so với ngoại vi đó là biểu hiện bình thường của cấu trúc mõ̃ rốn hạch. Kết quả nghiên cứu của chúng tôi, tình trạng hạch trên XQ CESM có độ nhạy 46,4\%, độ đặc hiệu $68,2 \%$, giá trị dự báo dương tính $65 \%$ và giá trị dự báo âm tính $50 \%$, độ chính xác $56 \%$.

Hình ảnh xâm lấn trên XQ CESM có độ nhạy 42,9\%, độ đặc hiệu 95,5\%, giá trị dự báo dương tính $92,3 \%$ và giá trị dự báo âm tính $56,8 \%$, độ chính xác $66 \%$. Constatini (2006), nghiên cứu cho thấy dấu hiệu xâm lấn trên siêu âm cho giá trị dự báo dương tính $86 \%$, tác giả cũng cho thấy rằng dấu hiệu này thường đi kèm theo các hình ảnh tổn thương khối u có hình đa diện, khó định dạng, tổn thương có bờ nham nhở không đều, hình sao. Đặc biệt hơn nữa nếu tổn thương có chỉ số $D / W>1$. Dấu hiệu có biểu hiên xâm lấn là hình ảnh dày lên của cấu trúc da và mô dưới da, tác giả cũng nhấn mạnh rằng đây là dấu hiệu chính để phân biệt một tổn thương lành tính hay ác tính [6]. Theo Nguyễn Văn Thắng, giá trị chẩn đoán UTV của dấu hiệu xâm lấn trên XQ là $\mathrm{Se}=$ $8,7 \%, \mathrm{Sp}=100 \%$, PPV $=100 \%$ [5].

Hình ảnh ngấm thuốc trên XQ CESM có độ nhạy $89,3 \%$, độ đặc hiệu $90,9 \%$, giá trị dự báo dương tính $92,6 \%$ và giá trị dự báo âm tính $87 \%$, độ chính xác $90 \%$.Phân loại BIRADS $\geq 4$ trên XQ CESM có độ cao 96,4\%.Nghiên cứu của Berg W.A. và CS (2004) cho thấy rằng $X Q$ có độ nhay $100 \%$ trong chẩn đoán UTV ở nhóm có tuyến vú mõ hóa cao, 45\% ở nhóm mô vú đậm đặc [7]. Theo Nguyễn Văn Thắng độ nhạy trong chẩn đoán UTV của XQ là 89,13\% [5].

So với một số nghiên cứu trước độ đặc hiêu có phần thấp hơn, điều này có thể do phần lớn các đối tượng nghiên cứu của chúng tôi tới viện vì tự phát hiện thấy tổn thương khối tại vú, 28 khối u ác tính và 22 khối u lành. Chính do phần lớn $\mathrm{BN}$ đến đều thấy có bất thường tại vú nên khi chụp XQ chúng tôi gặp rất nhiêu các hình 
ảnh bất thường cân phải phân biệt
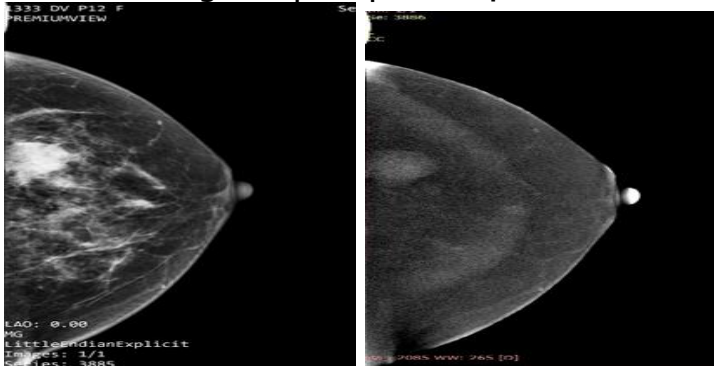

Hình ảnh minh họa khối u vú phải với tư thễ chụp từ trên xuống, trước và sau tiêm thuốc cản quang, xuất hiện nốt ngấm thuốc nhỏ hơn phía trước, ngay sau núm vú. Kết quả mô bệnh học là ung thư biểu mô ống xâm nhập.

\section{KẾT LUÂ̂N}

Hình ảnh Chụp XQ tuyến vú phổ hai mức năng lượng CESM đánh giá hiệu quả những tổn thương tăng đậm độ, thể hiện rõ ràng tính chất khối, ít bỏ sót tổn thương, do đó có giá trị trong việc chẩn đoán ung thư vú với các đối tượng có tuyến vú đậm đặc.

TÀl LIỆ THAM KHẢO
1. Nada A.M.A.M., Hamdi R., Shokry A. (2017). Dual energy contrast enhanced soft tissue digital mammography versus ultrasound elastography in the evaluation of breast masses. The Egyptian Journal of Radiology and Nuclear Medicine, 48(4), 1179-1186.


(2009). Contrast-enhanced digital mammography. Eur J Radiol, 69(1), 34-42.

3. Sung J.S., Lebron L., Keating D. et al (2019). Performance of Dual-Energy Contrast-enhanced Digital Mammography for Screening Women at Increased Risk of Breast Cancer. 293(1), 81-88.

4. Spak D.A., Plaxco J.S., Santiago L. et al (2017). BI-RADS((R)) fifth edition: A summary of changes. Diagn Interv Imaging, 98(3), 179-190.

5. Nguyến Văn Thắng (2013), Nghiên cứu giá trị chẩn đoán ung thư vú của chup $X$ quang kêt hợp siêu âm tuyến vú, Luận văn thạc sĩ y học, Đại học Y Hà Nội.

6. Costantini M., Belli P., Lombardi R. et al (2006). Characterization of solid breast masses: use of the sonographic breast imaging reporting and data system lexicon. J Ultrasound Med, 25(5), 649-659; quiz 661.

7. Berg W.A., Gutierrez L., NessAiver M.S. et al (2004). Diagnostic accuracy of mammography, clinical examination, US, and MR imaging in preoperative assessment of breast cancer. Radiology, 233(3), 830-849.

\section{PHÂN TÍCH CHI PHÍ ĐIỀU TRI BÊNH PHỔI TẮC NGHẼN MAN TÍNH THEO QUAN ĐIỂM NGƯỜI CHI TRẢ TẠI BỆNH VIỆN QUẦN 11}

\section{Dương Thái Bình ${ }^{1}$, Đặng Thị Ngọc² ${ }^{2}$ Nguyễn Thị Xuân Liễu ${ }^{3}$, Trương Thị Thu Hoàn ${ }^{2}$, Nguyễn Thị Thu Thuỷ ${ }^{1}$}

\section{TÓM TẮT}

Mở đâu: Bệnh phổi tắc nghẽn mạn tính (COPD Chronic Obstructive Pulmonary Disease) hiện nay đang trở thành một trong những vấn đề bệnh lý nghiêm trong gây ra bênh tât và tử vong hàng đầu trên thế giới cũng như tại Việt Nam. Trên thế giới đã có những nghiên cứu nhằm phân tích chi phí trong điều trị COPD và đây cũng là 1 trong những bước quan trọng nhằm cung cấp cái nhìn tổng quan về gánh năng kinh tế của bênh tại Việt Nam. Mục tiêu: Phân tích chi phí điều trì bểnh phổi tắc nghẽn man tính theo quan điểm ngườ chi trả tại bệnh viện Quận 11. Phương pháp nghiên cứu: Mổ tả cắt ngang dựa trên dữ liêu thu thập từ hồi cứu hồ sơ bệnh án và phỏng vấn toàn bộ người bệnh

${ }^{1}$ Đại học Y Dược Thành phố Hồ Chi Minh

²Bênh viện Quận 11, Thành phố Hồ Chí Minh

${ }^{3}$ Trường Đại học Nguyễn Tất Thành

Chiu trách nhiểm chính: Nguyễn Thị Thu Thuỷ

Email: nguyenthuthuy@ump.edu.vn

Ngày nhận bài: 14.6.2021

Ngày phản biện khoa học: 9.8.2021

Ngày duyệt bài: 18.8.2021 phổi tắc nghẽn mạn tính đến khám và điều trị tại Bệnh viện Quận 11 trong thời gian từ tháng 2 đến hết tháng 5 năm 2021 thỏa tiêu chí lựa chon và loai trừ. Nghiên cứu được thực hiên theo quan điểm người chi trả bao gồm cơ quan chi trả BHYT và người bệnh vì vậy các chi phí trực tiếp (y tế, ngoài y tế) và gián tiếp được đánh giá. Kết quả: Chi phí mỗi tháng điều trị tăng dần theo mức độ nặng của bênh với giá trị lần lướt là 78.478,22; 214.303,02; 267.937,06; 713.248,11 đồng cho các giai đoan từ GOLD A đến GOLD D. Như vây chi phí điều trị giai đoạn GOLD D gấp 9,09 lần giai đoạn GOLD A. Về cấu trúc, chi phí trực tiếp y tế chiếm tỷ lê cao nhất ở cả 4 giai đoan bênh, tiếp theo là chi phí gián tiếp và thấp nhất là chi phí trực tiếp ngoài y tế. Kết luân: Nghiên cứu ghi nhân tổng chi phí 1 tháng điều trị của người bệnh COPD tăng dần theo mức độ nặng của bệnh và chi phí trực tiếp y tế chiếm tỷ lề cao nhất.

Tư khoá: bênh phổi tắc nghẽn mạn tính, chi phí điều trị, bệnh viện quận 11

\section{SUMMARY \\ ANALYZE TREATMENT COST OF CHRONIC OBSTRUCTIVE PULMONARY DISEASE}




\section{FROM THE PAYERS' PERSPECTIVE IN DISTRICT 11 HOSPITAL}

Background: Chronic Obstructive Pulmonary Disease (COPD) is now becoming one of the medical problems leading to morbidity and mortality in the world as well as in Vietnam. Worldwide, researches on the treatment cost of COPD have been conducted in many countries and this is also one of the important to provide an overview of COPD treatment in Vietnam. Objectives: Analyzing the cost of treatment of chronic obstructive pulmonary disease from the payer perspective in district 11 hospital. Method: Crosssectional descriptive study based on data collected from retrospective medical records and interviews with COPD inpatients and outpatients, meeting the selection criteria of District 11 Hospital during the period from February to the end of May 2021. The research was conducted from the payers' perspective including the health insurance payer and the patient, so direct (medical, non-medical) and indirect costs were assessed. Results: The monthly treatment cost increased gradually according to the severity of the disease with the value of $78,478.22$; 214,303.02; $267,937.06$ and VND $713,248.11$ for stages from GOLD A to GOLD D; respectively. Thus, the cost of treatment for GOLD D stage is 9.09 times higher than that of GOLD A stage. In terms of structure, direct medical costs accounted for the highest proportion in all 4 disease stages, followed by indirect costs and non-medical direct costs was lowest. Conclusions: The study noted that the total monthly cost of treatment of COPD increased gradually with the severity of the disease and direct medical costs accounted for the highest proportion.

Keywords: chronic obstructive pulmonary disease, cost of treatment, district 11 hospital.

\section{I. ĐĂ̆T VẤN ĐỀ}

Bệnh phổi tắc nghẽn mạn tính (COPD Chronic Obstructive Pulmonary Disease) hiện nay đang trở thành một trong những vân đề bệnh lý nghiêm trọng gây ra bệnh tật và tử vong hàng đầu trên thế giới cũng như tại Việt Nam. COPD được ghi nhận là nguyên nhân gây tử vong thứ năm trên toàn thế giới, được dự đoán sẽ xếp thứ ba thế giới vào năm 2020 [1]. Tỷ lệ mắc và tử vong cao do COPD về cơ bản làm tăng gánh nặng tài chính cho ngân sách nhà nước [2]. Ở châu Âu, chi phí cho các bênh hô hấp ước tính bằng $6 \%$ ngân sách được phân bổ cho chăm sóc sức khỏe. Trong số này, 56\% được phân bổ cho việc điều trị bệnh nhân COPD, tạo ra chi phí khoảng 38,7 tỷ EURO hàng năm và gây mất 66.155 ngày làm việc trên tổng số 100.000 dân, chiếm $62,4 \%$ tổng số người nghỉ việc liên quan đến công việc. Tồng chi phí liên quan đến COPD ở Mỹ ước tính khoảng 36,1 tỷ USD, trong đó 20,9 tỷ là chi phí trực tiếp $[3,4]$. Ở Ba Lan, chi phí điêu trị đợt cấp COPD trung bình tại bệnh viện là gần 1.200 EURO, chi phí trực tiếp y tế chiếm 70\% [5]. Việc phân tích chi phí điều trị COPD là vấn đề cấp bách nhằm đánh giá tác động về mă̆t kinh tế của căn bênh này đối với người bệnh và cộng đồng. Tuy nhiên tại Việt Nam nghiên cứu tương tự vẫn chưa được thực hiện. Vì vậy nghiên cứu được thực hiện nhằm phân tích giá trị và cấu trúc chi phí điều trị bệnh COPD theo quan điểm người chi trả.

\section{II. ĐỐI TƯợNG VÀ PHƯƠNG PHÁP NGHIÊN CỨU}

Đối tượng nghiên cứu. Người bệnh COPD điều trị tại bệnh viện Quận 11.

Phương pháp nghiển cứu. Mô tả cắt ngang dựa trên dữ liệu hồi cứu hồ sơ bệnh án và phỏng vẩn trực tiếp người bệnh bằng phiếu phỏng vấn. Chi phí điều trị COPD được đánh giá bao gồm chi phí điều trị nội trú và ngoai trú của người bênh COPD cùng với số đợt nội trú và ngoại trú của người bệnh trung bình trong 1 tháng. Nghiên cứu thực hiên trên quan điểm người chi trả vì vây chi phí điều tri nội trú và ngoai trú bao gồm chi phí trực tiếp y tế (CP TTYT), chi phí trực tiếp ngoài y tế (CP TTNYT) và chi phí gián tiếp (CP GT). Trong đó chi phí trực tiếp y tế bao gồm các chi phí dich vu y tế và chi phí thuốc. Chi phí trực tiếp ngoài y tế gồm chi phí di chuyển, ăn uống và các chi phí khác; chi phí gián tiếp bao gồm thu nhập mất đi của người bệnh và người thân trong quá trình điều trị.

Mẫu nghiên cứu. Tất cả người bệnh COPD đến khám ngoại trú và/hoặc điêu trị nội trú tại Bênh viện Quận 11 từ tháng 2 đên hêt tháng 5 nẳm 2021 thoả mãn tiêu chí chọn mẫu.

\section{Tiêu chí lựa chon:}

- Người bệnh từ đủ 18 tuổi trở lên

- Người bệnh nghe, hiểu và viết được tiếng Việt

- Người bệnh đồng ý tham gia nghiên cứu

\section{Tiêu chí loại trư:}

- Người bệnh không cung cấp đầy đủ các thông tin cơ bản của phiếu khảo sát

- Người bệnh bỏ điều trị hoặc tự ý chuyển viện trong quá trình điêu trị

- Người bệnh có những bệnh mạn tính nặng kèm theo ảnh hưởng đến chi phí điều trị (ung thư, suy thận, viêm gan)

Thống kê và xử lý dữ liệu. Số liệu nghiên cứu được xử lý và thống kê bằng phần mềm thống kê SPSS 26 và Microsoft Excel 2016 với các phương pháp thống kê phù hợp. Số liệu được trình bày ở dạng hình và bảng.

\section{KẾT QUẢ NGHIÊN CứU}

Đặc điểm mẫu nghiên cứu. Mẫu nghiên cứu ngoại trú 
Khảo sát mẫu nghiên cứu gồm 122 người nghiên cứu ghi nhận đặc điểm mẫu nghiên cứu bệnh ngoại trú COPD tại bệnh viện Quận 11, trình bày trong bảng 1 .

Bảng 1. Đặc điểm mẫu nghiên cứu ngoại trú

\begin{tabular}{|c|c|c|c|c|c|}
\hline \multicolumn{2}{|c|}{ Đăc điếm } & T'ân số (\%) & \multicolumn{2}{|c|}{ Đặc điếm } & Tân số (\%) \\
\hline \multirow{2}{*}{$\begin{array}{l}\text { Giới } \\
\text { tính }\end{array}$} & Nũ̃ & $8(6,6)$ & \multirow{4}{*}{$\begin{array}{l}\text { Nhóm } \\
\text { bệnh }\end{array}$} & GOLD A & $16(13,1)$ \\
\hline & Nam & $114(93,4)$ & & GOLD B & $26(21,3)$ \\
\hline \multirow{3}{*}{ BHYT } & $80 \%$ & $95(77,9)$ & & GOLD C & $22(18,0)$ \\
\hline & $95 \%$ & $5(4,1)$ & & GOLD D & $58(47,5)$ \\
\hline & $100 \%$ & $22(18,0)$ & \multirow{4}{*}{$\begin{array}{l}\text { Chỉ số } \\
\text { FEV1 }\end{array}$} & $\geq 80 \%$ & $5(4,1)$ \\
\hline \multirow{5}{*}{$\begin{array}{l}\text { Nghề } \\
\text { nghiệp }\end{array}$} & Buôn bán/Tự kinh doanh & $4(3,3)$ & & $50-79 \%$ & $23(18,9)$ \\
\hline & $\begin{array}{l}\text { Công nhân/Lao động } \\
\text { chân tay }\end{array}$ & $20(16,4)$ & & $30-49 \%$ & $48(39,3)$ \\
\hline & Đã nghỉ hưu & $78(63,9)$ & & $<30 \%$ & $46(37,7)$ \\
\hline & Thất nghiệp/Không việc làm & $18(14,8)$ & Tăng & Có & $34(27,9)$ \\
\hline & Khác & $2(1,6)$ & huyết áp & Không & $88(72,1)$ \\
\hline \multirow{6}{*}{$\begin{array}{l}\text { Trình } \\
\text { độ } \\
\text { hợc } \\
\text { vần }\end{array}$} & Không đi học & $15(12,3)$ & Tiểu & Có & $2(1,6)$ \\
\hline & Tiếu học & $60(49,2)$ & & Không & $120(98,4)$ \\
\hline & Tốt nghiệp THCS & $32(26,2)$ & \multirow{4}{*}{$\begin{array}{l}\text { Số bệnh } \\
\text { kèm }\end{array}$} & 0 bệnh kèm & $29(23,8)$ \\
\hline & Tốt nghiệp THPT & $10(8,2)$ & & 1 bệnh kèm & $27(22,1)$ \\
\hline & Đại học & $4(3,3)$ & & 2 bệnh kèm & $27(22,1)$ \\
\hline & Sau đại học & $1(0,8)$ & & 3 bệnh kèm & $26(21,3)$ \\
\hline \multirow{2}{*}{\multicolumn{2}{|c|}{$\begin{array}{c}\text { Đặc điếm } \\
\text { Tuối }\end{array}$}} & \multicolumn{2}{|c|}{ GTTB \pm ĐLC } & \multicolumn{2}{|c|}{ GTNN-GTLN } \\
\hline & & \multirow{2}{*}{\multicolumn{2}{|c|}{$\begin{array}{c}67,54 \pm 9,14 \\
278581967 \pm 280993451\end{array}$}} & \multicolumn{2}{|c|}{$50-99$} \\
\hline \multirow{2}{*}{\multicolumn{2}{|c|}{ Thu nhập trung bình tháng (VNĐ) }} & \multirow{2}{*}{\multicolumn{2}{|c|}{$\frac{2.785 .819,67 \pm 2.809 .934,51}{0,35 \pm 0,99}$}} & \multirow{2}{*}{\multicolumn{2}{|c|}{$0-13.000 .000$}} \\
\hline 8 & & & & & \\
\hline
\end{tabular}

Ghi chú: GTTB: giá trị trung bình; ĐLC: độ lệch chuấn; GTLN: giá trị lớn nhất; GTNN: giá trị nhỏ nhất.

Theo bảng 1, nghiên cứu ghi nhận mẫu ngoại trú có tỷ lệ nam nữ là 14,25:1 với tuổi thọ trung bình 67,54 \pm 9,14 tuổi và dao động từ 50-99 tuổi. Về mức hưởng bảo hiểm y tế, $77,90 \%$ mẫu nghiên cứu có mức hưởng $80 \%$ và chiếm đa số. Phần lớn người bệnh có trình độ tiểu học với tỷ lệ 49,20\%; tiếp theo là trình độ THCS (26,20\%) và có đến $12,30 \%$ không đi học. Về nghề nghiệp, người bệnh đã nghỉ hưu chiếm đa số với tỳ lệ $63,90 \%$; tiếp theo là nhóm người bệnh công nhân/lao động chân tay và thất nghiệp với tỷ lệ lần lượt là $16,40 \%$ và $14,80 \%$. Phần lớn người bệnh trong mẫu ngoại trú thuộc nhóm bệnh GOLD D (47,50\%), tiếp theo là người bệnh thuộc nhóm $G O L D B$ và $C$ với tỷ lệ lần lượt là $21,30 \%$ và $18,00 \%$; người bệnh nhóm GOLD $A$ có tỷ lệ thấp nhất (13,10\%). Đa số người bệnh có chỉ số $\mathrm{FEV}_{1}$ từ 30 - 49\% với $39,30 \%$; có $4,10 \%$ có có chỉ số $\mathrm{FEV}_{1} \geq 80 \%$ và chiếm tỷ lệ thấp nhất. Về bệnh kèm theo, 27,90\% mắc tăng huyết áp và $1,60 \%$ mắc bệnh tiểu đường; 23,80\% không có bệnh kèm. Số đợt nhập viện trung bình trong 12 tháng của người bệnh có giá trị $0,35 \pm 0,99$ và dao động từ $0-6$ đợt. Thu nhập trung bình của mẫu nghiên cứu có giá trị 2.785.819,67 $\pm 2.809 .934,51$ đồng và dao động từ 0 đến 13 triệu đồng.

Mẫu nghiển cứu nội trú. Khảo sát mẫu nghiên cứu gồm 30 người bệnh COPD điều trị nội trú tại bệnh viện Quận 11 , nghiên cứu ghi nhận đặc điểm mẫu nghiên cứu trình bày trong bảng 2 .

Bảng 2. Đặc điểm mẫu nghiên cứu nội trú

\begin{tabular}{|c|c|c|c|c|c|}
\hline \multicolumn{2}{|c|}{ Đặc điếm } & Tân số (\%) & \multicolumn{2}{|c|}{ Đặc điếm } & Tân số (\%) \\
\hline \multirow{2}{*}{$\begin{array}{l}\text { Giới } \\
\text { tính }\end{array}$} & Nữ & $3(10,0)$ & \multirow{4}{*}{$\begin{array}{l}\text { Giai đoạn } \\
\text { bệnh }\end{array}$} & GOLD A & $3(10,0)$ \\
\hline & Nam & $27(90,0)$ & & GOLD B & $7(23,3)$ \\
\hline \multirow{3}{*}{ BHYT } & $80 \%$ & $23(76,7)$ & & GOLD C & $7(23,3)$ \\
\hline & $95 \%$ & $3(10,0)$ & & GOLD D & $13(43,3)$ \\
\hline & $100 \%$ & $4(13,3)$ & \multirow{3}{*}{$\begin{array}{l}\text { Chỉ số } \\
\text { FEV1 }\end{array}$} & & \\
\hline \multirow{2}{*}{$\begin{array}{c}\text { Nghề } \\
\text { nghiệp }\end{array}$} & Buôn bán/Tự kinh & $2(6,7)$ & & $50-79 \%$ & $2(6,7)$ \\
\hline & Công nhân/Lao & $1(3,3)$ & & $30-49 \%$ & $12(40,0)$ \\
\hline
\end{tabular}




\begin{tabular}{|c|c|c|c|c|c|}
\hline & động chân tay & & & & \\
\hline & Đã nghỉ hưu & $22(73,3)$ & & $<30 \%$ & $16(53,3)$ \\
\hline & $\begin{array}{l}\text { Thất nghiệp /Không } \\
\text { viêc làm }\end{array}$ & $4(13,4)$ & \multirow{2}{*}{$\begin{array}{l}\text { Tăng } \\
\text { huyết áp }\end{array}$} & Có & $8(26,7)$ \\
\hline & Khác & $1(3,3)$ & & Không & $22(73,3)$ \\
\hline \multirow{7}{*}{$\begin{array}{l}\text { Trình } \\
\text { độ } \\
\text { hộc } \\
\text { vẩn }\end{array}$} & Không đi học & $2(6,7)$ & \multirow{2}{*}{$\begin{array}{l}\text { Tiểu } \\
\text { đường }\end{array}$} & Có & $1(3,3)$ \\
\hline & Tiếu học & $16(53,3)$ & & Không & $29(96,7)$ \\
\hline & Tốt nghiệp THCS & $7(23,3)$ & \multirow{5}{*}{$\begin{array}{l}\text { Số bệnh } \\
\text { kèm }\end{array}$} & 0 bệnh kèm & $6(20,0)$ \\
\hline & Tốt nghiệp THPT & $2(6,7)$ & & 1 bệnh kèm & $8(26,7)$ \\
\hline & Đại học & $2(6,7)$ & & 2 bệnh kèm & $7(23,3)$ \\
\hline & \multirow{2}{*}{ Sau đại học } & \multirow{2}{*}{$1(3,3)$} & & 3 bệnh kèm & $6(20,0)$ \\
\hline & & & & $>4$ bệnh kèm & $3(10,0)$ \\
\hline \multicolumn{2}{|r|}{ Đặc điếm } & \multicolumn{2}{|c|}{ GTTB \pm ĐLC } & \multicolumn{2}{|c|}{ GTNN-GTLN } \\
\hline & Tuối & \multicolumn{2}{|c|}{$66,40 \pm 9,58$} & \multicolumn{2}{|c|}{$51-90$} \\
\hline \multicolumn{2}{|c|}{$\begin{array}{l}\text { Thu nhập trung bình tháng } \\
\text { (VNĐ) }\end{array}$} & \multicolumn{2}{|c|}{$3.227 .666,67 \pm 2.143 .490,04$} & \multicolumn{2}{|c|}{$150.000-8.000 .000$} \\
\hline \multirow{2}{*}{\multicolumn{2}{|c|}{$\begin{array}{l}\text { Thời gian nằm viện (ngày) } \\
\text { Số đơt nhâp viên } 12 \text { tháng }\end{array}$}} & \multirow{2}{*}{\multicolumn{2}{|c|}{$\frac{10,60 \pm 8,33}{1,22 \pm 0,61}$}} & \multicolumn{2}{|c|}{$4-45$} \\
\hline & & & & \multicolumn{2}{|c|}{$0-2$} \\
\hline
\end{tabular}

Ghi chú: GTTB: giá trị trung bình; ĐLC: độ lệch chuấn; GTLN: giá trị lớn nhất; GTNN: giá trị nhỏ nhất

Theo bảng 2, nghiên cứu ghi nhận mẫu nội trú có tỷ lệ nam nữ là 9:1 với tuổi thọ trung bình $66,40 \pm 9,58$ tuổi và dao động từ 51-90 tuổi. Về mức hưởng bảo hiểm y tế $76,70 \%$ người bệnh có mức hưởng $80 \%$ và chiếm đa số. Hơn phân nửa người bệnh có trình độ tiểu học với tỷ lệ $53,30 \%$; tiếp theo là trình độ $\mathrm{THCS}(23,30 \%)$ và trình độ sau đại học chiếm tỷ lệ thấp nhất là 3,30\%. Về nghề nghiệp, người bệnh đã nghỉ hưu chiếm đa số với tỷ lệ $73,30 \%$; tiếp theo là nhóm người bệnh buôn bán/tự kinh doanh, nội trợ và thất nghiệp/không có việc làm với tỷ lệ bằng nhau $(6,70 \%)$. Phần lớn người bệnh trong mẫu ngoại trú thuộc nhóm bệnh GOLD D với 43,30\%, tiếp theo là nhóm GOLD $B$ và $C$ chiếm tỷ lệ bằng nhau $(23,30 \%)$; thấp nhất là nhóm GOLD $A$ với $10,00 \%$. Người bệnh có chỉ số $\mathrm{FEV}_{1}<30 \%$ chiếm đa số với $53,30 \%$. Về bệnh kèm theo, có
$26,70 \%$ mắc tăng huyết áp và 3,30\% mắc bệnh tiểu đường và có $20,00 \%$ không có bệnh kèm. Thu nhập trung bình 3.227.666,67 \pm $2.143 .490,04$ đồng và dao động từ 150.000 đến 8.000 .000 .000 đồng. Thời gian nằm viện trung bình $10,60 \pm 8,33$ ngày và dao động từ 4-45 ngày điều trị. Số đợt nhập viện trung bình trong 12 tháng của người bệnh có giá trị 1,22 $\pm 0,61$ và dao động từ $0-2$ đợt.

Chi phí điêuu trị bệnh phổi tắc nghẽn mạn tính trong 1 tháng

Khảo sát chi phí điều trị COPD trên mẫu nghiên cứu gồm 122 người bệnh ngoại trú và 30 người bệnh nội trú COPD điều trị tại Bệnh viện Quận 11 từ tháng 2 đến tháng $5 / 2021$ và tần suất khám nội trú/ngoại trú tại bệnh viện giai đoạn từ tháng 1 đến hết tháng 12/2020, đề tài ghi nhận kết quả trình bày trong bảng 3 .

Bảng 3. Tống chi phí điều trị COPD mỗi tháng theo từng giai đoạn bệnh

\begin{tabular}{|c|c|c|c|c|c|c|}
\hline $\begin{array}{c}\text { Giai } \\
\text { đoạn }\end{array}$ & $\begin{array}{l}\text { Thành } \\
\text { phân chi } \\
\text { phí }\end{array}$ & $\begin{array}{l}\text { Chi phí } 1 \\
\text { đợt ngoại } \\
\text { trú }\end{array}$ & $\begin{array}{c}\text { Số đợt } \\
\text { ngoại } \\
\text { trú / tháng }\end{array}$ & $\begin{array}{l}\text { Chi phí } 1 \\
\text { đợt nội trú }\end{array}$ & $\begin{array}{c}\text { Số đợt } \\
\text { nội } \\
\text { trú / tháng }\end{array}$ & $\begin{array}{l}\text { Chi phí điều } \\
\text { trị } 1 \text { tháng }\end{array}$ \\
\hline \multirow{4}{*}{$\underset{\text { A }}{\text { GOLD }}$} & CPTTYT & $515.436,56$ & \multirow{4}{*}{0,081} & $2.998 .033,99$ & \multirow{4}{*}{0,011} & $74.728,74$ \\
\hline & CPTTNYT & $23.453,35$ & & 0,00 & & $1.899,72$ \\
\hline & CPGT & $22.836,54$ & & 0,00 & & $1.849,76$ \\
\hline & TÖNG & $561.726,45$ & & $2.998 .033,99$ & & $78.478,22$ \\
\hline \multirow{4}{*}{$\underset{\text { B }}{\text { GOLD }}$} & CPTTYT & $477.760,37$ & \multirow{4}{*}{0,126} & $4.593 .607,07$ & \multirow{4}{*}{0,022} & $161.257,16$ \\
\hline & CPTTNYT & $29.678,30$ & & $504.685,19$ & & $14.842,54$ \\
\hline & CPGT & $51.849,11$ & & $1.439 .560,44$ & & $38.203,32$ \\
\hline & TỐNG & $559.287,78$ & & $6.537 .852,70$ & & $214.303,02$ \\
\hline \multirow{4}{*}{$\underset{\text { C }}{\text { GOLD }}$} & CPTTYT & $573.799,89$ & \multirow{4}{*}{0,109} & $5.544 .390,01$ & \multirow{4}{*}{0,025} & $201.153,94$ \\
\hline & CPTTNYT & $29.460,82$ & & $664.613,84$ & & $19.826,58$ \\
\hline & CPGT & $48.951,05$ & & $1.664 .835,17$ & & $46.956,54$ \\
\hline & TÓNG & $652.211,76$ & & $7.873 .839,02$ & & $267.937,06$ \\
\hline
\end{tabular}




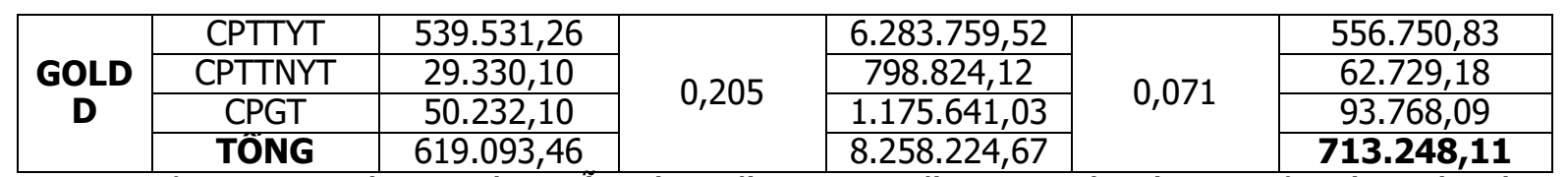

Theo bảng 3, chi phí trung bình mối tháng điều trị tăng dần theo mức độ nặng của bệnh với giá trị lần lượt là 78.478,22; 214.303,02; 267.937,06; 713.248,11 đồng cho các giai đoạn bệnh từ GOLD A đến GOLD D. Chi phí điều trị cho người bệnh ở giai đoạn GOLD D gấp 9,09 lần giai đoạn GOLD A. Điều này được giải thích bởi GOLD $D$ là giai đoạn nặng nhất, người bệnh cần phải sử dụng nhiều thuốc phối hợp cũng như tần suất nhập viện cao hơon so với các giai đoạn còn lại.

Phân tích cấu trúc chi phí trung bình mỗi tháng điều trị COPD, đề tài ghi nhận kết quả được trình bày trong hình 1.

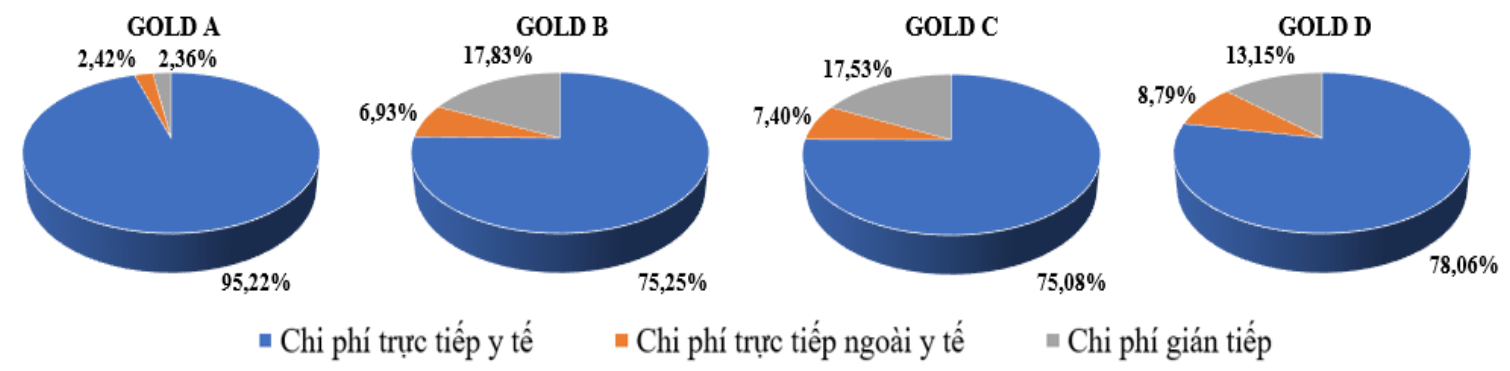

Hình 1. Cấu trúc chi phí điều trị bệnh phổi tắc nghẽn mạn tính theo giai đoạn bệnh

Theo hình 1, đề tài ghi nhận cấu trúc chi phí trung bình mỗi tháng điều trị bệnh phổi tắc nghẽn mạn tính tương đương ở cả 4 giai đoạn bệnh từ GOLD A đến GOLD D. Cụ thể, CPTTYT chiếm tỷ lệ cao nhất ở cả 4 giai đoạn bệnh và cao nhất ở GOLD A với 95,22\%, GOLD B - 75,25\%, GOLD C $75,08 \%$ và GOLD D - 78,06\%. Tiếp theo là CPGT với tỷ lệ dao động từ 2,36\% đến $17,83 \%$ và thấp nhất là CPTTNYT với tỷ lệ dao động từ 2,42\% đến 8,79\% ở 4 giai đoạn bệnh.

\section{BÀN LUÂNN}

Nghiên cứu được thực hiện tại Bệnh viện Quận 11. Tỷ lệ người bệnh ngoại trú và nội trú là 4:1. Trong đó, mẫu ngoại trú có tỷ lệ nam:nữ là $14,25: 1$ thấp hơn so với nghiên cứu dịch tễ của Namhee Kwon và cộng sự [6]. Tỷ lệ người bệnh đã nghỉ hưu chiếm đa số với độ tuổi trung bình là 67,54 tuổi cao hơn so với nghiên cứu của tác giả Nguyễn Thanh Hà và cộng sự [7] thực hiện tại bệnh viện Phổi Trung ương Hà Nội năm 2017. Với mẫu nội trú, tỷ lệ nam:nữ là $9: 1$, tương đương với nghiên cứu của Ngô Quý Châu và cô̂ng sự [8] về số người bệnh nội trú COPD tại Hà Nội năm 2018, tuy nhiên, độ tuổi trung bình của mẫu nội trú trong nghiên cứu thấp hỡn nghiên cứu này. Thu nhập trung bình ở cả 2 mẫu ngoại trú và nội trú trong nghiên cứu đều thấp hơn so với thu nhập bình quân đầu người mối tháng được công bố bởi Tổng Cục Thống kê quý IV năm 2020 (4.190.000 VNĐ) [9].

Nghiên cứu cho thấy chi phí điều trị trung bình mối tháng tăng theo mức độ nặng của bênh và cao nhất ở nhóm GOLD $D$, do đó việc kiểm soát diễn tiến của bệnh là rất quan trọng nhằm giúp giảm gánh nặng kinh tế của bệnh. Bên cạnh đó, trong cấu trúc chi phí, nghiên cứu cho thây chi phí trực tiếp y tế chiếm tỷ lệ cao nhất và trên $75 \%$ ở cả 4 giai đoạn bệnh, tỷ lệ này cao hơn so với nghiên cứu của Hilleman và cộng sự tại $\mathrm{Ba}$ Lan năm 2000 [5]. Vì vậy, giảm thiểu chi phí trực tiếp y tế bằng nhiều biện pháp có thể giúp giảm đáng kể gánh nặng kinh tế của bệnh.

\section{KẾT LUÂ̂N}

Khảo sát người bệnh điều trị COPD tại Bệnh viện Quận 11, nghiên cứu ghi nhận tổng chi phí điều trị trung bình mỗi tháng của người bệnh tăng dần theo mức độ nặng của bệnh với chi phí điều trị nhóm GOLD D là lớn nhất và chi phí trực tiếp y tế chiếm ưu thế. Vì vậy, nâng cao ý thức của người bệnh trong phát hiện sớm và tuân thủ điều trị giúp giảm tỷ lệ tiến triển bệnh nặng hơn có thể làm giảm đáng kể chi phí trực tiếp y tế đồng thời giảm gánh nặng kinh tế của bệnh.

\section{TÀI LIÊU THAM KHẢO}

1. World Health Organization (2015), "Chronic respiratory diseases, burden of chronic obstructive pulmonary disease", http://wwwwhoint/ respiratory/copd/burden/en/. Ngày truy cập: 20/10/2020.

2. Pauwels R. et al. (2004), "COPD exacerbations: 
the importance of a standard definition", Respiratory medicine. 98 (2), pp. 99-107.

3. GOLD (2011) From the global strategy for the diagnosis, management and prevention of COPD. Global Initiative for Chronic Obstructive Lung Disease. Available from: http://www.goldcopd.org. Ngày truy cập: 20/05/2021.

4. Mannino D. M. (2003), "Chronic obstructive pulmonary disease: definition and epidemiology", Respiratory care. 48 (12), pp. 1185-1193.

5. Hilleman D. E. et al. (2000), "Pharmacoeconomic evaluation of COPD", Chest. 118 (5), pp. 1278-1285.

6. Kwon N. et al. (2013), "Validity of the COPD assessment test translated into local languages for Asian patients", Chest. 143 (3), pp. 703-710.

7. Nguyen H. T. et al. (2019), "Nutritional status, dietary intake, and health-related quality of life in outpatients with COPD", International journal of chronic obstructive pulmonary disease. 14, pp. 215.

8. Ngo C. Q. et al. (2019), "Inhaler technique and adherence to inhaled medications among patients with acute exacerbation of chronic obstructive pulmonary disease in Vietnam", International journal of environmental research and public health. 16 (2), pp. 185.

9. Tổng quan kinh tế - xã hội Việt Nam năm 2020 , Tổng cục Thống kê.

\section{ĐÁNH GIÁ HIÊU QUẢ CỦA NEP Cổ TAY TRONG ĐÎ̀UU TRI HỐ TRỢ HộI CHỨNG ỐNG CỔ TAY}

\section{TÓM TẮT}

Hội chứng ống cổ tay là bệnh lý thần kinh ngoại biên phổ biến, có nhiều phưởng pháp điều trị khác nhau trong đó đeo nep cổ tay là một phương pháp hỗ trợ hữu hiệu trong điều trị hội chứng ống cố tay. Mục tiều: Đánh giá hiệu quả của nẹp cổ tay trong điều trị hố trợ hội chứng ổng cổ tay và xác định một số yếu tổ liên quan đến kết quả điêu trị. Đối tượng và phương pháp nghiên cứu: Nghiền cứu thử nghiệm lâm sàng có đối chứng theo dõi trong 2 tháng trên 63 bênh nhân hôi chứng ống cổ tay chia làm 2 nhóm: 32 bểnh nhân được dùng 1 loai thuốc NSAIDs trong 2 tuân kết hợp với đeo nẹp cổ tay trong 2 tháng, 31 bệnh nhân được dùng với duy nhất 1 loại thuốc NSAIDs trong 2 tuần. Kết quả: Sau 2 tháng điêuu trị, có sự cải thiện điểm VAS, điểm Boston triệu chứng và chức năng, tốc độ dẫn truyền thần kinh giữa và diện tích thần kinh giữa ở nhóm dùng NSAIDs và nẹp cổ tay: VAS trung bình giảm từ 2,0 xuống 0,4 điểm, Boston triệu chứng giảm từ 16,7 xuống 12,7 điểm, Boston chức năng giảm từ 11,4 xuống 8,7 điểm, tốc đô dẫn truyền cảm giác thần kinh giữa có cải thiện tăng từ 41,7 lên 45,8 (m/s), diện tích ngang thần kinh giữa có giảm từ 11.7 xuống $9.8\left(\mathrm{~mm}^{2}\right)$, cao hơn nhóm chứng $(p<0,05)$. Một số yếu tố liên quan đến kết quả điều tri: Tuối và BMİ có tương quan nghịch với sự thay đổi điểm VAS; thay đổi điểm Boston triệu chứng và chức năng. Kết luận: Nẹp cổ tay là phương pháp điều trị hỗ trợ có hiệu quả trong điêu trị hội chứng ống cổ tay.

Tư khóa: Nẹp cổ tay, Hội chứng ống cổ tay.

\footnotetext{
${ }^{1}$ Dại học Y Hà Nội

${ }^{2}$ Bềnh viện Bạch Mai

Chịu trách nhiệm chính: Trần Thị Tô Châu

Email: tranthitochau72@yahoo.com.au

Ngày nhận bài: 21.6.2021

Ngày phản biên khoa họ: 16.8.2021

Ngày duyệt bài: 23.8.2021
}

\section{Hà Thị Kim Khuyên ${ }^{1}$, Trần Thị Tô Châu ${ }^{2}$ \\ SUMMARY \\ EVALUATING THE EFFICACY OF SUPPORTIVE THERAPY OF SHORT WRIST SPLINT IN PATIENTS WITH CARPAL TUNNEL SYNDROME}

Carpal tunnel syndrome is the most common peripheral nerve entrapment syndrome worldwide 1 . There are availability of several therapies ranges from non-surgical to surgical management1. Short wrist splints is one of the most typically employed therapeutic procedures. Objectives: To evaluate the efficacies of supportive therapy of short wrist splint in patients with carpal tunnel syndrome under NSAIDs treatment and determind the factors interfering the treatment results. Methods: Controlled clinical trial were followed up to 2 months in 63 patients with carpal tunnel syndrome, divided into two groups: 32 patients received NSAIDs for 2 weeks and a standard wrist splint in neutral position to be worn at night, if possible, during the day, 31 patients were treated solely with NSAIDs for 2 weeks. Results: After 2 months of treatment, there were an improvement in VAS, Boston scores, Distal median motor latencies (DMLm) and median sensory conduction velocities (SCVm) in the research group: The average VAS were decreased from 2.0 to 0.4 points, Boston symptom scores were declined from 16.7 to 12.7 points, Boston functional scores were declined from 11.4 to 8.7 points, median sensory conduction velocities $(\mathrm{SCVm})$ were improved considerable from 41.7 to $45.8 \mathrm{~m} / \mathrm{s}$, the cross-sectional area of the median nerve (CSA) were fell from 11.7 to $9.8 \mathrm{~mm}^{2}$, higher than the placebo group $(p<0,05)$. The factors interfering the treatment results: Age and BMI negatively correlated with the change in VAS scores, Boston symptoms and function scores. Conclusion: A short wrist splint is effective therapy support in patients with carpal tunnel syndrome.

Key words: wrist splint, carpal tunnel syndrome.

I. ĐĂTT VẤN ĐỀ

Hội chứng ống cổ tay (HCOCT) là bệnh lý 
thần kinh ngoai biên thường găp, nhất là ở phụ nữ trên 40 tuổi. Bệnh do nhiều nguyên nhân khác nhau trong đó nguyên nhân nghề nghiệp thường gặp, thường xảy ra khi làm việc bằng tay liên tục duy trì ở một tư thế cố định trong một thời gian dài. Về cơ chế bệnh sinh của bệnh, thần kinh giữa đi chung với những gân cơ gấp của các ngón tay trong ống cổ tay là một cấu trúc không co giãn được nên khi có lực nén ép kéo dài gây viêm gân gấp chung các ngón tay sẽ tạo một lực chèn ép thần kinh giữa dẫn tới sự tắng áp lực quanh dây thần kinh giữa trong đoạn ống cổ tay gây rối loạn dẫn truyền sợi trục, làm suy giảm chức năng dây thần kinh tạo nên các bi u hiện lâm sàng như tê, đau, rối loạn cảm giác. Sự chèn ép kéo dài dẫn tới sự thay đởi vĩnh viễn, phá hủy cấu trúc thần kinh, thay bằng mô xơ seo dày đặc. Chẩn đoán chủ yếu dựa vào các triệu chứng lâm sàng.

Có nhiều phương pháp điều tri về nôi khoa và ngoại khoa. Các biện pháp dùng thuốc chống viêm không steroid, corticoid có hiệu quả nhanh chóng nhưng gây nhiều biến chứng như viêm loét dạ dày hành tá tràng, xuất huyết tiêu hóa, nhiễm trùng... Gần đây trên thế giới có nhiều nghiên cứu đánh giá hiệu quả của nẹp cổ tay trong điều trị hội chứng ống cổ tay và cho kết quả tốt, đồng thời ít tác dụng không mong muốn, và giá thành không quá đắt. Tuy nhiên, ở Việt Nam chưa có nghiên cứu nào nghiên cứu một cách hệ thống về sử dụng nẹp cổ tay trong hồi chứng ống cổ tay. Chính vì vậy, chúng tôi tiến hành nghiên cứu đề tài này với 2 mục tiêu:

1. Đánh giá hiệu quả của nẹp cổ tay trong điều trị hố trợ của hội chứng ống cổ tay.

2. Xác định mốt số yêu tố liên quan đến kết quả điều trị.

\section{II. ĐỐI TƯợNG VÀ PHƯƠNG PHÁP NGHIÊN CỨU}

\section{1. Đối tượng nghiên cứu}

Đia điểm nghiên cứu: Bênh viện Bach Mai và bệnh viện Đại học Y Hà Nội.

Đối tượng nghiên cứu gồm 63 bệnh nhân được chẩn đoán Hội chứng ống cổ tay theo tiêu chuẩn sau:

+ Có ít nhất 1 dấu hiệu lâm sàng: tê, đau ngón $1,2,3$ và nửa ngoài ngón 4 ; tê đau tăng lên khi cử động lặp lại liên tục bàn tay; tê đau bàn tay tăng về đêm; các nghiệm pháp Tinel, Phalen, Durkan dương tính.

+ Và có ít nhất một dấu hiệu bất thường trên chẩn đoán điện theo hiệp hội thần kinh học Hoa Kỳ: kéo dài thời gian tiềm vận động $D M L>4,2 \mathrm{~ms}$ hoặc giảm tốc độ dẫn truyền cảm giác $S C V<50 \mathrm{~m} / \mathrm{s}$.
Bệnh nhân đồng ý tham gia nghiên cứu, tuổi trên 16. Không có các tổn thương khác chèn ép thần kinh giữa như trong các bệnh: viêm màng hoạt dịch hoạt trong viêm khớp dạng thấp, hạt tophi, kén hoạt dịch, các khối u vùng cố tay, chân thương vùng cổ tay, di chứng gãy xương sau chấn thương, nhiễm trùng, phụ nữ có thai... Không có tiền sử điều trị HCOCT: tiêm steroid, phẫu thuật.

2.2. Phương pháp nghiên cứu. Thử nghiệm lâm sàng có nhóm chứng, theo dõi dọc.

Nhóm can thiệp gồm 32 bênh nhân được điều trị bằng dùng 1 loại thuốc NSAIDs (Meloxicam (Mobic): 7,5-15mg/ngày, hoăc Celecoxib (Celebrex): $200 \mathrm{mg} / \mathrm{ngày}$ hoặc Etoricoxib (Arcoxia): $60-90 \mathrm{mg} /$ ngày) trong 2 tuần kết hợp với đeo nep cổ tay vào ban đêm hoặc cả ngày nếu có thể trong 2 tháng. Nhóm chứng gồm 31 bệnh nhân được dùng với duy nhất 1 loại thuốc NSAIDs (Meloxicam (Mobic): 7,5- 15 mg/ ngày, hoặc Celecoxib (Celebrex): 200mg/ngày, Etoricoxib (Arcoxia): 60-90 mg/ngày) trong 2 tuân.

Nẹp cố tay sử dụng trong nghiên cứu là Nẹp cổ tay Orbe $\mathrm{H} 1$.

Đánh giá kết quả điều trị bệnh nhân dựa trên thang điểm đau VAS, thang điểm Boston tại các thời điểm trước điều trị (TO), sau điều trị 1 tháng (T1), sau điều trị 2 tháng (T2), đánh giá dựa trên đo điện dẫn truyền thần kinh và siêu âm thần kinh giữa tại thời điểm trước điều trị (T0) và sau điều trị 2 tháng (T2). Các yếu tố liên quan đến kết quả điều trị được ghi nhận tại tất cả các thời điểm nghiên cứu.

2.3. Thời gian nghiên cứu: từ tháng $7 / 2020$ đến tháng $7 / 2021$.

2.4. Xử lí số liệu: Phần mềm IBM SPSS Statistics 20

\section{KẾT QUẢ NGHIÊN CỨU}

\section{1. Đặc điểm chung của bệnh nhân} nghiên cứu

\begin{tabular}{|c|c|c|c|}
\hline $\begin{array}{c}\text { Các } \\
\text { thông } \\
\text { số }\end{array}$ & $\begin{array}{c}\text { NSAIDs } \\
(\mathbf{n = 3 1 )}\end{array}$ & $\begin{array}{c}\text { NSAIDs+Nep } \\
(\mathbf{n = 3 2 )}\end{array}$ & $\mathbf{p}$ \\
\hline Tuối & $49,7 \pm 11,1$ & $49,6 \pm 11,1$ & $\mathrm{p}>0,05$ \\
\hline Nam & $9,7 \%$ & $6,3 \%$ & $\mathrm{p}>0,05$ \\
\hline Nữ & $90,3 \%$ & $93,8 \%$ & $\mathrm{p}>0,05$ \\
\hline BMI & $21,8 \pm 1,6$ & $21,3 \pm 1,4$ & $\mathrm{P}>0,05$ \\
\hline $\begin{array}{c}\text { Thời gian } \\
\text { đau }\end{array}$ & $8,5 \pm 7,9$ & $7,5 \pm 5,5$ & $\mathrm{p}>0,05$ \\
\hline VAS & $3,0 \pm 2,0$ & $2,0 \pm 1,9$ & $\mathrm{p}>0,05$ \\
\hline
\end{tabular}

Nhận xét: Không có sự khác biệt về tuối, giới, BMI, VAS, thời gian đau giữa 2 nhóm nghiên cứu $(p>0,05)$. 
3.2. Đánh giá kết quả điêu trị nẹp cổ tay trong hội chứng ống cổ tay

3.2.1. Đánh giá mức độ cải thiện độ đau theo thang điểm VAS

Bảng 3.1: Thay đổi điểm VAS sau 2 tháng điều trị

\begin{tabular}{|c|c|c|c|c|}
\hline & T0 (0) & T1(1) & T2(2) & P \\
\hline NSAIDs ( $\mathrm{n}=31)$ & $3.0 \pm 2.0$ & $1.75 \pm 1.3$ & $0.9 \pm 1.2$ & $\mathrm{P}_{02}=0.000$ \\
\hline NSAIDs+Splint ( $\mathrm{n}=32)$ & $2.0 \pm 1.9$ & $1.2 \pm 1.3$ & $0.4 \pm 0.8$ & $\mathrm{P}_{02}=0.000$ \\
\hline p & 0.056 & 0.103 & 0.048 & \\
\hline
\end{tabular}

Nhận xét: Cả 2 nhóm BN đều có sự cải thiện thời điểm T2 thì nhóm NSAIDs và nẹp cố tay có thang điểm VAS so với trước điều trị $(p<0,05)$. sự cải thiện điểm VAS tốt hơn so với nhóm Tại thời điểm bắt đầu điều trị và sau điều trị 1 NSAIDs $(p<0,05)$. Điểm VAS của nhóm can thiệp tháng, không có sự khác biệt giữa 2 nhóm điêuu từ $2,0 \pm 1,9$ tại thời điểm T0 giảm xuống $1,2 \pm 1,3$ trị về cải thiện thang điểm VAS $(p>0,05)$. Tại tại $T 1$ và $0,4 \pm 0,8$ tại T2.

3.2.2. Đánh giá mức độ cải thiện dựa trên thang điểm Boston

Bảng 3.2: Thay đổi điểm Boston sau 2 tháng điều trị

\begin{tabular}{|c|c|c|c|c|c|c|}
\hline & \multicolumn{3}{|c|}{$\begin{array}{c}\text { Cải thiện điểm } \\
\text { Boston triệu chứng }\end{array}$} & \multicolumn{3}{c|}{$\begin{array}{c}\text { Cải thiện điểm } \\
\text { Boston chức năng }\end{array}$} \\
\cline { 2 - 7 } & $\begin{array}{c}\text { NSAIDs } \\
(\mathbf{n = 3 1 )}\end{array}$ & $\begin{array}{c}\text { NSAIDs+ } \\
\text { Nẹp (n=32) }\end{array}$ & $\mathbf{P}$ & $\begin{array}{c}\text { NSAIDs } \\
(\mathbf{n = 3 1 )}\end{array}$ & $\begin{array}{c}\text { NSAIDs+ Nẹp } \\
(\mathbf{n = 3 2})\end{array}$ & $\mathbf{P}$ \\
\hline Trước(T0) & $16,5 \pm 1,7$ & $16,7 \pm 2,0$ & 0,626 & $11,3 \pm 1,2$ & $11,4 \pm 1,2$ & 0,709 \\
\hline Sau 1tháng (T1) & $15,1 \pm 2,0$ & $14,9 \pm 2,1$ & 0,760 & $9,9 \pm 1,2$ & $9,8 \pm 1,3$ & 0,928 \\
\hline Sau 2 tháng(T2) & $13,9 \pm 1,8$ & $12,7 \pm 1,8$ & 0,010 & $9,5 \pm 1,0$ & $8,7 \pm 1,0$ & 0,002 \\
\hline
\end{tabular}

Nhận xét: Cả 2 nhóm BN đều có sự cải thiện tốt hơn so với nhóm chứng, sự khác biệt có ý về điểm Boston triệu chứng và điểm Boston chức nghĩa thống kê với $p<0,05$. Điểm Boston triệu năng so với trước điều trị với $p<0,05$. Tại thời chứng của nhóm can thiệp từ $16,7 \pm 2,0$ tại thời điểm 1 tháng, không có sự khác biệt giữa 2 điểm T0 giảm xuống 14,9 $\pm 2,1$ tại T1; $12,7 \pm 1,8$ nhóm điều trị về sự cải thiện điểm Boston triệu tại T2. Điểm Boston chức năng của nhóm can chứng và chức năng $(\mathrm{p}>0,05)$. ). Tại thời điểm thiệp từ $11,4 \pm 1,2$ tại thời điểm T0 giảm xuống T2 nhóm NSAIDs và nẹp cổ tay có sự cải thiện $9,8 \pm 1,3$ tại T1; $8,7 \pm 1,0$ tại T2.

3.2.3. Đánh giá mức độ cải thiện dựa trên tốc độ dẫn truyên thân kinh giữa Bảng 3.3: Thay đổi tốc độ dẫn truyèn thän kinh giữa sau 2 tháng điều trị

\begin{tabular}{|c|c|c|c|c|}
\hline & Thời gian & NSAIDs & NSAIDs+ Nẹp cố tay & P \\
\hline \multirow{2}{*}{ DMLm(ms) } & Trước(T0) & $4,5 \pm 0,9$ & $4,9 \pm 0,8$ & 0,142 \\
\cline { 2 - 5 } & Sau 2 tháng(T2) & $4,3 \pm 0,8$ & $4,5 \pm 0,7$ & 0,170 \\
\hline \multirow{3}{*}{$\mathbf{S C V m}(\mathbf{m} / \mathbf{s})$} & $P$ & 0.000 & 0.000 & \\
\hline & Trước(T0) & $41,7 \pm 5,8$ & $42,7 \pm 4,8$ & 0,481 \\
\cline { 2 - 5 } & Sau 2 tháng(T2) & $45,8 \pm 6,4$ & $49,5 \pm 4,8$ & 0,011 \\
\hline & $P$ & 0.000 & 0.000 & \\
\hline
\end{tabular}

DMLm: Thời gian tiềm vận động của thần của thần kinh giữa tốt hơn so với nhóm chứng, kinh giữa

SCVm: Tốc độ dẫn truyền cảm giác của thần kinh giữa

Nhận xét: Sau 2 tháng điều trị, không có sự khác biệt giữa 2 nhóm điều trị về sự cải thiện thời gian tiềm vận động của thần kinh giữa $(p>0,05)$. Tuy nhiên, nhóm NSAIDs và nẹp cổ tay có sự cải thiện về tốc độ dẫn truyền cảm giác

sự cải thiện có ý nghĩa thống kê với $p<0,05$. Tốc độ dẫn truyền cảm giác của thần kinh giữa của nhóm can thiệp từ $42,7 \pm 4,8$ tại thời điểm T0 tăng lên $49,5 \pm 4,8$ tại thời điểm $T 2$.

3.2.4. Đánh giá mức độ cải thiện diện tích thân kinh giữa (cắt ngang mức xương đậu) dựa trên siêu âm cổ tay

Bảng 3.4: Thay đổi diện tích thần kinh giữa sau 2 tháng điều trị

\begin{tabular}{|c|c|c|c|}
\hline Thời gian & NSAIDs & NSAIDs+ Nẹp cố tay & P \\
\hline Trước (T0) & $11,7 \pm 1,8$ & $11,7 \pm 1,9$ & 0,973 \\
\hline Sau 2 tháng (T2) & $10,7 \pm 1,9$ & $9,8 \pm 1,2$ & 0,044 \\
\hline P & 0.000 & 0.000 & \\
\hline
\end{tabular}

Nhận xét: Cả 2 nhóm BN đều có sự cải thiện về diện tích thần kinh giữa (cắt ngang xương đậu) 
so với trước điều trị với $p<0,05$. Sau điều trị 2 tháng nhóm NSAIDs và nẹp cổ tay có sự cải thiện diện tích thần kinh giữa tốt hơn so với nhóm chứng, sự cải thiện có ý nghĩa thống kê với $p<0,05$. Diện tích thần kinh giữa của nhóm can thiệp từ $11,7 \pm 1,9$ tại thời điểm T0 có giảm xuống 9,8 $\pm 1,2$ tại T2.

\subsection{Các yếu tố liên quan đến điêuu trị}

\section{Bảng 1.5. Các yếu tố liên quan đến điều trị}

\begin{tabular}{|c|c|c|c|c|c|c|c|}
\hline \multirow{2}{*}{$\begin{array}{c}\text { Yếu } \\
\text { tố }\end{array}$} & \multirow{2}{*}{ Nhóm } & \multicolumn{2}{c|}{$\begin{array}{c}\text { Tương quan với } \\
\text { thay đổi điểm VAS }\end{array}$} & \multicolumn{2}{c|}{$\begin{array}{c}\text { Tương quan với } \\
\text { thay đổi điểm } \\
\text { Boston triệu chứng }\end{array}$} & $\begin{array}{c}\text { Tương quan với } \\
\text { thay đổi điểm } \\
\text { Boston triệu chứng }\end{array}$ \\
\cline { 3 - 8 } & & $\mathbf{r}$ & $\mathbf{p}$ & $\mathbf{r}$ & $\mathbf{p}$ & $\mathbf{r}$ & $\mathbf{p}$ \\
\hline \multirow{2}{*}{ Tuổi } & NSAIDs & -0.864 & $\mathbf{0 . 0 0 1}$ & -0.943 & $\mathbf{0 . 0 0 0}$ & -0.897 & $\mathbf{0 . 0 0 3}$ \\
\cline { 2 - 8 } & NSAIDs+ nẹp & -0.916 & $\mathbf{0 . 0 0 2}$ & -0.879 & $\mathbf{0 . 0 0 3}$ & -0.947 & $\mathbf{0 . 0 0 2}$ \\
\hline \multirow{2}{*}{ BMI } & NSAIDs & -0.831 & $\mathbf{0 . 0 1}$ & -0.766 & $\mathbf{0 . 0 0 3}$ & -0.753 & $\mathbf{0 . 0 0 5}$ \\
\cline { 2 - 7 } & NSAIDS+ nẹp & -0.962 & $\mathbf{0 . 0 0 1}$ & -0.826 & $\mathbf{0 . 0 0 8}$ & -0.862 & $\mathbf{0 . 0 1}$ \\
\hline
\end{tabular}

Tuổi và BMI có tương quan nghịch với sự thay đổi điểm VAS; sự thay đổi điểm Boston triệu chứng và chức năng sau 2 tháng điều trị $(r<0, p<0,05)$ ở cả 2 nhóm bệnh nhân nghiên cứu.

\section{BÀN LUÂN}

4.1. Đặc điểm chung của đối tượng nghiên cứu.

- Nhóm bệnh nhân nghiên cứu chủ yếu nằm trong nhóm tuổi trung niên.

Tuổi trung bình của nhóm can thiệp là 49,6 \pm 11,1 . Chủ yếu là bệnh nhân nữ với tî̉ lệ $93,8 \%$ ở nhóm can thiệp. Thời gian đau trung bình của nhóm can thiệp là $7,5 \pm 5,5$. BMI trung bình của nhóm can thiệp là $21,3 \pm 1,4$. Không có sự khác biệt về tuổi, giới, BMI, VAS, thời gian đau giữa 2 nhóm nghiên cứu $(p>0,05)$.

4.2. Kết quả của phương pháp điêu trị hỗ trợ nẹp cổ tay trong HCOCT

4.2.1. Cải thiênn mức độ đau. Kết quả nghiên cứu cho thấy có sự cải thiện của thang điểm VAS ở cả 2 nhóm nghiên sau điều trị. Tại thời điểm T2, nhóm dùng nẹp cổ tay có tác dụng giảm đau tốt hơn so với nhóm chứng (Bảng 1.1, $\mathrm{p}<0.05)$. Như vậy nẹp cổ tay với cơ chế duy trì cho cổ tay ở tư thế trung gian, ngăn ngừa sự gập hoặc duỗi cổ tay kéo dài, làm giảm áp lực trong ổng cổ tay, giúp giảm tổn thương thẩn kinh giữa, có tác dụng giúp giảm đau.

4.2.1. Cải thiện triệu chứng và chức năng bàn tay. Triệu chứng và chức năng bàn tay do thần kinh giữa chi phối thể hiện qua thang điểm Boston, kết quả nghiên cứu cho thây cả 2 phương pháp đều cải thiện triệu chứng và chức năng của bàn tay $(p<0,05)$. Tại thời điểm T2, nhóm dùng nẹp cố tay có sự cải thiện tốt hơn so với nhóm chứng về các chỉ số của thang điểm Boston: mức độ đau, thời gian đau, yếu tay, tê bị, dị cảm,khả năng cầm đồ vật, viết, tắm và mặc quần áo.

4.2.1. Cải thiên chỉ số trên siêu âm và tốc độ dẫn truyển thần kinh. Cả 2 nhóm $\mathrm{BN}$ đều có sự cải thiện kết quả trên siêu âm và đo tốc độ dẫn truyền thần kinh giữa so với trước điều tri với $p<0,05$. Tại thời điểm $T 2$, nhóm dùng nẹp cổ tay có sự cải thiện tốt hơn so với nhóm chứng, sự cải thiện có ý nghĩa thống kê với $\mathrm{p}<0,05$ (Bảng 1.3, Bảng 1.4).

4.3. Khảo sát một số yếu tố liên quan đến kết quả điêuu trị: Tuổi và BMI có tương quan nghịch với sự thay đổi điểm VAS; sự thay đổi điểm Boston triệu chứng và chức năng $(r<0$ $\mathrm{p}<0.05)$. Nep cổ tay có hiệu quả tốt hơn trên bệnh nhân trẻ tuổi và $B M I \leq 23 \mathrm{~kg} / \mathrm{m}^{2}$ (Bảng 1.5)

\section{KẾT LUÂNN}

Điều trị HCOCT bằng phương pháp uống thuốc đơn thuần và uống thuốc kết hợp nẹp cồ tay đều giúp cải thiện cả triệu chứng lâm sàng và điện cơ cũng như diện tích thần kinh giữa trên siêu âm tuy nhiên phương pháp kết hợp nẹp cổ tay giúp cải thiện tốt hơn tại thời điểm T2 $(p<0,05)$.

Tuổi và BMI có tương quan nghịch với sự thay đổi điểm VAS, sự thay đổi điểm Boston triệu chứng và chức năng $(r<0, p<0.05)$.

\section{TÀI LIỆU THAM KHẢO}

1. Lê Thi Liễu. Nghiên cứu đăc đi $m$ lâm sàng, điên cơ và siêu âm Doppler năng lượng trong hội chứng ống cổ tay. Published online 2017. 88-100

2. Phan Hồng Minh, Lê Quang Cường (2018). Đặc điểm lẩm sàng của hội chứng ống cổ tay vô căn ở người trưởng thành, Tạp chí Y học thực hành, 8(1076), 62-63.

3. Padua L, Coraci D, Erra C, et al. Carpal tunnel syndrome: clinical features, diagnosis, and management. Lancet Neurol. 2016;15(12).

4. Riasi H, Rajabpour Sanati A, Salehi F, Salehian $\mathbf{H}$, Ghaemi K. Analyzing the therapeutic effects of short wrist splint in patients with carpal tunnel syndrome (CTS) under ibuprofen treatment from an EMG-NCV perspective. J Med Life. 2015;8 (Spec Iss 4):154-158. 


\title{
ĐĂC ĐIỂM NHÂN TRẮC, CẤU TRÚC CƠ THỂ VÀ TÌNH TRẠNG DINH DƯỠ'NG CỦA PHU NŨ̃ 15 - 35 TUỔI TẠI 5 XÃ NGHÈO CỦA HUYÊ̂N THUẬN CHÂU, TỈNH SƠN LA NĂM 2018
}

\author{
Nguyễn Song Tú ${ }^{1}$, Hồ Thị Thìn ${ }^{2}$, \\ Hoàng Nguyễn Phương Linh' ${ }^{\mathbf{1}}$, Nguyễn Thúy Anh ${ }^{\mathbf{1}}$
}

\section{TÓM TẮT}

Các dữ liêu thông tin về cấu trúc cơ thể và tình trạng dinh dưỡng phụ nữ tuổi sinh đẻ (PNTSĐ) tại các huyê̂n nghèo miên núi phía Bắc còn han chế. Nghiên cứu mô tả cắt ngang tiến hành trên 414 phụ nữ 15-35 tuổi tại 5 xã nghèo của huyện Thuận Châu, tỉnh Sơn La năm 2018 nhằm mô tả đặc điểm nhân trắc học, cấu trúc cơ thể và tình trang dinh dưỡng. Kết quả cho thấy cân nă̆ng, chiều cao và chỉ số khối cơ thể trung bình lần lượt là $\left(48,1 \mathrm{~kg}, 152,9 \mathrm{~cm}\right.$ và $\left.20,6 \mathrm{~kg} / \mathrm{cm}^{2}\right)$. Tý lệ suy dinh dưỡng (SDD) thấp còi của đối tượng nhóm 15-19 tuổi là 20,4\%; Thiếu năng lượng trượng diễn (CED) ở nhóm 20- 24 tuổi cao nhất $(26,6 \%)$ so với tỷ lệ chung $16,2 \%$ phụ nữ 20-35 tuổi. Cân nặng thấp dưới 45kg, chiếm 34,8\%. Cân nặng, chỉ số khối cơ thể, phần trăm mõ cơ thể (\%BF) và khối lượng mõ (FM) có sự thay đổi theo lớp tuổi tăng dân; \%BF và $F M$ nhóm 15-19 tuổi là thấp nhất tương ứng $(23,7 \%$ và $10,9 \mathrm{~kg})$ và nhóm $30-$ 35 tuổi cao nhất tương ứng $(29,1 \%$ và $15,2 \mathrm{~kg})$. Tỷ lê SDD thấp còi và CED còn cao ở PNTSĐ, đặc biệt là nhóm tuổi 15-24 tuổi do vâyy cần can thiệp cải thiện tình trạng dinh dưỡng cho PNTSĐ tại các xã nghèo, ưu tiên nhóm tuổi dưới 25 tuổi.

Tư khóa: Thiếu năng lượng trường diễn, cấu trúc cơ thể, tình trạng dinh dưỡng, phụ nữ tuổi sinh đẻ.

\section{SUMMARY \\ CHARACTERISTICS OF ANTHROPOMETRICS, BODY COMPOSITION AND NUTRITIONAL STATUS OF WOMEN AGED 15-35 YEARS OLD OF FIVE POOR COMMUNES IN THUAN CHAU DISTRICT, SON LA PROVINCE, 2018}

Limited information and data on the body composition and nutritional status of women of childbearing age in the poor northern mountainous districts. A cross-sectional study was conducted on 414 women aged $15-35$ years old in 5 poor communes of Thuan Chau district, Son La province in 2018 to describe anthropometric characteristics, body composition, nutritional status. Theo result showed that average weight, height and body mass index were $\left(48.1 \mathrm{~kg}, 152.9 \mathrm{~cm}\right.$ and $\left.20.6 \mathrm{~kg} / \mathrm{cm}^{2}\right)$, respectively. The prevalance of stunting of women aged 15-19 years was $20.4 \%$; chronic energy deficiency in the 20 -

\footnotetext{
${ }^{1}$ Viện Dinh dưỡng Quốc Gia, Hà Nội

${ }^{2}$ Công ty TNHH Lavichem

Chịu trách nhiệm chính: Nguyễn Song Tú

Email: nguyensongtu@yahoo.com

Ngày nhận bài: 22.6.2021

Ngày phản biện khoa học: 16.8.2021

Ngày duyệt bài: 23.6.2021
}

24 age group was the highest $(26.6 \%)$ compared to the general prevalance of $16.2 \%$ of women $20-35$ years old. Women with low weight less than $45 \mathrm{~kg}$ took $34.8 \%$. Weight, body mass index, percentage of body fat (\%BF) and fat mass (FM) changed with increasing age class. \%BF and FM were the lowest in the 15-19 age group, respectively $(23.7 \%$ and $10.9 \mathrm{~kg})$ and the highest in the $30-35$-year-old group $(29.1 \%$ and 15.2 $\mathrm{kg}$ ) respectively. The prevalence of stunting and CED is still high among women of childbearing age, especially in the age group of 15-24 years. Therefore, it is necessary to intervene to improve the nutritional status of women of childbearing age in poor communes, with priority given to the age group under 25 years old.

Keywords: Chronic energy deficiency, body composition, nutritional status, women of reproductive age.

\section{I. ĐĂT VẤN ĐỀ}

Tình trang dinh dương (TTDD) của phụ nữ tuổi sinh đẻ (PNTSĐ) nói chung không chỉ có tác động trực tiếp đến sức khỏe của chính bản thân bà mẹ mà còn có mối liên quan đến TTDD của trẻ em khi sinh ra. Nghiên cứu của Dekker và cộng sự cho thấy tỷ lệ suy dinh dưỡng thấp còi tăng khi chiều cao và BMI của bà mẹ giảm, không chỉ vậy, nghiên cứu còn cho thây mối liên quan giữa tỷ lệ mắc nhiễm trùng đường hô hấp của trẻ với TTDD của bà mẹ, cụ thể là những phụ nữ mà có BMI thấp thì con của họ sẽ có xu hướng mắc các bệnh nhiếm trùng đường hô hấp cao hơn những phụ nữ có BMI trong ngưỡng bình thường [1]. Tại Việt Nam, kết quả của Tổng điêu tra Dinh dưỡng toàn quốc (2019-2020) cho thấy tỷ lệ trẻ em dưới 5 tuổi bị suy dinh dưỡng (SDD) thấp còi đã giảm còn $19,6 \%$ và được xếp vào mức trung bình theo tiêu chuẩn của Tổ chức Y tế Thế giới. Tuy nhiên, vẫn còn sự chênh lệch giữa các vùng miền về tỷ lệ SDD thấp còi, ở các vùng nông thôn và miền núi tỷ lệ này còn cao [2]. Chính vì vậy, việc theo dõi, giám sát TTDD của PNTSĐ sẽ góp phân cung cấp chỉ số đánh giá tâm vóc của người Việt, là căn cứ cơ sở đưa ra những giải pháp can thiệp giúp cải thiện TTDD của thế hêe tương lai. Một số nghiên cứu trước đây cho thấy tỷ lệ thiếu năng lượng trường diễn (CED) của PNTSĐ khá cao, cụ thể tại Bắc Giang năm 2012, cho thấy PNTSĐ có tỷ lệ CED chiếm 39,1\%[3]. Ở Ethiopia, nghiên cứu của Ferede 
cũng cho thấy tỷ lệ CED của PNTSĐ chiếm tỷ lệ cao $(48,6 \%)$. Nguyên nhân là do những người phụ nữ này không có khả năng mua được thực phẩm giàu dinh dưỡng cho dù nguồn thực phẩm giàu dinh dưỡng tại đây luôn có sẵn [4].

Tại Việt Nam, mặc dù đã có một số nghiên cứu về TTDD của PNTSĐ nhưng việc tìm hiểu, đánh giá các giá trị nhân trắc, cấu trúc cơ thể, TTDD ở phụ nữ theo từng vùng địa lý, sinh thái vẫn còn thiếu nhiều dữ liệu và chưa có nhiều nghiên cứu đề cập tới một cách tổng thể và hệ thống, trong khi đó việc ảnh hưởng của các yếu tố sinh thái lên TTDD cũng như đặc điểm nhân trắc, cấu trúc cơ thể của phụ nữ là cơ sở dữ liệu rất quan trọng. Chính vì lý do đó, chúng tôi đã tiến hành nghiên cứu đặc điểm nhân trắc, cấu trúc cơ thể và TTDD của phụ nữ 15-35 tuổi tại các xã nghèo của huyện Thuận Châu, tỉnh Sơn La để có cơ sở dữ liệu nhằm nâng cao chất lượng chăm sóc dinh dưỡng, từ đó giúp nâng cao thể lực cho phụ nữ Việt Nam.

\section{II. ĐỐI TƯỢNG VÀ PHƯƠNG PHÁP NGHIÊN CỨU}

2.1. Đối tượng nghiên cứu. Phụ nữ trong độ tuổi 15-35, không nuôi con bú dưới 12 tháng, không có thai; không dị tật bẩm sinh về hình thể, không rối loạn tâm thần, cam kết chấp thuận tham gia.

2.2. Địa điểm và thời gian nghiên cứu. Nghiên cứu thực hiện tại 5 xã của huyện Thuận Châu, tỉnh Sơn La trong thời gian từ tháng 07/2018 đến tháng 12/2018.

2.3. Thiết kế nghiên cứu. Nghiên cứu mô tả cắt ngang

\subsection{Cỡ mẫu nghiên cứu}

*Xác định tình trạng CED:

Áp dụng công thức:

$$
\mathrm{n}=\frac{\mathrm{Z}^{2}(1-a / 2) \cdot \mathrm{p}(1-\mathrm{p}) \times \mathrm{DE}}{\mathrm{d}^{2}}
$$

Trong đó: $\mathrm{n}$ là số đối tượng cần; $\mathrm{p}$ là tỷ lệ CED ở PNTSĐ, năm 2014 là 15,1\% [5]; d là khoảng sai lệch chấp nhận được. Chọn $d=0,05$; $\alpha$ : ở mức ý nghĩa thống kê (YNTK) lấy là 0,05 ; $Z_{(1-\alpha / 2)}$ : giá trị $Z$ thu được với giá trị $\alpha=0,05$ là 1,96; DE (Design effect - hiệu ứng thiết kế) $=2$; Cõ̃ mẫu cần điều tra là 400 đối tượng. Thêm $10 \%$ đề phòng đối tượng vắng mă̆t. Do đó cõ mẫu cần là 433 đối tượng. Thực tể, nghiên cứu đã điều tra 414 đối tượng.

\subsection{Phương pháp chọn mẫu}

Chọn tỉnh: Chọn chủ đích huyện Thuận Châu, tỉnh Sơn La một tỉnh miền núi phía Bắc, nơi có hoàn cảnh kinh tế khó khăn.
Chọn xã: Chọn ngẫu nhiên đơn 5 xã trong số 27 /29 xã nghèo được là (xã Chiềng Bôm, Nậm Lầu, Tông Lạnh, Chiềng Pha, Mường Khiêng).

Chọn đối tượng nghiên cứu: theo phương pháp ngẫu nhiên hệ thống.

\subsection{Phương pháp và công cụ thu thập} số liệu

+ Tính tuổi: Toàn bộ phụ nữ sinh sau ngày 01/10/1983 đến trước ngày 01/10/2003 được lựa chọn.

+ Phỏng vấn: sử dụng bộ câu hỏi được thử nghiệm trước khi điều tra.

+ Cân đo nhân trắc: (chiêu cao, cân nặng). Dụng cụ là cân điện tử TANITA SC 330 với độ chính xác $0,1 \mathrm{~kg}$, có chức năng tự tính toán các thông số phần trăm mõ cơ thể, khối mõ, khối lượng cơ ước tính, khối không mõ. Đo chiều cao đứng sử dụng thước gỗ 3 mảnh có độ chính xác tới $1 \mathrm{~mm}$.

2.7. Một số tiêu chuẩn xác định, đánh giá. Đánh giá TTDD của phụ nữ từ 15-19 tuổi: Dựa vào quần thể chuẩn của Tổ chức $Y$ tế thế giới (WHO) 2006: Z-score chiều cao theo tuổi < 2 là SDD thể thấp còi; Z-score BMI theo tuổi < 2 là SDD thể gầy còm và $-2 \leq$ Z-score $\leq 1$ là bình thường

Chỉ số khối cơ thể (BMI) để đánh giá TTDD của người trưởng thành. BMI được tính bằng cân nặng $(\mathrm{kg}) / \mathrm{chiêu} \mathrm{CaO}^{2}(\mathrm{~m})$.

Cân nặng thấp là khi < $45 \mathrm{~kg}$; chiều cao thấp là $<145 \mathrm{~cm}$

Phân loại TTDD của người trưởng thành theo WHO năm 2000 là: CED độ III khi BMI < 16; CED độ II khi BMI từ 16,0 đến 16,99; Gầy độ I khi BMI từ 17 - 18,49; Bình thường khi BMI từ 18,5 - 24,9. Đánh giá mức độ CED trên quần thể về YNSKCĐ theo WHO: Mức độ nhe khi CED 59\%; Trung bình khi CED 10-19\%; Nặng khi CED 20-39\%; Rất nặng khi CED $\geq 40 \%$.

2.8. Phân tích và xử lý số liệu. Sử dụng phần mềm Epi Data 3.1 để nhập liệu và SPSS 18.0 để phân tích. Test kiểm định thống kê là $\chi^{2}$ test so sánh giá trị tỷ lệ, $\mathrm{t}$ - test so sánh giá trị trung bình giữa 2 nhóm, ANOVA test so sánh giá trị TB của 3 nhóm Giá trị $p<0,05$ được xem có ý nghĩa thống kê (YNTK).

2.9. Đạo đức nghiên cứu. Nghiên cứu đã được chấp thuận bởi Hội đồng đạo đức của Viện Dinh dưỡng theo quyết định số 1474 /QĐ-VDD ngày 14/09/2018.

\section{KẾT QUẢ NGHIÊN CỨU}

Nghiên cứu đã tiến hành trên 414 đối tượng tại 5 xã thuộc huyện Thuận Châu, tỉnh Sơn La, 
trong đó $93,2 \%$ là người dân tộc Thái, còn lại $6,8 \%$ là dân tộc khác (Kinh, H'mông, Dao, Khơ mú, Laha). Tuổi trung bình là 24,5 $\pm 6,2 ;$ Kinh tế hộ gia đình 45,4\% là hộ nghèo và 22,5\% là cận nghèo; nông nghiệp là nghề nghiệp đem lại thu nhập chính (82,4\%).

Bảng 1. Đặc điểm chiều cao, cân nặng và BMI của đôî tượng nghiên cứu

\begin{tabular}{|c|c|c|c|c|c|c|c|c|c|c|}
\hline Nhóm tuối & $\mathbf{n}$ & \multicolumn{3}{|c|}{ Cân nặng (kg) ${ }^{c 3}$} & \multicolumn{3}{|c|}{ Chiều cao $(\mathrm{cm})$} & \multicolumn{3}{|c|}{ Chỉ số BMI ${ }^{\mathrm{c} 3}$} \\
\hline 15-19 tuổi & 112 & 44,8 & \pm & 6,0 & 152,9 & \pm & 4,9 & 19,1 & \pm & 2,2 \\
\hline 20-24 tuổi & 96 & 47,5 & \pm & 6,2 & 152,9 & \pm & 4,9 & 20,3 & \pm & 2,4 \\
\hline 25-29 tuổi & 99 & 49,0 & \pm & 5,9 & 152,6 & \pm & 4,9 & 21,0 & \pm & 2,2 \\
\hline 30-35 tuổi & 107 & 51,1 & \pm & 7,3 & 153,1 & \pm & 5,0 & 21,8 & \pm & 2,8 \\
\hline Chung & 414 & 48,1 & \pm & 6,8 & 152,9 & \pm & 4,9 & 20,6 & \pm & 2,6 \\
\hline
\end{tabular}

TB \pm SD: trung bình; độ lệch chuần; ${ }^{3)} p<0,001$ c)ANOVA-test so sánh chỉ số giữa các lớp tuối

Cân nặng trung bình ĐTNC cao nhất là lớp tuổi 30-35 tuổi (51,1 kg) khác biệt có YNTK với 3 nhóm tuổi còn lại (post hoc test, $p<0,05$ ); Chỉ số khối cơ thể BMI của ĐTNC tăng dần theo lớp tuổi tăng dần, có khác biệt có YNTK theo từng lớp tuổi $(p<0,001)$;

Bảng 2. Chỉ số phần trăm mõ̃, khôi lượng mõ̃ của đôii tượng nghiên cứu

\begin{tabular}{|c|c|c|c|c|c|c|c|}
\hline Nhóm tuối & n & \multicolumn{2}{|c|}{ Phần trăm mõ (\%) } & \multicolumn{3}{c|}{ Khối lướng mỡ (kg) $\mathbf{~} \mathbf{c}^{\mathbf{c}}$} \\
\hline $15-19$ tuô̂i & 112 & 23,7 & \pm & $4,8^{\mathrm{c} 1}$ & 10,9 & \pm & 3,4 \\
\hline $20-24$ tuô̂i & 96 & 26,3 & \pm & $4,5^{\mathrm{c} 1}$ & 12,7 & \pm & 3,7 \\
\hline $25-29$ tuối & 99 & 28,1 & \pm & 3,7 & 13,9 & \pm & 3,5 \\
\hline $30-35$ tuối & 107 & 29,1 & \pm & 4,7 & 15,2 & \pm & 4,5 \\
\hline Chung & 414 & 26,7 & \pm & 4,9 & 13,1 & \pm & 4,1 \\
\hline
\end{tabular}

TB \pm SD: trung bình; độ lệch chuấn; ${ }^{1)} p<0,05 ;{ }^{2)} p<0,01 ;{ }^{c}$ ) ANOVA-test

Phần trăm mỡ cơ thể (\%BF) và khối lượng mớ (FM) ở ĐTNC có sự thay đổi tăng dần theo lớp tuổi $(p<0,05)$; Chỉ số \%BF ở ĐTNC giữa các nhóm tuối $15-19$ và $20-24$ khác biệt có YNTK với các nhóm tuổi còn lại (post hoc test, $p<0,05$; Khối lượng mõ (FM) ở ĐTNC khác biệt có YNTK giữa các nhóm tuổi với nhau $(p<0,01)$.

Bảng 3. Đặc điểm khôi cớ và khối không mỡ của đôî tượng nghiên cứu

\begin{tabular}{|c|c|c|c|c|c|c|c|}
\hline Nhóm tuối & \multicolumn{2}{|c|}{ Khối lượng cơ ước tính (\%) } & \multicolumn{3}{|c|}{ Khối lượng không mõ (kg) } \\
\hline $15-19$ tuối & 112 & 32,1 & \pm & $2,8^{\mathrm{c1}}$ & 34,0 & \pm & 3,0 \\
\hline $20-24$ tuối & 96 & 32,9 & \pm & 2,8 & 34,8 & \pm & 3,1 \\
\hline $25-29$ tuối & 99 & 33,1 & \pm & 2,6 & 35,0 & \pm & 2,8 \\
\hline $30-35$ tuối & 107 & 34,0 & \pm & $3,0^{\mathrm{c} 1}$ & 35,9 & \pm & $3,3^{\mathrm{c}}$ \\
\hline Chung & 414 & 33,0 & \pm & 2,9 & 34,9 & \pm & 3,1 \\
\hline
\end{tabular}

TB \pm SD: trung bình; độ lệch chuấn; ${ }^{3)} p<0,001 \quad$ c) ANOVA-test

Khối lượng cơ ước tính (PMM), khối lượng không mõ (FFM) ở ĐTNC tăng dần theo nhóm tuổi tăng dần có YNTK $(p<0,001)$. PMM ở ĐTNC nhóm tuổi $15-19$ và 30-35 khác biệt có YNTK với 3 nhóm tuổi kia (post hoc test, $\mathrm{p}<0,05$ ) và FFM ở ĐTNC nhóm tuổi 30-35 khác biệt có YNTK với 3 nhóm tuổi kia (post hoc test, $\mathrm{p}<0,05$ );

Bảng 4. Các chỉ số nhân trắc và tình trạng dinh dướng của phụ nữ 15-35 tuối

\begin{tabular}{|c|c|c|c|}
\hline \multicolumn{2}{|c|}{ Các chỉ số } & $\mathbf{n}$ & TB \pm SD \\
\hline \multicolumn{2}{|c|}{ Cân nặng trung bình (kg) } & 414 & $48,1 \pm 6,8$ \\
\hline \multicolumn{2}{|c|}{ Chiều cao TB của ĐTNC $(\mathrm{cm})$} & 414 & $152,9 \pm 4,9$ \\
\hline \multicolumn{2}{|c|}{ BMI trung bình $\left(\mathrm{kg} / \mathrm{m}^{2}\right)$} & 414 & $20,6 \pm 2,6$ \\
\hline \multirow{2}{*}{$\begin{array}{l}\text { BMI trung } \\
\text { bình theo } \\
\text { nhóm tuổi } \\
\left(\mathrm{kg} / \mathrm{m}^{2}\right)\end{array}$} & $15-19$ tuối & 112 & $19, \pm 2,1^{\mathrm{a} 3}$ \\
\hline & 35 tuối & 302 & $\pm 2,6$ \\
\hline \multicolumn{2}{|c|}{ Các chỉ số } & n & Tỷ lệ \% \\
\hline \multirow{2}{*}{$\begin{array}{l}\text { ĐTNC có } \\
\text { cân nặng } \\
\text { thấp }\end{array}$} & $\begin{array}{c}\text { Toàn bộ đối } \\
\text { tượng ( } \mathrm{n}=414)\end{array}$ & 144 & 34,8 \\
\hline & $\begin{array}{c}\text { Từ 15-24 tuối } \\
(n=208)\end{array}$ & 96 & 66,7 \\
\hline
\end{tabular}

\begin{tabular}{|c|c|c|c|}
\hline \multicolumn{2}{|c|}{$\begin{array}{l}\text { DTNC có chiều cao thấp } \\
(\mathrm{n}=414)\end{array}$} & 22 & 5,3 \\
\hline \multicolumn{2}{|c|}{$\begin{array}{l}\text { SDD gây còm } 15-19 \text { tuối } \\
(n=103)\end{array}$} & 8 & 7,8 \\
\hline \multicolumn{2}{|c|}{$\begin{array}{l}\text { CED của nhóm 20-35 tuối } \\
(n=302)\end{array}$} & 49 & 16,2 \\
\hline \multirow{3}{*}{$\begin{array}{l}\text { CED theo } \\
\text { mức độ }\end{array}$} & Độ $1(n=302)$ & 42 & 13,9 \\
\hline & Độ $2(n=302)$ & 5 & 1,7 \\
\hline & Độ $3(n=302)$ & 2 & 0,6 \\
\hline
\end{tabular}

a) t-test ${ }^{1} p<0,05,{ }^{2} p<0,01,{ }^{3} p<0,001$;

BMI trung bình của đối tương là 20,6 2,6 $\mathrm{kg} / \mathrm{m}^{2}$; Có khác biệt có YNTK về chỉ số BMI trung bình giữa 2 nhóm $15-19$ và $20-35$ tuổi ( $p<$ 0,001 ). Tỷ lệ đối tượng có cân nặng thấp (dưới $45 \mathrm{~kg}$ ) là $34,8 \%$ và có chiều cao thấp (dưới 
$145 \mathrm{~cm}$ ) là 5,3\%;. Số phụ nữ CED là 16,2\%; chủ yếu là CED độ 1 (13,9\%).

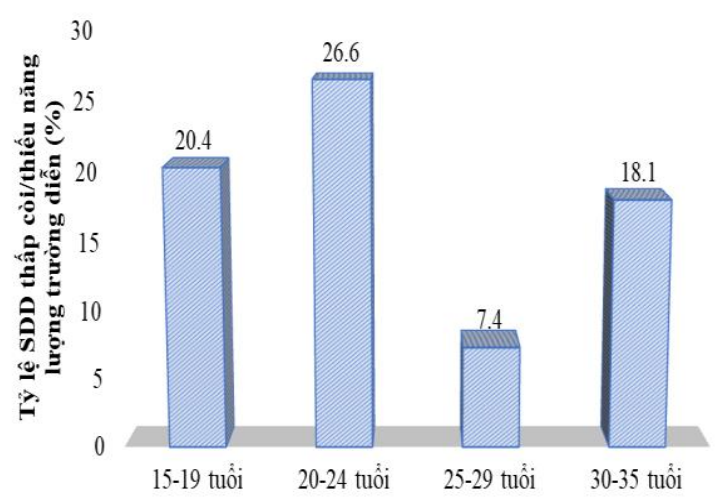

$\chi^{2}$ - test so sánh giá trị tỷ lệ CED giữa các lớp tuổi, $\mathrm{p}<0.001$

Hình 1. Tỷ lê SDD thấp còi nhóm 15-19 tuổi và CED các nhóm từ 20 -35 tuổi

Tỷ lê SDD thấp còi ở nhóm 15 - 19 tuổi là 20,4 và CED ở nhóm tuổi 20 - 24 cao nhất là $26,6 \%$.

\section{BÀN LUẬN}

Chiều cao trung bình của đối tượng nghiên cứu (ĐTNC) là 152,9 $9 \pm 4,9 \mathrm{~cm}$, tương đương với chiều cao nữ thanh niên Việt Nam năm 2000 $(152,3 \mathrm{~cm})$; nhưng thấp hơn đối tượng này năm $2010(154,8 \mathrm{~cm})$ và năm $2020(156,2 \mathrm{~cm})$ [2]; cho thấy rằng chiều cao phụ nữ các xã nghèo nơi có $93,2 \%$ là dân tộc Thái, vùng miền núi dường như đã không cải thiện sau hơn thập kỷ; ngoài vấn đề dinh dưỡng, đây cũng có thể là hậu quả của tình trạng SDD thấp còi của những đối tượng này trong những năm đầu đời.

Tỷ lệ CED của phụ nữ $15-35$ tuổi là 16,2\%, thấp hớn nghiên cứu PNTSĐ dân tộc Nùng tại Bắc Giang, tỷ lệ là 33,6\% [3], thấp hơn ở Ethiopia, tỳ lệ PNTSĐ CED là 48,6\% [4]; nhưng cao hơn đáng kể so với PNTSÐ của người $H^{\prime}$ Mông, Cao Bằng $(2,1 \%)[6]$ và PNTSĐ ở Oman $(9,1 \%)$ [7]. Sự khác biệt này cũng được giải thích là do sự khác biệt về điều kiện kinh tế, xã hội của từng khu vực địa lý nơi mà PNTSĐ đang sinh sống; cũng như vắn hóa. Ở Oman, phụ nữ được sống trong môi trường có điều kiện kinh tế tốt do đó tỷ lệ PNTSĐ bị CED thấp mà thay vào đó là một lượng lớn PNTSĐ có tình trạng thừa cân, béo phì $(52,9 \%)$ [7]. Sự khác nhau về tỷ lệ CED ở ĐTNC so với nghiên cứu trên người $\mathrm{H}^{\prime}$ Mông tại Cao Bằng có thể giải thích là do chiều cao của PNTSĐ của người $H^{\prime}$ Mông rất thấp là $(148,5 \pm 4,2 \mathrm{~cm})[6]$, thấp hơn đáng kể so với chiều cao TB của phụ nữ trưởng thành của Việt Nam [2]; trong khi cân nặng khác biệt không nhiều, do đó BMI của nhiều PNTSĐ người $\mathrm{H}^{\prime}$ Mông nằm trong giới hạn bình thường và tỷ lệ CED không cao [6]. Đồng thời, tỷ lệ CED của ĐTNC trong độ tuổi 20-24 chiếm cao nhất là $26,6 \%$. Tỷ lệ này tương đồng với kết quả trong nghiên cứu Tổng điêuu tra dinh dưỡng trên phạm vi toàn quốc năm 2010: tỷ lệ CED của PNTSĐ 20-49 dao động từ 13,5\% tới 27,7\%, trong đó nhóm 20-24 tuổi có tỷ lệ CED cao nhất: $27,7 \%$. Phụ nữ trong độ tuổi 20-24 là độ tuổi chuẩn bị cho việc kết hôn, mang thai ở phụ nữ nông thôn, nhưng tỷ lệ CED cao, điều này sẽ dẫn tới hậu quả là làm tăng nguy cơ dẫn đến đứa con của họ sinh ra suy dinh dưỡng (SDD). Do vậy, cần có các hoạt động can thiệp dinh dưỡng đặc thù, tăng cường tuyên truyền, giáo dục về dinh dưỡng cho phụ nữ trong độ tuổi 20-24 để nhằm thay đổi nhận thức, thói quen thực hành dinh dưỡng cho phụ nữ trong lứa tuổi này, góp phần cải thiện tỷ lệ SDD ở trẻ em trong tương lai.

Phần trăm mõ cơ thể (\%BF) TB chung của ĐTNC là $26,7 \pm 4,9 \%$ ở ngưỡng TB theo WHO 1995, tỷ lệ này thấp hơn so với PNTSĐ người H'Mông là: $28,8 \pm 3,9 \%$ [6]. Sự khác biệt này có thể giải thích là do chiều cao của người $\mathrm{H}^{\prime}$ Mông ở tỉnh Cao Bằng $(148,5 \pm 4,2 \mathrm{~cm})$ thấp hơn chiều cao của phụ nữ trong nghiên cứu của chúng tôi $(152,9 \pm 4,9 \mathrm{~cm})$, trong khi cân nặng $(48,1 \pm 6,8$ $\mathrm{kg}$ ) của ĐTNC thì lại tương đương so với PNTSÐ H'Mông $(48,1 \pm 5,2$ kg) [6]; Khối lượng cơ ước tính, khối lượng không mõ của ĐTNC lần lượt là $33,0 \pm 2,9 \mathrm{~kg}$ và $34,9 \pm 3,1 \mathrm{~kg}$, cao hơn phụ nũ H'mông $(32,2 \mathrm{~kg})[6]$; nhưng chỉ số này thấp hơn so với khối lượng cơ TB của phụ nữ ở Serbia $(39,30 \pm 5,25 \%)$ [8]. Sự khác biệt này có thể giải thích là do những PNTSĐ này có sự khác biệt về chủng tộc và môi trường sống. ĐTNC của chúng tôi chủ yếu là ở nông thôn, nghề nghiệp chính là học sinh và làm nông; trong giai đoạn này là giai đoạn phát triển và tăng trưởng; nhu cầu về dinh dưỡng tăng cao; đồng thời nếu là học sinh thì tập trung học tập với cường độ cao; nếu là phụ nữ thì bắt đầu giai đoạn xây dựng gia đình do đó việc học tập và lao động vất vả, cùng với nhu cầu dinh dưỡng không được đáp ứng đủ sẽ dẫn đến các chỉ số cấu trúc cơ thể thấp hơn.

\section{KẾT LUẬN}

Nghiên cứu trên 414 phụ nữ 15-35 tuổi tai 5 xã nghèo huyện Thuận Châu cho thấy cân nặng trung bình (TB) là 48,1kg; chiều cao TB là 152,9 cm; chỉ số khối cơ thể (BMI) TB là $20,6 \mathrm{~kg} / \mathrm{cm}^{2}$. Tỷ lệ phụ nữ có cân nặng thấp dưới $45 \mathrm{~kg}$, chiếm $34,8 \%$. Tỷ lệ SDD thấp còi của nhóm 15-19 tuổi 
là 20,4\%; CED nhóm 20- 24 cao nhất (26,6\%) so với tỷ lệ chung 16,2\% ở phụ nữ 20-35 tuổi. Cân nặng, BMI, phân trăm mỡ (\%BF) và khối lượng mỡ (FM), khối lượng cơ ước tính (PMM), khối lượng không mõ (FFM) có sự thay đổi theo lớp tuổi tăng dân. Tỷ lệ SDD thấp còi và CED còn cao ở PNTSĐ, đặc biệt là nhóm tuổi 15-24 tuổi, cân tiếp tục đâuu tư các hoạt động can thiệp dinh dưỡng, tăng cường giáo dục truyền thông nhằm cải thiện tình trạng dinh dưỡng cho đối tượng này, đặc biệt ưu tiên cho PNTSĐ ở nhóm tuổi dưới 25 tuổi tại Sơn La.

\section{TÀI LIỆU THAM KHẢO}

1. Dekker LH, Mora-Plazas M, Marín $C$ et al. Stunting Associated with Poor Socioeconomic and Maternal Nutrition Status and Respiratory Morbidity in Colombian Schoolchildren. Food and Nutrition Bulletin, 2010; 31(2): 242 - 250.

2. Viện Dính dướng. Báo cáo sơ bộ kết quả Tổng điêu tra Dinh dưỡng toàn quốc 2019 - 2020. Hội nghị Công bố kết quả Tổng điêu tra dinh dưỡng, 20211.

3. Đinh Thị Phương Hoa, Lê Thị Hợp, Phạm Thị Thúy Hòa. Thực trạng thiếu máu, tînh trạng dinh dưỡng và nhiếm giun ở phụ nữ 20-35 tuổi tại xã thuộc huyên Lục Nam, Bắc Giang. Tạp chí Dinh dưỡng \& Thực phẩm, 2012; 8(1): 39-46.

4. Ferede $A$, Lemessa $F$, Tafa $M$, Sisay $S$. The prevalence of malnutrition and its associated risk factors among women of reproductive age in Ziway Dugda district, Arsi Zone, Oromia Regional State, Ethiopia. Public Health, 2017; 152: 1-8.

5. Viện Dinh dưỡng, Báo cáo kết quả điều tra dinh dưỡng toàn quốc hàng năm cập nhật đến 2019. Website: http://viendinhduong.vn, 2021.

6. Nguyê̂n Quang Dũng, Nguyễn Lân, Lê Danh Tuyên. Tình trạng dinh dướng, đặc điểm cấu trúc cơ thể của phụ nữ tuổi sinh đẻ người $\mathrm{H}^{\prime}$ Mông tại huyện Bảo Lạc, tỉnh Cao Bằng. Tình hình dinh dưỡing chiến lước can thiêp 2011-2015 và đinh hướng 2016-2020 Nhà xuất bản Y học, 2017; 104-111.

7. Petry N, Al-Mamary S A, Woodruff BA, Alghannami S. National Prevalence of Micronutrient Deficiencies, Anaemia, Genetic Blood Disorders and Over- and Undernutrition in Omani Women of Reproductive Age and Preschool Children. Sultan Qaboos University Med J, 2020; 20(2): e151-164.

8. Sladjana R, Milivej D, Marina DN, Nadja V. Profile and reference values for body fat and skeletal muscle mass percent at females, aged from 18.0 to 69.0, measured by Multichannel Segmental Bioimpedance method: Serbian population study. Int. J. Morphol, 2019; 37(4): 1286-1293.

\section{MộT Số YẾU TỐ LIÊN QUAN ĐẾN KẾT QUẢ PHẪU THUÂT CẮT DİCH KÍNH ĐÎ̂̉U TRI BONG VÕNG MẠC DO LỖ HOÀNG ĐIỂM}

\section{TÓM TẮT}

Mục tiêu: Đánh giá môtt số yếu tố liên quan đến kết quả phẫu thuật cắt dịch kính điều trị bong võng mạc do lố hoàng điểm. Đối tượng và phương pháp nghiên cứu: Nghiên cứu mô tả cắt ngang gồm 52 mắt bong võng mạc do lô̂ hoàng điểm đã được phẫu thuật cắt dịch kính bóc màng ngăn trong kết hợp bơm khí nở C3F8 hoặc dầu silicon nội nhãn tại Bệnh viện Mắt Trung ương từ năm 2015 - 2019 với thời gian theo dõi tối thiểu 6 tháng. Kết quả: Tỷ lệ võng mạc áp hoàn toàn sau phấu thuật lần đâu là $80,8 \%$. Tỷ lệ đóng lỗ hoàng điểm hoàn toàn là $61,5 \%$. Thị lực trung bình tăng từ $1,99 \pm 0,31$ logMAR lên $1,35 \pm 0,26$ logMAR ở lần khám sau cùng. Thời gian bị bệnhhh trên 6 tháng, thị lực ban đâuu thấp, trục nhãn cầu trên $\geq 26 \mathrm{~mm}$, sự giä̉n phình hậu cực và kích thước lỗ hoàng điểm lớn là các yếu tố làm giảm tỷ lệ võng mạc áp hoàn toàn và khả năng đóng lố hoàng điểm. Mức độ bong võng mạc rộng làm giảm khả năng đóng lỗ hoàng điểm trong khi chất độn nội nhãn ảnh hưởng

*Bệnh viên Mắt Trung Ương

Chịu trách nhiệm chính: Nguyễn Kiếm Hiệp

Email: nguyenkiemhiep@gmail.com

Ngày nhận bài: 14.6.2021

Ngày phản biên khoa học: 9.8.2021

Ngày duyệt bài: 16.8.2021
Nguyễn Kiếm Hiệp*

đến tỷ lệ áp võng mạc sau mổ. Kích thước lỗ hoàng điểm là yếu tố ảnh hưởng duy nhất đến kết quả thị lực sau phẫu thuật $(p=0,009)$. Kết luận: Phẫu thuật cắt dịch kính điều trị bong vông mạc do lỗ hoàng điểm mang lại kết quả tốt về giải phấu tuy nhiên kết quả thị lực còn thấp. Thời gian bị bệnh, thị lực ban đầu, trục nhãn cầu, sự giãn phình hậu cực, kích thước lỗ hoàng điểm, mức độ bong võng mạc và chất độn nội nhãn là những yếu tổ ảnh hưởng đển kết quả giải phẫu trong khi kích thước lỗ hoàng điểm ảnh hưởng đến kết quả thị lực của phẫu thuật. kính

Tư khóa: bong võng mạc, lỗ hoàng điểm, cắt dịch

\section{SUMMARY}

EVALUATING THE FACTORS RELATED TO OUTCOME OF VITRECTOMY FOR RETINAL DETACHMENT CAUSED BY MACULAR HOLE

Purpose: To evaluate the factors related to outcome of vitrectomy for retinal detachment caused by macular hole. Methods: A cross-sectional descriptive study of 52 macular hole retinal detachment eyes that underwent vitrectomy in combination with inner limiting membrane peeling and intraocular gas (C3F8) or silicone oil at the Viet Nam National Institute of Ophthalmology from 2015 to 2019 with a minimum follow-up of 6 months. Results: The rate of retinal reattachment after the 
primary surgery was $80.8 \%$. The rate of macular hole closure was $61.5 \%$. Mean visual acuity increased from $1.99 \pm 0.31 \log M A R$ to $1.35 \pm 0.26 \log M A R$ at the last examination. Disease duration more than 6 months, poor preoperative visual acuity, axial length more than $26 \mathrm{~mm}$, posterior staphyloma and large macular hole size are factors that reduce the rate of retinal reattachment and macular hole closure after surgery. The extent of retinal detachment reduces the possibility of macular hole closure while intraocular tamponade affects only the rate of postoperative retinal reattachment. The size of the macular hole was the only factor affecting postoperative visual acuity ( $p$ $=0.009$ ). Conclusion: Vitrectomy for macular hole retinal detachment has good anatomical results, but postoperative visual acuity are still low. Disease duration, preoperative visual acuity, axial length, posterior staphyloma, macular hole size, extent of retinal detachment and intraocular tamponade were factors that influenced the anatomic results while the size of the macular hole affects the visual outcome of surgery.

Keywords: retinal detachment, macular hole, vitrectomy

\section{I. ĐẶT VẤN ĐỀ}

Bong võng mạc do lỗ hoàng điểm thường xuất hiện ở mắt cận thị nặng có giãn lồi hậu cực, đòi hỏi can thiệp phẫu thuật sớm bởi bì bong võng mạc do lồ hoàng điểm gây tổn thương võng mạc không hồi phục [1]. Ở mặt cận thị nặng, bong võng mạc do lố hoàng điểm được cho là do những co kéo tiếp tuyến tại vùng hoàng điểm, giãn lồi hậu cực, hoặc do teo lớp biểu mô sắc tố $[1,2]$.

Phẫu thuật cắt dịch kính, bóc màng ngăn trong kết hợp khí nở nội nhãn hoặc dầu silicon nội nhãn là phương pháp điều trị chính với tỷ lệ áp võng mạc khá cao, từ $50-90 \%[3 ; 4 ; 5]$. Tuy nhiên, bong võng mạc do lỗ hoàng điểm vẫn là một trong những loại bong võng mạc khó điều trị. Tỷ lệ bong võng mạc tái phát còn khá cao, việc đóng lỗ hoàng điểm và phục hồi thị lực vẫn còn là vấn đề khó khăn. Việc hiểu biết về các yếu tố liên quan sẽ giúp phẫu thuật viên tiên lượng tốt hơn và cải thiện kết quả phẫu thuật. Tuy nhiên ở Việt Nam hiện nay chưa có nghiên cứu nào về vấn đề này.

Vì vậy, chúng tôi tiến hành nghiên cứu nhằm đánh giá một số yếu tố liên quan đến kết quả phẫu thuật cắt dịch kính điêu trị bong võng mạc do lỗ hoàng điểm.

\section{II. ĐỐI TƯỢNG VÀ PHƯƠNG PHÁP NGHIÊN CỨU}

1. Đối tượng nghiên cứu. Nghiên cứu được tiến hành tại khoa Dịch kính - Võng mạc, Bệnh viện Mắt Trung Ương từ tháng 1/2015 đến tháng $1 / 2019$.

a) Tiêu chuẩn lựa chọn: - Bệnh nhân bị bong võng mạc do lỗ hoàng điểm.

- Lỗ hoàng điểm độ 3, 4.

- Thị lực từ nhận biết ánh sáng (ST(+)) trở lên.

- Bềnh nhân trên 18 tuổi.

- Bệnh nhân đồng ý tham gia nghiên cứu.

b) Tiêu chuẩn loại trừ:

- Bong võng mạc lố hoàng điểm nhưng có vết rách võng mạc.

- Có bệnh lý khác của nhãn cầu ảnh hưởng đến kết quả phẫu thuật như mộng độ 3 hoặc 4 , sẹo giác mạc dày.

- Bênh nhân được phẫu thuật thủy tinh thể có đặt kính nội nhãn nhưng khi phẫu thuật không đặt được kính.

- Bệnh nhân già yếu hoặc có bệnh toàn thân nặng.

- Bệnh nhân không hợp tác.

2. Phương pháp nghiên cứu. Nghiên cứu mô tả cắt ngang

Cõ mẫu: 52 bệnh nhân. Áp dụng phương pháp chọn mấu thuận tiện.

* Cách thức tiến hành:

- Khám BN trước mổ bằng sinh hiển vi, làm xét nghiệm cần thiết: siêu âm, chụp OCT bán phần sau,..

- Thu thập các thông tin vào bệnh án nghiên cứu:

+ Hành chính: tên, tuổi, giới, địa chỉ.

+ Đặc điểm lâm sàng: thời gian bị bệnh, thị lực, nhãn áp, trục nhãn cầu, giãn phình hậu cực, mức độ bong võng mạc, kích thước lỗ hoàng điểm,...

- Tiến hành phẫu thuật: gây tê cạnh nhãn cầu lydocain $2 \%$, cắt dịch kính qua pars plana với troca 23G, đầu cắt dịch kính, camera nội nhãn, thuốc nhuộm màng ngăn trong, pince bóc màng, bơm khí nở C3F8 hoặc dâu silicon nội nhãn, có hoặc không kèm theo lây thể thủy tinh đặt thể thủy tinh nhân tạo, nằm sấp 2 tuần sau phẫu thuật. Tháo dâu silicon sau 3 tháng.

- Theo dõi sau mổ ở các thời điểm sau phẫu thuật 1 ngày, 1 tuần, 1 tháng, 3 tháng, 6 tháng: khám mắt bằng sinh hiển vi, phát hiện biến chứng, đo thị lực, siêu âm, chụp OCT đánh giá võng mạc và iố hoàng điểm ở mổi thời điểm theo dõi, ghi nhận các thông tin vào bệnh án nghiên cứu.

- Xử lý và phân tích số liệu.

* Các biến số nghiên cứu:

- Kết quả giải phẫu:tỷ lệ võng mạc áp hoàn toàn, tỷ lệ đóng lỗ hoàng điểm sau phẫu thuật.

- Kết quả chức năng: thị lực sau mổ ở lần khám cuối cùng.

- Khảo sát các yếu tố liên quan đến kết quả phẫu thuật bao gồm: tuổi, giới, thời gian bi bệnh, thị lực đầu vào, trục nhãn cầu, phình giãn hậu cực, mức độ bong võng mạc, kích thước lỗ 
hoàng điểm, chất độn nỗi nhãn.

3. Xử lý số liệu. Sử dụng phần mềm thống kê SPSS 16.0 với các biến dùng thuật toán so sánh 2 nhóm Mann-Whitney $U$ tests hoăc Fisher's exact tests. Sự khác biệt có ý nghĩa thống kê khi $p<0,05$.

\section{KẾT QUẢ NGHIÊN CỨU}

Nghiên cứu gồm 52 mắt ( 52 bệnh nhân) bong võng mạc lỗ hoàng điểm được phẫu thuật cắt dịch kính, bóc màng ngăn trong, bơm khí nở hoặc dầu silicon nội nhãn tại Bênh viên Mắt Trung ương từ năm 2015 - 2019. Tỷ lệ nữ chiếm $75 \%$, tuổi trung bình là 62 ( từ $48-79$ tuổi). Thị lực trung bình trước phẫu thuật là 1,98 $\pm 0,31$ logMAR (BBT 0,1m đến 20/400)

\section{Bảng 1. Kêt quả phẫu thuật}

\begin{tabular}{|c|c|}
\hline Tỷ lệ võng mạc áp & $80,8 \%$ \\
\hline Tỷ lệ đóng lố hoàng điểm & $61,5 \%$ \\
\hline Thị lực & $1,35 \pm 0,26$ logMAR \\
(ĐNT 0,5m - 20/100) \\
\hline
\end{tabular}

Tỷ lê võng mac áp sau phẫu thuật lần đầu là 80,8\%. Có 10 bệnh nhân (19,2\%) bị bong võng mạc tái phát cần phẫu thuật lần 2 và bơm dầu silicon nội nhãn. Các trường hợp này võng mạc đều áp sau khi tháo dầu. Tỷ lệ đóng lỗ hoàng điểm hoàn toàn là $61,5 \%$, còn lại $38,5 \%$ đều có sự giảm kích thước lố so với trước khi phẫu thuật. Thị lực ở lần khám sau cùng có sự cải thiện đáng kể từ $1,99 \pm 0,31 \log M A R$ (BBT 0,1m - 20/400) lên $1,35 \pm 0,26$ logMAR (DNT 0,5m 20/100) với $\mathrm{p}<0,0001$.

\section{Bảng 2. Các yếu tố ảnh hưởng đến kêt quả giải phẫu}

\begin{tabular}{|c|c|c|c|c|c|c|c|}
\hline \multicolumn{2}{|c|}{ Các yếu tố ảnh hưởng } & $\begin{array}{l}\text { Áp hoàn } \\
\text { toàn }\end{array}$ & $\begin{array}{l}\text { BVM tái } \\
\text { phát }\end{array}$ & $\mathbf{P}$ & $\begin{array}{l}\text { Đóng } \\
\text { LHÐ }\end{array}$ & \begin{tabular}{|c|} 
Không \\
đóng LH円
\end{tabular} & p \\
\hline \multirow{2}{*}{$\begin{array}{l}\text { Thời gian } \\
\text { bị bệnh }\end{array}$} & $\leq 6$ tháng & 38 & 9 & \multirow{2}{*}{0,04} & 31 & 16 & \multirow{2}{*}{0,045} \\
\hline & $>6$ tháng & 4 & 1 & & 1 & 4 & \\
\hline \multirow{3}{*}{$\begin{array}{c}\text { Thị lực ban } \\
\text { đâu }\end{array}$} & $<20 / 100-\geq 20 / 400$ & 3 & 1 & \multirow{3}{*}{0,047} & 3 & 1 & \multirow{3}{*}{0,0084} \\
\hline & $<20 / 400-\geq$ DNT1m & 9 & 1 & & 7 & 3 & \\
\hline & $<$ DNT $1 \mathrm{~m}$ & 30 & 8 & & 22 & 16 & \\
\hline \multirow{3}{*}{$\begin{array}{l}\text { Mức đô } \\
\text { bong võng } \\
\text { mạc }\end{array}$} & Khu trú hậu cực & 33 & 6 & \multirow{3}{*}{0,351} & 27 & 12 & \multirow{3}{*}{0,04} \\
\hline & $\begin{array}{c}\text { Hậu cực } \\
\text { và } 1 \text { góc phần tư }\end{array}$ & 5 & 3 & & 2 & 6 & \\
\hline & $\begin{array}{c}\text { Hậu cực } \\
\text { và } 2 \text { góc phâan tư }\end{array}$ & 4 & 1 & & 3 & 2 & \\
\hline \multirow{3}{*}{$\begin{array}{l}\text { Trục nhãn } \\
\text { cầu }\end{array}$} & $<24 \mathrm{~mm}$ & 2 & 0 & \multirow{3}{*}{0,038} & 2 & 0 & \multirow{3}{*}{0,032} \\
\hline & $\geq 24-<26 \mathrm{~mm}$ & 5 & 0 & & 4 & 1 & \\
\hline & $\geq 26 \mathrm{~mm}$ & 35 & 10 & & 26 & 19 & \\
\hline \multirow{3}{*}{$\begin{array}{l}\text { Kích thước } \\
\text { LHĐ }\end{array}$} & $<400 \mu \mathrm{m}$ & 1 & 0 & \multirow{3}{*}{0,038} & 1 & 0 & \multirow{3}{*}{0,013} \\
\hline & $\geq 400-<600 \mu \mathrm{m}$ & 17 & 0 & & 15 & 2 & \\
\hline & $\geq 600 \mu \mathrm{m}$ & 24 & 10 & & 16 & 18 & \\
\hline \multirow{2}{*}{$\begin{array}{l}\text { Giãn phình } \\
\text { hậu cực }\end{array}$} & Có & 35 & 10 & \multirow{2}{*}{0,016} & 26 & 19 & \multirow{2}{*}{0,015} \\
\hline & Không & 7 & 0 & & 6 & 1 & \\
\hline \multirow{2}{*}{ Chất độn } & Khí nở C3F8 & 6 & 7 & \multirow{2}{*}{0,001} & 6 & 7 & \multirow{2}{*}{0,188} \\
\hline & Dầu silicon & 36 & 3 & & 26 & 13 & \\
\hline
\end{tabular}

Thời gian bị bệnh > 6 tháng, thị lực ban đầu thấp, trục nhã̉n cầu dài, kích thước lỗ hoàng điểm lớn và giãn phình hậu cực là những yếu tố ảnh hưởng đến tỷ lệ áp võng mạc và đóng lỗ hoàng điểm $(p<0,05)$. Trong khi đó mức độ bong võng mạc ảnh hưởng đến khả năng đóng lỗ hoàng điểm $(p=0,04)$ nhưng không ảnh hưởng đến tỷ lệ áp võng mạc $(p=0,351)$. Ngược lại, chất độn nội nhãn ảnh hưởng đến tỷ lệ áp võ̀ng mạc $(p=0,01)$ nhưng không ảnh hưởng đến khả năng đóng lỗ hoàng điểm ( $p=$ 0,188 ). Các yếu tố khác như tuổi, giới, tình trạng dịch kính sau, cách bóc màng giới hạn trong và thời gian nằm sấp đều không ảnh hưởng đến kết quả giải phẫu của phẫu thuật $(p>0,05)$.

Bảng 3. Ánh hướng của kích thước lố hoàng điểm đến thị lực sau mố

\begin{tabular}{|c|c|c|c|}
\hline $\begin{array}{l}\text { Kêt quả } \\
\text { thị lực }\end{array}$ & $\begin{array}{l}\text { Kích thước } \\
\text { LHÐ ( } \mathrm{mm})\end{array}$ & $n(\%)$ & $\mathbf{P}$ \\
\hline$\geq 20 / 100$ & 468 & $1(1,9 \%)$ & \multirow{4}{*}{0,009} \\
\hline $\begin{array}{l}<20 / 100- \\
\geq 20 / 400\end{array}$ & 635,4 & $\begin{array}{c}27 \\
(51,9 \%) \\
\end{array}$ & \\
\hline $\begin{array}{l}<20 / 400- \\
\geq \text { DNT 1m }\end{array}$ & 761,6 & $\begin{array}{c}23 \\
(44,3 \%)\end{array}$ & \\
\hline$<$ DNT 1m & 964 & $1(1,9 \%)$ & \\
\hline
\end{tabular}

1 mắt có thị lực tốt nhất sau phẫu thuật $(\geq$ 20/100) có kích thước LHĐ nhỏ nhất là $468 \mu \mathrm{m}$ và 1 mắt có thị lực kém nhất (< ĐNT $1 \mathrm{~m})$ có 
kích thước LHĐ lớn nhất là $964 \mu \mathrm{m}$. Nhóm có thi lực từ $\geq 20 / 400-<20 / 100(51,9 \%)$ và từ ĐNT $1 \mathrm{~m}-<20 / 400(44,3 \%)$ có kích thước LHĐ trung bình lân lượt là 635,4 và $761,6 \mu \mathrm{m}$. Như vậy, kích thước î̃̂ hoàng điểm có liên quan tới kết quả thị lực sau phẫu thuật. Lỗ hoàng điểm lớn thì kết quả thị lực sau phấu thuật thấp hơn. Khác biệt có ý nghĩa thống kê với $p=0,009$. Khảo sát các yếu tố khác không thấy sự ảnh hưởng có ý nghĩa thống kê đến kết quả thị lực sau phẫu thuật $(0<0,05)$.

\section{BÀN LUÂN}

Nghiên cứu của chúng tôi gồm 52 mắt bong võng mạc do lỗ hoàng điểm được phẫu thuật cắt dịch kính, bóc màng ngăn trong, bơm khí nở hoặc dâuu silicon nội nhãn tại Bệnh viện Mắt Trung ương. Kết quả cho thấy tỷ lệ võng mạc áp sau lần mổ đầu là $80,8 \%$. Chỉ có 10 trường hợp $(19,2 \%)$ bong tái phát được phẫu thuật lần 2 và bơm dầu nội nhãn. ở các bệnh nhân này võng mạc đều áp sau khi tháo dầu. Có $61,5 \%$ đóng lỗ hoàng điểm sau mổ. Các kết quả này khá tương đồng với nghiên cứu của Nishimura (92\%; 55\%), Kakinoki $(85 \% ; 53,5 \%)$ và $\operatorname{Lim}(86 \% ; 52 \%)$ $[3 ; 4 ; 5]$. Thị lực trung bình tăng từ 1,99 $\pm 0,31$ logMAR lên 1,35 $\pm 0,26$ logMAR ở lần khám sau cùng.

Nhóm bệnh nhân có thời gian mắc bệnh ngắn hơn 6 tháng có tỷ lệ áp lại võng mạc là 38/47 mắt $(80,9 \%)$ và tỷ lệ đóng lỗ hoàng điểm là $31 / 47$ mắt (66\%), cao hơn đáng kể so với nhóm có thời gian bị bệnh dài hơn, với tỷ lệ tương ứng là $80 \%$ và $20 \%$. Như vậy, thời gian xuất hiện bệnh ngắn hơn thì tỷ lệ võng mạc áp và đóng lỗ hoàng điểm cao hơn ( $p$ lần lượt là 0,04 và $0,045)$, tương tự kết quả của Lam và cộng sư (2006) [6]. Bệnh càng kéo dài thì kích thước lố hoàng điểm càng lớn kèm theo thời gian bong võng mạc càng lâu thì càng gây tổn hại lớp biểu mô sắc tố vốn đã teo ở mắt cận thị nên hạn chế khả năng đóng lỗ và áp lại võng mạc. Vì vậy, phát hiện bệnh sớm và điêu trị kịp thời rất quan trọng để đảm bảo thành công của phẫu thuật.

Thị lực ban đâu có liên quan tới kêt quả giải phẫu của phẫu thuật. Thi lực càng kém thì khả năng áp võng mạc và đóng lỗ hoàng điểm sau mổ càng thấp ( $p$ lần lượt là 0,047 và 0,0084 ). Thị lực ban đâu là hậu quả của bệnh trên chức năng của mắt, do ảnh hưởng của những tổn hại về giải phẫu như dịch kính, võng mạc, cùng với các bệnh lý tồn tại sẵn có như đục thể thủy tinh, giãn phình củng mạc, mắt cận thị cao có teo hắc võng mạc. Thị lực ban đầu kém hơn biểu hiện các tổn hại nhãn cầu nặng hơn, nên khả năng phục hồi sau phẫu thuật han chế hơn. Nhiều nghiên cứu cũng chỉ ra mối liên quan này và coi thị lực trước phầu thuật là yếu tố tiên lượng cho kểt quả giải phẫu.

Nakanishi khảo sát các yếu tố tiên lượng áp võng mạc sau phẫu thuật cắt dịch kính và bơm khí nở nội nhãn ở bệnh nhân bong võng mạc do Iỗ hoàng điểm, nhân thấy trục nhãn cầu là một yếu tố tiên lượng cho việc dính lại của võng mạc [7]. Ở mắt có trục nhãn câuu dài hơn, củng mạc kéo dài ra phía sau hơn, dẫn đến lực kéo theo hướng ngược lại lên võng mạc manh hơn. Măc dù phẫu thuât loai bỏ màng dịch kính trước hoàng điểm làm giảm lực kéo theo phương tiếp tuyến lên võng mạc, nhưng nó có thể không đủ so với lực kéo ngược manh hơn trong mắt có trục nhãn cầu dài hơn. Trong nghiên cứu của chúng tôi bong võng mạc tái phát chỉ gặp ở những mắt có trục nhãn câu dài hơn $26 \mathrm{~mm}$ (10/45 mắt; $22,2 \%)$ mà không thấy ở những mắt có trục nhãn cầu ngắn hơn và khác biêt này có ý nghĩa thống kê $(p=0,038)$. Kết quả này cũng tương tự như trong nghiên cứu của Lam và cộng sự [6]. Tác giả lý giải rằng ở mắt có trục nhãn cầu dài, võng mạc hậu cực có thể không đủ so với chiếu dài phía sau của củng mạc, dẫn đến không cân xứng giữa các mô này. Khi phần võng mạc bị bong và thiếu tương đối này bị ép vào thành sau bởi chất đôn, võng mac, đặc biệt là vùng quanh lỗ hoàng điểm, có thể bị kéo căng ly tâm, ngăn chặn khả năng áp võng mạc và đóng lố hoàng điểm. Một số tác giả nhận thây trục nhãn câu không liên quan tới kết quả giải phẫu của lỗ hoàng điểm [6] nhưng trong nghiên cứu của chúng tôi, nhóm trục nhãn cầu dài có tỷ lệ đóng lỗ hoàng điểm sau phẫu thuật thấp hơn ( $p=0,032)$. Nghiên cứu của Ghoraba và cộng sự (2014) đã chỉ ra yếu tố nguy cơ của bong võng mạc tái phát sau phẫu thuật điều trị bong võng mạc do lỗ hoàng điểm là cận thi cao và giãn phình hậu cực [8]. Chúng tôi nhận thấy rằng tất cả mắt bong võng mạc tái phát đều là mắt cận cao (trên 12 đi-ốp) và giãn phình hậu cực, các mắt không giãn phình hậu cực võng mạc đều áp. Tỷ lệ đóng lố hoàng điểm cũng cao hơn ở những mắt không có giãn phình hậu cực $(p=0,015)$. Như vậy, chiều dài trục nhãn cầu và giãn phình hậu cực là một yếu tố quan trọng trong tiên lượng phẫu thuật cắt dich kính điêu trị bong võng mạc do lỗ hoàng điểm.

Trong nghiên cứu này, các mắt có lỗ hoàng điểm nhỏ hơn thì tỷ lệ bong võng mạc tái phát thấp hơn và khả năng đóng lỗ hoàng điểm cao hơn ( $p$ lần lượt là 0,038 và 0,013 ). Lỗ có kích 
thước nhỏ hơn $600 \mu m$ không có bong võng mạc tái phát và lỗ dưới $400 \mu m$ đều đóng hoàn toàn sau phẫu thuật. Xie và Lei (2013) cũng đưa ra kết luận tương tự khi cho rằng lỗ hoàng điểm lớn là yếu tố nguy cơ của bong võng mạc tái phát [9].

Nghiên cứu của chúng tôi không thấy sự khác biệt có ý nghĩa thống kê giữa mức độ bong võng mạc và tỷ lệ áp võng mạc sau phẫu thuật ( $p=$ 0,351 ). Tỷ lể này ở nhóm bong võng mạc khu trú hậu cực là 84,6\%, nhóm bong hậu cực và một góc phần tư và hai góc phần tư lần lượt là $62,5 \%$ và $80 \%$. Tuy nhiên, diện tích bong võng mạc có ảnh hưởng tới khả năng đóng lỗ hoàng điểm. Bong võng mạc càng rộng thì khả năng đóng lỗ hoàng điểm càng thấp $(p=0,04)$. Nhóm bong võng mạc rộng gồm hậu cực và một đến hai góc phần tư chỉ có tỷ lệ đóng LHĐ là $25 \%$ và $60 \%$ tương ứng, trong khi tỷ lệ này ở nhóm chỉ bong hậu cực là $69,2 \%$. Tuy nhiên nghiên cứu của Nakanishi và cộng sự không nhận thấy mối liên quan này [7].

Trong số 13 bệnh nhân được sử dụng khí nở C3F8 có 7 bệnh nhân có bong võng mạc tái phát cần can thiệp lại bơm dâu silicon nội nhãn $(53,8 \%)$. Tỷ lệ áp của võng mạc sau phẩu thuật cắt dịch kính bơm khí nở nội nhãn được báo cáo trong các nghiên cứu trước đây là $50-91 \%[4 ; 7]$. Nghiên cứu của chúng tôi tỉ lệ thành công áp lại võng mạc sau phẫu thuật lần đâu thấp hơn với tỉ lệ thành công $46,2 \%$. Tỷ lệ áp lại của võng mạc sau phẫu thuật cắt dịch kính với khí nở nội nhã̉n trong nhiều nghiên cứu được báo cáo là không khả quan, bệnh nhân sau đó cần phẫu thuật lại nhiều lần. Tác giả nhấn mạnh rằng thị lực sau phẫu thuật có liên quan chặt chẽ với khả năng áp lại của võng mạc ngay sau phẫu thuật vì càng thực hiện nhiều phẫu thuật bổ sung sau đó thì tiên lượing thị lực càng kém. Trong 39 bệnh nhân sử dụng dầu silicon nội nhãn, tỷ lệ áp võng mạc sau phẩu thuật là $92,3 \%$, tương đương với kết quả đã được Nishimura và cộng sự (92\%) [3]. Chúng tôi nhận thấy nhóm bệnh nhân có sử dụng dầu silicon nội nhãn có tỷ lệ bong võng mạc tái phát thấp hợn so với nhóm bệnh nhân sử dụng khí nở C3F8 $(p=0,001)$. Trong khi nghiên cứu của Kakinoki cho kết quả ngược lại với tỷ lệ áp ngay sau phẫu thuật của võng mạc với các mắt dùng khí nội nhãn là $91 \%$ so với dùng dầu chỉ là $73 \%$ [4]. Các tác giả khuyến cáo cân nhắc sử dụng dâu trên các mắt có tiên lượng kém như cận thị cao hoặc giãn phình hậu cực nhưng vẫn cần thêm các nghiên cứu so sánh.

Trong nghiên cứu của chúng tôi, kích thước lỗ hoàng điểm là yếu tố duy nhất ảnh hưởng tới kết quả thị lực sau phẫu thuât. Lỗ hoàng điểm lớn thì kết quả thị lực sau phẫu thuật thấp hơn $(p=$ 0,009 ). Liên quan của kích thước lỗ hoàng điểm trước phẫu thuật và kết quả thị lực sau phẫu thuật có thể do khả năng phục hồi về mặt giải phẫu ở các mắt có lỗ hoàng điểm lớn hợn thì kém hơn so với các mắt có lỗ hoàng điểm nhỏ. Chúng tôi cũng nhận thấy tỷ lệ đóng lỗ hoàng điểm và áp lại võng mạc ở các mắt có lỗ hoàng điểm nhỏ cao hơn có ý nghĩa thống kê so với các mắt có lỗ kích thước lớn ( $p$ lần lượt là 0,013 và 0,038). Nghiên cứu của Lam và cộng sự cũng nhận thấy rằng những mắt có thành công về mặt giải phẫu tốt hơn thì sự cải thiện chức năng cũng tốt hơn, cụ thể là thị lực chỉnh kính tối đa sau mổ ở nhóm bệnh nhân đóng lỗ hoàng điểm là 1,32 logMAR, cao hơn có ý nghĩa thống kê so với nhóm không đóng lỗ là 0,45 logMAR [6]. Ikuno cũng có kết luận tương tự và nhẩn mạnh đóng lỗ hoàng điểm là yếu tố quan trọng để cải thiện thị lực ở các mắt bong võng mạc do lỗ hoàng điểm [10]. Như vậy, việc đánh giá kích thước lỗ hoàng điểm trước phẫu thuật là một thao tác cần thiết để tiên lượng cho thành công của phẫu thuật cả về giải phẩu và chức năng.

Nghiên cứu của chúng tôi còn một số hạn chế. Thứ nhất, số lượng bệnh nhân còn ít cần tiếp tục nghiên cứu để có lượng bệnh nhân lớn hơn. Thứ hai, 6 tháng theo dõi sau mổ vẫn còn quá ngắn bởi bong võng mạc tái phát có thể xảy ra sau đó. Thứ ba, chúng tôi chỉ đánh thị lực trung tâm, những chức năng thị lực khác như thị trường chưa được đánh giá.

\section{KẾT LUẬN}

Phẫu thuật cắt dịch kính điêu trị bong võng mạc do lỗ hoàng điểm mang lại kết quả tốt về giải phẫu tuy nhiên kết quả thị lực còn thấp. Thời gian bị bệnh, thị lực ban đâu, trưc nhãn cầu, sự giãn phình hậu cực, kích thước lố hoàng điểm, mức độ bong võng mạc và chất độn nội nhãn là những yếu tố ảnh hưởng đến kết quả giải phẫu trong khi kích thước lỗ hoàng điểm ảnh hưởng đến kết quả thị lực của phẫu thuật.

\section{TÀl LIÊU THAM KHẢO}

1. Morita $\mathbf{H}$, Ideta $\mathbf{H}$, Ito $\mathbf{K}$, et al. Causative factors of retinal detachment in macular holes. Retina 1991;11:281-284

2. Gao $X$, Guo J, Meng $X$, et al. A meta-analysis of vitrectomy with or without internal limiting membrane peeling for macular hole retinal detachment in the highly myopic eyes. BMC Ophthalmol 2016;16:87

3. Nishimura A, Kimura M, Saito Y, Sugiyama K. Efficacy of Primary Silicone Oil Tamponade for the Treatment of Retinal Detachment Caused by 
Macular Hole in High Myopia. American Journal of Ophthalmology. 2011;151(1):148-155.

4. Kakinoki M, Araki T, Iwasaki $M$, et al. Surgical Outcomes of Vitrectomy for Macular Hole Retinal Detachment in Highly Myopic Eyes. Ophthalmology Retina. 2019;3(10):874-878.

5. Lim LS, Tsai A, Wong $D$, et al. Prognostic Factor Analysis of Vitrectomy for Retinal Detachment Associated with Myopic Macular Holes. Ophthalmology. 2014;121(1):305-310.

6. Lam RF, Lai WW, Cheung BTO, et al. Pars Plana Vitrectomy and Perfluoropropane (C3F8) Tamponade for Retinal Detachment Due to Myopic Macular Hole: A Prognostic Factor Analysis. American Journal of Ophthalmology. 2006;142(6):938-944.e2.

7. Nakanishi H, Kuriyama $S$, Saito $I$, et al. Prognostic Factor Analysis in Pars Plana Vitrectomy for Retinal Detachment Attributable to Macular
Hole in High Myopia: A Multicenter Study. American Journal of Ophthalmology. 2008;146(2):198-204.e1.

8. Ghoraba HH, Elgouhary SM, Mansour HO. Silicone Oil Reinjection without Macular Buckling for Treatment of Recurrent Myopic Macular Hole Retinal Detachment after Silicone Oil Removal. Journal of Ophthalmology. 2014;2014:1-5.

9. Xie A, Lei J. Pars Plana Vitrectomy and Silicone Oil Tamponade as a Primary Treatment for Retinal Detachment Caused by Macular Holes in Highly Myopic Eyes: A Risk-Factor Analysis. Current Eye Research. 2013;38(1):108-113.

10. Ikuno $Y$, Sayanagi $K$, Oshima $T$, et al. Optical coherence tomographic findings of macular holes and retinal detachment after vitrectomy in highly myopic eyes. American Journal of Ophthalmology. 2003;136(3):477-481.

\title{
SỰ HÀI LÒNG NGƯờI BÊNH VỀ GIAO TIẾP CỦA NGƯỜI ĐIỂU DƯỠNG
}

\author{
Nguyễn Thị Hoàng Yến*, Võ Hồng Khôi*, Nguyễn Ngọc Hòa**
}

\section{TÓM TẮT}

Đặt vấn đề: Nâng cao thái độ giao tiếp của điều dưỡng viên với bệnh nhân trong công tác chăm sóc điêuu trị phải luôn được chú trọng nhằm hướng tới sự hài lòng của người bệnh bởi những điều đó ảnh hưởng rất lớn tới chất lượng và hiêu quả chăm sóc. Vì vậy, nghiên cứu khảo sát mối liển quan giữa sự hài long của ngươoi bênh với giao tiếp của điều dướng viên là thực sự cần thiết. Mục tiêu: Đánh giá sự hài lòng của người bệnh về giao tiếp của người điều dưỡng tại Trung tâm Thần Kinh - Bệnh Viện Bạch Mai từ tháng 02/2021đến tháng 06/2021. Phướng pháp nghiên cứu: Nghiên cứu theo phương pháp mô tả cắt ngang trên 238 đối tượng được lựa chon ngấu nhiên. Dữ liệu được thu thập bởi bộ câu hỏi về sự hài lòng của bệnh nhẩn và sự giao tiếp của điêu dướng đã được tác giả Đinh Ngọc Thành xây dựng và tiển hành trên 197 bênh nhần nội trú tại Bênhi Viên A Thái Nguyên [1] với bố câu hỏi tự điền 36 câu của 2 bô câu hỏi trên 5 điểm của thang đo "Likert scale." Với bộ câu hỏi "Sự hài lòng của bệnh nhân với giao tiếp của điều dưỡng" điểm đánh giá từ 1 là rất không hài lòng đến 5 là rất hài lòng. Điểm cao chỉ ra mức đô hài lòng cao. Còn với bộ câu hỏi "Sự giao tiếp của điều dưỡng" điểm đánh giá từ 1 là khống bao giờ đến 5 là rất thường xuyên. Điểm cao chỉ ra mức độ cao về giao tiếp. Kết quả: Các đối tượng tham gia nghiên cứu có tuổi trung bình là $52,96 \pm 16,4$, nữ chiếm ưu thế $(51,3 \%)$, tỷ lệ kết

\section{*Bênh Viện Bach Mai}

**Bênh viện Hữu nghị Đa khoa Nghệ An

Chịu trách nhiệm chính: Nguyễn Ngọc Hòa

Email: tranxuanhoa0510@gmail.com

Ngày nhận bài: 15.6.2021

Ngày phản biên khoa hoc: 10.8.2021

Ngày duyệt bài: 17.8.2021 hôn đạt $(88 \%)$, tập trung nhiêu ở trình độ cấp II và cấp III $(45,8$ và $34,9 \%)$, đa số có BHYTं $(89,9 \%)$, ngày nằm viên trung bình là $5-10$ (48,3\%). Điểm trung bình sự hài lòng của người bệnh là $4,33 \pm 0,516$, điểm trung bình về sư giao tiếp của điều dưỡng: 4,20 $\pm 0,600$. Kết luận: Kết quả của nghiên cứu cho thấy người bệnh có sự hài lòng ở mức độ cao với giao tiếp của điều dưỡng. bệnh

Từ khóa: giao tiếp điều dưỡng, sự hài lòng người

\section{SUMMARY \\ ASSESSMENT OF PATIENT STATISFACTION FROM NURSE COMMUNICATION}

Background: Patient-nurse communication in healthcare was pivotal tool to assess patient satisfaction. Improving nurse communication contribute to patient satisfaction, hence increases quality and effectivenes of healthcare. The aim of this study to assess the association betweeen patient satisfaction and nurse communication. Objective: Assess patient satisfaction from patient-nurse communication at the Neurology Center of Bach Mai Hospital in 2021. Methods: Descriptive crosssectional design. 238 patients were randomly selected. Data based on 36-question self-completed questionnaire were collected. Results: The average age was $52.96 \pm 16.4$ years old, female $(51.3 \%)$, got married $(88 \%)$, have a secondary and high school level in educational stage (45.8 and $34.9 \%$, get health insurance $(89.9 \%)$, the average length of stay in hospital was $5-10$ days (48.3\%). The average score of patient satisfaction and nurse communication was $4.33 \pm 0.516$ and $4.20 \pm 0.600$, respectively. Conclusion: The results show that most patients were high satisfied level with nursing care. Keywords: nurse communication. patient satisfaction. 


\section{I. ĐĂT VẤN ĐỀ}

Trong bênh viên, bên canh bác sĩ thì điều dưỡng viên là người có nhiều thời gian tiếp xúc trực tiếp với bệnh nhân và người nhà người bệnh. Những hoạt động của đội ngũ điều dưỡng viên góp phần không nhỏ trong sự nghiệp chăm sóc và bảo vệ sức khỏe nhân dân.

Điêu dưỡng hàng ngày phải tiếp xúc và giao tiếp với người bệnh và người nhà người bệnh, điều đó đòi hỏi sự giao tiếp của điều dưỡng phải chuyên nghiệp, tận tâm và chu đáo. Nếu người điêu dưỡng giao tiếp tốt với người bệnh, thiết lập được mối quan hệ tin cậy, hợp tác với họ sẽ tạo được một môi trường tâm lý tích cực cho quá trình điều trị. Ngược lại, nếu quá trình giao tiếp của người điều dưỡng với người bệnh không đạt kết quả mong muốn sẽ có những ảnh hưởng tiêu cực đối với quá trình điều trị người bệnh, đồng thời ảnh hưởng đến uy tín của của người thây thuốc và bệnh viện nói riêng, ngành y tế nói chung. Vì vậy việc nâng cao thái độ giao tiếp của người điều dưỡng với người bênh trong công tác chăm sóc điều trị bệnh nhân phải luôn được chú trọng, hướng tới sự hài lòng của người bệnh. Tuy nhiên, công tác điều dưỡng tại các bệnh viện hiện nay còn nhiều bất cập như thiếu về số lượng, yếu về chất lượng, hệ thống đào tạo chưa thống nhất, các kỹ thuật thực hành chăm sóc chưa được chuẩn hóa, kỹ năng giao tiếp xã hội của người điều dưỡng chưa được chú trong đào tạo và rèn luyện. Những điều bất cập đó đôi khi ảnh hưởng rất lớn tới chất lượng và hiệu quả chăm sóc người bệnh, vì vậy nghiên cứu khảo sát mối liên quan giữa hài lòng người bênh và giao tiếp của điều dưỡng là thực sự cần thiết.

\section{II. ĐỐI TƯỢNG VÀ PHƯƠNG PHÁP NGHIÊN CỨU}

2.1. Thiết kế nghiên cứu: Nghiên cứu theo phương pháp mô tả cắt ngang có phân tích.

\subsection{Tiêu chuẩn lựa chọn.}

- Từ 18 tuổi trở lên.

- Biết nói, biết đọc, biết viết tiếng Viêt

- Là người bệnh đồng ý tham gia nghiên cứu.

2.3. Cỡ mấu và chọn mẫu: 238 đối tượng nghiên cứu đã được lựa chọn ngẫu nhiên. Dữ liệu đã được thu thập từ 01/02/2021đến 31/06/2021

\subsection{Công cụ nghiên cứu:}

Bộ câu hỏi nghiên cứu gồm 3 phần

Phần 1: Câu hỏi về các thông tin cơ bản.

Phần 2: Bộ câu hỏi sự hài lòng người bệnh về giao tiếp của điều dưỡng. dương

Phần 3: Bộ câu hỏi sự giao tiếp của điêu
2.5. Đạo đức nghiên cứu:

- Nghiển cứu được thông qua bởi Hội đồng nghiên cứu khoa học trường.

- Trước khi tiến hành nghiên cứu, đối tượng nghiên cứu được giải thích rõ về mục đích và nội dung của nghiển cứu trước khi tiến hành phỏng vấn và tiến hành khi có sự chấp nhận, hợp tác tham gia của đối tượng nghiên cứu, ý nghĩa của việc tham gia nghiên cứu.

- Nghiên cứu chỉ thực hiện với người bệnh tự nguyện tham gia, phiếu khảo sát được mã hóa đảm bảo giữ bí mật các thông tin, số liệu được thu thập đầy đủ, chính xác, trung thực, chỉ sử dụng cho mục đích nghiên cứu khoa học, không phục vụ cho mục đích nào khác.

\section{KẾT QUẢ NGHIÊN CỨU VÀ BÀN LUÂ̂N}

3.1 Đặc điểm chung của đối tượng nghiên cứu

\begin{tabular}{|c|c|c|}
\hline Đặc điểm & $\begin{array}{c}\text { Tân } \\
\text { số (n) }\end{array}$ & $\begin{array}{c}\text { Tỷ lệ̂ } \\
(\mathbf{\%})\end{array}$ \\
\hline Nhóm tuối: $<30$ & 22 & 9,2 \\
\hline $30-39$ & 32 & 13,5 \\
\hline $40-49$ & 40 & 16,8 \\
\hline$>=50$ & 144 & 60,5 \\
\hline Tuối trung bình & \multicolumn{2}{|c|}{$52,96 \pm 16,4$} \\
\hline
\end{tabular}

\begin{tabular}{|lll|l|}
\hline Giới tính: & Nam & 116 & 48,7 \\
\hline & Nữ & 122 & 51,3 \\
\hline
\end{tabular}

Tình trạng hôn nhân

\begin{tabular}{|c|c|c|}
\hline Chưa kết hôn & 22 & 9,5 \\
\hline Đã kết hôn & 210 & 88 \\
\hline Góa/ly hôn/ly thân & 6 & 2,5 \\
\hline \multicolumn{3}{|l|}{ Trình độ học vấn } \\
\hline Cấp 1 & 20 & 8,4 \\
\hline Cấp 2 & 109 & 45,8 \\
\hline Cấp 3 & 83 & 34,9 \\
\hline Đai hoc/ Cao đắng & 22 & 9,2 \\
\hline Trên Đại học & 4 & 1,7 \\
\hline BHYT: Không BHYT & 24 & 10,1 \\
\hline BHYT & 214 & 89,9 \\
\hline Ngày năm viện: < 5 ngày & 92 & $\begin{array}{l}38,7 \\
38.7\end{array}$ \\
\hline 5- 10 ngày & 115 & 48,3 \\
\hline$>10$ ngày & 31 & 13 \\
\hline Trung bình số ngày NV & \multicolumn{2}{|c|}{$6,24 \pm 3,60$} \\
\hline
\end{tabular}

Các đối tượng tham gia nghiên cứu có tuổi trung bình là $52,96 \pm 16,4$. Đa số người bệnh nội trú có độ tuổi từ 50 trở lên với tỷ lệ $(60,5 \%)$. Không có sự chênh lệch đáng kể giữa tỷ lệ nam $(48,7 \%)$ và nữ $(51,3 \%)$. Đối tượng đã kểt hôn chiếm tỷ lệ lớn $(88 \%)$, Trình độ học vấn trung nhiều ở trình độ cấp 2 và cấp 3 chiếm $(45,8)$ và $(34,9 \%)$. Số người bênh điêu tri nội trú taii khoa thân kinh đa phần là có thẻ BHYT chiếm 89,9\%, thời gian nằm viện viện từ $5-10$ ngày chiếm tỷ lế nhiều nhất $(48,3 \%)$. 
3.2 Mức độ hài lòng của người bênh

\begin{tabular}{|c|c|c|}
\hline $\begin{array}{l}\text { Các khía canh giao tiếp } \\
\text { của điểu dướng }\end{array}$ & $\begin{array}{c}\text { Trung } \\
\text { bình }\end{array}$ & $\begin{array}{l}\text { Giải } \\
\text { thích } \\
\text { điểm }\end{array}$ \\
\hline $\begin{array}{l}\text { Mức độ hài lòng chung } \\
\text { của NB }\end{array}$ & $\begin{array}{c}4,33 \pm \\
0,516\end{array}$ & Cao \\
\hline Biện hộ cho NB & $\begin{array}{c}4,34 \pm \\
0,498\end{array}$ & Cao \\
\hline $\begin{array}{l}\text { Biếu lộ hành vi khi } \\
\text { phản hồi thông tin }\end{array}$ & $\begin{array}{r}4,27 \pm \\
0,465 \\
\end{array}$ & Cao \\
\hline Cho NB lời chỉ dẫn rõ ràng & $\begin{array}{c}4,29 \pm \\
0,473\end{array}$ & Cao \\
\hline Hỏi các quyết định điêu trị & $\begin{array}{c}4,36 \pm \\
0,490 \\
\end{array}$ & Cao \\
\hline $\begin{array}{c}\text { Đề nghị tư vấn khi có nhu } \\
\text { cầu }\end{array}$ & $\begin{array}{c}4,39 \pm \\
0,530 \\
\end{array}$ & Cao \\
\hline $\begin{array}{l}\text { Phát biếu có tính nhất } \\
\text { quán các thông tin }\end{array}$ & $\begin{array}{c}4,38 \pm \\
0,511\end{array}$ & Cao \\
\hline $\begin{array}{l}\text { Hướng dân các hoạt động } \\
\text { chăm sóc phòng bệnh }\end{array}$ & $\begin{array}{c}4,38 \pm \\
0,536 \\
\end{array}$ & Cao \\
\hline $\begin{array}{l}\text { Chuấn bị NB cho các thủ } \\
\text { thuật }\end{array}$ & $\begin{array}{c}4,39 \pm \\
0,506\end{array}$ & Cao \\
\hline Giải thích lựa chọn điều trị & $\begin{array}{c}4,29 \pm \\
0,473\end{array}$ & Cao \\
\hline $\begin{array}{l}\text { Sử dưng giao tiếp chữa } \\
\text { bệnh của điều dưỡng }\end{array}$ & $\begin{array}{c}4,32 \\
\pm 0,535 \\
\end{array}$ & Cao \\
\hline Duy trì khoảng cách & $\begin{array}{r}4,26 \pm \\
0,527\end{array}$ & Cao \\
\hline Thể hiện nét mặt & $\begin{array}{c}4,29 \pm \\
0,541\end{array}$ & Cao \\
\hline Sử dụng ánh mắt & $\begin{array}{c}4,35 \pm \\
0,536 \\
\end{array}$ & Cao \\
\hline $\begin{array}{c}\text { Cho phép NB thế hiện điều } \\
\text { họ không vừa ý }\end{array}$ & $\begin{array}{c}4,35 \pm \\
0,536\end{array}$ & Cao \\
\hline $\begin{array}{c}\text { Thừa nhận các vấn đề NB } \\
\text { quan tâm }\end{array}$ & $\begin{array}{r}4,34 \pm \\
0,564 \\
\end{array}$ & Cao \\
\hline $\begin{array}{c}\text { Sư dụng thời gian cho vấn } \\
\text { đề NB quan tâm }\end{array}$ & $\begin{array}{c}4,37 \pm \\
0,508\end{array}$ & Cao \\
\hline Tính giá trị & $\begin{array}{r}4,34 \pm \\
0,523\end{array}$ & Cao \\
\hline Hỏi để làm rõ vấn đề & $\begin{array}{r}4,32 \pm \\
0,517 \\
\end{array}$ & Cao \\
\hline Sử dụng câu hỏi rõ ràng & $\begin{array}{c}4,34 \pm \\
0,532 \\
\end{array}$ & Cao \\
\hline $\begin{array}{l}\text { Hỏi đế kiếm tra nhận thức } \\
\text { của NB }\end{array}$ & $\begin{array}{r}4,34 \pm \\
0,517 \\
\end{array}$ & Cao \\
\hline $\begin{array}{l}\text { Cung cấp thông tin } \\
\text { phản hồi chi tiết }\end{array}$ & $\begin{array}{r}4,34 \pm \\
0,527 \\
\end{array}$ & Cao \\
\hline
\end{tabular}

Nhìn chung người bệnh đều có mức độ hài lòng cao với cả 3 khía cạnh của giao tiếp đó là "Các yễu tố biện hộ" $(=4,34, \mathrm{SD}=.50)$ "việc sử dụng chữa bệnh bằng giao tiếp của điều dưỡng" $(=4,32, \mathrm{SD}=.53)$, và "Các yếu tố giá trị" $(=4,34$, $\mathrm{SD}=.52)$. Có nhiều yếu tố ảnh hưởng đến kết quả trên. Trước hết, có thể thấy điều dưỡng tại
Trung tâm Thần kinh đã thực hiện tốt tất cả các khía cạnh của giao tiếp. Việc truyền tải những thông tin cần thiết một cách hiệu quả khiến những phản hồi từ người bệnh đên giao tiếp của điều dưỡng viên đa phần là tích cực. Hơn nữa, vấn đề văn hóa cũng có thể ảnh hưởng đến điểm hài lòng bởi vì người dân Việt Nam thường rất tôn trọng nghề chăm sóc sức khỏe họ coi nghề này là một nghề cao quý nên sẽ có cách tiếp nhận thông tin bao dung hơn. (theo Ozsoy và cộng sự (2007)[2]

Theo nghiên cứu của chúng tôi, tỷ lệ hài lòng chung về giao tiếp của điều dưỡng đạt 4,33 $(86,6 \%)$ cao hơn so với nghiên cứu của Đinh Ngọc Thành $(3,83$ tương đương $76,6 \%)[1]$ và Nguyễn Đức Thành[3]. Tuy nhiên, con số này thấp hơn so với nghiên cứu của Hà Thị Soạn $(90,3 \%)[4]$ và Hoàng Đoan Trang (từ 90,2\% 94,5\%)[5] Sự khác biệt này có thể giải thích do bên cạnh những nhân viên y tế có thái độ hòa nhã, hướng dẫn nhiêt tình với người bênh thì vẫn có những nhân viên biểu lộ thái độ không vui vẻ, sử dụng từ ngữ giao tiếp với người bệnh chưa đúng mực, không hướng dẫn hoặc hướng dẫn không rõ ràng [3].

Kết quả nghiên cứu của chúng tôi cho thấy tỷ lệ hài lòng về công tác hướng dần chăm sóc và phòng bệnh đạt $87,6 \%$. Kết quả này phù hợp với nghiên cứu Nguyễn Ngọc Phước $(90,3 \%)$ [6] và Đào Thanh Lam $(87,7 \%)$ [7]. Trong các khía cạnh đánh giá sư hài lòng của người bệnh thì lĩnh vực hướng dẩn chăm sóc và phòng bềnh của người điều dưỡng rất quan trong vì hầu hết thời gian tiếp xúc và giao tiếp giữa điều dưỡng và người bệnh là thông qua các hoạt động chăm sóc hàng ngày. Do vậy, thời gian nằm viện dài hay ngắn, thời gian tiếp xúc và giao tiếp của người bệnh và điêu dưỡng nhiều hay ít cũng ảnh hưởng không nhỏ đến việc đánh giá sự hài lòng của người bềnh.

Giải thích cho sự khác biệt trong kết quả nghiên cứu của tôi so với kết quả nghiên cứu của một số tác giả kể trên có thể xuất phát từ các đặc điểm của đối tượng nghiên cứu và địa bàn nghiên cứu, bệnh viện trực thuộc tuyến trung ương phần nào đó có thể có phong cách làm việc, ứng xử và giao tiếp chuyên nghiệp hơn so với các bệnh viện trực thuộc các tuyến địa phương. Ngược lại, đôi khi các bệnh viện tuyển trên gặp phải tình trạng quá tải, số lượng người bênh đến sử dụng dịch vụ quá đông cũng có thê̂ dẩn đến các áp lực trong công việc và ảnh hưởng không nhỏ đến việc thực hiện ứng xử và giao tiếp. 


\section{KẾT LUẬN}

Kết quả của nghiên cứu đã cho thây mức độ hài lòng chung của người bệnh nội trú tại Trung tâm Thần kinh Bệnh Viện Bạch Mai với giao tiếp của điều dưỡng là cao. Sự hài lòng của người bệnh là một tiêu chí có ý nghĩa trong đánh giá chất lượng của chăm sóc điêuu dưỡng, Để nâng cao sự hài lòng của người bệnh cũng như đảm bảo chất lượng trong chăm sóc điêu dưỡng thì các kỹ năng giao tiếp điều dưỡng nên được đào tạo một cách hợp lý.

\section{TÀI LIÊU THAM KHẢO}

1. Thành, Đ.N., Mối liên quan giữa giao tiếp của điều dưỡng và sự hài lòng người bệnh của bệnh nhân nội trú tại bệnh viện a thái nguyên Tạp chí khoa học và cống nighệ $8 \dot{9}(01) / 1,2011$.

2. Ozsoy, S.A., Ozgur G. \& Akyol, D, Patient expectations and Satisfaction with nursing care in
Turkey: A Literature review. International. Nursing Review, 24, 2007.

3. Thành, N.Đ., Sư hài lòng của người bênh nôi trú về chất lượng chăm sóc sức khỏe tai các bệnh viện tỉnh Hòa Bình Nghiên cứu đề tài cấp cơ sở Trường Đại học y tế công cộng Hà Nôi 2006.

4. Soạn, H.T., Đánh giá sự hài lòng của người bệnh và người nhà người bệnh đối với công tác KCB tại một số bệnh viện tại phú tho Kỷ yểu các đề tài nghiên cứu khoa học điêu dưỡng . Hội nghị khoa học điều dưỡng lần thứ III, 2007.

5. Trang, H.Đ., "Đánh giá sự hài lòng của người bênh tại khoa Khám bênh bệnh viện Bạch Mai. luận vắn tốt nghiệp Đaii học Thăng Long Hà Nội, 2010.

6. Phước, N.N.., Đánh giá sự hài lòng của người bệnh nội trú và người nhà người bệnh về chất lượng dịch vụ y tế taii viện Tim mạch - Bệnh Viện Bạch Mai Hà Nội 2014.

7. Lam, Đ.T., Khảo Sát Sự Hài Lòng của người bệnh về dịch vư chăm sóc điêu dưỡng tại Bệnh viện $Y$ học cổ truyền Trung ương. khóa luận tốt nghiệp cử nhân Y khoa Đại học Y Hà Nội 2016.

\title{
THỰC TRANG MẮC BÊNNH BỤI PHỔI THAN CỦA NGƯờI LAO ĐộNG TẠI CÔNG TY CỔ PHẦn THAN VÀNG ANH, QUẢNG NINH NĂM 2021
}

\author{
Khương Văn Duy'1, Nguyễn Thị Quỳnh' ${ }^{1}$, \\ Khương Phương Thủy ${ }^{2}$, Đặng Thị Trang ${ }^{1}$, Nguyễn Thanh Thảo

\section{VANG DANH COAL JOINT STOCK} \\ COMPANY, QUANG NINH IN 2021 \\ Objective: The study aimed to describe the
}

\section{TÓM TẮT}

Mục tiêu: xác định tỷ lệ hiện mắc bệnh bụi than của người lao động tại Công ty cổ phân than Vàng Danh, Quảng Ninh năm 2021. Phương pháp nghiên cứu: nghiên cứu cắt ngang trên 1992 người lao đông tiếp xúc trực tiếp với bụi than tại Công ty cổ phần than Vàng Danh, Quảng Ninh năm 2021. Kết quả: tỷ lê mắc bệnh bụi than chiếm 15,8\%, trong đó thể biến chứng là $2,9 \%$. Tỷ lệ mắc bênh bui phổi than ở nam giới là $16,2 \%$, hơn một nửa $(56,6 \%)$ người mắc bệnh ở nhóm tuổi 30-39, nhóm tuổi nghề có tỷ lệ mắc bệnh cao nhất là 11-15 năm. Đa số đám mớ nhỏ có kích thước $p / p(85,1 \%)$ và mật độ tổn thương ở nhóm 1 $(60,6 \%)$. Kết luận: phần lớn đối tượng nghiên cứu không mắc bệnh bụi phổi than. Trong nhóm mắc bệnh bụi phổi than hầu hết là thể đơn thuần.

Tư khóa: thực trạng mắc bệnh, bệnh bụi phổi than, Công ty cổ phần than Vàng Danh

\section{SUMMARY}

\section{THE PREVALENCE OF OF COAL WORKERS'} PNEUMOCONIOSIS AMONG WORKERS AT

\author{
${ }^{1}$ Viện Đào tạo Y học dự phòng và Y tế công cộng, \\ trường Đại hoc Y Hà Nội \\ 2Trương đại hoc RMIT, Australia \\ Chịu trách nhiệm chính: Khương Văn Duy \\ Email: nguyenthiquynhhmu@gmail.com \\ Ngày nhận bài: 24.6.2021 \\ Ngày phản biên khoa hoc: 17.8.2021 \\ Ngày duyệt bài: 25.8.2021
} prevalence of coal workers' pneumoconiosis among workers at Vang Danh Coal Joint Stock Company, Quang Ninh in 2021. Methods: a cross-sectional study on 1992 workers exposed directly to coal dust at Vang Danh Coal Joint Stock Company, Quang Ninh in 2021. Results: The prevalence of coal workers pneumoconiosis was $15.8 \%$, in which, progressive massive fibrosis was $2.9 \%$, male rate was $16.2 \%$, more than a half $(56.6 \%)$ of those from 30 to 39 year olds and the work experience from 11 to 15 years was the highest rate. The majority of lesions with small opacity size was $\mathrm{p} / \mathrm{p}(85.1 \%)$ and small opacities density in category 1 (60.6\%). Conclusion: Most workers did not suffer from coal workers' pneumoconiosis, most of them were mild.

Keyworks: prevalence, coal wokers' pneumoconiosis, Vang Danh Coal Joint Stock Company

\section{I. ĐẶT VẤN ĐỀ}

Ngành khai thác than đóng vai trò quan trọng trong nền kinh tế quốc dân ở Việt Nam và tạo công ăn việc làm cho nhiều người lao động. Tuy nhiên khai thác than là ngành lao động nặng nhọc luôn chứa đựng các yếu tố nguy hiểm và độc hại cho người lao động như trớn trượt, sập hẩm lò và nguy cơ mắc bệnh bụi phổi than. Bệnh bụi phổi than là một bệnh nghề nghiệp xuất hiện ở những người lao động tiếp xúc với bụi than, 
tuy nhiên bênh hiện chưa có thuốc điều trị đăc hiệu. Bệnh do phản ứng của tổ chức phổi do hít thở cộng dồn bụi than vào trong phổi phát triển chậm và đặc trưng bởi tình trang xơ hóa phổi không hồi phục và có thể dẫn đến các biến chứng nguy hiểm như bệnh phổi tắc nghẽn mạn tính, tâm phế mạn, gây tổn hại nghiêm trọng đến sức khỏe, khả năng lao động và kinh tế 1 .

Hiện nay các bệnh nghề nghiệp như bệnh bụi phổi silic, bệnh bụi phổi than ngày càng được quan tâm, các nghiên cứu cũng được thực hiện nhiều hơn. Năm 2013, tại Trung Quốc tỷ lệ mắc bênh bự phổi ở công nhẩn khai thác than hầm lò là $31,8 \%$, khai thác than lộ thiên $27,5 \%$, công nhân vừa khai thác hầm lò và lộ thiên tỷ lệ mắc là $24,2 \%$ và làm công việc hỗ trợ người khai thác than là 2,6\%2ㄹ tại Mỹ (2010) nguy cơ mắc bệnh bụi phổi ở công nhân khai thác than hầm lò chiếm tới $48 \%^{3}$. Tại Việt Nam đã có một số nghiên cứu đánh giá thực trạng mắc bệnh bụi phổi than như tỷ lê mắc tại mỏ đá Núi Hồng, Thái Nguyên là $40 \%{ }^{4}$, tại Công ty cổ phần than Tây Nam đá mài là $28,5 \%{ }^{5}$. Tuy nhiên các nghiên cứu về bệnh bụi phổi than vẫn còn hạn chế. Mă̆t khác, ở nước ta đã triển khai chương trình "phòng chống và loại trừ bệnh bụi phổi silic" cần thiết phải triển khai tiếp chương trình phòng chống và loại trừ bệnh bụi phổi than nhằm cải thiện chất lượng của sống cho người lao động tiếp xúc với bụi than và gia đình họ, cũng như cải thiện năng lực cạnh tranh giữa các công ty khai thác than. Do chúng tôi tiến hành nghiên cứu với đề tài: "Thực trang mắc bênh bụi phổi than của người lao động tại Công ty cổ phần than Vàng Danh, Quảng Ninh năm 2021", với muc tiêu: xác định tỷ lệ hiện hiên mắc bênh bui than của người lao động tại Công ty cổ phần than Vàng Danh, Quảng Ninh năm 2021.

\section{II. ĐỐl TƯƠNG VÀ PHƯƠNG PHÁP NGHIÊN CỨU}

2.1. Đối tượng nghiên cứu: Người lao động đang làm việc tại Công ty cổ phần than Vàng Danh từ tháng 10 năm 2020 đến 31 tháng 5 năm 2021 và tiếp xúc trực tiếp với bụi than.

\section{* Tiêu chuân lưa chon}

- Người lao động đã làm việc tại các Công ty thời gian từ 1 năm trở lên.

- Trước đây đã từng làm công tác trực tiếp tiếp xúc với bụi than nhưng hiện tại làm cổng tác quản lý.

- Đồng ý tham gia nghiên cứu.

- Chất lượng phim chụp bụi phổi theo phân loại của ILO - 2000, ILO - 2011 đạt từ loại 1 đến loại 3.

\section{* Tiêu chuẩn loai trừ}

- Lao động hợp đồng theo thời vụ.

- Có thầm niên nghề nghiệp dưới 1 năm.

- Không đồng ý tham gia nghiên cứu.

- Chất lượng phim chụp lồng ngực loại 4 (theo hướng dẫn sử dụng bảng phân loại quốc tế ILO - 2000 phim XQ các bệnh bụi phổi).

2.2. Địa điểm nghiên cứu: Công ty cổ phần than Vàng Danh, tỉnh Quảng Ninh.

2.3. Thời gian nghiên cứu: Nghiên cứu tiến hành từ tháng 10/2020 đến 31 tháng 5/2021.

\subsection{Phương pháp nghiên cứu}

* Thiết kế nghiên cứu: Thiết kế nghiên cứu áp dụng trong đề tài này là mô tả cắt ngang

* Cõ mẫu và kỹ thuật chọn mẫu nghiên cứu

- Toàn bộ người lao động thuộc công ty than Vàng Danh đủ tiêu chuẩn lựa chọn được chon vào nghiên cứu. Các đối tượng được phỏng vấn, khám sức khỏe và chụp Xquang phim lồng ngực kỹ thuật số. Do có một số đối tượng vắng mặt, và chất lượng phim lồng ngực không đạt, thực chất còn 1992 đối tượng tham gia nghiên cứu.

\section{* Biến số và chỉ số nghiên cứu}

Biến số độc lập: giới, tuổi đời, tuổi nghề, mật độ đám mờ nhỏ, một độ đám mờ lớn, kích thước đám mờ lớn.

- Biến số phụ thuộc: mắc bệnh bụi phổi than theo giới, tuổi đời, tuổi nghề

\section{* Công cu thu thâp thông tin}

- Bộ câu hỏi nghiên cứu: nội dung bô câu hỏi xây dựng dựa trên mục tiêu và các biến số, chỉ số nghiên cứu

- Khám lâm sàng và chụp phim $X$ quang: tổn thương đám mờ nhỏ, đám mờ lớn, mât độ đám mờ... theo phiếu đọc phim bụi phổi của ILO - 2000.

\section{* Kỹ thuật thu thập thông tin}

- Số liệu được thu thập trực tiếp bằng phương pháp phỏng vấn để thu thập các thông tin chung của đối tượng nghiên cứu

- Khám lâm sàng và chụp phim $X$ quang bụi phổi $35 \times 43 \mathrm{~cm}$ và đọc phim Xquang bui phổi theo tiêu chuẩn ILO - 2000 để chẩn đoán tình trạng mắc bệnh bụi phổi than.

\section{* Quản lý và xứ lý thông tin:}

- Số liệu sau khi thu thập xong được làm sach ngay, loại đi các phiếu khồng đủ tiêu chuẩn, sau đó được nhập liệu bằng phần mềm EPIDATA 3.1 và chuyển sang phần mêm SPSS 20.0 để phân tích để cho ra các bảng tần số về thông tin chung, mật độ và kích thước đám mờ nhỏ, tỷ lệ mắc bệnh bụi phổi than theo tuổi, giới, tuổi nghề.

\subsection{Sai số và khống chế sai số}

- Sai số hệ thống: sai số nhớ lại, để hạn chế sai số này bộ câu hỏi nghiên cứu thiết kể trước khi điều tra đối tượng phải được hỏi thử và chỉnh 
sửa phù hợp với ngôn từ, ngắn gọn giúp đối tượng điều tra trả lời chính xác. Điêu tra viên phải được tập huấn trước khi tiến hành nghiên cứu, đảm bảo hiểu rõ phiếu nghiên cứu, ngôn ngữ linh hoạt.

- Sai số nhập số liệu: 2 người nhập liệu trong đó 1 người đọc phiếu, một người vào máy tính. Vừa nhập số liệu vừa kiểm tra độ chính xác của nhập sổ liệu và kiểm tra lại số liệu đã nhập một lần nữa để tránh sai sót. Sau khi kiểm tra xong phần nhập liệu, bộ số liệu sẽ chuyển sang phần mềm SPSS 22.0 để phân tích.

2.6. Đạo đức nghiên cứu. Nghiên cứu được Hội đồng phê duyệt đề tài thông qua $(\mathrm{Q} Đ$ số 616/QĐ-ĐHYHN, ngày 2 tháng 4 năm 2021) và được sự cho phép của Tập đoàn Công nghiệp Than Khoáng Việt Nam. Đối tượng nghiên cứu có thể từ chối tham gia nghiên cứu ở bất kỳ thời điểm nào của nghiên cứu. Mọi thông tin cá nhân đều được giữ bí mật và chỉ sử dụng vào mục đích nghiên cứu.

\section{KẾT QUẢ NGHIÊN CỨU}

Bảng 1. Một số đặc điểm chung của đôi tượng nghiên cứu

\begin{tabular}{|c|c|c|}
\hline Đặc điểm & Số lượng & Tỷ lệ (\%) \\
\hline Giới tính: Nam & 1940 & 97,4 \\
\hline Nữ & 52 & 2,6 \\
\hline
\end{tabular}

\begin{tabular}{|c|c|c|}
\hline \multicolumn{3}{|c|}{ Nhóm tuối đời (tuối) } \\
\hline$<30$ & 226 & 11,3 \\
\hline $30-39$ & 1128 & 56,6 \\
\hline $40-49$ & 514 & 25,8 \\
\hline$\geq 50$ & 124 & 6,2 \\
\hline Tuối đời (tuối) & \multirow{2}{*}{\multicolumn{2}{|c|}{$\frac{\text { Trung bình } \pm \text { SD }}{37,3 \pm 6.8}$}} \\
\hline & & \\
\hline \multicolumn{3}{|c|}{ Nhóm tuối nghề (năm) } \\
\hline$<5$ & 111 & 5,6 \\
\hline $5-10$ & 398 & 20,0 \\
\hline $11-15$ & 712 & 35,7 \\
\hline $16-20$ & 233 & 11,7 \\
\hline $21-25$ & 293 & 14,7 \\
\hline $26-30$ & 145 & 7,3 \\
\hline$>30$ & 100 & 5,0 \\
\hline Tuổi nghề & \multirow{2}{*}{\multicolumn{2}{|c|}{$\begin{array}{c}\text { Trung bình } \pm \text { SD } \\
15,6 \pm 7,6\end{array}$}} \\
\hline (năm) & & \\
\hline Tống & 1992 & 100 \\
\hline
\end{tabular}

Trong tổng số 1992 đối tượng nghiên cứu hầu hết là nam giới $(97,4)$. Tuổi trung bình của đối tượng nghiên cứu là $37,3 \pm 6,8$ tuổi với đa số có độ tuổi từ 30-đến 39 , khoảng $1 / 4$ có độ tuổi từ 40 đến 49 tuổi, 11,3\% nhỏ hơn 30 tuổi và chỉ $6,2 \%$ có độ tuổi từ 50 trở lên. Trung bình tuổi nghề của người lao động là 15,6 \pm 7,6 năm, nhóm tuổi nghề từ 11 - 15 năm có tỷ lệ cao nhất $(35,7 \%)$, thấp nhất là nhóm tuổi nghề từ 30 năm trở lên $(5,0 \%)$.

Bảng 2. Tỷ lệ mắc bệnh bụi phổi than theo tuổi và giới

\begin{tabular}{|c|c|c|c|c|c|c|c|}
\hline \multirow{3}{*}{\multicolumn{2}{|c|}{ Đặc điểm }} & \multicolumn{4}{|c|}{ Mắc bệnh bụi phối than } & \multirow{2}{*}{\multicolumn{2}{|c|}{ Tổng }} \\
\hline & & \multicolumn{2}{|c|}{ Có } & \multicolumn{2}{|c|}{ Không } & & \\
\hline & & $\mathbf{n}$ & $\%$ & $\mathbf{n}$ & $\%$ & $\mathbf{n}$ & $\%$ \\
\hline \multirow[t]{4}{*}{ Tuối: } & $<30$ tuối & 3 & 1,3 & 223 & 98,7 & 226 & 11,3 \\
\hline & $30-39$ tuổi & 125 & 11,1 & 1003 & 88,9 & 1128 & 56,6 \\
\hline & $40-49$ tuô̂i & 161 & 31,3 & 353 & 68,7 & 514 & 25,8 \\
\hline & $\geq 50$ tuổi & 26 & 21,0 & 98 & 79,0 & 124 & 6,2 \\
\hline \multirow[t]{3}{*}{ Giời: } & Nam & 315 & 16,2 & 1625 & 83,8 & 1940 & 97,4 \\
\hline & Nũ̃ & 0 & 0,0 & 52 & 100,0 & 52 & 2,6 \\
\hline & Tống & 315 & 15,8 & 1677 & 84,2 & 1992 & 100,0 \\
\hline
\end{tabular}

Tỷ lệ mắc bệnh bụi phổi than ở các đối tượng tham gia nghiên cứu là 15,8\% trong đó tăng dần từ nhóm tuổi dưới 30 đến nhóm tuổi 40 - 49 sau đó tỷ lệ giảm còn $21,0 \%$. Sự khác nhau về tỷ lệ mắc bệnh bụi phổi than theo nhóm tuổi rất có ý nghĩa thống kê (Fisher's Exact test: 153,507, p = 0,0001). Tuổi trung bình mắc bệnh bụi phổi than

là $41,4 \pm 6,1$ tuối, tuối mắc thấp nhất là 24 tuổi, tuổi mắc cao nhất là 58 tuổi. Bảng kết quả cũng cho thấy $16,2 \%$ nam giới mắc bệnh bụi phổi than, nữ không có đối tượng nào bị mắc bệnh bụi phổi than. Sự khác nhau về tỷ lệ mắc bệnh bụi phổi than ở hai nhóm đối tượng có ý nghĩa thống kê (Fisher's Exact test: 18,162, p = 0,0001).

Bảng 3. Tỷ lệ mắc bệnh bưi phổi than theo nhóm tuổi nghề

\begin{tabular}{|c|c|c|c|c|c|c|}
\hline \multirow{2}{*}{ Thâm niên } & \multicolumn{4}{|c|}{ Mắc bệnh bụi phối than } & \multicolumn{2}{c|}{ Tổng } \\
\cline { 2 - 6 } & \multicolumn{3}{|c|}{ Cón } & \multicolumn{2}{c|}{ Không } & \multicolumn{2}{c|}{ \% } \\
\cline { 2 - 6 } & $\mathbf{n}$ & $\mathbf{0}$ & $\mathbf{0}$ & $\mathbf{n}$ & $\mathbf{\%}$ \\
\hline $5-10$ năm & 3 & 2,7 & 108 & 87,3 & 111 & 5,6 \\
$11-15$ năm & 11 & 2,8 & 387 & 87,2 & 398 & 20,0 \\
\hline
\end{tabular}


VIETNAM MEDICAL JOURNAL N01 - SEPTEMBER - 2021

\begin{tabular}{|c|c|c|c|c|c|c|}
\hline $16-20$ năm & 46 & 19,7 & 187 & 80,3 & 233 & 11,7 \\
$21-25$ năm & 94 & 32,1 & 199 & 67,9 & 293 & 14,7 \\
26 - 30 năm & 45 & 31,0 & 100 & 69,0 & 145 & 7,3 \\
$\geq 31$ năm & 21 & 21,0 & 79 & 79,0 & 100 & 5,0 \\
\hline Tống & 315 & 15,8 & 1677 & 84,2 & 1992 & 100,0 \\
\hline
\end{tabular}

Tỷ lệ mắc bệnh bụi phối than tăng dân từ nhóm thâm niên < 5 năm đếm nhóm tuối $21-25$ năm, sau đó giảm ở nhóm tuổi từ 26 đến trên 31 năm. Sự khác nhau về thâm niên mắc bênh bưi than rất có ý nghĩa thống kê (Fisher's Exact test: 165,324, p =0,0001). Thâm niên trung bình mắc bệnh bụi phổi than là 19,9 \pm 6,8 năm.

Bảng 4. Phân bố mắc bệnh bụi phổi than theo kích thước và mật độ đám mờ nhỏ

\begin{tabular}{|c|c|c|}
\hline Đắc điếm & n & $\%$ \\
\hline \multicolumn{3}{|c|}{ Kích thước đám mờ nhỏ } \\
\hline $\mathrm{p} / \mathrm{p}$ & 268 & 85,1 \\
\hline $\mathrm{p} / \mathrm{q}$ & 1 & 0,3 \\
\hline $\mathrm{q} / \mathrm{q}$ & 32 & 10,2 \\
\hline $\mathrm{r} / \mathrm{r}$ & 1 & 0,3 \\
\hline $\mathrm{s} / \mathrm{p}$ & 9 & 2,9 \\
\hline s/s & 1 & 0,3 \\
\hline$t / p$ & 2 & 0,6 \\
\hline$t / t$ & 1 & 0,3 \\
\hline \multicolumn{3}{|c|}{ Mật độ đám mờ nhỏ } \\
\hline Nhóm $1(1 / 0-1 / 2)$ & 191 & 60,6 \\
\hline Nhóm $2(2 / 1-2 / 3)$ & 74 & 23,5 \\
\hline Nhóm $3(3 / 2-3 /+)$ & 50 & 15,9 \\
\hline Cộng & 315 & 100,0 \\
\hline
\end{tabular}

Tỷ lệ đám mờ nhỏ có kích thước $p / p$ chiếm đa số $(85,1 \%)$, tiếp theo là q/q $(10,2 \%)$. Ngoài đám mờ nhỏ tròn đều, trên phim chup phổi của các đối tượng mắc bênh bụi phổi than còn có đám mờ nhỏ không tròn đều nhưng chiếm tỷ lệ thấp. Bảng kết quả cũng chỉ ra rằng tỷ lệ đám mờ nhỏ có mật độ nhóm $1(1 / 0-1 / 2)$ chiếm tới $60,6 \%$, tiếp theo là nhóm $2(2 / 1-2 / 3)$ chiếm $23,5 \%$ và nhóm $3(3 / 2-3 /+)$ chiếm $15,9 \%)$.

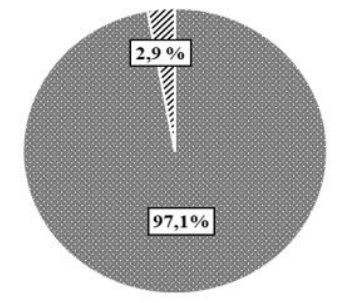

• Thể đơn thuần "Thể biến chứng

\section{Biểu đồ 1. Phân loại bệnh bụi phổi than của} đôi tướng nghiên cứu

Trong tổng số 315 đối tương mắc bênh bui phổi than, tỷ lệ mắc bệnh bụi than thể biến chứng chiếm 2,9\%.

\section{BÀN LUÂN}

Công ty cổ phần than Vàng Danh làm nhiệm vụ khai thác, chế biến, nhập, kinh doanh than và vận tải than... thu hút cả lao động nam và nữ. Ở nhóm người lao động tiếp xúc trực tiếp với bụi than là nam tham gia nghiên cứu ở độ tuổi từ 30 tuổi trở lên chiếm đa số $(88,6 \%)$, ở nhóm lao động nữ giới từ 30 trở lên cũng chiếm phần lớn $(92,3 \%)$ nhưng ở nhóm tuổi từ 50 trở lên tỷ lệ này chỉ chiếm $5,8 \%$. Điều này có thể giải thích sau tuổi 50 , phụ nữ rơi vào thời kỳ mãn kinh, sức khỏe không còn tốt như trước, không còn phù hợp với những công việc nặng nhọc như ngành than, kéo theo tỷ lệ lao động nữ ở độ tuổi này sẽ giảm. Tuổi nghề của người lao động 11 - 15 năm chiếm tỷ lệ cao nhất $(35,7 \%)$ từ 5 năm trở xuống chỉ chiếm tỷ lệ $5,6 \%$ tổng số người lao động tham gia nghiên cứu. Ở cả nhóm nam và nữ tuổi nghề $\geq 31$ năm chiếm tỷ lê thấp nhất $(5,1 \%)$ và cũng tương tự ở nhóm nữ $(3,8 \%)$. Có sự khác nhau về tuối nghề giữa nam và nữ do đặc điểm sinh lý, sức khỏe của nữ giới thường kém dẻo dai, sức bền giảm theo thời gian cùng với giai đoạn mãn kinh nên có tỷ lệ gắn bó với nghề không được lâu dài như nam giới. Khi tuổi càng cao nữ giới có xu hướng chuyển sang những công việc nhẹ nhàng hơn, phù hợp với sức khỏe hơn.

Trên thế giới có nhiều nghiên cứu về tỷ lệ mắc bệnh bụi phổi than, tỷ lệ này khác nhau giữa các vùng, giữa đăc điểm khai thác hầm lò, lộ thiên, khác nhau giữa giới tính, giữa tuổi đời, tuổi nghề, tình trạng hút thuốc hay bệnh nền kèm theo. Kết quả nghiên cứu của chúng tôi cho thây tỷ lệ mắc bênh bụi phổi than là 15,8\%. Kết quả của chúng tồi thấp hơn nhiều so với nghiên cứu của Laney AS và cộng sự (2010) cho thấy nguy cơ mắc bệnh bụi phổi ở công nhân khai thác than hầm lò chiếm tới $48 \%^{3}$. So với các nghiên cứu trong nước, tỷ lệ mắc bệnh bụi phổi than trong nghiên cứu của chúng tổi cũng thấp hơn tại mỏ đá Núi Hồng, Thái Nguyên là $40 \%{ }^{4}$, và Công ty cổ phần than Tây Nam đá mài là $28,5 \%{ }^{5}$. Sự chênh lệch này có thể do địa điểm nghiên cứu khác nhau với các đặc điểm về công việc, bảo hộ lao động, địa hình lao động, điều kiển khí hậu, môi trường khác nhau. Sự khác nhau này cũng do sự khác nhau về mẫu nghiên cứu, và chụp phim Xquang phổi chỉ tập trung vào những đối tượng làm trực tiếp với nơi có 
nguy cơ cao, còn những đối tượng trước đó đã làm việc, tiếp xúc với bụi than, chuyển sang bộ phận khác không được chụp phim phổi.

Về tỷ lệ mắc bệnh bụi phổi than theo giới, trong nghiên cứu của chúng tôi nam bị mắc $16,2 \%$ và nữ không có trường hợp nào mắc và tỷ lệ mắc bệnh bụi phổi than giữa hai nhóm đối tượng này khác nhau có ý nghĩa thống kê (Fisher's Exact test $=18,162 ; \mathrm{p}=0,0001$ ). Trong khi nghiên cứu của Shen và cộng sự lại chưa tìm thấy sự khác nhau về tỷ lệ mắc bệnh bụi phổi than giữa giới nam và nữ. Về tuổi đời: kết quả nghiên cứu của chúng tôi cho thấy nhóm tuổi có tỳ lệ người lao động mắc bệnh bụi phổi than nhiều nhất là các nhóm tuổi 30 - 39 và từ 40 - 49 tuổi). Kết quả nghiên cứu của Shen và cộng sự cho thấy tuổi bị mắc bệnh bụi phổi than có thể gặp ở mọi lứa tuổi và việc phát bệnh phụ thuộc vào thâm niên và nồng độ bui than đã tiếp xúc, phụ thuộc thời gian bắt đâu làm việc tại các mỏ than. Tỷ lệ mắc bệnh tăng lên khi tiếp xúc với bụi than hổ hấp nồng độ lớn. Điều này có thể lý giải do đây là công việc nặng nhọc những người lao động có tuổi đời càng cao, tiếp xúc với bụi than càng nhiều có tỷ lệ mắc bệnh bụi phổi than càng cao và cao hơn so với những người lao động ở nhóm tuổi trẻ hơn. Về tuổi nghề kết quả nghiên cứu của chúng tôi cho thấy tỷ lệ hiện mắc bệnh bụi than ở Công ty cổ phần than Vàng Danh tăng dần theo nhóm tuổi nghề, nhóm tuổi nghề có tỷ lệ mắc bệnh nhiều nhất là nhóm 21 25 và 26-30. Tuổi nghề trung bình mắc bệnh bụi phổi là $19,9 \pm 6,8$ năm. Kết quả này thẩp hợn nghiên cứu của Lei Han và cộng sự về trung bình tuổi đời mắc bệnh bụi phổi than. Sự khác nhau này có lẽ do cỡ mẫu nghiên cứu cũng như tình trạng khai thác than, kỹ thuật khai thác và công nghệ khai thác than khác nhau tùy từng nước.

Nghiên cứu của chúng tôi cho thây đa số là tổn thương đám mờ nhỏ kích thước $\mathrm{p} / \mathrm{p}$ $(85,1 \%)$, còn đám mờ nhỏ kích thước $q / q$ chiếm $10,2 \%$, kết quả này có sự khác biệt với nghiên cứu của Carlos Humberto Torres Rey và cộng sự8 tỷ lệ đối tượng mắc bệnh bụi phổi với kích thước đám mờ nhỏ $\mathrm{p} / \mathrm{p}$ chung cho cả hai vùng chỉ chiếm $10,0 \%$, trong khi đó đám mờ có kích thước q/q chiếm 39,4\%. Về mật độ đám mờ, trong nghiên cứu của chúng tôi ghi nhận tất cả mật độ đám mờ từ trong đó mật độ đám mờ nhóm 1 chiếm đa số, mật độ đám mờ nhóm 2 chiếm khoảng $1 / 4$ và nhóm 3 chiếm tỷ lệ $15,9 \%$. Kết quả nghiên cứu của chúng tôi tươning đồng với kết quả của Lei Han và cộng sự . Hầu hết đối tượng mắc bệnh bui phổi than trong nghiên cứu của chúng tôi là thể đơn thuần, chỉ có 2,9\% là thể biến chứng, tỷ lệ này cao hơn nghiên cứu của Laney AS và cộng sự 9 Sự khác biệt này có thể do môi trường làm việc khác nhau, tuổi nghề của đối tượng nghiên cứu khác nhau nên có thể tiếp xúc với nồng độ bụi than khác nhau.

\section{KẾT LUÂN}

Tỷ lệ hiện mắc bệnh bụi phổi than chiếm $15,8 \%$, trong đó tỷ lệ mắc bệnh bụi phổi than thể biến chứng là $2,9 \%$. Đa số đám mờ nhỏ có kích thước $\mathrm{p} / \mathrm{p}(85,1 \%)$ và mật độ tổn thương ở nhóm $1(60,6 \%)$. Để giảm tỷ lệ mắc bệnh bụi phổi than, cần phải có những biện pháp cụ thể, chủ động bao gồm các biện pháp phòng hộ cá nhân, các biện pháp kỹ thuật sản xuất để cái thiện điều kiện lao động và giảm thiểu phơi nhiê̂m với bụi than cho người lao động. Đặc biệt cần kết hợp khám phát hiện bệnh nghề nghiệp cùng với khám sức khỏe định kì cho người lao động ngành than.

\section{TÀI LIỆU THAM KHẢO}

1. Bộ $Y$ tế. Bệnh bụi phổi than nghề nghiệp. Accessed Trúy cập ngày 5 tháng 3 năm 2021, https://moh.gov.vn/web/phong-chong-benh-nghenghiep/thong-tin-hoat-dong/-

/asset_publisher/xjpQsFUZRw4q/content/benh-buiphoi-than-nghe-nghi-1?

2. Shen Fuhai, Yuan Juxiang, Sun Zhiqian, et al. Risk identification and prediction of coal workers' pneumoconiosis in Kailuan Colliery Group in China: a historical cohort study. PLoS One. 2013;8(12):e82181.

3. Laney A Scott, Attfield Michael D. Coal workers' pneumoconiosis and progressive massive fibrosis are increasingly more prevalent among workers in small underground coal mines in the United States. Occupational and environmental medicine. 2010;67(6):428-431.

4. Khương Văn Duy, Nguyễn Ngọc Hông, Lê Quang Chung. Thực trang mắc bệnh bụi phổi than tại mỏ than núi Hồng, Thái Ṅguyên, năm 2018. Y học dự phòng. 2018;29(15):102-105.

5. Khương Văn Duy, Phan Mai Hương, Lê Quang Chung. Mô tả một số đặc điểm lâm sàng về bệnh đường hô hấp ở người lao động tại cổng ty cổ phần than Tay nam đá mài, Vinacomin, 2019. Y hoc dự phòng. 2019;30(4):227-230.

6. Shen $\mathbf{H N}$, Jerng JS, Yu CJ. Outcome of coal worker's pneumoconiosis with acute respiratory failure. Chest. Mar 2004;125(3):1052-8. doi:10.1378/chest.125.3.1052

7. Lei Han, Ruhui Han, Xiaoming Ji, et al. Prevalence characteristics of coal workers' pneumoconiosis (CWP) in a state-owned mine in Eastern China. International journal of environmental research and public health. 2015; 12(7):7856-7867.

8. Carlos Humberto Torres Rey, Ibañez Pinilla M, Leonardo Briceño Ayala, et al. Underground coal mining: relationship between coal dust levels and pneumoconiosis, in two regions of Colombia, 2014. BioMed research international. 2015;2015. 


\section{GIÁ TRİ CỦA CHỈ SỐ BÃO HÒA OXY TĨNH MACH TRUNG TÂM TRONG DỰ ĐOÁN KHẢ NĂNG THÔI THỞ MÁY Ở BẾNH NHÂN NHỒI MÁU CƠ TIM CẤP PHẢI THÔNG KHÍ NHÂN TẠO XÂM NHẬP}

\section{TÓM TẮT}

Mục tiêu: Đánh giá khả năngdự đoán thất bại thôi thở máy (TTM) của chỉ số bão hòa oxy tĩnh mạch trung tâm (ScvO2) ở bệnh nhân nhồi máu cơ tim cấp (NMCT) nặng phải thổng khí nhân tạo xâm nhập (TKNTXN) >72 giờ. Phương pháp nghiên cứu: Nghiên cứu mô tá tiến cứu tiển hành tại khoa hồi sức tim mạch $\mathrm{C} 1$ bệnh viện Bach Mai trển nhóm bệnh nhân NMCT phải thiết lập TKNTXN có thời gian thở máy $>72$ giờ, đã đủ tiêu chuẩn TTM và được bác sĩ điều trị quyết định thực hiện thử nghiệm thở tự nhiên (TNTTN). Bệnh nhân sẽ được thu thập các thông tin về lâm sàng, cận lâm sàng đồng thời thực hiện lấy 2 mẫu khí máu tînh mach trung tâm vào 2 thời điểm ngay trước (T1) và phút thứ 30 (T2) của TNTTN. Kết quả: Có 25 bệnh nhân được đưa vào nghiên cứu, trong đó có 14 bệnh nhân TTM thành công và 11 bệnh nhân TTM thất bai. ScvO2 và tần số tim ở thời điểm T2 khác biệt có ý nghĩa thống kê giữa 2 nhóm $(69.87 \pm 3.9 \%$ và $63.84 \pm 6.54 \% ; \quad p=0.009 ; 103.5$ (99.5-107) và $111.0(106-113) ; p=0.008)$. Nghiên cứu của chúng tôi cho thây mức giảm ScvO2 lớn hơn $4.5 \%$ có khả năng dự đoánthất bai của quá trình TTM với độ nhạy là $72.7 \%$, độ đặc hiệu là $85.7 \%$. Kết luận: Sự sut giảm của chỉ số ScvO2(\%) giữa 2 thời điểm ngay trước và phút thứ 30 trong quá trình thực hiện TNTTN có thể dư đoán khả năng thất bại TTM ở bệnh nhân NMCT năng phải thở máy.

Tư khóa: ScvO2; Nhồi máu cơ tim cấp; Thông khí nhân tạo xâm nhập

\section{SUMMARY}

\section{VALUE OF CENTRAL VENOUS OXYGEN SATURATION TO DETECT WEANING FAILUREIN SEVERE ACUTE MYOCARDIAL INFRACTIONWHO MUST INVASIVE MECHANICAL VENTILATION}

Objectives: To evaluate the ability of central venous oxygen saturation (ScvO2) to detect weaningfailure(WF) in severe acute myocardial infraction(MI) who must invasive mechanical ventilation (MV) $>72$ hours. Methods: prospective observational study was conducted at cardiac intensive care unit C1 Bach Mai Hospital in severe MI needed mechanical ventilation $>72$ hours, fulfilling of the

\footnotetext{
${ }^{1}$ Bệnh viện Đa khoa 115 Nghệ An

${ }^{2}$ Trường Đại học Y Hà Nội

Chịu trách nhiệm chính: Hồ Đức Manh

Email: xpart201vn@gmail.com

Ngày nhận bài: 25.6.2021

Ngày phản biện khoa học: 19.8.2021

Ngày duyệt bài: 15.8.2021
}

\author{
Hồ Đức Mạnh', Phạm Minh Tuấn ${ }^{2}$
}

weaning criteria and have the clinical decision for spontaneous breathing trial (SBT). We collected the clinical, subclinical information and 2 samples of central venous blood gas before the SBT (T1) and $30^{\text {th }}$ min of SBT(T2). Result: Twenty five patients were enrolled in the study, there were fourteensuccessful weaning patients and eleven failed weaning patients. At the T2, ScvO2 decreased significantly while the heart increased significantly between two group $(69.87 \pm 3.9 \%$ vs $63.84 \pm 6.54 \% ; p=0.009 ; 103.5(99.5-$ 107) vs $111.0(106-113) ; p=0.008)$. In our study, a reduction of ScvO2 by $>4.5 \%$ between before and the $30^{\text {th }}$ min of SBT can predict weaning failure with sensivity $72.7 \%$, Specificity $85.7 \%$ and odds ratio 16 (confidence interval $=2.165-118.27, \mathrm{p}=0.005$ ). Conclusion: reduction of $\mathrm{ScvO} 2$ between before and the $30^{\text {th }} \mathrm{min}$ of SBT can predictability in weaning failure detection in severe myocardial infraction who needs invasive mechanical ventilation.

Keywwords: ScvO2; Myocardial infraction; Mechanical ventilation

\section{I. ĐẶT VẤN ĐỀ}

Thôi thở máy (TTM) là một khâu quan trọng trong chăm sóc bệnh nhân nặng, thành công của TTM là yếu tố quyết định thành công của thông khí nhân tạo xâm nhập. Do thở máy kéo dài gây nên nhiều nguy về viêm phổi, chấn thương phổi... nênvấn đề cố gắng ngừng thông khí nhân tạo xâm nhập sớm nhất khi tình trạng bệnh nhân cho phép luôn được các nhà lầm sàng đồng thuận từ lâu. Mặc dù vậy, một quyết định quá sớm hay cố gắng TTM kéo dài không hiệu quả dẫn đến thất bại của quá trình này kéo theo việc đặt lại nội khí quản, thiết lập lại thông khí nhẩn tạo cũng làm tăng thời gian thở máy, tăng thời gian nằm viện và tỉ lệ tử vong ${ }^{1}$.

TTM là một quá trình thay đổi về huyết động và thông khí, gây nên sự ảnh hưởng không nhỏ lên bệnh nhân và tác dụng này được khuyếch đại trên nhóm bệnh nhân nặng với chức năng tim - phổi không ổn định. Tác động về mặt huyết động của TTM bao gồm 3 xu hướng chính²: (1)Giảm áp suất lồng ngực gây tăng hồi lưu tĩnh mạch làm tăng tiên gánh thất trái. (2)Giảm áp lực mạch máu phổi, gây giảm hậu gánh thất phải và tăng đổ đầy thất trái.(3)Tăng áp lực xuyên thành gây tăng hậu gánh thất trái. Tác động về mặt hô hấp của TTMM lên bênh nhân bao gồm²: (1)Tăng công hô hấp. (2)Giảmthông khí, giảm oxy hóa máu, xẹp phế nanggóp phần 
gây tăng kháng trở mạch máu phổi.(3)Mất đi tác động của PEEP lên phế nang, có thể làm mất cân bằng thủy tĩnh trong phế nang, ứ dịch khoảng kẽ, gây giảm compliance phổi và tăng resistance phổi. Ngoài những yếu tố trên, hoạt hóa hệ giao cảm trong quá trình TTM cũng gây nên ảnh hưởng không nhỏ trên quá trình cung - cầu oxy của bệnh nhân.Việc gia tăng hoạt động của các cơ hô hấp nhằm bù trừ cho các biển đổi trong quá trình TTM kéo theo sự tăng mạnh nhu cầu oxy, qua đó đòi hỏi cung lượng tim tăng tương ứng, song song với đó là việc tăng lên của tiền gánh và hậu gánh dẫn đến gánh nặng phải nhận của tim là rất lớn.

Nhồi máu cơ tim cấp (NMCT) là bệnh lý thường gặp tại các khoa hồi sức tim mạch và là nguyên nhân hàng đầu của bệnh nhân suy tim cấp, thông khí nhân tạo xâm nhập hay thở máy là một biện pháp cứu cánh cho tình trạng suy hô hấp của NMCT cấp nặng. Rõ ràng trền một trái tim với một hệ mạch vành đã tổn thương, một chức năng tim đã suy giảm nặng thì mối cần bằng cung - cầu oxy của cơ thể đó là vô cùng mong manh. Chính vì lẽ đó, khi các yếu tố cơ bản của cơ thể như khả năng oxy hóa máu của phổi, thăng bằng nội môi, ý thức, tình trạng nhiếm trùng, ... của cơ thể đã tương đối ổn định thì khả năng đảm bảo được cân bằng cung - cầu oxy khi TTM của tim quyết định rất lớn vào việc thành công hay thất bại của quá trình TTM ở bệnh nhân NMCT ${ }^{3}$.

Chưa có một thang điểm hay biện pháp nào có thể tiên đoán hoàn toàn kết cục quá trình TTM bởi có rất nhiều yếu tỗ ảnh hưởng tới kết quả này. Xét riêng trên phương diện thất bại TTM do nguyên nhân tim mạch, hiện nay, đang được các tác giả đang tập trung nghiên cứu. Các phương pháp này đều có nguyên lý chung là khảo sát sự thay đổi của cơ thể trong thời gian thực hiện TNTTN bằng thăm dò huyết động (Picco, siêu âm tim qua thành ngực...), xét nghiệm máu (pro BNP, ScvO2) hay siêu âm phổi ${ }^{4}, 5$. Mặc dù vậy, trong điều kiện nước ta hiện nay, các kĩ thuật thăm dò huyết động hay siểu âm vẫn chưa trở thành một thăm dò̀ thường quy vì đòi hỏi nhiêu về con người và máy móc.

ScvO2 với mối tương quan chặt chẽ với SvO2, được coi là một sự thay thế cho SvO2 trong lâm sàng, có khả năng đánh giá cân bằng cung - cầu oxy trong cơ thể ${ }^{6}$. Nghiên cứu của Jubrand và Tobin cho thây ở các bệnh nhân thành công TTM, nhu cầu oxy tăng lên không quá nhiêu, trong khi đó quá trình vận chuyển cung cấp oxy tăng lên rất nhiều qua đó kéo theo mức chiết oxy cần thiết không tăng, vì vậy $\mathrm{SvO2} \mathrm{ở} \mathrm{nhóm}$ bệnh nhân này là không đổi. Ngược lại, trong nhóm TTM thất bại, mặc dù tiêu thụ oxy tăng vọt nhưng cung cấp oxy không tăng mà ngược lại có xu hướng giảm đi và kéo theo mức chiết oxy tăng lên, qua đó kéo theo sự giảm xuống của chỉ số SvO2 (61.3 $55.8 \%$ xuống $51.5 \pm 7.9 \%)^{7}$. Tương tự,nghiên cứu của Teixeira, nhận thấy mức giảm của ScvO2 lần lượt là $4.5 \%$ có khả năng dự đoán thất bại TTM với độ nhạy và độ đặc hiệu $\mathrm{caO}^{5}$.

Chính vì vậy chúng tôi tiến hành nghiên cứu này nhằm đánh giá giá trị của $\mathrm{ScvO2}$ trong dự đoán khả năng TTM ở nhóm bệnh nhân NMCT nặng (thở máy > 72giờ).

\section{II. ĐỐI TƯỢNG VÀ PHƯƠNG PHÁP NGHIÊN CỨU}

Đối tượng nghiên cứu: Thời gian từ tháng 6/2020 tới tháng 8/2021 tại khoa C1 tim mạch bệnh viện Bạch Mai. Chúng tôi tiến hành thu thập thổng tin lâm sàng, cận lâm sàng, xét nghiệm khí máu tĩnh mach trung tâm trên nhóm bệnh nhân đã được chẩn đoán nhồi máu cơ tim cấp, thở máy $>72$ giờ vì suy hô hấp, sau khi tình trạng đã ổn định, được xét tiến hành thôi thở máy khi đủ các tiêu chuẩn thực hiện thử nghiệm thở tự nhiên ${ }^{8}$. Bao gồm: a, Không rối loạn tri giác, không còn tác dụng của an thần giãn cơ; $b$, Nhiểm trùng hô hấp được bác sĩ lâm sàngđánh giá ổn định (lượng đàm giảm, không sốt, các chỉ số viêm giảm, oxy hóa máu cải thiện...); c,Khả năng oxy hóa máu phù hợp ( $\mathrm{PaO} 2 / \mathrm{FiO}^{2}$ $>150 \mathrm{mmHg}$ ); d, Huyết động ổn định (nhịp tim $<140 \mathrm{l} / \mathrm{p}$, không dùng vận mạch hoặc dùng ở mức rất thấp); e,Hemoglobin $>7 \mathrm{~g} / \mathrm{dL}$; $\mathrm{f}$, Không rối loạn thân nhiệt; $g$, Ho khạc tốt; $h$, Cân bằng điện giải. Tiêu chuẩn loại trừ: loạn nhịp hoặc tử vong trong quá trình TTM, dị dạng lî̀ng ngực hoặc bất thường đường thở, bệnh nhân mở khí quản, rối loạn ý thức, có bệnh lý thần kinh - cơ, mất máu cấp tính, tiền sử COPD, bất thường hồi lưu tĩnh mạch hay shunt tuần hoàn, bệnh nhân hoặc người nhà không đồng ý tham gia nghiên cứu.

Quy trình thôi thở máy: Sau khi được bác sĩ lâm sàng xác định đủ điều kiện tiến hành thử nghiệm thở tự nhiên (TNTTN) đã nói ở trên, tiến hành TTM bằng phương pháp hỗ trợ áp lực tối thiểu $(\leq 7 \mathrm{cmH} 2 \mathrm{O}, \leq$ PEEP $5 \mathrm{cmH} 2 \mathrm{O})$.

Tiến hành TNTTN trong vòng 2 tiếng, đánh giá thành công TNTTN và ra quyết định rút NKQ.Thất bại TTN được định nghĩa là thất bại TNTTN hoặc phải đặt lại NKQ trong vòng 48giờ sau rút nội khí quản 3,5 .

Phương pháp thống kê: Thống kê mô tả 
bằng trung bình và độ lệch chuẩn với số liệu phân bố chuẩn, trung vị và khoảng tứ phân vị với phân bố không chuẩn. Kiểm định sự khác biêt bằng $\mathrm{t}$ test độc lập và mann whitney $\mathrm{u}$ test. Kiểm đinh mối liên quan giữa các biến đinh tính bằng test $\chi 2$ hoặc Fisher với $\mathrm{p}<0.05$. Sử dụng đường cong ROC để tìm điểm cut - off tối ưu với test dự đoán. Sử dụng hồi quy logistic đa biến tìm ra yếu tố dự đoán kết quả độc lập.

\section{KẾT QUẢ NGHIÊN CỨU}

Từ tháng 6/2020 tới tháng 8/2021 tại khoa C1 tim mạch bệnh viện Bạch Mai, chúng tôi ghi nhận 25 bệnh nhân đã được chẩn đoán nhồi máu cơ tim cấp, suy hô hấp, thở máy>72 giờ,đủ các tiêu chuẩn thực hiên TNTTN.Trong số các bênh nhân này, thất bại thôi thở máy có $11 / 25$ bệnh nhân chiếm 44\%.

Bảng 1: Đăc điểm bênh nhân nghiên cứu:

\begin{tabular}{|c|c|c|c|}
\hline Đă̆c điếm & TTM thành công (n=14) & TTM thất bại (n=11) & P value \\
\hline Giới nam/nữ & $11 / 3(78.6 \% / 21.4 \%)$ & $3 / 1(75 \% / 25 \%)$ & 0.604 \\
\hline Tuối & $72.29 \pm 9.343$ & $72.91 \pm 10.144$ & 0.875 \\
\hline BMI & $20.8 \pm 2.5$ & $21.7 \pm 1.9$ & 0.326 \\
\hline Sốc tim* & $2 / 12(14.3 \% / 85.7 \%)$ & $7 / 4(63.6 \% / 36.4)$ & $\mathbf{0 . 0 1 7}$ \\
\hline Stemi/Nstemi & $7 / 7(50 \% / 50 \%)$ & $7 / 4(63.6 \% / 36.4)$ & 0.689 \\
\hline Tái tưới máu (có/không) & $9 / 5(64.3 \% / 35.7 \%)$ & $5 / 6(45.5 \% / 54.5 \%)$ & 0.346 \\
\hline Viêm phốí (có/không) & $7 / 7(50 \% / 50 \%)$ & $9 / 2(81.8 \% / 18.2 \%)$ & 0.208 \\
\hline Suy thận cấp (có/không) & $3 / 11(21.4 \% / 78.6 \%)$ & $5 / 6(45.5 \% / 54.5 \%)$ & 0.187 \\
\hline Thời gian thơ máy & $5.0(4.0-6.0)$ & $7.0(5.0-7.0)$ & 0.082 \\
\hline
\end{tabular}

*Lúc nhâp khoa C1.

Tình trạng sốc tim ở bệnh nhân thời điểm nhập khoa C1 có liên quan tới kết cục của quá trình TTM với $\mathrm{p}<0.05$

Bảng 2: Cận lâm sàng trước thử nghiệm thở tự nhiên:

\begin{tabular}{|c|c|c|c|}
\hline Thông số & TTMthành công & TTMthất bại & P value \\
\hline CRPhs(mg/dL) & $4.5(3-10.75)$ & $9.0(7-17)$ & $\mathbf{0 . 0 1 1}$ \\
\hline Creatinin(mmol//L) & $113(88.75-147.5)$ & $143(123-223)$ & 0.071 \\
\hline GFR(ml/p/1.73 & $50(34-68.75)$ & $45(24-50)$ & 0.162 \\
\hline ProBNP(pg/mL) & $1573.5(776.53-2830.25)$ & $2977(1186-4139)$ & 0.198 \\
\hline TroponinT(ng/L)* & $822(382.4-1276.5)$ & $2558(527-5047)$ & 0.071 \\
\hline Lactate $(\mathrm{mmol} / \mathrm{L})$ & $2.53 \pm 1.09$ & $2.57 \pm 0.97$ & 0.923 \\
\hline
\end{tabular}

*Lấy giá trị lúc nhập C1 trong vòng 48h (lấy giá trị cao nhất)

Có sự khác biệt giữa chỉ số CRPhs ở nhóm TTM thất bại với nhóm TTM thành công với $p=0.011$.

Bảng 3: Khí máu động mach, huyết hoc và thông số cơ học phổi:

\begin{tabular}{|c|c|c|c|}
\hline Thông số & TTM thành công & TTM thất bại & P value \\
\hline $\mathrm{pH}(\mathrm{a})$ & $7.429 \pm 0.042$ & $7.436 \pm 0.046$ & 0.747 \\
\hline $\mathrm{PaO} 2$ & $121.543 \pm 28.00$ & $123.455 \pm 34.869$ & 0.884 \\
\hline $\mathrm{PaO} 2 / \mathrm{fiO} 2$ & $283.375 \pm 51.319$ & $256.136 \pm 44.725$ & 0.177 \\
\hline $\mathrm{SaO} 2$ & $98.571 \pm 0.9442$ & $98.564 \pm 1.0893$ & 0.985 \\
\hline HCO3-(a) & $24.25(23.58-25.95)$ & $24.2(22.4-31.2)$ & 1.00 \\
\hline $\mathrm{PaCO} 2$ & $38.079 \pm 3.751$ & $39.3 \pm 4.669$ & 0.475 \\
\hline Hemoglobin $(\mathrm{g} / \mathrm{l})$ & $108.14 \pm 17.514$ & $99.45 \pm 20.878$ & 0.269 \\
\hline Hemantocit (\%) & $32.81 \pm 4.66$ & $31.46 \pm 5.81$ & 0.525 \\
\hline WBC (G/L) & $13.08 \pm 3.15$ & $14.11 \pm 3.6$ & 0.459 \\
\hline Cstat* $(\mathrm{ml} / \mathrm{cmH} 2 \mathrm{O})$ & $55.3(47.9-57.7)$ & $48.2(47.3-54.7)$ & 0.118 \\
\hline Resistance*(cmH2O/L.s) & $6.4 \pm 1.66$ & $7.64 \pm 2.63$ & 0.165 \\
\hline $\mathrm{MIP}(\mathrm{cmH} 2 \mathrm{O})^{* *}$ & $36.5(35.75-38)$ & $34(32-38)$ & 0.104 \\
\hline Tidal volume $(\mathrm{ml})^{* *}$ & $439(385.75-472.5)$ & $410(342-454)$ & 0.381 \\
\hline $\mathrm{TV} / \mathrm{kg}(\mathrm{ml} / \mathrm{kg})^{* *}$ & $7.35(6.975-7.65)$ & $6.5(6.3-7.5)$ & 0.075 \\
\hline Srbi** & $53.5(47.425-67.85)$ & $58.8(44-74.1)$ & 0.477 \\
\hline
\end{tabular}

*Thực hiện trước khi dừng an thần, trước TNTTN trong vòng 24h.

**Phút thứ 5 TNTTN.

Bảng 4: Thông số lâm sàng và khí máu tĩnh mạch trung tâm ngay trước khi tiến hành TNTTN và thời điểm 30 phút của TNTTN: 


\begin{tabular}{|c|c|c|c|c|c|c|}
\hline \multirow{2}{*}{ Thông số } & \multicolumn{3}{|c|}{ Ngay trước TNTTN } & \multicolumn{3}{c|}{ Phút thứ 30 TNTTN } \\
\cline { 2 - 7 } & $\begin{array}{c}\text { TTM } \\
\text { thành công }\end{array}$ & $\begin{array}{c}\text { TTM } \\
\text { thất bại }\end{array}$ & $\mathbf{P}$ & $\begin{array}{c}\text { TTM } \\
\text { thành công }\end{array}$ & $\begin{array}{c}\text { TTM } \\
\text { thất bại }\end{array}$ & $\mathbf{p}$ \\
\hline $\mathrm{pH}(\mathrm{v})$ & $7.39 \pm 0.028$ & $7.39 \pm 0.065$ & 0.623 & $7.39 \pm 0.035$ & $7.38 \pm 0.048$ & 0.721 \\
\hline $\mathrm{PcVO} 2$ & $44.12 \pm 4.14$ & $42.55 \pm 5.34$ & 0.414 & $43.33 \pm 5.67$ & $40.04 \pm 5.32$ & 0.152 \\
\hline ScvO2 & $69.79 \pm 2.56$ & $70.6 \pm 4.6$ & 0.606 & $69.87 \pm 3.9$ & $63.84 \pm 6.54$ & $\mathbf{0 . 0 0 9}$ \\
\hline HCO3- & 25.2 & 25.5 & 0.848 & 25.5 & 24.6 & 1.00 \\
\hline PcvCO2 & $(24.33-25.8)$ & $(23.1-31.5)$ & & $(24.2-26.13)$ & $(23.2-32.8)$ & \\
\hline MAP & $83.11 \pm 2.139$ & $43.84 \pm 4.57$ & 0.604 & $43.51 \pm 3.199$ & $46.32 \pm 4.20$ & 0.071 \\
\hline Nhịp thở & $20.54 \pm 10.97$ & $77.73 \pm 6.82$ & 0.067 & $85.07 \pm 10.98$ & $79 \pm 7.7$ & 0.134 \\
\hline Tần số tim & $97.36 \pm 8.68$ & $21(18-27)$ & 0.44 & $25.43 \pm 2.85$ & $27.45 \pm 3.27$ & 0.111 \\
\hline CVP & $11.36 \pm 3.46$ & $97.45 \pm 9.97$ & 0.979 & $103.5(99.5-107)$ & $111.0(106-113)$ & $\mathbf{0 . 0 0 8}$ \\
\hline SpO2 & $96.57 \pm 1.65$ & $95.27 \pm 4.31$ & 0.082 & $13.5 \pm 3.23$ & $16.64 \pm 4.48$ & 0.053 \\
\hline Bang & & 0.069 & $93(92-93.25)$ & $92(91-93)$ & 0.09 \\
\hline
\end{tabular}

Bảng 5: Hồi quy logistic đa biến các yêu tố liên quan tới thất bại TTM:

\begin{tabular}{|c|c|c|}
\hline Thông số & $\begin{array}{c}\text { Hồi quy đơn } \\
\text { biên }(\mathrm{p})\end{array}$ & $\begin{array}{c}\text { Hồi quy đa } \\
\text { biến }(\mathrm{p})\end{array}$ \\
\hline$\Delta \mathrm{ScvO2}(\%)^{*}$ & 0.015 & $\mathbf{0 . 0 4 6}$ \\
\hline$\Delta \mathrm{HR}(\%)^{* *}$ & 0.035 & 0.117 \\
\hline $\mathrm{CRP}$ & 0.129 & 0.153 \\
\hline
\end{tabular}

${ }^{*} \Delta \mathrm{ScvO} 2(\%)=\mathrm{ScvO2}(\mathrm{T} 1)-\mathrm{ScvO} 2(\mathrm{~T} 2)$

$* * \Delta \mathrm{HR}(\%)=(\mathrm{HR} 1-\mathrm{HR} 2) / \mathrm{HR} 1.100(\%)$

Hồi quy logistic cho thây chỉ có $\Delta \mathrm{ScvO2}(\%)$ là biến độc lập duy nhất có khả năng dự đoán thất bại TTM.

Điểm cắt mức độ giảm ScvO2 4.5\% giữa thời điểm ngay trước TNTTN và phút thứ 30 của TNTTN có giá trị tiên lượng tốt, với độ nhạy là $72.7 \%$, độ đặc hiệu là $85.7 \%$, PPV $80 \%$, NPV $80 \%$ và diện tích dưới đường cong ROC: $A U C=$ $0.854(p=0.007)$

Đồ thị 1: Đường cong ROC cho khả năng dự đoán thất bại TTM:

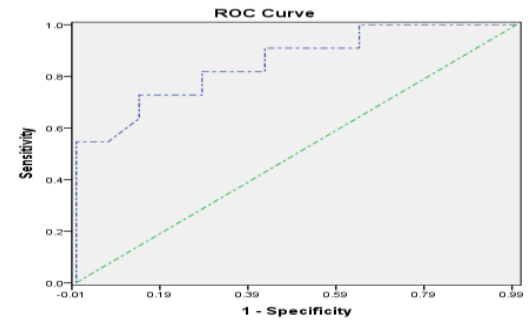

\section{BÀN LUẬN}

Kết quả nghiên cứu của chúng tôi cho thấy mức giảm của ScvO2(\%) 4.5\% giữa thời điểm ngay trước TNTTN và phút thứ 30 của TNTTN có thể dự đoán thất bại của quá trình TTM.

Lý giải cho kết quả nghiên cứu này, theo Boles, trên nhóm bệnh nhân NMCT nặng đã đủ điều kiện xét thôi thở máy, với tình trạng viêm phổi điều trị tương đối ổn định (không sốt, chỉ số bạch cầu giảm, oxy hóa máu tốt, lượng đàm và màu sắc đàm cải thiện), điện giải và toan kiềm không rối loạn, bệnh nhân ý thức tốt và không có bênh lý thần kinh - cơ, không có mất máu cấp tính, nguyên nhân gây nên khó TTM ở nhóm bệnh nhân này đó chính là do tăng tải của tuần hoàn và hô hấp ${ }^{3}$. Chúng tôi cho rằng việc mất cân bằng cung - cầu oxy trong quá trình cai thở máy do tăng nhu cầu oxy để thực hiện công hô hấp, đòi hỏi việc tăng hoạt động của tim nhằm cung cấp đủ oxy, trong khi đó chức năng của tim ở nhóm TTM thất bại có lẽ không còn "dự trữ" đủ để đáp ứng sự thay đổi này. Trong một nghiên cứu của Teboul và Liu, các tác giả này nhânn thây rằngmột trạng thái preload independence (độc lập tiền gánh) được đánh giá bằng test nâng chân thụ động có kết quả âm tính (CO tăng bé hơn $10 \%$ ) có khả năng dự báo một thất bại TTM do tim $\mathrm{cao}^{9}$. Điều đó gợi ý một điểu rằng thất bai TTM do tim sẽ tránh được khi mà bệnh nhân đạt được một trạng thái mà khi đó tim vẫn còn dự trữ khi tiền gánh đột ngột tăng lên, điều đó đặt ra việc quản lý tốt hợn cân bằng dịch trong cơ thể cũng như đánh giá khả năng làm việc của tim trong việc sẵn sàng TTM. Song song với đó nên là quá trình tối ưu hóa các tải của hồ hấp như: Điều trị viêm phổi tích cực; Bổ sung oxy đầy đủ hoặc thở máy không xẩm lấn sau rút nội khí quản; Giảm khoảng chết hô hấp(mơ khí quản); Điều trị phù nề thanh quản; Giảm tối đa các tác động áp lực lên hô hấp như chọc hút dịch màng phổi, đặt lại tư thế bệnh nhân, điều trị tăng áp lực ổ bụng; Giảm tiêu thụ oxy và kích thích giao cảm (giảm đau, dùng thuốc chống lo âu hợp lý).

\section{KẾT LUÂ̂N}

Sự sụt giảm của chỉ số ScvO2(\%) giữa 2 thời điểm ngay trước và phút thứ 30 trong quá trình thực hiện TNTTN có thể dự đoán khả năng thất bại TTM ở bệnh nhân NMCT nặng phải thở máy. 
TÀI LIÊU THAM KHẢO

1. Epstein, S. K.; Ciubotaru, R. L. Independent Effects of Etiology of Failure and Time to Reintubation on Outcome for Patients Failing Extubation. Am. J. Respir. Crit. Care Med.1998, 158 (2), 489-493.

2. Alviar, C. L.; Miller, P. E.; McAreavey, D.; Katz, J. N.; Lee, B.; Moriyama, B.; Soble, J.; van Diepen, S.; Solomon, M. A.; Morrow, D. A. Positive Pressure Ventilation in the Cardiac Intensive Care Unit. J. Am. Coll. Cardiol.2018, 72 (13), 1532-1553.

3. Boles, J.-M.; Bion, J.; Connors, A.; Herridge, M.; Marsh, B.; Melot, C.; Pearl, R.; Silverman, H.; Stanchina, M.; Vieillard-Baron, A.; Welte, $\mathrm{T}$. Weaning from Mechanical Ventilation. Eur. Respir. J.2007, 29 (5), 1033-1056.

4. Vignon, P. Cardiovascular Failure and Weaning. Ann. Transl. Med.2018, 6 (18), 354-354.

5. Teixeira, C.; da Silva, N. B.; Savi, A.; Vieira, S. R. R.; Nasi, L. A.; Friedman, G.; Óliveira, R. P.; Cremonese, R. V.; Tonietto, T. F.; Bressel, M. A. B.; Maccari, J. G.; Wickert, R.; Borges, L. G. Central Venous Saturation Is a Predictor of Reintubation in Difficult-to-Wean Patients. Crit. Care Med.2010, 38 (2), 491-496.
6. Walley, K. R. Use of Central Venous Oxygen Saturation to Guide Therapy. Am. J. Respir. Crit. Care Med.2011, 184 (5), 514-520.

7. Jubran, A.; Mathru, M.; Dries, D.; Tobin, M. J. Continuous Recordings of Mixed Venous Oxygen Saturation during Weaning from Mechanical Ventilation and the Ramifications Thereof. Am. J. Respir. Crit. Care Med.1998, 158 (6), 1763-1769.

8. MacIntyre, N. R.; Cook, D. J.; Ely, E. W.; Epstein, S. K.; Fink, J. B.; Heffner, J. E.; Hess, D.; Hubmayer, R. D.; Scheinhorn, D. J.; American College of Chest Physicians; American Association for Respiratory Care; American College of Critical Care Medicine. Evidence-Based Guidelines for Weaning and Discontinuing Ventilatory Support: A Collective Task Force Facilitated by the American College of Chest Physicians; the American Association for Respiratory Care; and the American College of Critical Care Medicine. Chest2001, 120 (6 Suppl), 375S-95S.

9. Liu, J.; Shen, F.; Teboul, J.-L.; Anguel, N.; Beurton, A.; Bezaz, N.; Richard, C.; Monnet, X. Cardiac Dysfunction Induced by Weaning from Mechanical Ventilation: Incidence, Risk Factors, and Effects of Fluid Removal. Crit. Care2016, 20 (1)

\title{
ĐĂC ĐIỂM Nô̂I SOI ĐƯờ'NG HÔ HẤP TRÊN TRONG GIẤC NGỦ TAO RA BẰNG THUỐC TRONG HộI CHỨNG NGỪNG THỞ TẮC NGHẼN KHI NGỦ
}

\author{
Trần Thị Hoa' ${ }^{1}$ Pham Trần Anh ${ }^{1}$, \\ Nguyễn Trung Anh ${ }^{2}$, Đào Đình Thi ${ }^{3}$, Nguyễn Nhật Linh ${ }^{3}$
}

\section{TÓM TẮT}

Mục tiêu: Mô tả đặc điểm đường hô hấp trên trong hội chứng ngừng thở tắc nghẽn khi ngủ. Phương pháp: Nghiên cứu in vivo, người đánh giá độc lập, thực hiện trên 12 bệnh nhân có mắc hội chứng ngừng thở tắc nghẽn khi ngủ mức độ năng qua đo đa ký giấc ngủ. Tất cả mẫu nghiên cứu được nội soi đường hô hấp trên bằng ống nội soi mềm qua đường mũi trong giấc ngủ được tạo ra bằng thuốc gây mê. Đánh giá vị trí, cấu hình xẹp và mức độ xẹp theo phân loại VOTE của Kerizian và cộng sự năm 2011 [1]. Kết quả: Mô tả đặc điểm DIŚE ở 12 bênh nhân ngừng thở tắc nghẽn khi ngủ mức độ nặng (có chỉ số AHI 53.18 $\pm 15.75 /$ giờ, Chỉ số khối cở thể $25.33 \pm 1.95$ $\mathrm{kg} / \mathrm{m}(2)$, tuổi $45.75 \pm 13.53$ tuổi, tỷ lệ nữ:nam là 1:2) trước khi lựa chon kế hoach phẫu thuật. Qua phân tích có tới 7 bệnh nhân (58.3\%) có xẹp nhiêu hơn một tầng tại đường hô hấp trên và bệnh nhân xẹp đa tầng

\footnotetext{
1 Trường Đại hoc Y Hà Nôi

²Bênh viên Lão khoa Trung Uơng

${ }^{3}$ Bềnh viện Tai Mũi Họng Trung Ương

Chịu trách nhiệm chính: Trần Thị Hoa

Email: hoatran95.hmu@gmail.com

Ngày nhận bài: 21.6.2021

Ngày phản biên khoa hoc: 18.8.2021

Ngày duyệt bài: 26.8.2021
}

có chỉ số $A H I$ và BMI cao hơn bênh nhân xẹp đơn tânng có ý nghĩa thống kê với $\mathrm{p}<0.05$ (56.54 16.67 so với $51.64 \pm 16.39$ và $25.83 \pm 1.75$ so với $24.98 \pm 2.14$ ) và các vị trí xẹp nắp thanh thiệt hay xẹp họng miệng, màn hầu, đáy lưỡi có chỉ số ẢHI khác biệt và sự khác biệt về tuổi và chênh lệch giới giữa nhóm bệnh nhân xẹp đa tầng và đơn tầng không có ý nghĩa thống kê (p>0.05). Kết luận: Việc thực hiện DISE phát hiện tỷ lệ xẹp đa tầng tại đường hồ hấp trên ở bệnh nhân ngừng thở tắc nghẽn mức độ nặng là cao. Do vậy, chúng tôi đề xuất DISE là công cụ lựa chọn đánh giá đường hô hấp trên cho những bệnh nhân ngừng thở tắc nghẽn mức độ nặng có chỉ định phẫu thuật.

Tư khóa: Nôi soi đường thở khi ngủ, phẫu thuât hội chứng ngừng thở tắc nghẽn khi ngủ, đánh giá đường hô hâp trên khi ngủ, thuốc trong nội soi.

\section{SUMMARY}

\section{DRUG INDUCED SLEEP ENDOSCOPY IN} OBSTRUCTIVE SLEEP APNEA SYNDROME

Objectives: Upper airway characteristics in obstructive sleep apnea syndrome. Methods: In vivo study performed on 12 patients with severe OSA syndrome in PSG. All objects underwent upper airway endoscopy with a soft trans-nasal endoscope during sleep induced with the anesthetic. Evaluation of the location, profile and degree of collapse according to the VOTE classification of Kerizian et al 2011[1] 
Results: The mean index of AHI $53.18 \pm 15.75 / h$, BMI $25.33 \pm 1.95 \mathrm{~kg} / \mathrm{m}(2)$, Age $45.75 \pm 13.53$ year old. After analysis, up to 7 patients $(58.3 \%)$ had more than one stage collapse in the upper airway and multistage collapse had a statistically significant higher AHI and BMI than single-stage collapse with $p<0.05$ (56.54 \pm 16.67 compared with $51.64 \pm 16.39$ and $25.83 \pm 1.75$ compared with $24.98 \pm 2.14$ ) and the sites of epiglottis cartilage collapse or collapse of the pharynx, pharynx, and bottom of the tongue had no significant difference in $\mathrm{AHI}$ index and the difference in age and gender difference between the group of patients with multistage and single-stage collapse was not statistically significant ( $p>0.05)$. Conclusion: The implementation of DISE found a high rate of multistage collapse of the upper airway in patients with severe obstructive apnea. Therefore, we recommend DISE as the tool of choice for upper airway assessment in patients with severe obstructive sleep apnea who are indicated for surgery.

Key words: DISE, OSAS surgery, assessment of the upper airway during sleep, endoscopic medication.

\section{I. ĐĂT VẤN ĐỀ}

Hội chứng ngừng thở tắc nghẽn khi ngủ là một rối loạn hô hấp trên liên quan đến giấc ngủ hay gặp nhất, được xác định là sự xuất hiện các cơn ngừng thở và giảm thở tái diến do tắc nghẽn đường hô hấp trên trong khi ngủ, đặc trưng bởi sự xẹp tái diễn của đường hô hấp trên trong khi ngủ.

Hội chứng này rất thường gặp và ngày càng có xu hướng tăng lên và để lại nhiều hậu quả nghiêm trọng. Nguyên nhân của nó xuất phát từ sự phụ thuộc lẫn nhau của cấu trúc giải phẫu đường hô hấp trên tương tác với cơ chế sinh lý trong sự bất ổn của đường thở trong khi ngủ. Và một loạt các rối loạn chức năng hầu họng được tìm thẩy trong OSA nên việc đánh giá vị trí tắc nghẽn và mức độ nghiêm trọng ở bệnh nhân OSA là vô cùng quan trong để lựa chon phương pháp điều trị. Việc xác định các vị trí, mức độ nghiêm trọng và kiểu tắc nghẽn của đường hổ hấp trên trong hội chứng ngừng thở tắc nghẽn khi ngủ là rất quan trọng để lựa chọn điều trị, đặc biệt là lựa chọn kế hoạch phẫu thuật.

Gần đây, nội soi đường hô hấp trên trong giấc ngủ gây ra bằng thuốc (DISE) đã được giới thiệu như một công cụ chẩn đoán và đánh giá hữu ích cho phép xác định tình trạng xẹp đường hô hấp trên một cách toàn diên trong khi dùng thuốc an thần nhằm tạo ra giấc ngủ tư nhiên. Trong bài viết này, chúng tôi sẽ giới thiệu phương pháp bao gồm các chỉ định, kỹ thuật, hệ thống phân loại vị trí tắc nghẽn đường hồ hấp trên và ứng dunng trong lựa chon điều trị. Mặc dù các phương pháp điều trị như thay đổi lối sống, giảm cân, thở máy áp lực dương liên tục khi ngủ đã được nghiên cứu và áp dụng, cho thây hiệu quả rõ rệt đến việc cải thiện triệu chứng lâm sàng và các chỉ số ngừng thở, giảm thở trong giấc ngủ [2],[3] và đến nay, PAP được cho là phương pháp điều trị hiệu quả nhất nhưng cho thấy vấn đề về tuân thủ điều trị khó. Vì thế, các phương pháp điều trị phẫu thuật liên quan đến các bất thường về đường hô hấp trên ngày càng khẳng định vai trò và ứng dụng hiệu quả ở một số nhóm bệnh nhân có bất thường về giải phẫu rõ ràng hoăc muốn được điều trị bằng phẫu thuât ngay lập tức. Ở những bênh nhân đó, bắt buộc phải đánh giá mức độ tắc nghẽn của đường thở khi ngủ.

Một số kỹ thuật đánh giá đường thở đã được đề xuất, bao gồm khám lâm sàng với nghiệm pháp Muller, đo đường kính sọ mặt, chụp cắt lớp vi tính (CT), cộng hưởng từ (MRI), nội soi đường thở trong giấc ngủ do thuốc gây ra (DISE). Mặc dù các phương pháp đánh giá ban đầu, chẳng hạn như nghiệm pháp Muller, $\mathrm{CT}$, và MRI được sử dụng để đánh giá vị trí tắc nghẽn thực hiện khi bệnh nhân thức, nhưng như đã nói sự khác biệt về sinh lý và giải phẫu giữa bệnh nhân thức và ngủ cho thấy khả năng đánh giá hạn chế. Khắc phục hạn chế này, công cụ DISE có thể được sử dụng khi dùng thuốc an thần tạo ra giấc ngủ tương tự giấc ngủ tự nhiên.

Gần đây, hầu hết các bác sĩ phẫu thuật OSA đã sử dụng DISE để xác định lựa chọn phẫu thuật. Vì việc quan sát vị trí xẹp trong khi ngủ là cần thiết để xác định chính xác vị trí cần phẫu thuật, Croft và Pringle đề xuất đâuu tiên "Nội soi ống mềm khi ngủ" để đánh giá bênh nhân OSA vào năm 1991 [4]. Nhưng vì cần tác nhân dược lý để đưa bệnh nhân và giấc ngủ, Kerzirian và Hohenhorst đã thay đổi danh pháp thành "Nội soi đường thở trong giấc ngủ tạo ra do thuốc" [1]. Trái ngược với các quy trình trước đây thường cung cấp các đánh giá hai chiều ở trạng thái người bệnh ngồi thẳng và tỉnh táo, phương pháp DISE cung cấp các đánh giá ba chiều về đường hô hấp trên trong quá trình an thần mô phỏng giấc ngủ tự nhiên.

\section{II. ĐỐI TƯƠNG VÀ PHƯƠNG PHÁP NGHIÊN CỨU}

2.1. Đối tượng nghiên cứu: 12 bệnh nhân trên 18 tuổi được chẩn đoán ngừng thở tắc nghẽn khi ngủ mức độ nặng và được nội soi đường hô hấp trên trong giấc ngủ gây ra do thuốc tại bệnh viện Tai Mũi Họng Trung Ương từ tháng 08/2020 đển tháng 07/ 2021.

Tiêu chuẩn chơn mấu. Bệnh nhân từ đủ 18 tuổi trở lên, và có ít nhất một bất thường giải phẫu chẩn đoán bằng nội soi tai mũi họng khi thức và đồng ý tham gia nghiên cứu. 
Tiêu chuẩn loai trư. Loại trừ mẫu nghiên cứu nếu có một trong các tiêu chuẩn: bệnh nhân chẩn đoán OSA nhe hoặc trung bình; bệnh nhân đã điều trị can thiệp phẫu thuật vào đường hô hấp trên; bệnh nhẩn không có bất kỳ nghi ngờ bất thường nào trong thăm khám mũi họng khi thức; Bệnh nhân được chẩn đoán họ̣i chứng ngừng thở khi ngủ trung ương hoặc mắc các rối loạn giấc ngủ khác; bệnh nhân không đủ tiêu chuẩn làm thăm dò chẩn đoán các rối loạn giấc ngủ do đang bị bệnh cấp tính, đợt cấp của các bệnh mạn tính, bệnh nhân suy hô hấp, suy tuần hoàn...; Bệnh nhân rối loạn tâm thần không hợp tác; Bệnh nhân không đồng ý tham gia nghiên cứu

\subsection{Phương pháp nghiên cứu}

Thiết kế nghiên cứu: Nghiên cứu in vivo, mô tả cắt ngang, người đánh giá độc lập.

Đa ký giấc ngủ: Kiểm tra 18 kênh dữ liệu theo Hiệp hội giấc ngủ Hoa Kỳ (AASM 2007). Xác định cơn ngừng thở khi thỏa mãn: $a$, có giảm từ $90 \%$ trở lên biên đô đường ghi tín hiêu của cảm biến nhiệt so với biên độ đường cơ bản trước khi xảy ra sự kiện; b, thời gian của sự giảm biên độ nói trên kéo dài ít nhất là 10 giây. Xác định cơn giảm thở khi thỏa mãn: a, có giảm từ 30\% biên độ đường tín hiệu dòng khí thở qua mũi so với biên độ đường cơ bản trước khi xảy ra sự kiện; $b$, thời gian của sự giảm biên độ nói trên kéo dài ít nhất 10 giây; c, có giảm từ 3\% trở lên độ bão hòa oxy máu so với độ bão hòa oxy máu nền trước đó hoặc sự kiện đi kèm với một thức giấc.

Nội soi đường thở trong giấc ngủ gây ra

\section{bằng thuốc:}

- Địa điểm và công cụ: Thực hiện gây mê trong phòng mổ và có sự theo dõi của bác sỹ gây mê hồi sức. Nhiệt độ phòng dễ chịu, môi trường yên tĩnh và đèn mờ rất hữu ích để tạo giấc ngủ tự nhiên. Độ bão hòa oxy, nhịp tim và huyết áp phải được theo dõi trong suốt quá trình phấu thuật và phải chuẩn bị oxy bổ sung trong trường hợp khẩn cấp. Đô sâu của thuốc an thần được đánh giá bằng tình trạng mất ý thức, bắt đâu ngáy và rối loạn nhịp thở.

- Chuẩn bị bệnh nhân: Nhịn ăn uống; dùng thuốc kháng cholinergic như atropine, glycopyrrolate trước 30 phút để giảm tiết nước bọt giúp có trường nhìn tốt khi nội soi và giảm ho sặc; đặt co mạch mũi 1 hoặc 2 bên; nội soi trước khi gây ngủ để kiểm tra tình trạng đáp ứng vô cảm.

- Thuốc: Các thuốc được sử dụng để gây ngủ thực chất làm giảm trương lực cơ họng và để làm giảm nguy cơ tắc nghẽn đường thở hoàn toàn cần có sự can thiệp bảo vệ đường thở.
Nhiều loại thuốc ngủ được dùng trong nội soi như là propofol, midazolam, dexmedetomidine, và opioids. Trong đó Propofol (2-6diisopropylphenol) và midazolam (benzodiazepine) hay được sử dụng nhất. Propofol là thuốc gây ngủ tác dụng ngắn, cơ chế hoạt động của Propofol thông qua ức chế GABA và tạo sóng chậm trên điện não đồ trong giai đoạn NREM. Midazolam là loại benzodiazepine hoạt hóa ngắn tác dụng làm giảm tần suất mơ kênh GABA và làm giãn cơ hầu họng nhiều hơn Propofol. Áp lực cơ vùng hầu họng dưới tác dụng của Propofol và Midazolam tương tự áp lực cơ trong giai đoạn NREM của giấc ngủ $[5,6,7,8]$. Trong nghiên cứu của chúng tôi, chúng tôi sử dụng propofol vì những ưu điểm: tác dụng nhanh, ngắn an toàn; ít tác dụng giãn cơ; tạo được một giấc ngủ gần giống giấc ngủ tự nhiển và dễ dàng phát hiện khi quá liêu thuốc. Sau khi nội soi, bệnh nhân có thể tỉnh lại sớm, rút ngắn thời gian giải mê. Chúng tôi đã sử dụng liều 2 $\mathrm{mg} / \mathrm{kg}$ cân nặng, bắt đầu $1 \mathrm{mg} / \mathrm{kg}$, và tăng dần 50-100 $\mathrm{ml} / \mathrm{h}$ đến khi đạt được trang thái ngủ.

Đánh giá. Có nhiều phân loại đã được sử dụng để mô tả DISE. Năm 2019, Ảhmed và cộng sự đã sử dụng Phân loại LwPTL. Nghiên cứu của chúng tôi sử dụng phẩn loại VOTE vì đánh giá được 4 vị trí hay gặp nhất ở hầu hết các bệnh nhẩn: Velum-m àn hầu, Oropharyngeal latera walls-thành bên họng miệng, Tongue base-đáy Iưỡi, Epiglottis- nắp thanh thiệt và VOTE không chỉ xác định vị vị trí tắc nghẽn mà còn xác định mức độ tắc nghẽn và cấu hình (tức là, tắc nghẽn theo các hướng trước-sau, bên hoặc trung tâm).

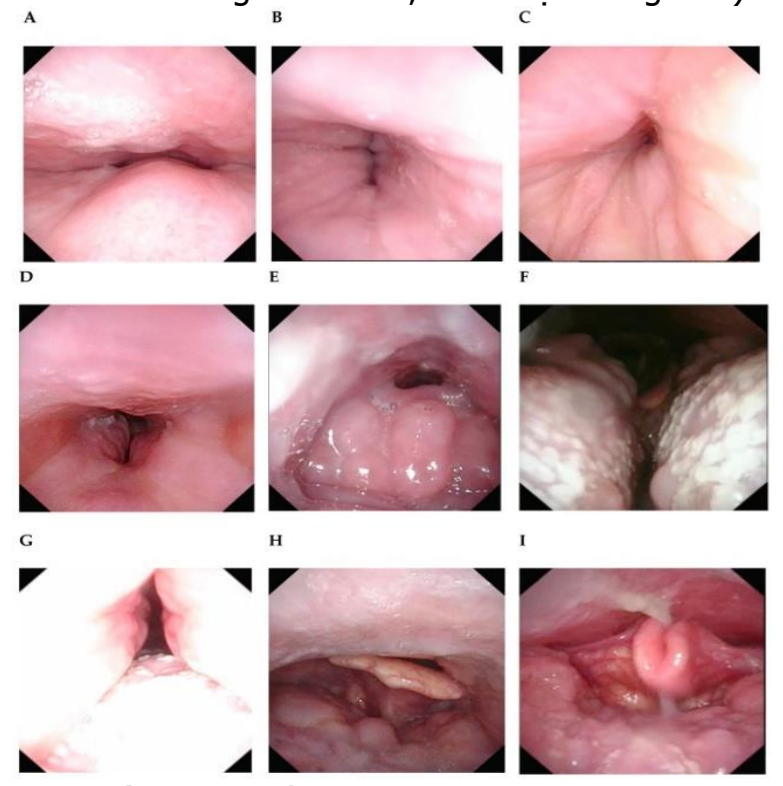

Hình 1: Phân loại VOTE trong DISE 
Xử lý kết quả. Số liệu nghiên cứu được xử lí và phân tích bằng phần mềm thống kề SPSS 16.0. Các biến định lượng được thể hiện dưới dạng số trung bình và độ lệch chuẩn.

Đạo đức nghiên cứu: Nghiên cứu được chấp thuận của Hội đồng Đạo đức Nghiên cứu trường Đại học Y Hà Nội

\section{KẾT QUẢ NGHIÊN CứU}

Trong khoảng thời gian từ tháng 08/2020 đến tháng $07 / 2021$, chúng tôi đã nội soi đường hô hấp trên trên 12 bệnh nhân thỏa các điều kiện tham gia nghiên cứu. Trong đó tỷ lệ nữ:nam là $1: 2$. Tuổi bệnh nhân trung bình $45.75 \pm 13.53$ tuổi, nhỏ nhất là 21 tuổi, lớn nhất là 67 tuổi, chỉ số khối trung bình là $25.33 \pm 1.95 \mathrm{~kg} / \mathrm{m} 2$, chỉ số AHI trung bình là $53.18 \pm 15.75 /$ giờ.

Qua phân tích tất cả các bệnh nhân nghiên cứu đều có ít nhất một vị trí xẹp hoàn toàn. Có tới 7 bệnh nhân (chiếm tỷ lệ $58.3 \%$ ) có xẹp nhiều hơn một tầng tại đường hổ hấp trên (Biểu đồ 1).

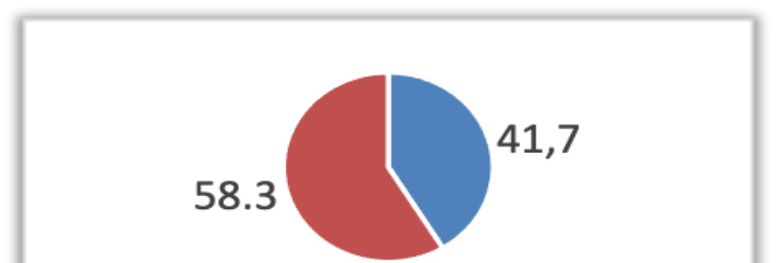

\section{- Sập đơn tầng = Sập đa tầng}

\section{Biểu đồ 1. Phân bố đặc điểm xẹp đường hô hâp trên}

Đa số bệnh nhân có vị trí tắc nghẽn tại eo họng (chiếm tỷ lệ $83,3 \%$ ), tiếp theo là màn hầu $(58.3 \%)$, nắp thanh thiêt $(25 \%)$ và đáy lưỡi $(16,7 \%)$. Tắc nghẽn phối hợp eo họng - màn hầu chiếm tỷ lệ cao $(41,7 \%)$, tiếp theo là phối hợp màn hầu - nắp thanh thiệt (25\%). Rất ít bệnh nhân tắc nghẽn phối hợp tại nắp thanh thiệt- màn hầu - eo họng (16.7\%) và tại đáy lưỡi - nắp thanh thiệt hay nắp thanh thiệt - đáy lưỡi - màn hâu (cùng chiếm $8,3 \%$ ). Tỷ lệ bệnh nhân phối hợp 3 tầng: gồm xẹp eo họng-đáy lưỡi-nắp thanh thiệt và màn hầu-eo họng-nắp thanh thiệt cao (25\%). Không có bệnh nhân nào xẹp tại 2 vị trí eo họng - đáy lưỡi hoặc 3 vị trí như màn hầu - eo họng - đáy lưỡi, eo họng đáy lưỡi - nắp thanh thiệt (Biểu đồ 2)

Bệnh nhân xẹp đa tầng có chỉ số $\mathrm{AHI}$ và $\mathrm{BMI}$ cao hơn bệnh nhân xẹp đơn tầng có ý nghĩa thống kê với $p=0.02<0.05$ (56.54 $\pm 16.67, n=7$ so với $51.64 \pm 16.39, \mathrm{n}=5$ và $25.83 \pm 1.75$ so với
24.98 2.14) và chỉ số AHI trung bình ở các vị trí tắc nghẽn đường thở có sự khác biệt: $\mathrm{AHI}$ cao nhất ở vị trí tắc nghẽn tại eo họng $(54,45 \pm 15,22)$, tiếp theo là nắp thanh thiệt và màn hầu (lần lượt là 49,77 $\pm 14,79,47,2 \pm 15,02$ ), thấp nhất là tại vị trị đáy lưỡi $(34,85 \pm 1,2)$. Sự khác biệt này không có ý nghĩa thống kề $(p=0.67>0,05)$.

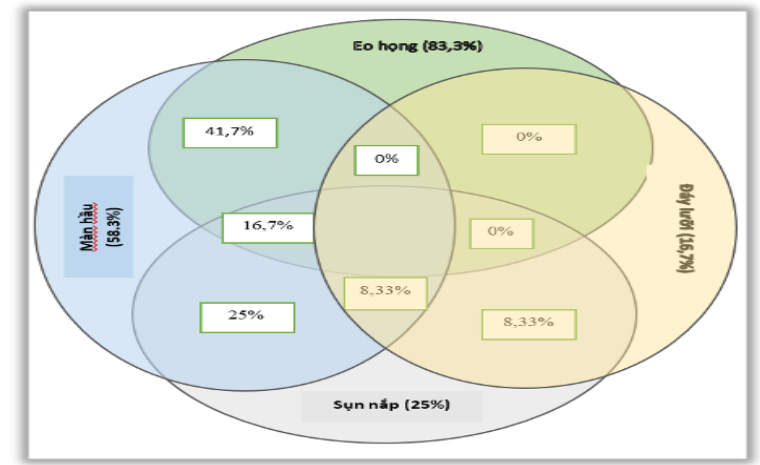

Biểu đồ 2: Phân bố vị trí hẹp trên đường hô hâp trên

Sự khác biệt về tuổi và chênh lệch giới giữa nhóm bệnh nhân xẹp đa tầng và đơn tầng không có ý nghĩa thống kề ( $p>0.05)$. (Bảng 1)

Bảng 1: Đặc điểm chung của nhóm đôi tượng có tắc nghẽn đường thơ

\begin{tabular}{|c|c|c|c|c|}
\hline Nhóm & $\begin{array}{c}\text { Chỉ số } \\
\text { AHI } \\
\text { trung } \\
\text { bình }\end{array}$ & $\begin{array}{c}\text { BMI } \\
\text { trung } \\
\text { bình } \\
(\mathrm{kg} / \mathrm{m} 2)\end{array}$ & Tuổi & $\begin{array}{c}\text { Giới } \\
\left(\begin{array}{c}\mathbf{N a m} / \\
\mathbf{N u ̛ ́})\end{array}\right.\end{array}$ \\
\hline $\begin{array}{l}\text { Xepp đơn } \\
\text { tâng }(n=7)\end{array}$ & $\begin{array}{c}51,64 \\
\pm 16,39 \\
\end{array}$ & $\begin{array}{l}24,98 \\
\pm 2,14\end{array}$ & \begin{tabular}{|c|}
43,14 \\
$\pm 14,44$ \\
\end{tabular} & $4 / 1$ \\
\hline $\begin{array}{c}\text { Xẹp đa } \\
\text { tầng }(n=5)\end{array}$ & $\begin{array}{c}56,54 \\
\pm 16,67\end{array}$ & $\begin{array}{l}25,83 \\
\pm 1,75\end{array}$ & \begin{tabular}{|c|}
49,4 \\
$\pm 12,74$ \\
\end{tabular} & $4 / 3$ \\
\hline $\begin{array}{c}\text { Tống } \\
(\mathrm{N}=12)\end{array}$ & $\begin{array}{c}53,18 \\
\pm 15,75 \\
\end{array}$ & $\begin{array}{l}25.33 \\
\pm 1.95 \\
\end{array}$ & $\begin{array}{c}45,75 \pm \\
13,53 \\
\end{array}$ & $8 / 4$ \\
\hline p & 0,002 & 0,001 & 0,67 & - \\
\hline
\end{tabular}

Trong nghiên cứu của chúng tôi, sự phân bố tắc nghẽn đường thở trên theo các cấu hình và vị trí có đặc điểm khác nhau. Tại vị trí màn hầu đa số không tắc nghẽn (chiếm 41,6\%), và tỷ lệ các cấu hình tắc nghẽn đường thở trên khá đồng đều nhau (từ 16,7\% đến 25\%). Tại vị trí eo họng, không ghi nhận trường hợp tắc nghẽn theo cấu hình trung tâm hay trước sau, cấu hình tắc nghẽn tại eo họng phía bên chiếm tỷ lệ cao (chiếm $83,3 \%$ ). Tại vị trí đáy lưỡi và nắp thanh thiệt đa số không tắc nghẽn (lần lượt chiếm $83,3 \%$ và $75 \%$ ), không ghi nhận trường hợp cấu hình tắc nghẽn trung tâm và bên, cấu hình tắc nghẽn trước sau chiếm tỉ lệ cao (lần lượt 16,7\% và $25 \%)$. (Bảng 2 ). 
Bảng 2: Phân bố tắc nghẽn đường thở theo hướng và vị trí tắc nghẽn $(N=12)$

\begin{tabular}{|c|c|c|c|c|}
\hline Vị trí & $\begin{array}{c}\text { Màn } \\
\text { hâu } \\
\text { n(\%) }\end{array}$ & $\begin{array}{c}\text { Eo } \\
\text { hông } \\
\text { nơnt }\end{array}$ & $\begin{array}{c}\text { Đáy } \\
\text { lưỡi } \\
\text { n(\%) }\end{array}$ & $\begin{array}{c}\text { Sựn } \\
\text { nắp } \\
\text { n(\%) }\end{array}$ \\
\hline Trước-sau & $3(25)$ & 0 & $2(16,7)$ & $3(25)$ \\
\hline Trung tâm & $2(16,7)$ & 0 & 0 & 0 \\
\hline Bên & $2(16,7)$ & $10(83,3)$ & 0 & 0 \\
\hline Không & $5(41,6)$ & $2(16,7)$ & $10(83,3)$ & $9(75)$ \\
\hline
\end{tabular}

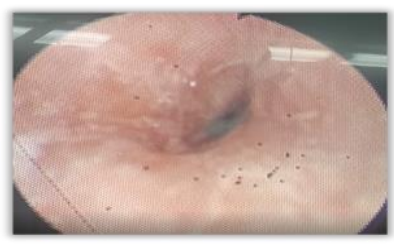

Hình 4: Xẹp màn hầu kiểu bên.

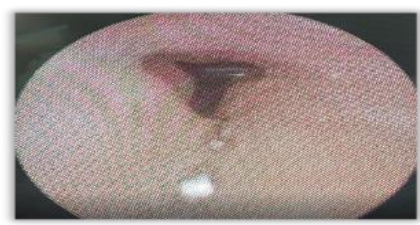

Hinh 5: Xep hoàn toàn eo họng kiêu bên.

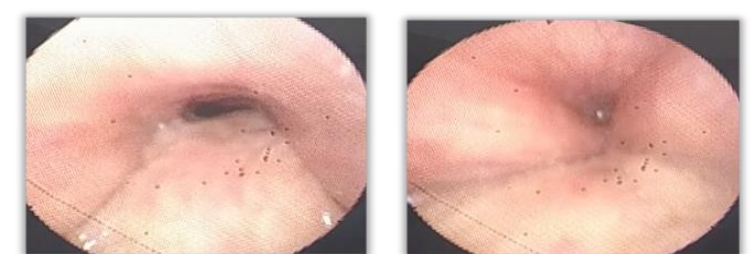

Hình 2: Xep màn hầu Hình 3: Xep màn hầu kiểu trước sau. kiểu trung tâm.

\section{BÀN LUẬN}

Nghiên cứu của chúng tôi mô tả đặc điểm đường hô hấp trên ở những bệnh nhân ngừng thở tắc nghẽn khi ngủ mức độ nắng và có ít nhất một bất thường thuộc nguyên nhân tai mũi họng. Kết quả chỉ ra rằng có rất nhiều bệnh nhân có xẹp ở nhiều vị trí trên đường hô hấp trên mà không phải chỉ 1 vị trí đơn độc. Xẹp đa tầng trong nghiên cứu của chúng tôi là $58.3 \%$ thấp hơn nghiên cứu của Vanderveken $\mathrm{OM}$ là 91\% [9]. Trong nghiên cứu của chúng tôi bệnh nhân có xẹp đa tầng có chỉ số $\mathrm{AHI}$ và $\mathrm{BMI}$ cao hơn nhóm xẹp chỉ 1 tầng $(56.54 \pm 16.67, \mathrm{n}=7$ so với $51.64 \pm 16.39, \mathrm{n}=5$ và $25.83 \pm 1.75$ so với 24.98 \pm 2.14$)$ cho thây những bệnh nhân ngừng thở tắc nghẽn mức độ nặng có chỉ số $\mathrm{AHI}$ và $\mathrm{BMI}$ càng cao thì càng có nguy cơ bị xẹp đa tầng.

Vi trí xẹp đường hô hấp trên ở eo hong chiếm tỷ lệ cao nhất, xếp thứ 2 là tại màn hầu. Điều này khác với những nghiên cứu trước, theo Vanderveken $\mathrm{OM}$ là màn hầu hay gặp nhất và xếp thứ 2 là đáy lưỡi [9]

Hiên nay tiềm năng về kết quả điều trị trong các lựa chọn điều trị ngừng thở tắc nghẽn khi ngủ ngoài CPAP đang rất được quan tâm nên DISE cung cấp một phương tiện để nghiên cứu đường hô hấp trên ở những bệnh nhân ngừng thở tắc nghẽn khi ngủ. Hạn chế của DISE nói chung và nghiên cứu của chúng tôi nói riêng là: thứ nhất, chưa thống nhất phác đồ sử dụng thuốc gây ngủ giữa các nghiên cứu; thứ 2, việc đánh giá đường hô hấp khi nội soi mang tính chủ quan và đòi hỏi những nhà tai mũi họng có kinh nghiệm; thứ 3, DISE chỉ được đánh giá ở tư thế nằm ngửa trong khi lý tưởng nhất là các cấu hình xẹp trên đường hô hấp nên được đánh giá ở cả tư thế nằm ngửa, nằm sấp và ngồi.

\section{KẾT LUẦN}

Tuổi trung bình của nhóm nghiên cứu là $45.75 \pm 13.53$ tuổi, lớn nhất là 67 tuổi, nhỏ nhất là 21 tuổi. Tỷ lệ giới tính nữ: nam là $1: 2$ và chỉ sô ngừng thở giảm thở trung bình là $53.18 \pm 15.75 /$ giờ, thấp nhất là $34 /$ giờ, cao nhất

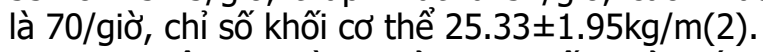

Trong nội soi đường thở trong giấc ngủ chúng tôi thấy tất cả các bệnh nhân nghiên cứu đều có bất thường xẹp ít nhất 1 vị trí tại đường hô hấp trên. Tỷ lệ xẹp đa tầng (xẹp nhiều hơn một vị trí) là $58.3 \%$. Tỷ lệ bênh nhân xẹp eo họng là $83,3 \%$, xep màn hầu là $58.3 \%$, xẹp nắp thanh thiệt là $25 \%$ và xẹp đáy lưỡi $16,7 \%$. Vị trí xẹp phối hợp eo họng - màn hầu chiếm tỷ lệ cao là $41,7 \%$, vị trí xẹp phối hợp màn hầu - nắp thanh thiệt là $25 \%$ và xẹp đáy lưỡi - nắp thanh thiệt là $8.3 \%$. Tỷ lệ bệnh nhân xẹp 3 tâng màn hâu - eo hong - nắp thanh thiệt là $16.7 \%$ và xẹp màn hẩu - đáy lưỡi - nắp thanh thiệt là 8,3\%.

Kết luận, dựa trên kết quả của nghiên cứu được báo cáo, DISE có thể được đề xuất là một công cụ nghiên cứu đường hổ hấp trên để để điều trị OSA. Để phân tích sâu hơn về giá trị của DISE trong việc lựa họn phẫu thuật và đánh giá đáp ứng điều trị cần được thực hiện trong các thử nghiệm đa trung tâm lớn hơn và hiện đang được tiến hành.

\section{TÀI LIÊU THAM KHẢO}

1. Kezirian EJ, Hohenhorst $W$, de Vries N (2011). Drug-induced sleep endoscopy: the VOTE classification. Eur Arch Otorhinolaryngol. 2011;268:1233.

2. SeppäJM Tuomilehto HP, Partinen MM, et al (2009). Lifestyle intervention with weight reduction: first-line treatment in mild obstructive 
sleep apnea. American Journal Respiratory Critical Care Medicine, 179(4):320.

3. Zaghi S Certal VF, Riaz M, et al (2015). Hypoglossal nerve stimulation in the treatment of obstructive sleep apnea: A systematic review and meta-analysis. Laryngoscope, 125, 1254-1264.

4. Blumen $M$, Bequignon $E$, Chabolle $F$ (2017). Drug-induced sleep endoscopy: A new gold standard for evaluating OSAS? Part I: Technique. Eur Ann Otorhinolaryngol Head Neck Dis. 2017 Apr;134(2):101-107

5. Dempsey JA, Veasey SC, Morgan BJ, O'Donnel CP (2010). Pathophysiology of sleep apnea. Physiol Rev. 2010;90:47

6. Salam O. Salman, 2019 Modern Management of
Obstructive Sleep Apnea.

7. Kushida C Li KK, Powell NB, et al (2000). Obstructive sleep apnea syndrome: a comparison between Far-East Asian and white men. Laryngoscope, 110, 1689-1693.

8. Palta M Young T, Dempsey J, et al (2009). Burden of sleep apnea: rationale, design, and major findings of the Wisconsin Sleep Cohort study. Wisconsin Medical Journal, 108(5), 246-249

9. Vanderveken OM, Maurer JT, Hohenhorst W, et al (2013) Evaluation of drug-induced sleep endoscopy as a patient selection tool for implanted upper airway stimulation for obstructive sleep apnea. J Clin Sleep Med. 2013;9(5):433-438.

\section{KHẢO SÁT NỒNG Độ C - PEPTIDE VÀ MỐI LIÊN QUAN VỚI BIẾN CHỨNG VI MẠCH Ở BỂNH NHÂN ĐÁI THÁO ĐƯỜNG TYPE 2}

\section{TÓM TẮT}

C - Peptide là một polypeptide được tiết racùng lúc và với môt lượng tương đương với insulintừ tế bào beta tụy. Việc xét nghiệm nồng độ $C$ - Peptide lúc đói có thể cho chúng ta biết được lượng insulin nội sinh ở bênh nhân đái tháo đường... Mục tiêu: Khảo sát nồng độ $C$ - Peptide và mối liên quan với biến chứng võng mạc mắt và albumin niệu ở bệnh nhân đái tháo đường type 2. Đối tượng và phương pháp: nghiên cứu mô tả cắt ngang 87 bệnh nhân đái tháo đường type 2 khám tại Bệnh viện Bạch Mai từ tháng 01/2021 đến 8/2021. Kết quả: Nồng độ $C$ - Peptide lúc đói trung bình trên nhóm bệnh nhân nghiên cứu là: $0,83 \pm 0,35$ $\mathrm{nmol} / \mathrm{l}$. Nồng độ $\mathrm{C}$ - Peptide lúc đói có mối tương quan nghịch biến ở mức độ vừa phải với nồng độ albumin niệu $(r=-0,352, p=0,001$, spearman test). Nồng độ $C-$ Peptide lúc đói trên nhóm bệnh nhân có microalbumin niệu: $0,72 \pm 0,34 \mathrm{nmol} / \mathrm{l}$, nhóm không có microalbumin niệu: $0,88 \pm 0,35 \mathrm{nmol} / \mathrm{l}$, sự khác biệt có ý nghĩa thống kê với $p=0,047$. Nồng độ $C-$ Peptide lúc đói trên nhóm bệnh nhân có biển chứng võng mạc mắt: $0,72 \pm 0,33 \mathrm{nmol} / \mathrm{l}$, nhóm không có biến chứng võng mac mắt: $0,9 \pm 0,36 \mathrm{nmol} / \mathrm{l}$, sự khác biệt có ý nghĩa thổng kê với $p=0,041$. Kết luận: Nồng đô $C$ - Peptide lúc đói có mối tương quan nghich biến mức độ vừa phải với nồng độ albumin niệu. Nồng độ $C$ - Peptide lúc đói giảm có ý nghĩa thống kê trên nhóm bệnh nhân có biển chứng võng mạc mắt do đái tháo đường và nhóm bệnh nhân có tổn thương microalbumin niệu. Từ khóa: $\mathrm{C}-$ Peptide, biến chứng võng mạc mắt, microalbumin niệu.

\section{${ }^{1}$ Trường Đại Học Y Hà Nội}

${ }^{2}$ Bênh viên Bach Mai

Chịu trách nhiệm chính: Trần Mai Nguyên

Email: nguyentran.hmu0809@gmail.com

Ngày nhận bài: 21.6.2021

Ngày phản biện khoa học: 16.8.2021

Ngày duyệt bài: 25.8.2021
Trần Mai Nguyên ${ }^{1}$, Đỗ Trung Quân ${ }^{1,2}$

\section{SUMMARY \\ FASTING SERUM C - PEPTIDE IN TYPE 2 DIABETIC PATIENTS AND THE ASSOCIATION WITH MICROVASCULAR COMPLICATIONS}

C-Peptide is a polypeptide secreted simultaneously and in equimolar amounts with insulin from pancreatic beta cells. By measuring fasting serum C - Peptide, we can evaluate endogenous insulin reserve in diabetic patients. Aims: To survey on fasting serum $\mathrm{C}$ - Peptide and to comment on the association between fasting serum C - Peptide and diabetic retinopathy and urine albumin. Subjects and methods: crosssectional description study of 87 patients with a diagnosis of type 2 diabetes at Bach Mai Hospital from January 2021 to August 2021. Results: In this study, the mean value of fasting serum $C$ - Peptide is $0,83 \pm$ $0,35 \mathrm{nmol} / \mathrm{l}$. Negative correlation was seen between fasting serum $\mathrm{C}-$ Peptide and urine albumin level $(r=-$ $0,352, p=0,001$, spearman test). The mean values of fasting serum C-Peptide in patients with microalbuminuria and no microalbuminuriaare $0,72 \pm$ $0,34 \mathrm{nmol} / \mathrm{l}$ and $0,88 \pm 0,35 \mathrm{nmol} / \mathrm{l}$ respectively. Also in this study, the mean values of fasting serum $C$ Peptide in patients with diabetic retinopathy and no diabetic retinopathy are $0,72 \pm 0,33 \mathrm{nmol} / \mathrm{l}$ and $0,9 \pm$ $0,36 \mathrm{nmol} / \mathrm{l}$ respectively. Conclusion: The mean value of fasting serum $C$ - Peptide in this study is 0,83 $\pm 0,35 \mathrm{nmol} / \mathrm{l}$. The current study showed a significant correlation between fasting serum $\mathrm{C}$ - Peptide and urine albumin level. Fasting serum C - Peptide was significantly associated with diabetic retinopathy and microalbuminuria.

Keywords: Fasting serum C - Peptide , diabetic retinopathy, microalbuminuria.

\section{I. ĐĂT VẤN ĐỀ}

Đái tháo đường (ĐTÐ) hiện nay là một bệnh phổ biến và là mối quan tâm của tất cả các quốc gia trên thế giới bởi sự tăng lên nhanh chóng về 
số người mắc bênh cũng như các biến chứng nghiêm trọng của nó. Trong đó, các biến chứng trên hệ thống tim mạch đặc biệt là biến chứng liên quan đến vi mạch như bệnh võng mạc đái tháo đường (BVMĐTĐ) hay bệnh thận ĐTÐ chiếm phần lớn. Nguy cơ đe dọa do BVMĐTĐ và bệnh thận ĐTÐ là rất cao, làm ảnh hưởng đên kinh tế, tinh thần và chất lượng cuộc sông của người bênh. Việc phát hiện sớm các tổn thương mắt, thận trên bệnh nhần ĐTÐ có vai trò vô cùng quan trong. Microalbumin niệu (MAU) được coi là một yếu tố dự đoán biến chứng thận sớm ở bệnh nhân ĐTÐ. Chụp đáy mắt là một phương pháp phát hiện các tổn thương võng mạc ĐTĐ.

C - Peptide là một polypeptide gôm 31 acid amin được sản xuất từ tế bào beta tụy cùng một lúc và cùng một lượng với insulin từ sự phân hủy proinsulin. Do có thời gian bán hủy kéo dài hơn 4-5 lần, được bài tiết ở thận nguyên vẹn do vậy C - Peptide có khả năng đánh giá được chức năng của tế bào beta, tốt hơn insulin. Các biến chứng vi mạch trên bệnh nhân ĐTĐ type 2 thường có sự liên quan đến việc kiểm soát đường huyết không tốt. Thông qua $C$ - Peptide chúng ta có thể đánh giá được chức năng của tế bào beta tụy từ đó giúp mở ra hướng tiên lượng và điều trị mới liên quan đến biến chứng vi mạch trên bệnh nhân ĐTĐ type 2 . Trên thế giới, có nhiều nghiên cứu liên quan đến nồng độ $C$ Peptide và biến chứng vi mạch trên bệnh nhân ĐTĐ type 2 tuy nhiên ở Viêtt Nam, nghiển cứu về vấn đề này là chưa nhiều. Vì vậy chúng tôi tiến hành đề tài với mục tiêu "Khảo sát nồng độ $C$ Peptide và mối liên quan với biến chứng vi mạch trên bênh nhân đái tháo đường type 2".

\section{II. ĐỐI TƯỢNG VÀ PHƯƠNG PHÁP NGHIÊN CỨU}

1. Đối tượng nghiên cứu. Gồm 87 bệnh nhân được chẩn đoán đái tháo đường type 2 theo tiêu chuẩn của Tổ chức y tế thế giới (WHO) 2011 và Hiệp hội Đái tháo đường Hoa Kỳ (ADA) 2020. Loại trừ các trường hợp bệnh nhân dùng insulin hay thuốc sulfunylurea trong vòng 48 giờ và những bệnh nhân không đồng ý tham gia nghiên cứu.

*Thời gian nghiên cứu: từ tháng 1/2021 đến 8/2021.

*Địa điểm nghiên cứu: Khoa khám bệnh bênh viên Bach Mai.

\section{Phương pháp nghiên cứu}

*Thiêt kế nghiên cứu: Nghiên cứu mô tả cắt ngang, từ $1 / 2021$ đến $8 / 2021$

*Cỡ mâ̂u: Lây mẫu thuận tiện, toàn bộ bệnh nhân đái tháo đường type 2 đủ tiêu chuẩn trong thời gian nghiên cứu nói trên.
*Các chỉ tiêu nghiên cứu:

- Đặc điểm nhân trắc học: tuổi, giới, cân nặng, chiều cao.

- Đặc điểm cận lâm sàng:

o Nồng độ $C$ - Peptide lúc đói

- Microalbumin niệu (MAU): đánh giá qua mẫu nước tiểu ngẫu nhiên.

- Chụp đáy mắt: chụp hình cả hai đáy mắt không huỳnh quang.

- Phương pháp đánh giá:

- Chẩn đoán ĐTĐ typ 2 theo Hiệp hội Đái tháo đường Hoa Kỳ (ADA) 2020 và tiêu chuẩn của Tổ chức y tế thế giới (WHO) 2011.

- Tiêu chuẩn đánh giá tổn thương thận ĐTĐ. ${ }^{1}$

- Phân loại bệnh võng mạc mắt do ĐTÐ theo ETRDS (Early Treatment Diabetic Retinopathy Study).

- Chỉ số khối cơ thể (BMI): Theo tổ chức y tế thế giới (WHO) giành cho người châu Á.

*Xử lý và phân tích số liệu: các số liệu sau khi thu thập xử lý thống kê bằng phần mềm IBM SPSS Statistic 20.

*Đạo đức nghiên cứu: Đề tài đã được Hội đồng thông qua đề cươngTrường Đại học Y Hà Nội chấp thuận. Thông tin thu thập từ nghiên cứu được mã hóa, giữ kín và chỉ phục vụ cho mục tiêu nghiên cứu.

\section{KẾT QUẢ NGHIÊN CỨU}

\section{1. Đặc điểm chung của đối tượng nghiên} cứu

1.1. Đặc điểm về tuổi

Bảng 1. Phân bố tuổi của đôi tượng nghiên cứu $(n=87)$

\begin{tabular}{|c|c|c|c|}
\hline Phân bố tuối & $\mathbf{n}$ & $\mathbf{\%}$ & $\overline{x_{ \pm}} \mathbf{S D}$ \\
\hline Dưới 40 & 7 & 8,0 & $36,86 \pm 2,80$ \\
\hline $40-60$ & 58 & 66,7 & $51,79 \pm 5,77$ \\
\hline Trên 60 & 22 & 25,3 & $67,59 \pm 4,75$ \\
\hline Tống & 87 & 100 & $54,59 \pm 10,11$ \\
\hline
\end{tabular}

Nhận xét: Độ tuối trung bình của nhóm nghiên cứu là $54,59 \pm 10,11$. Bệnh nhân nhỏ tuổi nhất là 31 tuổi, bệnh nhân lớn tuổi nhất là 81 tuổi. Độ tuổi thường gặp nhất là từ $40-60$ tuổi (chiếm 66,7\%).

1.2 Đặc điểm về giới:

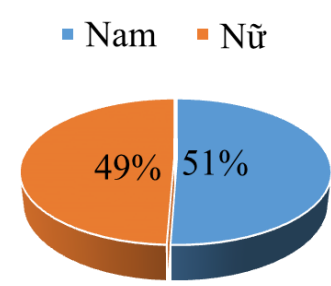

Biểu đồ 1. Phân bố đôi tướng theo giới

Nhận xét: Tỉ lệ nam: 50,6\%, nữ: 49,4\% như vậy tỉ lệ nam/nữ xấp xỉ 1:1. 
1.3 Phân bố đối tượng theo BMI

Bảng 2. phân bố đối tượng theo BMI $(n=87)$

\begin{tabular}{|c|c|c|}
\hline BMI & $\begin{array}{c}\text { Số BN } \\
\text { (n) }\end{array}$ & $\begin{array}{c}\text { Tỷ lệ } \\
\mathbf{( \% )}\end{array}$ \\
\hline Gày $(<18,5)$ & 3 & 3,4 \\
\hline Bình thường $(18,5-22,9)$ & 27 & 31,1 \\
\hline Thừa cân $(23-24,9)$ & 57 & 65,5 \\
\hline TB \pm SD & \multicolumn{2}{|c|}{$23,69 \pm 2,70$} \\
\hline
\end{tabular}

Nhận xét: Nhóm thừa cân, béo phì chiếm tì lệ cao nhất $(65,5 \%)$. Nhóm có BMI bình thường chiếm $31,1 \%$ và nhóm bệnh nhân gày chiếm tỉ lệ $3,4 \%$.

1.4 Tình trạng Microalbumin niệu của đôi tượng nghiên cứu

Bảng 3. Tỉ lệ có Microalbumin niệu trong nghiên cứu $(n=87)$

\begin{tabular}{|c|c|c|c|}
\hline Tỉ lệ MAU & $\mathbf{n}$ & $\mathbf{\%}$ & $\overline{\boldsymbol{x}} \mathbf{\pm S D}$ \\
\hline Không có MAU & 60 & 69 & $9,13 \pm 0,29$ \\
\hline Có MAU & 27 & 31 & $59,17 \pm 11,54$ \\
\hline Tống & $\mathbf{8 7}$ & $\mathbf{1 0 0}$ & $\mathbf{5 5 , 7 3 \pm 1 1 , 4 4}$ \\
\hline
\end{tabular}

Nhân xét: Tỉ lệ bênh nhân có Microalbumin niệu là $31 \%$, nhóm không cóMicroalbumin niệu chiếm $69 \%$.

\section{5 Đăc điểm BVMĐTÐ}

Bảng 4. Đăc điểm BVMĐTĐ ( $n=87)$

\begin{tabular}{|c|c|c|}
\hline BVMĐTÐ & $\mathbf{n}$ & $\mathbf{\%}$ \\
\hline Không có tốn thương & 55 & $63,2 \%$ \\
\hline Có tốn thương & 32 & 36,8 \\
\hline
\end{tabular}

Nhận xét: Tỉ lệ bệnh nhân có tổn thương võng mạc mắt là $36,8 \%$ trong khi bệnh nhân không có tổn thương chiếm 63,2%.

2. Nồng độ $C-$ Peptide và mối liên quan đến biến chứng vi mạch

2.1. Nồng độ $C$ - Peptide lúc đói của nhóm nghiên cứu

Bảng 5. Nồng độ C-Peptide lúc đói của nhóm nghiên cứu $(n=87)$

\begin{tabular}{|c|c|}
\hline & Giá trị \\
\hline $\bar{x}_{ \pm}$C - Peptide (nmol/L) & $0,83 \pm 0,35$ \\
& $(0,21 \div 1,81)$ \\
\hline
\end{tabular}

Nhận xét: Nồng độ $\mathrm{C}$ - Peptide lúc đói trung bình của nhóm đối tượng nghiên cứu là $0,83 \pm$ 0,35 , với nồng độ $C$ - Peptide thấp nhất là 0,21 , cao nhất là 1,81.

2.2. Môí tương quan giữa nồng độ $C$ Peptide với MAU

Bảng 6. Mối tương quan giữa nồng độ $C$ - Peptide với MAU (n =87)

\begin{tabular}{|c|c|c|c|}
\hline \multirow[b]{2}{*}{ Đặc điểm } & \multicolumn{2}{|c|}{ Microalbumin niệu } & \multirow[b]{2}{*}{$\mathbf{p}$} \\
\hline & $\begin{array}{c}\text { Không } \\
(n=60)\end{array}$ & $\begin{array}{c}\text { Có } \\
(n=27)\end{array}$ & \\
\hline $\begin{array}{c}\text { C - Peptide } \\
\text { (nmol/L) } \\
\bar{X}_{ \pm} \text {SD }\end{array}$ & $\begin{array}{c}0,88 \pm \\
0,35\end{array}$ & $\begin{array}{c}0,72 \pm \\
0,34\end{array}$ & 0,047 \\
\hline
\end{tabular}

Nhận xét: Trong nhóm đối tượng nghiên cứu, nhóm có Microalbumin niệu có nồng độ $\mathrm{C}$ Peptide $(0,72 \pm 0,34)$ thấp hớn nhóm không có Microalbumin niệu $(0,88 \pm 0,35)$. Sự khác biệt có ý nghĩa thống kể với $p<0,05(\mathrm{p}=0,047)$ (Mann - Whitney U Test). Nồng độ $C$ - Peptide có mối tương quan nghịch biến mức độ vừa phải với nồng độ albumin niệu (Spearman Test, $r=$ $0,352, \mathrm{p}=0,001)$.

2.3. Môi tương quan giữa nồng độ C Peptide với BVMĐTÐ

Bảng 7. Môi tương quan giữa nồng độ $C$ - Peptide với BVMĐTÐ

\begin{tabular}{|c|c|c|c|}
\hline \multirow{2}{*}{ Đặc điểm } & \multicolumn{2}{|c|}{ BVMĐTÐ } & \multirow{2}{*}{ p } \\
\cline { 2 - 3 } & Không & Có & \\
\hline C- Peptide & $0,9 \pm$ & $0,72 \pm$ & 0,041 \\
$(\mathrm{nmol} / \mathrm{L})^{X_{ \pm}}$SD & 0,36 & 0,33 & 0,041 \\
\hline
\end{tabular}

Nhân xét: Trong nhóm đối tượng nghiên cứu, nhóm có BVMĐTÐ có nồng độ $C$ - Peptide $(0,72 \pm 0,33)$ thấp hơn nhóm không có BVMĐTĐ $(0,9 \pm 0,36)$. Sự khác biệt có ý nghĩa thống kê với $p<0,05(p=0,041)$ (Mann - Whitney U Test).

\section{BÀN LUẬN}

4.1. Đặc điểm chung của đối tượng nghiên cứu. Trong nghiên cứu của chúng tôi, tuổi của nhóm đối tượng là từ 31 đến 81 tuổi, trong đó nhóm có độ tuổi từ 40 - 60 chiếm $66,7 \%$. Đây là nhóm đối tượng có độ tuổi lao động -lực lượng đáng kể, đóng góp nhiều cho xã hội. Tỷ lệ bệnh cao nhất ở nhóm này cho thấy ĐTÐ là một gánh nặng cho gia đình và xã hội. Tì lệ nam, nữ mắc bệnh ĐTĐ type 2 trong nghiên cứu là xấp xỉ nhau. Nhóm thừa cân béo phì chiếm tỉ lệ cao nhất $(65,5 \%)$. Tỉ lệ bệnh nhân có Microalbumin niệu là $31 \%$, nhóm còn lại không có Microalbumin niệu chiếm $69 \%$. Kết quả này của chúng tôi cũng khá tương đồng với kết quả của Tauseef Ahmad và cộng sự. ${ }^{2}$ Chúng tôi cũng đánh giá tỉ lệ các bệnh nhân có bệnh võng mạc đái tháo đường (BVMĐTĐ): 36,8\%, nhóm bệnh nhân không có tổn thương chiếm $63,2 \%$. Kết quả này của chúng tôi cũng khá tương đồng với nghiên cứu của Joanne W Y Yau và cộng sự ${ }^{3}$. Có thể thấy BVMĐTĐ đang là một thách thức với các nhà chuyên môn, nếu không được kiểm soát thường xuyên, nó sẽ trở thành một yếu tố chính gây mất thị lực ở người trưởng thành.

4.2. Nồng độ $C$ - Peptide và mối liên quan đến biến chứng vi mạch. Trong nhóm nghiên cứu của chúng tôi, nồng độ $C$ - Peptide lúc đói trung bình của bệnh nhân là $0,83 \pm 0,35$ $\mathrm{nmol} / \mathrm{l}$, với nồng độ thấp nhất là $0,21 \mathrm{nmol} / \mathrm{l}$ và cao nhất là $1,81 \mathrm{nmol} / \mathrm{l}$. Kết quả này của chúng 
tôi cũng khá tương đồng với M.N.Chowta và cộng sự. ${ }^{4}$ Trong nghiên cứu của chúng tôi, nồng độ $\mathrm{C}$ - Peptide lúc đói ở nhóm bệnh nhân có MAU và không có MAU lần lượt là: $0,72 \pm 0,34$ $\mathrm{nmol} / \mathrm{l}$ và $0,88 \pm 0,35 \mathrm{nmol} / \mathrm{l}$. Sự khác biệt có ý nghĩa thống kê với $p<0,05$ ( $p=0,047$, Mann Whitney U Test). Ngoài ra chúng tôi cũng nhận thấy có sự tương quan nghịch biến mức độ vừa phải giữa nồng độ $C$ - Peptide lúc đói với nồng độ albumin niệu (Spearman Test, $r=-0,352, p=$ $0,001)$. Kết quả này cũng tương tự với nghiên cứu của Maimoona Mushtaq Masoom và công sự ${ }^{5}$ cũng như'S. Bo và cộng sự. . Cơ chế về $C-$ Peptide tác động đến chức năng thận vẫn còn chưa được làm rõ. Tuy nhiên có thể C - Peptide có ảnh hưởng đến việc giảm albumin niệu, dựa trên nghiên cứu của Mats Sjoquist và cộng sự thí nghiệm trên chuột. ${ }^{7}$ Cũng trong nghiên cứu của chúng tôi, nồng độ $C$ - Peptide lúc đói trên nhóm bệnh nhân có $B V M Đ T Đ$ và không có $B V M Đ T Đ$ lần Iượt là: $0,72 \pm 0,33 \mathrm{nmol} / \mathrm{lvà} 0,9 \pm 0,36 \mathrm{nmol} / \mathrm{l}$. Sự khác biệt này có ý nghĩa thống kê với $\mathrm{p}<$ 0,05 ( $p=0,041$, Mann - Whitney U Test). Điều này phù hợp với nhận xét của S.Bo và cộng sự̆.

\section{KẾT LUÂN}

- Nồng độ $C$ - Peptide lúc đói trên nhóm bệnh nhân nghiên cứu là $0,83 \pm 0,35 \mathrm{nmol} / \mathrm{l}$.

- Có mối tương quan nghịch biến mức độ vừa phải giữa nồng độ $\mathrm{C}-$ Peptide lúc đói với nồng độ Albumin niệu. Nhóm bệnh nhân có MAU có nồng độ $\mathrm{C}$ - Peptide thấp hơn so với nhóm bệnh nhân không có MAU. Sự khác biệt có ý nghĩa thống kê.

- Nồng độ $C$ - Peptide lúc đói giảm liên quan có ý nghĩa tới BVMĐTĐ.

\section{TÀI LIÊU THAM KHẢO}

1. Gross JL, de Azevedo MJ, Silveiro SP, Canani LH, Caramori ML, Zelmanovitz T. Diabetic nephropathy: diagnosis, prevention, and treatment. Diabetes Care. 2005;28(1):164-176. doi:10.2337/diacare.28.1.164

2. Ahmad $T$, Ulhaq $I$, Mawani $M$, Islam $N$. Microalbuminuria in Type-2 Diabetes Mellitus; the tip of iceberg of diabetic complications. Pak J Med Sci. 2017;33(3):519-523. doi:10.12669/ pjms.333.12537

3. Yau JWY, Rogers SL, Kawasaki R, et al. Global prevalence and major risk factors of diabetic retinopathy. Diabetes Care. 2012;35(3):556-564. doi:10.2337/dc11-1909

4. Chowta MN, Adhikari PM, Chowta NK Shenoy AK, D'Souza S. Serum C peptide level and renal function in diabetes mellitus. Indian J Nephrol. 2010;20(1):25-28. doi:10.4103/09714065.62093

5. Masoom MM, Albiladi F. C-Peptide as a Marker for Diabetic Nephropathy. Intern Med Open Access. 2017; 07(03). doi:10.4172/2165-8048. 1000245

6. Bo $S$, Cavallo-Perin $P$, Gentile $L$, Repetti $E$, Pagano G. Relationship of residual beta-cell function, metabolic control and chronic complications in type 2 diabetes mellitus. Acta Diabetol. 2000;37(3):125-129. doi:10.1007/s005920070014

7. Sjöquist $M$, Huang $\mathbf{W}$, Johansson BL. Effects of C-peptide on renal function at the early stage of experimental diabetes. Kidney Int. 1998; 54(3): 758-764. doi:10.1046/j.1523-1755.1998.00074.x

\section{SO SÁNH CÁC PHƯƠNG PHÁP KIỂM TRA DELTA CHO MộT SỐ XÉT NGHIÊM HÓA SINH}

\section{TÓM TĂT}

Kiểm tra delta (Delta check) là phương pháp kiểm soát chất lượng so sánh kết quả xét nghiệm hiện tai và kết quả trước đây của cùng môt bệnh nhân phát hiện xem sự khác biệt giữa hai kết quả có vượt quá các tiêu chí được xác đinh trước hay không. Kiểm tra delta đảm bảo phát hiện các lỗi giai đoan trước xét nghiệm, lỗi sao chép và lỗi ngẫu nhiên khống thể phát

${ }^{1}$ Trường Đại học Y Hà Nội

${ }^{2}$ Bênh viên Thanh Nhàn Hà Nôi

Chịu trách nhiệm chính: Nguyễn Thị Tùy Châu

Email: anhchau2016hs@gmail.com

Ngày nhận bài: 22.6.2021

Ngày phản biên khoa hoc: 16.8.2021

Ngày duyệt bài: 24.8.2021

\section{Trần Thị Chi Mai ${ }^{1}$, Nguyễn Thị Tùy Châu $^{2}$}

hiên được bằng các phương pháp kiểm soát chất lượng thường được sử dụng, do đó cải thiện độ tin cậy của các xét nghiệm. Nghiên cứu được tiến hành nhằm so sánh phân bố số liệu của khác biệt delta và thay đổi phần trăm delta chó một số xét nghiếm hoá sinh trên bệnh nhân nội trú và ngoại trú. Thu thập các căp kết quả xét nghiệm của bệnh nhân được tiến hành trên cùng một máy hóa sinh tự động. Phân bố khác biệt delta ở các mức phân vị trền bềnh nhân nội trú của xét nghiệm Glucose, AST, ALT, Natri, Kali, Clo, Canxi lớn hơn so với trên bệnh nhân ngoại trú. Với xét nghiệm Urê và Creatinin, phân bố khác biệt delta trên bệnh nhân nội và ngoại trú có xu hướng tương tự nhau. Khi so sánh với bênh nhân nôi trú, phân vị thứ $50,95,97.5$ và 99 của thay đổi phần trăm delta của các xét nghiêm urê, creatinin, glucose, canxi trên bệnh nhân ngoại trú nhỏ hơn; trong khi AST, ALT, 
Natri, Kali, Clo lại có xu hướng ngược lại. Kết quả này cho thấy việc phân chia bệnh nhân thành nhóm nội trú và ngoại trú là thích hợp để xác định các ngưỡng kiểm tra delta phù hợp cho mối đối tượng này.

Tư khóa: Kiểm tra delta, khác biệt delta, thay đổi phần trăm delta, bệnh nhân nội trú, bệnh nhân ngoại trú.

\section{SUMMARY \\ DELTA CHECKS COMPARED FOR SELECTED BIOCHEMISTRY TESTS}

Delta check is a quality control method that compares current and previous test results of patients and detects whether the difference between the two results exceeds pre-defined criteria. Delta check methods ensure the detection of pre-analytical errors, clerial errors, and random errors that cannot be detected using commonly used quality control methods, thereby improving the reliability of clinical tests. The study was conducted to compare the distribution of delta difference and delta percent change for several biochemical tests in inpatients and outpatients. The paired of patient test results obtained on the same automated biochemistry analyser for 9 clinical chemistry tests were collected from inpatients and outpatients. The distribution of delta difference of glucose, AST, ALT, sodium, potassium, chloride, calcium tests at several percentiles in inpatients was larger than in outpatients. For urea and creatinine tests, the distribution of delta differences in inpatients and outpatients tended to be similar. When compared with inpatients, the 50th, 95th, 97.5th, and 99th percentiles of the delta percent change of the urea, creatinine, glucose, calcium tests in the outpatients were smaller; while AST, ALT, sodium,potassium, chloride tended to be larger. This result suggests that it is needed to divide patients into inpatient and outpatient groups to determine appropriate delta check thresholds for each of these subjects.

Keywords: Delta check, delta difference, delta percent change, inpatient, outpatient.

\section{I. ĐĂT VẤN ĐỀ}

Theo dõi sư thay đổi trên lâm sàng ở bênh nhân là một lý do phổ biến để chỉ định các xét nghiệm. Những thay đổi trong kết quả xét nghiểm ở các mẫu liên tiếp trên cùng bênh nhân có thể xảy ra do nhiều yếu tố khác nhau: giai đoạn trước xét nghiệm, xét nghiệm, sau xét nghiệm, biến thiên sinh học, các yếu tố sinh lý bệnh và sai số. Bên cạnh kiểm tra chất lượng xét nghiệm, nhu cầu về các quy trình đảm bảo chất lượng khác phát sinh do sai sót xảy ra nhiều nhất ở giai đoạn trước xét nghiệm[1], gần $50 \%$ trong số này có liên quan đến thu thập mẫu và lỗi ghi nhãn [2]. Kiểm tra Delta (Delta check) là phương pháp kiểm soát chất lượng so sánh kết quả xét nghiệm hiện tại và kết quả trước đây của cùng một bênh nhân phát hiện xem sự khác biệt giữa hai kểt quả có vượt quá các tiêu chí được xác định trước hay không. Nếu chênh lệch nhỏ hơn tiêu chí được xác định trước, kết quả sẽ được báo cáo tự động; tuy nhiên nếu sự khác biệt vượt quá các tiêu chí được xác định trước, kết quả chỉ được trả sau khi nhân viên phòng xét nghiệm xem xét và xác nhận thủ công[3],[4]. Kiểm tra Delta đảm bảo phát hiện các lối giai đoạn trước xét nghiệm, lỗi sao chép và lỗi ngẫu nhiên không thể phát hiện được bằng các phương pháp kiểm soát chất lượng thường được sử dung, do đó cải thiện độ tin cậy của các xét nghiệm lâm sàng [5],[6]. Tuy nhiên việc sử dụng quá mức hoặc không phù hợp các phương pháp kiểm tra delta có thể làm chậm thời gian trả kết quả và tăng khối lượng công việc do cần phải xác nhận thêm các kết quả xét nghiệm bằng phương pháp thủcông. Do đó việc sử dụng các phương pháp kiểm tra delta thích hợp nhất trong phòng xét nghiệm có thể giảm thiểu khối lượng công việc và cải thiện tốc độ phát hiện lỗi [5],[6]. Hầu hết các phòng xét nghiệm đều dựa trên môt trong 4 phương pháp kiểm tra delta là: khác biêtt delta (delta difference), thay đổi phần trăm delta (delta percent change), khác biệt tỷ lệ (rate difference) và thay đổi phần trăm tỳ lể (rate percent change) cho mỗi xét nghiệm [7]. Môt thách thức lớn trong lựa chọn phương pháp kiểm tra delta là không có các tiêu chuẩn lựa chọn cụ thể được xác lập. Hơn nữa các đặc điểm lâm sàng của bểnh nhân có thể cần phải xem xét khi lựa chọn phương pháp kiểm tra delta thích hợp. Một số tình trạng bệnh nặng của bệnh nhân nổi trú sẽ có thể gây ra những thay đổi lớn về kết quả xét nghiệm, trong khi đó các bênh nhân ngoại trú thường có tình trạng ổn định hơon.

Theo hiểu biết của chúng tôi, ở Viêt Nam chưa có nhiều báo cáo về các phương pháp kiểm tra delta áp dụng trong phòng xét nghiệm. Để tìm hiểu về các phương pháp kiểm tra delta, lựa chọn phương pháp thích hợp cho từng xét nghiệm, đề tài này được thực hiện với mục tiêu: So sánh phân bố số liệu của khác biệt delta (delta difference) và thay đổi phần trăm delta (delta percent change) cho môt số xét nghiêm hoá sinh trên bệnh nhân nội trú và ngoại trú.

\section{II. ĐỐI TƯợNG VÀ PHƯƠNG PHÁP NGHIÊN CỨU}

1. Đối tượng nghiên cứu. Lựa chọn một số các xét nghiệm hoá sinh thường được chỉ định để theo dõi bệnh nhân: Natri, Kali, Clo, Canxi, Glucose, Urê, Creatinin, AST, ALT.

Thu thập kết quả các xét nghiệm trên trong vòng 6 tháng: các cặp kết quả trền cùng bệnh nhân, bệnh nhân ngoại trú và nội trú.

Các xét nghiệm được thực hiện trên bệnh nhân tại Bệnh viện đa khoa Thanh Nhàn, Hà Nội 
từ tháng 08/2020 đến tháng 02/2021

Đối tượng bệnh nhân: Bệnh nhân nội trú và ngoại trú, cả nam và nữ, độ tuổi chọn bệnh nhân từ trên 18 tuổi.

\section{Phương pháp}

-Thiết kế nghiên cứu trước sau, chọn mẫu có chủ đích, cõ̃ mầu thuận tiện

- Đặc điểm của đối tượng nghiên cứu như: tuổi, giới, kết quả xét nghiệm

- Tính toán và mô tả phân bố của kiểm tra delta bằng phần mền Excel:

+ Khác biệt delta $=$ Delta Difference (DD)= (Kết quả xét nghiệm hiện tại- Kết quả xét nghiệm trước đó)

+ Thay đổi phần trăm delta= Delta percent change (DPC) = (kết quả cao- kết quả thấp) /kết quả thấp x $100 \%$

3. Đạo đức nghiên cứu. Nghiên cứu chỉ thu thập số liệu sắn có của Phòng xét nghiệm không ảnh hưởng đến bệnh nhân (không lấy mẫu, không làm thêm xét nghiệm, không can thiệp...). Giữ bí mật về thông tin cá nhân của bệnh nhân tham gia nghiên cứu.

\section{KẾT QUẢ NGHIÊN CứU}

Nghiên cứu đã thu thập số liệu trên 555 bệnh nhân nội trú và 455 ngoại trú, trong đó có 512 bệnh nhân nam, 498 bệnh nhân nữ. Nam nhỏ nhất là 18 tuôi, lớn nhất là 99 tuổi, nữ nhỏ nhất 18 tuổi và lớn nhất 97 tuổi.

Bảng 1. Khác biệt delta trên bệnh nhân nội trú

\begin{tabular}{|c|c|c|c|c|c|c|c|c|}
\hline \multirow{2}{*}{$\begin{array}{l}\text { Xét nghiệm } \\
\text { (đđơn vị đio) }\end{array}$} & \multicolumn{7}{|c|}{ Khác biệt delta (DD) *Phân vị } & \multirow{2}{*}{$\begin{array}{l}\text { Số cặp } \\
\text { kết quả }\end{array}$} \\
\hline & 1 & 2.5 & 5 & 50 & 95 & 97.5 & 99 & \\
\hline Ürê (mmol/L) & -21.43 & -13.5 & -9.14 & -0.10 & 10.64 & 15.7 & 20.35 & 1215 \\
\hline Creatinin $(\mu \mathrm{mol} / \mathrm{L})$ & -25 & -159.6 & -84.3 & $-4 . \varepsilon$ & 67.97 & 101.48 & 154.76 & 904 \\
\hline Glucose $(\mathrm{mmol} / \mathrm{L})$ & -17.05 & -9.53 & -7.3 & -0.4 & 5.17 & 7.56 & 8.19 & 208 \\
\hline AST(U/L) & & -442.8 & -267.56 & -4.95 & 67.86 & 136.36 & 258.8 & 845 \\
\hline & & -4 & -195.1 & -2 & 79.85 & & 300.23 & \\
\hline Natri $(\mathrm{m}$ & -14.59 & -10.0 & -7.00 & 1.00 & 8.00 & 10.00 & 15.59 & 1441 \\
\hline Kali(mmol/L) & -2.35 & -1.60 & -1.30 & 0.00 & 1.20 & 1.50 & 1.85 & 1141 \\
\hline Clo (mmol/L) & -14.5 & -12.0 & -9.0 & 0.00 & 9.00 & 12.00 & 14.57 & 1141 \\
\hline Canxi (mmol/L) & -0.59 & -0.58 & -0.51 & 0.00 & 0.27 & 0.35 & 0.42 & 53 \\
\hline
\end{tabular}

*Khác biệt delta $=$ Delta Difference $(\mathrm{DD})=$ quả xét nghiệm hiện tại thấp hơn trước đó, có (Kết quả xét nghiệm hiện tại- Kết quả xét bệnh nhân kết quả xét nghiệm hiện tại cao hơn nghiệm trước đó) (đơn vị của DD chính là đơn vị trước đó. Các xét nghiệm điện giải đồ, urê có đo lường)

Nhận xét: Ở bệnh nhân nội trú, tất cả các xét nghiệm đều có DD ở cả hai phía của 0 (cả giá trị âm và dương), tức là có bệnh nhân có kết phân phối đối xứng. Các xét nghiệm Creatinin Glucose, AST, ALT, Canxi phối không đối xứng và có xu hướng lệch âm (tức là kết quả hiện tại có xu hướng thấp hơn kết quả xét nghiệm trước đó).

Bảng 2. Kêt quả khác biệt delta trên bệnh nhân ngoại trú

\begin{tabular}{|c|c|c|c|c|c|c|c|c|}
\hline \multirow{2}{*}{$\begin{array}{l}\text { Xét nghiệm } \\
\text { (đơn vị đo) }\end{array}$} & \multicolumn{7}{|c|}{ Khác biệt delta (DD)* Phân vị } & \multirow{2}{*}{$\begin{array}{l}\text { Số căp } \\
\text { kết quả }\end{array}$} \\
\hline & 1 & 2.5 & 5 & 50 & 95 & 97.5 & 99 & \\
\hline Urê $(\mathrm{mmol} / \mathrm{L})$ & -28.40 & -24.62 & -12.27 & 1.00 & 11.50 & 12.68 & 23.0 & 190 \\
\hline Creatinin $(\mu \mathrm{mol} / \mathrm{L})$ & -210.24 & -43.97 & -29.77 & 0.15 & 193.87 & 242.84 & 314.59 & 462 \\
\hline Glucose $(\mathrm{mmol} / \mathrm{L})$ & -6.12 & -4.10 & -1.91 & 0.89 & 2.30 & 3.52 & 7.76 & 1077 \\
\hline & -56 & -30.08 & -18.91 & -0.20 & 18.40 & 32.75 & 128.12 & 896 \\
\hline $\mathrm{AL}$ & -76.85 & -43.94 & -23.10 & -1.10 & 19.73 & 28.66 & 62.84 & 896 \\
\hline Natri $(1$ & -24.00 & -9.00 & -5.00 & -1.00 & 6.00 & 7.00 & 9.80 & 158 \\
\hline Kali (mmol/L) & -0.74 & -0.70 & -0.50 & 0.10 & 0.80 & 0.90 & 1.24 & 158 \\
\hline Clo ( & -13.00 & -10.05 & -5.00 & 0.00 & 5.05 & 7.00 & 9.23 & 158 \\
\hline Canxi $(\mathrm{mmol} / \mathrm{L})$ & -0.34 & -0.28 & -0.19 & -0.01 & 0.20 & 0.30 & 0.35 & 128 \\
\hline
\end{tabular}

*Khác biệt delta $=$ Delta Difference $(\mathrm{DD})=$ (Kết quả xét nghiệm hiện tại- Kết quả xét nghiệm trước đó) (đớn vị của DD chính là đơn vị đo lường)

Nhận xét: Ở bệnh nhân ngoại trú, tất cả các xét nghiệm đều có $D D$ ở cả hai phía của 0 (cả giá trị âm và dương), tức là có bệnh nhân có kết quả xét nghiệm hiện tại thấp hơn trước đó, có bệnh nhân kết quả xét nghiệm hiện tại cao hơn trước đó. Trong số các xét nghiệm thì canxi phân phối đối xứng, các xét nghiệm còn lại phân phối không đối xứng. 
Bảng 3. Kêt quả thay đổi phàn trăm delta trên bệnh nhân nội trú

\begin{tabular}{|c|c|c|c|c|c|c|c|}
\hline \multirow{2}{*}{$\begin{array}{l}\text { Xét nghiệm } \\
\text { (đđơn vị đơ) }\end{array}$} & \multicolumn{7}{|c|}{ Thay đổi phân trăm delta (\%) *Phân vị } \\
\hline & 1 & 2.5 & 5 & 50 & 95 & 97.5 & 99 \\
\hline Urê (mmol/L) & 0.00 & 0.84 & 2.24 & 32.14 & 195.66 & 276.69 & 432.82 \\
\hline Creatinin $(\mu \mathrm{mol} / \mathrm{L})$ & 0.13 & 0.55 & 1.23 & 14.68 & 92.46 & 138.4 & 212.99 \\
\hline Glucose $(\mathrm{mmol} / \mathrm{L})$ & 0.00 & 1.26 & 1.75 & 6.43 & 135.7 & 228.5 & 316.7 \\
\hline AST(U/L) & 0.55 & 1.55 & 3.37 & 31.37 & 78.77 & 87.31 & 92.42 \\
\hline & 0.78 & 1.70 & 3.12 & 30.50 & 74.64 & 85.96 & 91.72 \\
\hline Natri(m & 0.00 & 0.00 & 0.00 & 1.96 & 7.80 & 10.29 & 16.10 \\
\hline Kali (mmol/L) & 0.00 & 0.00 & 0.00 & 11.76 & 51.72 & 62.96 & 87.5 \\
\hline Chlorid(mmol/L) & 0.00 & 0.00 & 0.00 & 2.97 & 12.64 & 15.64 & 18.94 \\
\hline Canxi (mmol/L) & 0.00 & 0.00 & 0.00 & 2.49 & 11.72 & 18.1 & 21.76 \\
\hline
\end{tabular}

*Thay đối phần trăm delta $=$ Delta percent change $=$ (kết quả cao- kết quả thấp) /kết quả thấp x100\% (đơn vị đo là \%).

Nhận xét: Phần lớn các xét nghiệm có phân vị thứ 1 là $0 \%$ (6/9 xét nghiệm) và xấp xỉ với $0 \%$. Điều này phù hợp với trung vị các kết quả xét nghiệm hiện tại xấp xỉ với trung vị kết quả xét nghiệm trước đó, do vậy thay đổi phần trăm delta xấp xỉ với 0 . Phân vị thứ 95 của của các xét nghiệm Natri, Clo, Canxi $<20 \%$, các xét nghiệm Kali, $\mathrm{AST}$, $\mathrm{ALT}$, Urê $>50 \%$, các xét nghiệm creatinine và̀ glucose đều $>100 \%$.

Bảng 4. Kêt quả thay đổi phần trăm delta trên bệnh nhân ngoại trú

\begin{tabular}{|c|c|c|c|c|c|c|c|}
\hline \multirow{2}{*}{$\begin{array}{c}\text { Xét nghiệm } \\
\text { (đơn vị đo) }\end{array}$} & \multicolumn{7}{|c|}{ Thay đối phần trăm delta (\%) *Phân vị } \\
\hline & 1 & 2.5 & 5 & 50 & 95 & 97.5 & 99 \\
\hline Urê $(\mathrm{mmol} / \mathrm{L})$ & 1.0 & 1.19 & 2.10 & 21.70 & 98.18 & 222.94 & 522 \\
\hline Creatinin(mmol/L) & 0.18 & 0.37 & 0.76 & 7.34 & 35.33 & 44.19 & 57.21 \\
\hline Glucose(mmol/L) & 0.00 & 1.71 & 4.53 & 11.68 & 54.22 & 89.60 & 127.57 \\
\hline AST(U/L) & 0.36 & 0.80 & 1.61 & 16.98 & 103.50 & 132.54 & 217.64 \\
\hline ALT(UL) & 0.62 & 1.36 & 2.27 & 24.77 & 127.49 & 185.28 & 266.46 \\
\hline Natri(mmol/L) & 0.00 & 0.00 & 0.00 & 1.45 & 5.55 & 11.47 & 23.69 \\
\hline Kali $(\mathrm{mmol} / \mathrm{L})$ & 0.00 & 0.00 & 0.00 & 5.88 & 21.14 & 24.30 & 34.78 \\
\hline Chlorid(mmol/L) & 0.00 & 0.00 & 0.00 & 1.98 & 8.65 & 12.40 & 14.94 \\
\hline Calcium(mmol/L) & 0.00 & 0.41 & 0.42 & 2.59 & 13.36 & 15.80 & 18.62 \\
\hline
\end{tabular}

*Thay đổi phần trăm delta $=$ Delta percent change $=$ (kết quả cao- kết quả thấp)/kết quả thấp $\mathrm{x} 100 \%$

Nhận xét: Ngoại trừ xét nghiệm urê phân vị 1 là $1.0(\%)$ còn các xét nghiệm khác đều nhỏ hơn 1 và xấp xỉ $0(\%)$. Điêu này phù hợp với trung vị các kết quả xét nghiệm hiện tại xấp xỉ với trung vị kết quả xét nghiệm trước đó, do vậy thay đổi phần trăm delta xấp xỉ với 0 . Phân vị thứ 95 của của các xét nghiệm Natri, Clo, Canxi $<20 \%$, các xét nghiệm Kali, creatinin < $50 \%$, Glucose, ure $>50 \%$, các xét nghiệm AST, ALT > 100\%.

\section{BÀN LUÂ̂N}

Các phương pháp kiểm tra delta đảm bảo phát hiện các sai sót trước xét nghiệm, sai số ngẫu nhiên không thể phát hiện được bằng các phương pháp kiểm tra chất lượng xét nghiệm thường dùng, do vậy làm cải thiện độ tin cậy của kết quả xét nghiệm. Trong nghiên cứu này, chúng tôi mô tả phân phối của cả 2 phương pháp kiểm tra delta thường được sử dụng: khác biệt delta (delta difference), thay đổi phần trăm delta (delta percent change). Các xét nghiệm

nghiên cứu bao gồm: urê, creatinin, glucose, ASI, ALT, điện giải đồ (natri, kali, clo) và canxi. Trong nghiên cứu này, phân bố kiểm tra delta theo cả 2 phương pháp được mô tả và được phân chia theo 2 nhóm bệnh nhân nội trú và ngoại trú. Các bệnh nhân nội trú, đặc biệt bệnh nhân nặng và có can thiệp điều trị tích cực, thường có sự thay đổi kết quả xét nghiệm nhiều hơn; do vậy việc sử dụng các ngưỡng cảnh báo delta khác với bệnh nhân ngoại trú (thường trong tình trạng ổn định hơn) là điều hợp lý [7],[8]. Phân bố khác biệt delta (DD) ở các phân vị $1,2.5,5,95,97.5$ và 99 trên bệnh nhân nội trú của xét nghiệm AST, ALT là lớn hơn rất nhiều so với khác biệt delta này trên bệnh nhân ngoại trú (bảng 1 và bảng 2). Điều này cho thấy khi tế bào gan bị tổn thương hay hủy hoại do nhiều nguyên nhân khác nhau thì thường là lý do khiến bệnh nhân phải nhập viện điều trị nội trú. Với các xét nghiệm kali và canxi, khác biệt delta ở 
các phân vị 1 1, 2.5 , 5, 95, 97.5 và 99 trên bênh nhân nội trú cũng có xu hướng lớn hơn bệnh nhân ngoại trú. Điều này cũng dế lý giải bởi đây là các ion mà sự hằng định nội môi của chúng vô cùng quan trọng với sự sống của cơ thể, do vậy các bệnh nhân ngoại trú sự biến động của các ion này sẽ ít hơn. Với xét nghiệm urê và creatinin, phân bố khác biệt delta trên bệnh nhân nôi và ngoai trú có xu hướng tương tư nhau (bảng 1 và 2), điều này có thể giải thích bằng có nhóm bệnh nhân thận mạn chạy thận nhân tao sẽ không nằm điều trị nội trú. Ớ bênh nhân nội trú và ngoaii trú, tất cả các xét nghiệm đều có khác biệt delta (DD) ở cả hai phía của 0 (cả giá trị âm và dương), tức là có bệnh nhân có kết quả xét nghiệm hiện tại thấp hơn trước đó, có bệnh nhân kểt quả xét nghiệm hiên tại cao hơn trước đó. Với bệnh nhân nội trú, các xét nghiệm điện giải đồ, urê có phân phối đối xứng. Các xét nghiệm Creatinin, Glucose, AST, ALT, Canxi phối khồng đối xứng và có xu hướng lệch âm (tức là kết quả hiện tại có xu hướng thấp hơn kết quả xét nghiệm trước đó). Với bệnh nhân ngoại trú, trong số các xét nghiệm thì canxi phân phối đối xứng, các xét nghiệm còn lại phân phối không đối xứng. Từ phân bố kết quả khác biệt delta của 9 xét nghiệm cho thây việc sử dụng các ngưỡng cảnh báo delta theo phương pháp khác biêtt delta sẽ khác nhau cho một số xét nghiệm trên 2 đối tượng bệnh nhân nội trú và ngoại trú vì biến đổi sinh lý bệnh của 2 nhóm bênh nhân này không giống nhaú. Việc sử dụng chung ngưỡng cảnh báo có thể dẫn tới nhiều cảnh báo dương tính giả hoặc âm tính giả [8].

Một phương pháp tiếp cận nữa trong kiểm tra delta là tính thay đổi phần trăm delta (DPC). Trong nghiên cứu này công thức thay đổi phần trăm delta $=$ Delta percent change $=$ (kết quả cao- kết quả thấp) /kết quả thấp x $100 \%$ nên các kết quả thu được luôn mang giá trị dương. Với bệnh nhân nội trú, phân vị thứ 95 của của các xét nghiệm Natri, Clo, Canxi $<20 \%$, các xét nghiệm Kali, AST, ALT, ure > 50\%, các xét nghiệm creatinine và glucose đều $>100 \%$ (bảng 3). Với bệnh nhân ngoại trú, phân vị thứ 95 của của các xét nghiệm Natri, Clo, Canxi $<20 \%$, các xét nghiệm Kali, creatinin < $50 \%$, Glucose, ure > $50 \%$, các xét nghiêm AST, ALT > 100\% (bảng 4). Khi so sánh với bệnh nhân nội trú, phân vị thứ $50,95,97.5$ và 99 của thay đổi phần trăm delta của các xét nghiệm urê, creatinin, glucose, canxi trên bệnh nhân ngoại trú nhỏ hơn (bảng 3 và 4), trong khi AST, ALT, Natri, Kali, Clo lại có xu hướng ngược lại. Điều này có thể lý giải là các xét nghiệm đánh giá hủy hoại tế bào gan (ALT, AST) và điện giải đồ khi có sự thay đổi nhiều sẽ xuất hiện các triệu chứng lâm sàng bất thường, là lý do khiến bểnh nhân ngoại trú tái khám. Nếu như so sánh khác biệt delta (DD) ở của AST và ALT ở bệnh nhân nội trú lớn hơn ngoại trú (bảng 1 và 2) thì so sánh thay đổi phần trăm delta (DPC) của hai xét nghiêm này ở bênh nhân ngoại trú lại lớn hơn nội trú (bảng 3 và 4). Điều này cũng hoàn toàn có thể lý giải được là trên bệnh nhân nội trú khoảng thời gian giữa 2 lần xét nghiệm là ngắn hơn rất nhiêu, tình trạng bệnh nhân nội trú có tăng hoạt độ AST, ALT thường nặng, nên nếu xem xét mức nồng độ thì sẽ thấy tăng cao và sự biến thiên giữa hai lần xét nghiêm cũng chêch lêch lớn (tức là khác biệt delta lớn). Tuy nhiên, khi tính thay đổi phần trăm delta thì sự chênh lệch này được chuyển về phần trăm ((kết quả cao- kết quả thấp)x100\%/ kết quả thấp )) nên sự thay đổi của AST và ALT của bệnh nhân ngoại trú lại lớn hơn ở bệnh nhân nội trú (bảng 3 và 4). Kết quả này một lần nữa cho thấy việc phân chia bệnh nhân thành nhóm nội trú và ngoại trú là thích hợp để xác định các ngưỡng kiểm tra delta phù hợp cho mỗi đối tượng này. Việc sử dụng các phương pháp kiểm tra khác biệt delta hoặc thay đổi phần trăm delta phụ thuộc vào độ lớn của các giá trị xét nghiệm. Khác biệt Delta (DD) dựa trên sự khác biệt có xu hướng hữu ích ở phạm vi giá trị xét nghiệm thấp hơn hoặc xung quanh các giá trị quan trọng đối với các quyết định lâm sàng. Trái lại, các phương pháp thay đổi phần trăm delta (DPC) thường là hữu ích cho các giá trị xét nghiệm cao hơn [9].

\section{KẾT LUÂNN}

Phân bố khác biệt delta (DD) ở các mức phân vị trên bệnh nhân nội trú của xét nghiệm Glucose, AST, ALT, Natri, Kali, Clo, Canxi lớn hơn so với trên bệnh nhân ngoại trú. Với xét nghiệm urê và creatinin, phân bố khác biệt delta trên bệnh nhân nội và ngoại trú có xu hướng tương tự nhau. Khi so sánh với bệnh nhân nội trú, phân vị thứ $50,95,97.5$ và 99 của thay đổi phần trăm delta (DPC) của các xét nghiệm urê, creatinin, glucose, canxi trên bệnh nhẩn ngoại trú nhỏ hơn; trong khi AST, ALT', Natri, Kali, Clo lại có xu hướng ngược lại.

\section{TÀI LIẸU THAM KHẢO}

1. Bonini, P., et al., Errors in laboratory medicine. Clin Chem, 2002. 48(5): p. 691-8.

2. Snydman, L.K., et al., Voluntary electronic reporting of laboratory errors: an analysis of 37,532 laboratory event reports from 30 health care organizations. Am J Med Qual, 2012. 27(2): 
p. $147-53$.

3. Kazmierczak, S.C., Laboratory quality control: using patient data to assess analytical performance. Clin Chem Lab Med, 2003. 41(5): p. 617-27.

4. Straseski, J.A. and F.G. Strathmann, Patient data algorithms. Clin Lab Med, 2013. 33(1): p. 147-60.

5. Nosanchuk, J.S. and A.W. Gottmann, CUMS and delta checks. A systematic approach to quality control. Am J Clin Pathol, 1974. 62(5): p. 707-12.

6. Wheeler, L.A. and L.B. Sheiner, A clinical evaluation of various delta check methods. Clin Chem, 1981. 27(1): p. 5-9.
7. Park S, Kim S-Y, Lee W, Chun S, Min W-K. New Decision Criteria for Selecting Delta Check Methods Based on the Ratio of the Delta Difference to the Width of the Reference Range Can Be Generally Applicable for Each Clinical Chemistry Test Item Annals of laboratory medicine. 2012; 32:345-354.

8. Kim, J.W., J.Q. Kim, and S.I. Kim, Differential application of rate and delta check on selected clinical chemistry tests. J Korean Med Sci, 1990. 5(4): p. 189-95.

9. Lacher, D.A. and D.P. Connelly, Rate and delta checks compared for selected chemistry tests. Clin Chem, 1988. 34(10): p. 1966-70.

\title{
LÂM SÀNG, CÂN LÂM SÀNG BÊ̂NH NHÂN COVID-19 VÀ SốT RÉT TẠI BỆNH VIỆN BỆNH NHIỆT ĐỚI TRUNG ƯƠNG
}

\author{
Thân Mạnh Hùng1, Nguyễn Đức Minh', Lê Văn Nam²
}

\section{TÓM TẮT}

Mục tiêu: Mô tả đặc điểm lâm sàng, cận lâm sàng của bểnh nhân COVID-19 và bệnh nhân sốt rét trong vụ dịch COVID-19 năm 2020. Đối tượng và phương pháp: Mổ tả cắt ngang 71 bệnh nhân, trong đó 60 bệnh nhân COVID-19 và 11 bệnh nhân sốt rét điều trị tại Bệnh viện Bệnh Nhiệt đới trung ương, thu thập về các biểu hiện lâm sàng, cận lâm sàng và diễn biến của bệnh.Kết quả: Sốt hay gặp ở nhóm sốt rét $(90,1 \%)$, cao hơn nhóm COVID-19 (45\%). Ho gặp chủ yếu ở nhóm BN COVID-19 (75\%). Thời gian ủ bệnh trung bình của bệnh nhân COVID-19 là 6,53 \pm 4,07 ngày. Thời gian thanh thải virus: $8,22 \pm 4,83$ ngày. Thời gian sach KST sốt rét trong máu là 4,18 $\pm 2,09$ ngày. Nhóm sốt rét D-dimer tăng cao (IQR: $2829 \mathrm{ng} / \mathrm{ml}$ so với 733 $\mathrm{ng} / \mathrm{ml})$, với $\mathrm{p}=0,002$. PCT ở bệnh nhân sốt rét tăng cao hơn bênh nhân COVID-19 (IQR: $1,715 \mathrm{ng} / \mathrm{ml}$ so với $0,028 \mathrm{ng} / \mathrm{ml}$ ) với $\mathrm{p}=0,02$. 75\% bệnh nhân có tổn thương phối trên phim CT ngực, chủ yếu tổn thương 2 bên (80\%). Kết luận:Sốt là triệu chứng chung của sốt rét và COVID-19, không nên bỏ qua bệnh sốt rét trong các vụ dịch COVID-19 nếu bệnh nhân có yếu tố dịch tễ.

Tư khoá: SARS-CoV2, COVID-19, Sốt rét

\section{SUMMARY}

CLINICAL MANIFESTATION AND LABORATORY RESULTS AMONG COVID-19 AND MALARIA PATIENTS IN NATIONAL

HOSPITAL FOR TROPICAL DISEASES

Objectives: This study aims to describe the clinical manifestation and laboratory results among

\footnotetext{
${ }^{1}$ Bệnh viện Bệnh Nhiệt đới Trung ương

²Bệnh viện Quân Y 103

Chịu trách nhiệm chính: Thân Mạnh Hùng

Email: hungykhoa@gmail.com

Ngày nhận bài: 24.6.2021

Ngày phản biện khoa học: 18.8.2021

Ngày duyệt bài: 27.8.2021
}

COVID-19 and malaria patients in 2020.Participants and Methods: We conducted a cross-sectional study on 71 patients include 60 confirmation of SARS-CoV-2 using RT-PCR method and 11 malaria patients at National Hospital for Tropical Diseases. We collected information about clinical and subclinical characteristics by direct interview or extract from medical records. Results: The most common symptoms of malaria patients at admission were fever $(90.1 \%)$, in COVID-19 patients were $45 \%$, dry cough were common symptoms of COVID-19 patients (75\%) and The mean incubation period was 6.53 days. Duration of viral shedding was $8.22 \pm 4.83$ days. Clearance of parasitic malaria was $4.18 \pm 2.09$ days. D-Dimer in malaria patients increased (IQR: 2829 $\mathrm{ng} / \mathrm{mL}$ compared to $733 \mathrm{ng} / \mathrm{ml}$ ), with $\mathrm{p}=0.002$.PCT in malaria patients increased higher than COVID-19 patients (IQR: $1,715 \mathrm{ng} / \mathrm{mL}$ compared to $0.028 \mathrm{ng} / \mathrm{ml}$ ) with $\mathrm{p}=0.02$. On chest radiographs, we found lung damage in about $75 \%$ of patients. The bilateral lung damage was accounted $80 \%$, and mostly seen in the middle and the bottom of the lung. Conclusion: Fever is a common symptom of malaria and COVID19 , should not ignore malaria in COVID-19 pandemic if the patient has epidemiological elements.

Keywords; SARS-CoV-2, COVID-19, malaria

\section{I. ĐẶT VẤN ĐỀ}

Hội chứng suy hô hấp cấp do Coronavirus 2 (SARS-CoV2) lần đầu tiên được phát hiện vào cuối tháng 12/2019 tại tỉnh Vũ Hán - Trung Quốc. Tính đến ngày $06 / 06 / 2021$ trên toàn Thế giới ghi nhận tại 213 Quốc gia với 173,729,856 trường hợp nhiễm, tử vong 3,736,525 trường hợp chiếm tỷ lệ 2,15\%[1]. SARS-CoV2 là một coronavirus mới, lần đầu tiên được phát hiện gầy bệnh trên người. Bệnh lây từ người sang người qua giọt bắn đường hô hấp khi tiếp xúc gần. Bệnh gặp ở mọi lứa tuổi, với thời gian ủ bệnh trung bình 3 ngày với các triệu chứng chủ yếu là ho, sốt. Bệnh cảnh chủ yếu là viêm đường hô 
hấp, trong đó viêm phổi chiếm tỷ lệ 76,4\% [2]. Bệnh sốt rét nằm trong số mười nguyên nhân gâyy tử vong hàng đầu ở các nước thu nhập thấp và là một trong những thách thức lớn về sức khỏe toàn câu. Mặc dù 100 quốc gia trên toàn thế giới đã đạt được loại trừ dịch bệnh và hiện không còn bệnh sốt rét, nhưng vẫn có khoảng 300 triệu ca sốt rét và 500 nghìn trường hợp tử vong trên toàn thế giới trong năm 2018, trong đó châu Phi cận Sahara chịu gánh nặng lớn nhất [3]. Chúng tôi tiến nghiên cứunhằm mô tả đặc điểm lâm sàng, cận lâm sàng của bệnh nhẩn COVID-19 và Sốt rét với hy vọng trong quá trình điều trị các bác sĩ lâm sàng không chẩn đoán nhầm hay bỏ sót các bệnh trên.

\section{II. ĐỐI TƯợNG VÀ PHƯƠNG PHÁP NGHIÊN CỨU}

2.1. Đối tượng nghiên cứu: 71 bệnh nhân trong đó 60 bệnh nhân được chẩn đoán xác định nhiễm COVID-19 và 11 bệnh nhân chẩn đoán sốt rét điều trị tại Bệnh viện Bệnh Nhiệt đới Trung ương từ tháng 3 đến tháng 7/2020

2.2. Phương pháp: Mô tả cắt ngang, bệnh nhân được chuẩn đoán bằng dấu hiệu lâm sàng và RT-PCR xác định SARS-CoV2 cũng như nhuộm soi máu tìm KST sốt rét và test miễn dịch tìm kháng thể sốt rét trong máu. Chúng tôi tiến hành ghi lại các yếu tố dịch tễ, tiền sử, biểu hiện lâm sàng và các xét nghiệm huyết học, sinh hóa, Xquang phổi và CT ngực mỗi 3 ngày, kết quả RTPCR dịch ngoáy họng và dịch tỵ hâu, kết quả nhuộm soi tìm KST sốt rét trong máu. Các bệnh nhân được cách ly, lấy các mẫu xét nghiệm từ ngày đầu tiên nhập viện, và khi các biểu hiện lâm sàng thuyên giảm. Xét nghiệm RT-PCR xác định SARS-CoV2cũng như các xét nghiệm liên quan được làm tại khoa xét nghiệm đạt tiêu chuẩn ISO 15189 của Bệnh viện Bệnh Nhiệt đới Trung ương (đơn vị được Bộ Y tế cấp phép làm XN). Tất cả các kết quả xét nghiệm và diễn biến lâm sàng được khai thác và ghi lại trong mẫu hồ sơ nghiên cứu. Từ các khai thác về triệu chứng lâm sàng và xét nghiệm của bệnh nhân chúng tôi tìm hiểu thời gian tồn tại của các triệu chứng, thời gian thanh thải hoàn toàn virus SARS-CoV2 khỏi đường hô hấp trên (được tính là khoảng thời gian từ khi xuất hiện triệu chứng đầu tiên cho đến khi bệnh nhân làm xét nghiệm RT-PCR COVID-19 âm tính 2 lần liên tiếp) của bệnh nhân COVID-19. Thời gian hết KST sốt rét được tính từ khi tìm thấy KST đên khi hết KST trong quá trình điều trị.

2.3. Thu thập và xử lý số liệu: Thu thập số liệu bằng bệnh án nghiên cứu và xử lý sổ liệu bằng phần mềm SPSS và các thuật toán thống kê ứng dụng.

\section{KẾT QUẢ NGHIÊN CỨU}

\section{1. Đặc điểm nhóm nghiên cứu}

- Tuổi trung bình của nhóm nghiên cứu là 39,55 tuổi (trẻ nhất 17 tuổi, cao nhất 83 tuổi), nam nữ chiếm tỷ lệ tương đương 32/39 (tương ứng 45,1 và $54,9 \%$ ), chủ yếu là người Việt Nam $62 / 71$ (chiếm tỷ lệ $87,3 \%$, còn lại là quốc tịch Anh, Pháp, Đức, Mỹ)

- Bệnh nhân COVID-19: Thời gian ủ bệnh trung bình $6,53 \pm 4,07$ ngày. Thời gian nằm viện trung bình: 20,05 $\pm 11,38$ ngày. Kết quả điều trị 100\% bệnh nhân khỏi bệnh.

\subsection{Các biểu hiện lâm sàng}

Bảng 3.1. Đặc điểm lâm sàng nhóm nghiên cứlu

\begin{tabular}{|c|c|c|c|c|}
\hline \multicolumn{2}{|c|}{$\begin{array}{l}\text { Biếu hiện COVID- } \\
\text { lâm sàng 19(n,\%) }\end{array}$} & $\begin{array}{l}\text { Sốt rét } \\
(n, \%)\end{array}$ & $\begin{array}{l}\text { Tống } \\
(\mathrm{n}, \%)\end{array}$ & $\mathbf{p}^{*}$ \\
\hline \multicolumn{5}{|c|}{ Sốt } \\
\hline Có & $27(45)$ & $10(90,1)$ & $37(52,1)$ & \\
\hline Không & $33(55)$ & $1(9,9)$ & $34(47,9)$ & 0,005 \\
\hline \multicolumn{5}{|c|}{ Ho } \\
\hline Có & $45(75)$ & $3(27,3)$ & $48(67,6)$ & \\
\hline Không & $15(25)$ & $8(72,7)$ & $23(32,4)$ & \\
\hline \multicolumn{5}{|c|}{ Khó thở } \\
\hline Có & $3(5)$ & 0 & $3(4,2)$ & \\
\hline Không & $57(95)$ & $11(100)$ & $68(95,8)$ & 0,449 \\
\hline \multicolumn{5}{|c|}{ Đau đâu } \\
\hline Có & $7(11,7)$ & $4(36,4)$ & $11(15,5)$ & \\
\hline Không & $53(88,3)$ & $7(63,6)$ & $60(84,5)$ & 0,031 \\
\hline \multicolumn{5}{|c|}{ Đau mỏi cơ } \\
\hline Có & $4(6,7)$ & $2(18,2)$ & $6(8,5)$ & 0.21 \\
\hline Không & $56(93,3)$ & $9(81,8)$ & $65(91,5)$ & \\
\hline Tổng & $\begin{array}{c}60 \\
(84,5)\end{array}$ & $\begin{array}{c}11 \\
(15,5)\end{array}$ & $\begin{array}{c}71 \\
(100)\end{array}$ & \\
\hline
\end{tabular}

(*)Test khi bình phương

Triẹu chứng hay gặp trong nhóm COVID-19 là sốt chiếm $45 \%$, trong nhóm sốt rét là $90,1 \%$, sự khác biệt giữa 2 nhóm có ý nghĩa thống kê với $p<0,05$. Triệu chứng ho khan gặp chủ yếu ở nhóm COVID-19 (75\%) cao hơn nhiều nhóm Sốt rét $(27,3 \%)$, sự khác biệt có ý nghĩa thống kê với $p<0,05$.

\section{2. Đặc điểm cận lâm sàng}

Bảng 3.2. Đặc điểm cận lâm sàng của nhóm nghiên cứu

\begin{tabular}{|c|c|c|c|}
\hline $\begin{array}{c}\text { Chỉ số cận lâm } \\
\text { sàng }\end{array}$ & $\begin{array}{c}\text { COVID- } \\
\mathbf{1 9 ( I Q R ,} \\
\text { n=60) }\end{array}$ & $\begin{array}{c}\text { Sốt rét } \\
\text { (IQR, } \\
\text { n=11) }\end{array}$ & $\mathbf{p}$ \\
\hline Hồng cầu $(\mathrm{T} / \mathrm{L})$ & 4,58 & 4,74 & 0,975 \\
\hline Bạch cầu $(\mathrm{G} / \mathrm{L})$ & 5,61 & 5,45 & 0,187 \\
\hline Tiểu câu $(\mathrm{G} / \mathrm{L})$ & 222,5 & 35 & 0,014 \\
\hline CD4 $\left(\mathrm{TB} / \mathrm{mm}^{3}\right)$ & 748,28 & 812,67 & 0,428 \\
\hline Ure $(\mathrm{mmol} / \mathrm{L})$ & 4,4 & 5,4 & 0,03 \\
\hline Creatinine $(\mu \mathrm{mol} / \mathrm{L})$ & 68 & 82,45 & 0,027 \\
\hline
\end{tabular}




\begin{tabular}{|c|c|c|c|}
\hline AST (UI/L) & 24 & 28,4 & 0,324 \\
\hline ALT (UI/L) & 17 & 26,4 & 0,141 \\
\hline CRP (mg/l) & 1,5 & 69,5 & 0,06 \\
\hline Procalcitonin(ng/ml) & 0,028 & 1,715 & 0,02 \\
\hline PT(\%) & 88 & 66,5 & 0,008 \\
\hline Fibrinogen(g/L) & 5,24 & 4,36 & 0,715 \\
\hline APTT(giây) & 33,1 & 38 & 0,021 \\
\hline INR (giây) & 1,08 & 1,31 & 0,049 \\
\hline D-dimer (ng/mL) & 733 & 2829 & 0,002 \\
\hline
\end{tabular}

Bệnh nhân sốt rét có tình trạng rối loạn đông máu nhiêu hơn bệnh nhân COVID-19 với các chỉ số Tiểu cầu thấp (IQR: $35 \mathrm{G} / \mathrm{L}$ so với $222,5 \mathrm{G} / \mathrm{L}$ ), với $\mathrm{p}=0,014$; D-dimer tăng cao (IQR: 2829 $\mathrm{ng} / \mathrm{ml}$ so với $733 \mathrm{ng} / \mathrm{ml})$, với $\mathrm{p}=0,002$. Procalcitonin ở bệnh nhân sốt rét tăng cao hơn bệnh nhân COVID-19 (IQR: 1,715ng/ml so với $0,028 \mathrm{ng} / \mathrm{ml})$ với $\mathrm{p}=0,02$.

\subsection{Một số đặc điểm khác}

Bảng 3.3. Thời gian thanh thải virus và KST

\begin{tabular}{|c|c|c|c|}
\hline & $\begin{array}{c}\text { Trung } \\
\text { bình }\end{array}$ & SD & $\underset{\min }{\operatorname{Max}-}$ \\
\hline \multicolumn{4}{|c|}{ Kí sinh trùng sốt rét $(n=11)$} \\
\hline $\begin{array}{l}\text { Số lượng KST } \\
\text { (KST/ul) }\end{array}$ & 11.651 & 11.385 & $\begin{array}{c}34.160- \\
280\end{array}$ \\
\hline Thời gian sach (ngày) & 4,18 & 2,09 & $8-1$ \\
\hline \multicolumn{4}{|c|}{ COVID-19 $(n=60)$} \\
\hline $\begin{array}{l}\text { Thời gian thanh thải } \\
\text { virus SARS-CoV2 }\end{array}$ & 8,22 & 4,83 & $24-3$ \\
\hline $\begin{array}{c}\text { CT scan ngực } \\
(n=60)\end{array}$ & Số lượng & \multicolumn{2}{|c|}{ Tỷ lệ \% } \\
\hline Tốn thương phổi & 45 & & 75 \\
\hline Tổn thương 1 bên & 9 & & 20 \\
\hline Tốn thương 2 bên & 36 & & 80 \\
\hline
\end{tabular}

Thời gian sạch KST sốt rét trong máu là 4,18 $\pm 2,09$ ngày. Thời gian thanh thải virus SARSCoV2 là $8,22 \pm 4,83$ ngày. $75 \%$ bệnh nhân COVID-19 có tổn thương phổi trên CT ngực, trong đó $80 \%$ là tổn thương 2 bên.

\section{BÀN LUẬN}

4.1. Đặc điểm nhóm nghiên cứu. Trong 71 bệnh nhân nghiên cứu chúng tôi gặp nữ giới nhiều hơn nam giới, chiếm tỷ lệ $54,9 \%$. Trong đó, tuổi trung bình của nhóm nghiên cứu là 39,55 tuổi (trẻ nhất 17 tuổi, cao nhất 83 tuổi). Các bệnh nhân chủ yếu là người Việt Nam 62/71 (chiếm tỷ lệ $87,3 \%$ ), còn lại là quốc tịch Anh, Pháp, Đức, Mỹ. Đa số bệnh nhân đầu tiên này là du học sinh và người lao động từ nước ngoài về.

Thời gian ủ bệnh của bệnh nhân trong nghiên cứu của chúng tổi là $6,53 \pm 4,9$ ngày. Các nghiên cứu tại Trung Quốc cho thấy, thời gian ủ bệnh trung bình của bệnh nhân COVID-19 là 5,2 ngày [6]. So với các nghiên cứu này, nghiên cứu của chúng tôi có có cõ̃ mẫu nhỏ hơn, nên cần thêm thông tin về những nghiên cứu tiếp theo ở Việt Nam trong thời gian tới.

4.2. Đặc điểm lâm sàng. Triệu chứng phổ biến của bệnh nhân sốt rét là sốt với tỷ lệ gặp 90,1\%, trong khi đó chỉ có $45 \%$ bệnh nhân COVID-19 trong nghiên cứu có biểu hiện này, sự khác biệt giữa 2 nhóm có ý nghĩa thống kê với $p$ $=0,005$ (Bảng 3.1). Một báo cáo tổng hợp từ 152 nghiên cứu, với 41,409 bệnh nhân cho thấy tỷ lệ sốt của BN COVID-19 là 58,66\% [8]. Điêu này cho thấy, sốt không phải là triệu chứng điển hình và thường gặp của bệnh nhân COVID-19. Bởi vậy, khi bệnh nhân nghi ngờ nhiễm SARS$\mathrm{CoV} 2$ nếu có yểu tố đi về từ vùng dịch tễ thì các bác sĩ lâm sàng không nên bỏ sót việc tìm kí sinh trùng sốt rét. Trong nghiên cứu của chúng tôi, 11 bệnh nhân sốt rét nằm trong số 219 công nhân trở về từ Guinea xích đạo, một quốc gia Tây Phi, 120 trong số này đã được chẩn đoán nhiễm SARS-CoV2, trong quá trình điều trị chúng tôi nhận thấy nhiều bệnh nhân có biểu hiện sốt cao dai dẳng nên đã cho làm thêm xét nghiệm tìm KST sốt rét, kết quả cho thấy có $11 \mathrm{ca}$ dương tính với Plasmodium falcipalrum. Ho cũng là một triệu chứng có thể gặp trong bệnh nhân COVID19 vì bệnh lây qua đường hô hẩp, virus tác động trực thiếp lên các tế bào biểu mô đường hô hấp nơi có nhiều thụ thể $A C E 2$, triệu chứng này trong bệnh nhân sốt rét ít gặp hơn. Trong nghiên cứu của chúng tôi $75 \%$ bệnh nhân COVID-19 có biểu hiên ho và $27,3 \%$ (3/11) bênh nhân sốt rét cũng có biểu hiện này. Biểu hiện ho của bệnh nhân COVID-19 trên Thế giới là 54,52\% [8]. Ngoài ra, trong nghiên cứu của chúng tôi các triệu chứng đau đâu, đau mỏi cơ ở bệnh nhân sốt rét gặp với tỷ lệ cao hơn bệnh nhân COVID-19 (Bảng 3.1). Các nghiên cứu trên thế giới đều cho thây triệu chứng đau đâu, đau mỏi cơ là những biểu hiện ít gặp trên bệnh nhân COVID-19 lần lượt chiếm tỷ lệ $12,17 \%$ và $16,9 \%$ [8]. Tỷ lệ này trong nghiên cứu của chúng tôi là $11,7 \%$ và $6,7 \%$. Một điều đặc biệt là trong nghiên cứu của chúng tổi $8 / 60$ (chiếm 13,3\%) bệnh nhân COVID-19 không có bất kì một dấu hiệu lâm sàng nào, bệnh nhân được xét nghiệm do có yếu tố nguy cơ. Điều này có ý nghĩa quan trọng trong xác định những ca bệnh nghi ngờ cũng như xét nghiệm cho các đối tượng nguy cơ tại Việt Nam. Một số triệu chứng ít gặp hơn như đau rát họng $(31,1 \%)$, chảy nước mũi $(3,3 \%)$, ỉa chảy $(20 \%)$ cũng cho kết quả tương tự như những nghiên cứu khác trên thế giới. Một điểm đặc biệt trong những bệnh nhân nhiễm SARS-CoV2 này là không gặp bệnh nhân 
nào có biểu hiện hắt hơi, là các triệu chứng thường được nhắc tới trong nhiếm virus cúm, thì lại rất ít hoặc không thấy trên nhóm bệnh nhân COVID-19 này.

4.3. Đặc điểm cận lâm sang. Đa số các bệnh nhân có Hồng cầu và Bạch cầu máu trong giới hạn bình thường với trung vị tương ứng 4,58 $\mathrm{T} / \mathrm{L}$ và $5,61 \mathrm{G} / \mathrm{L}$ ơ nhóm COVID-19; 4,74 $\mathrm{T} / \mathrm{L}$ và 5,45 G/L ở nhóm Sốt rét, sự khác biệt không có ý nghĩa thống kê với $p>0,05$. Nghiên cứu của Guan và cộng sự (2020) cho thấy 1099 bệnh nhân COVID-19 có kết quả bạch cầu và tiểu câuu máu trong giới hạn bình thường (Trung bình tương ứng là $4,6 \mathrm{G} / \mathrm{L}$ và $168 \mathrm{G} / \mathrm{L}$ ). Trong nghiên cứu của chúng tôi, số lượng tiểu cầu trong nhóm sốt rét có sự giảm đáng kể (IQR: $35 \mathrm{G} / \mathrm{L}$ ) so với nhóm BN COVID-19 (IQR: 22,5 G/L) với $p=$ 0,014 . Hiện tượng giảm tiểu cầu cũng được ghi nhận ở bệnh nhân sốt rét. Kết quả trong nghiên cứu của chúng tôi cũng cho thây sự tương đồng nhất định khi bệnh nhân sốt rét cũ̃ng ghi nhận hiện tượng giảm tiểu cầu trong máu. Số lượng tế bào CD4 trong 2 nhóm không có sự khác biệt. Một số quan điểm cho rằng, giảm $\mathrm{CD} 4$ là một trong những yếu tố tiên lượng bệnh nhân nặng, điều này cần một nghiên cứu với cỡ mẫu lớn hơn vì trong nghiên cứu của chúng tôi, đa phần các bệnh nhân đều nhẹ và trung bình, không có bệnh nhân nào cần can thiệp thở máy hay lọc máu hấp phụ cytokin. Các chỉ số về sinh hoá máu như nồng độ Ure, creatinin, men gan của 2 nhóm nghiên cứu đều trong giới hạn bình thường và không có sự khác biệt giữa a nhóm.

Về các biểu hiện nhiễm trùng, chúng tôi nhận thấy tình trạng tăng CRP và PCT ở những bệnh nhân sốt rét cao hơn hẳn ở nhóm COVID-19. Về chỉ số nhiễm trùng PCT, trung vị ở nhóm COVID19 là $0,028 \mathrm{ng} / \mathrm{ml}$ thấp hơn hẳn nhóm sốt rét là $1,715 \mathrm{ng} / \mathrm{ml}$ với $\mathrm{p}=0,008$ (Bảng 3.2). Trung vị CRP ở nhóm COVID-19 là $1,5 \mathrm{mg} / \mathrm{l}$, ở nhóm sốt rét là $69,5 \mathrm{mg} / \mathrm{l}$, tuy nhiên sự khác biệt này không có ý nghĩa với $p=0,06$. Các nghiển cứu cho thây bệnh nhân COVID-19 thường có chỉ số PCT trong giới hạn bình thường (94,5\%). Đây là một đặc điểm cận lâm sàng đáng lưu ý cho thấy sinh bệnh học khác biệt giữa COVID-19 và sốt rét. Rối loạn đông máu trong COVID-19 được đề cập rất sớm và là một trong những cơ chế sinh bệnh học quan trọng giúp các nhà nghiên cứu cũ̃ng như các nhà lâm sàng có những can thiệp chống đông kịp thời và phù hợp nhằm làm giảm tỷ lệ biến chứng nặng cũng như tỷ lệ tử vong của bệnh nhân. Khi so sánh tình trạng rối loạn đông máu giữa 2 nhóm bệnh trong nghiên cứu, chúng tôi nhận thấy bệnh nhân sốt rét có những biểu hiện rối loạn đông máu nặng nề hơn nhóm COVID-19. Cụ thể, chỉ số trung vị của Prothombin trong nhóm COVID-19 là $88 \%$, cao hơn nhóm sốt rét là $66,5 \%(p=0,008)$, $D$-dimer của nhóm sốt rét cao hơn hẳn nhóm COVID-19 tương ứng là $2.829 \mathrm{ng} / \mathrm{ml}$ so với $733 \mathrm{ng} / \mathrm{ml}$ với $\mathrm{p}=0,002$ (Bảng 3.2). Điều này cho thấy trong sốt rét các rối loạn đông máu thường gặp và đáng được quan tâm, các bác sĩ lâm sàng cần theo dõi sát và can thiệp chống đông kịp thời nhằm giảm tỷ lệ biến chứng chảy máu nặng cũng như tỷ lệ tử vong của bệnh nhân sốt rét. Trong nghiên cứu này của chúng tôi, hầu hết bệnh nhân COVID-19 là ở thể nhẹ (theo định nghĩa thể bệnh của Bộ Y tế năm 2021) nên các biểu hiện về rối loạn đồng máu ít nặng nề hơn những bệnh nhân COVID-19 nặng. Cần có thêm những nghiên cứu đánh giá những rối loạn đông máu trên bệnh nhân COVID-19 nặng để có thêm bức tranh tổng quan về tình trạng này trên BN COVID-19 nói chung.

4.4. Một số đặc điểm khác. Trong nghiên cứu của chúng tôi, $100 \%$ bệnh nhân sốt rét thể P. falciparum với số lượng KST trung bình 11.651 $\mathrm{KST} / \mu \mathrm{L}$, thời gian sạch KST trong máu trung bình 4,18 ngày, thuốc sử dụng điêu trị là Artesunat phối hợp với Arterakin. Không gặp bệnh nhân sốt rét nào có tổn thương phổi. Với nhóm COVID-19, thời gian thanh thải virus là $8,22 \pm 4,83$ ngày. Thời gian này thấp hơn nhiều so với các nghiên cứu trên thế giới, một số nghiên cứu thây thời gian thanh thải virus trung bình là $22,5 \pm 9,3$ ngày. Điều này có thể được giải thích do bệnh nhân trong nghiên cứu của chúng tôi chủ yếu trong độ tuổi trẻ (trung bình 39 tuổi), đa số các bệnh nhân không có bệnh lý nền nên thời gian thanh thải virus cũng ngắn hơn. Tác giả Fei Zhou và cộng sự (2020) nghiên cứu trên 191 bệnh nhân COVID-19 nhận thây, thời gian thanh thải virus là 20 ngày, các yếu tố tuổi cao, bênh lý nền, đặc biệt là các bệnh lý tim mạch là những yếu tố tiên lượng bệnh nhân tử vong. Tổn thương phổi trền phim CT ngực gặp ở 45/60 bệnh nhân (chiếm tỷ lệ 75\%), tổn thương phổi chủ yếu gặp tổn thương 2 bên chiếm tỷ lệ $80 \%$, chủ yếu tổn thương vùng giữa và đáy phổi 2 bên. Kết quả này tương tự như nghiên cứu của Nanshan Chen (2020) cho thấy tổn thương phổi trên CTscan ngực và Xquang cũng chủ yếu là tổn thương phổi 2 bên với tỷ lệ 75\% [5]. Đặc điểm tổn thương phổi do SARS-CoV2 có một số điểm khác so với các tổn thương phổi do virus khác, mặc dù tổn thương chủ yếu ở thuỳ giữa và đáy phổi nhưng tổn thương ban đầu xuất hiện các 
nốt dạng kính mờ vùng ngoại vi, sau tiến triển lan thành các đám, mảng, lan từ ngoại vi vào trung tâm. Một số báo cáo khi sinh thiết phổi ở bênh nhân COVID-19 tử vong thì tổn thương chủ yểu ở phế nang là tổn thương lan toả với dịch tiết và lympho bào cũng như đại thực bào, được cho là có liên quan đến hình ảnh các tổn thương kính mờ trên phim chụp phổi.

\section{KẾT LUÂ̂N}

- 71 bệnh nhân trong nghiên cứu, tuổi trung bình là 39,5 tuổi, nam và nữ gặp tương đương nhau. Thời gian ủ bệnh trung bình của bệnh nhân COVID-19 là 6,53 $\pm 4,07$ ngày. Thời gian thanh thải virus: $8,22 \pm 4,83$ ngày. Thời gian sạch KST sốt rét trong máu là 4,18 $\pm 2,09$ ngày. $100 \%$ bệnh nhân điều trị khỏi.

- Triệu chứng sốt hay gặp ở nhóm sốt rét $(90,1 \%)$, cao hơn nhóm COVID-19 (45\%). Ho gặp chủ yếu ở nhóm BN COVID-19. Không nên bỏ qua bệnh sốt rét trong vụ dịch COVID-19 nếu bệnh nhân có yếu tố dịch tễ đi về từ vùng dịch

- Giảm tiểu câuu và rối loạn đông máu là các biểu hiện thường gặp ở bệnh nhân sốt rét. Tăng $\mathrm{PCT}$ và $\mathrm{CRP}$ ở bệnh nhân sốt rét nhiều hơn ở bệnh nhân COVID-19 nhe

$-75 \%$ bệnh nhân có tổn thương phổi trên phim CT ngực, chủ yếu tổn thương 2 bên ( $80 \%)$
TÀI LIỆ THAM KHẢO

1. WHO, Rolling update on coronavirus diseases (COVID-19). 2020.

2. Wei-jie Guan, P.D., et al., Clinical characteristics of 2019 novel coronavirus infection in China. medRxiv preprint doi: https://doi.org/ 10.1101/2020.02.06.20020974, 2020.

3. World Health Organization, WHO World Malaria Report 2019. [(accessed on 16 July 2020)]; Available online: https://www.who.int/ publications/i/item/9789241565721.

4. Chaolin Huang*, et al., Clinical features of patients infected with 2019 novel coronavirus in Wuhan, China. The Lancet 2020( https://doi.org/10.1016/S0140-6736(20)30183-5).

5. Nanshan Chen*, et al., Epidemiological and clinical characteristics of 99 cases of 2019 novel coronavirus pneumonia in Wuhan, China: a descriptive study. The Lancet, 2020(Published online January 29,2020 https://doi.org/10.1016/S0140-6736(20)30211-7).

6. Wu, Y.C., C.S. Chen, and Y.J. Chan, Overview of The 2019 Novel Coronavirus (2019-nCoV): The Pathogen of Severe Specific Contagious Pneumonia (SSCP). J Chin Med Assoc, 2020.

7. Di Gennaro, F., et al., Malaria and COVID-19: Common and Different Findings. Tropical medicine and infectious disease, 2020. 5(3): p. 141.

8. da Rosa Mesquita, R., et al., Clinical manifestations of COVID-19 in the general population: systematic review. Wiener klinische Wochenschrift, 2021. 133(7-8): p. 377-382.

\title{
THIẾU KẼM VẤN ĐỀ Ý NGHĨA SỨC KHỎE CộNG ĐỒNG VÀ MộT SỐ YẾU TỐ LIÊN QUAN Ở PHỤ NỮ TUỔI SINH ĐỂ TẠI MộT TỈNH VÙNG TÂY BẮC Bộ, NĂM 2018
}

\author{
Nguyễn Song Tú ${ }^{1}$, Hoàng Văn Phương ${ }^{2}$, \\ Nguyễn Hồng Trường ${ }^{1}$, Trần Thúy $\mathrm{Nga}^{1}$, Hoàng Long Quân ${ }^{3}$
}

\section{TÓM TẮT}

Trong nhiều thập kỷ qua, thiếu kẽm là một tình trạng thiếu vi chất dinh dưỡng phổ biến nhất ở Việt Nam. Nghiên cứu mô tả cắt ngang tiến hành trên 809 phụ nữ 15 - 35 tuổi tại Sơn La, thuộc khu vực Tây Bắc Bộ để xác định tịnh trạng thiếu kẽm và một số yếu tổ liên quan. Kết quả cho thấy tỷ lệ thiếu kểm ở phụ nữ $15-35$ tuổi là $86,8 \%$. Nồng độ kẽm huyết thanh trung bình là $9,56 \pm 1,5 \mu \mathrm{mol} / \mathrm{L}$. Tỷ lề thiếu kẽm ở nhóm 15 - 24 là 84,0\% thấp hơn có ý nghĩa

${ }^{1}$ Viện Dinh dưỡng Quốc gia, Hà Nội

'Cực Y tế dự phòng, Bộ Y tế

${ }^{3}$ Trường Đại hoc Y Hà Nội

Chịu trách nhiệm chính: Nguyễn Song Tú

Email: nguyensongtu@yahoo.com

Ngày nhận bài: 14.6.2021

Ngày phản biện khoa học: 9.8.2021

Ngày duyệt bài: 16.8.2021 thống kê so với nhóm 25 - 35 tuổi $(89,1 \%)$. Có tương quan thuận chiều giữa nồng độ hemoglobin và retinol huyết thanh với nồng độ kễm huyết thanh $(p<0,01)$. Thiếu năng lượng trường diễn, tình trạng vitamin $A$ và tiền sử sốt có liến quan đối với tình trạng thiếu kẽm $(p<0,05)$. Thiếu kẽm là vấn đề có ý nghĩa sức khỏe cộng đồng nghiêm trọng ở phụ nữ tuổi sinh đẻ tỉnh Sợn La, cần có giải pháp tích cực và tổng thể trong cải thiện tình trạng thiếu kẽm nói riêng và phối hợp phờng chống thiếu vi chất dinh dưỡng nói chung tại các vùng miền núi, đặc biệt vùng nghèo, vùng khó khăn.

Tư khoá: thiếu kẽm, thiếu vi chất dinh dưỡng, phụ nữ tuổi sinh đẻ, yếu tố liên quan

\author{
SUMMARY \\ ZINC DEFICIENCY IS A PUBLIC HEALTH \\ PROBLEM AND SOME RELATED FACTORS \\ IN WOMEN OF REPRODUCTIVE AGE IN A \\ PROVINCE IN THE NORTH WEST REGION, 2018
}


For decades, zinc deficiency has been the most common micronutrient deficiency in Vietnam. A crosssectional study was conducted on 809 women aged 15-35 years old in Son La, in the Northwest region to determine zinc deficiency and some related factors. Results showed that the prevalance of zinc deficiency in women $15-35$ years old was $86.8 \%$. The mean serum zinc concentration was $9.56 \pm 1.5 \mu \mathrm{mol} / \mathrm{L}$. The prevalence of zinc deficiency in the group 15-24 was $84.0 \%$ statistically significant lower than that in the group of $25-35$ years old $(89.1 \%)$. There was a positive correlation bettwen hemoglobin concentration and serum retinol with serum zinc concentration $(p<$ 0.01 ). Chronic Energy deficiency, vitamin A status and history of fever were related to the zinc deficiency status $(p<0.05)$. Zinc deficiency is a serious public health problem in women of reproductive age in Son La province. There is a need for positive and comprehensive solutions to improve zinc deficiency in particular and combination the micronutrient deficiencies in general in mountainous areas, especially in poor and disadvantaged areas.

Keywords: zinc deficiency, micronutrient deficiency, women of reproductive age, related factors

\section{I. ĐĂT VẤN ĐỀ}

Trên thế giới và Viêt Nam, thiếu kẽm là một tình trang thiếu vi chất dinh dưỡng phổ biến, có ý nghĩa sức khỏe cộng đồng (YNSKCĐ). Nguyên nhân cơ bản nhất khiến tỷ lệ thiếu kẽm cao là do cơ thể con người không thể dự trữ kẽm, do đó sự thiếu hưt có thể phát sinh nhanh chóng do chế độ ăn uống không hợp lý, hoặc nhu cầu kẽm tăng cao do yếu tố sinh lý hoặc mắc nhiếm khuẩn. Ước tính có khoảng $17,3 \%$ dân số thế giới có nguy cơ thiếu kẽm [1]. Thiếu kẽm ảnh hưởng đến hơn 2 tỷ người ở các nước phát triển. Tỷ lệ thiếu kẽm ở phụ nữ tuổi sinh đẻ (PNTSĐ)là rất cao nhưng khác biêt giữa các nước như Ethiopia (2017) là 34\%, Cameroon là 81,6\% [2], Vùng trung tâm của Kongo của Công Gô (2016) là $58,0 \%$, ở phụ nữ nông thôn ở Ấn Độ (2011) là $52 \%$, ở phụ nữ không mang thai và không cho con bú Bangladesh (2017) là (57\%). Ở Viêt Nam điều tra quốc gia 2010 cho thấy tỷ lệ thiếu kẽm PNTSĐ rất cao $67,2 \%$, không khác biệt giữa nông thôn và thành thị [3]; Tỷ lệ thiếu kẽm ở PNTSĐ chung trong điêu tra 3 miền của Viêt Nam giảm chậm, điêu tra năm 2015 cho thây là $63,6 \%$, trong đó nông thôn là $60,3 \%$ và miền núi là $73,4 \%$ ở mức cao có YNSKCĐ [4]. Thiếu kẽm có thể làm suy giảm chức năng miễn dịch và góp phần vào gánh nặng toàn cầu của các bệnh truyền nhiễm bao gôm tiêu chảy, viêm phổi và̀ sốt rét (Ackland $M L, 2016)$. Các yếu tố liên quan đến tình trạng thiếu kẽm như chế độ ăn, nhóm tuổi, tình trạng sinh lý hoặc sự xuất hiện của bệnh lý; hay khu vực địa lý thường gặp ở vùng nông thôn; hoàn cảnh kinh tế [2]. Ăn ít thức ăn nguồn gốc động vật và chế độ ăn không đủ đa dạng (Berhe K); chỉ số chất lượng nhà ở, chỉ số chu vi vòng cánh tay cũng là yếu tố được kể đến.

Phụ nữ tuổi sinh đẻ vùng nghèo, vùng miền núi thường là đối tượng có nguy cơ thiếu kẽm cao do chế độ ăn nghèo nàn và nhu cầu tăng cao hơn về chất dinh dưỡng trong giai đoan mang thai và nuôi con bú. Chuẩn bị cho thể chất tốt và dinh dưỡng đầy đủ cho phụ nữ giai đoạn tiền mang thai cũng rất quan trong. Để có đinh hướng can thiệp phù hợp cho đối tượng này, nghiên cứu được tiến hành nhằm đánh giá thực trạng thiếu kẽm và những yếu tố liên quan ở PNTSĐ vùng miền núi của một tỉnh Tây Bắc Bộ.

\section{II. ĐỐI TƯợNG VÀ PHƯƠ'NG PHÁP NGHIÊN CứU 2.1 Đối tượng nghiên cứu \\ Tiêu chuẩn lựa chon: Phu nữ độ tuổi 15-} 35, không nuôi con bú < 12 tháng hoặc không có thai. Đồng ý tham gia.

2.2. Địa điểm và thời gian nghiên cứu

Tại 10 xã của huyện Thuận Châu và Mường La, tỉnh Sơn La trong thời gian từ tháng 07/2018 đến tháng 12/2018.

2.3. Thiết kế nghiên cứu. Mô tả cắt ngang

2.4. Cỡ mẫu: Ap dụng công thức:

$$
\mathrm{n}=\frac{\mathrm{z}^{2}(1-\mathrm{a} / 2) \times \mathrm{p}(1-\mathrm{p}) \times \mathrm{DE}}{\mathrm{d}^{2}}
$$

Trong đó: n là số đối tượng cân điều tra, p là tỷ lê thiếu kẽm ở phụ nữ vùng miền núi năm 2015 là 73,4\% [4]; chọn $d=0,05 ; z$ có giá trị là 1,96 (301 đối tượng). $\mathrm{DE}=1,3$; Cõ mẫu cần chung là 391 đối tượng x 2 huyện x 5\% bỏ cuộc $=821$ đối tượng. Thực tế điều tra 809 đối tượng.

\subsection{Phương pháp chọn mẫu}

Chọn tỉnh: Chọn chủ đích huyện Thuận Châu và Mường La, tỉnh Sơn La một tỉnh miền núi phía Bắc, nơi có hoàn cảnh kinh tế khó khăn.

Chọn xã: Chọn ngẫu nhiên đơn $5 / 9$ xã thuộc xã nghèo, huyện Mường La (xã Chiềng Lao, Nậm Giôn, Mường Trai, Hua Trai, Ngọc Chiến) và $5 / 27$ xã nghèo thuộc huyện Thuận Châu (xã Chiềng Bôm, Nậm Lầu, Tông Lạnh, Chiềng Pha, Mường Khiêng).

Chọn đối tượng nghiên cứu: theo phương pháp ngẫu nhiên hệ thống

\subsection{Phương pháp và công cụ thu thập số liệu}

Phỏng vấn: sử dụng bộ câu hỏi được thử nghiệm trước khi điêu tra.

Cần đo nhân trắc: Cân điện tử TANITA SC 
330 với độ chính xác $0,1 \mathrm{~kg}$ đo được \% mõ cơ thể. Đo chiều cao đứng sử dụng thước gỗ 3 mảnh có độ chính xác tới $1 \mathrm{~mm}$.

Xét nghiệm máu: Kẽm huyết thanh định lượng theo phương pháp quang phổ hấp phụ nguyên tử (AAS). Vitamin $A$ huyết thanh bằng phương pháp HPLC (WHO, 1996). Nồng độ Ferritin huyết thanh (SF) bằng phương pháp ELISA. Định lượng Hemoglobin $(\mathrm{Hb})$ trong máu bằng phương pháp Cyamethemoglobin, dùng máy Hemocue; Các mẫu đã được phân tích tại labo vi chất, Viện Dinh dưỡng.

2.7. Một số tiêu chuẩn xác định, đánh giá

Chỉ số khối cơ thể (BMI): được tính bằng cân nặng/(chiều cao $)^{2}$ đơn vị $\left(\mathrm{kg} / \mathrm{m}^{2}\right)$.

Đánh giá: Thiếu kẽm xác định khi nồng độ kẽm trong máu (buổi sáng) <10,1 $\mu \mathrm{mol} / \mathrm{L}$ (IZiNCG 2012); thiếu kẽm ở ngưỡng rất cao có YNSKCĐ theo IZiNCG là trên $20 \%$; retinol huyết thanh $<1,05 \mu \mathrm{mol} / \mathrm{l}$ là thiếu vitamin $A$ tiền lâm sàng (VAD - TLS) và nguy cơ; Dự trữ sắt thấp khi ferritin huyết thanh < $30 \mu \mathrm{g} / \mathrm{l}$; Thiếu máu khi hemoglobin < $120 \mathrm{~g} / \mathrm{l}$ (WHO 2001).

\subsection{Biến số, chỉ số nghiên cứu}

- Nồng độ kêm huyết thanh trung bình và tỷ lệ thiếu kẽm chung; theo nhóm tuổi; nhóm đối tượng (cân nặng thấp, CED, BMI, \% mõ cơ thể, thiếu vi chất).

- Yễu tố liên quan đối: các yễu tố nhân khẩu học, tiền sử bệnh tật, tình trạng dinh dưỡng, vi chất dinh dưỡng, tiền sử dùng thuốc

2.9. Phân tích và xử lý số liệu. Sử dụng phần mềm Epi Data 3.1 để nhập liệu và SPSS 18.0 để phân tích. Test kiểm định thống kê là $\chi^{2}$ test, $\mathrm{t}$ test, ANOVA test. Giá trị $\mathrm{p}<0,05$ được xem có ý nghĩa thống kê. Tương quan tuyến tính với nồng độ vitamin $A$, kẽm và hemoglobin phân bố chuẩn (test Pearson) và ferritin phân bố không chuẩn (test Spearman); Hồi qui losgistic đa biến dự đoán yếu tố liên quan.

2.10. Đạo đức nghiên cứu. Nghiên cứu đã được chấp thuận bởi Hội đồng đạo đức của Viện Dinh dưỡng trước khi triển khai, theo quyết định số 1474 /QĐ-VDD ngày 14/09/2018.

\section{KẾT QUẢ NGHIÊN CỨU}

Nghiên cứu đã tiến hành trên 809 đối tượng nghiên cứu (ĐTNC) tại 10 xã của tỉnh Sơn La, trong đó chủ yếu là dân tộc Thái chiếm $86,5 \%$. Tuổi trung bình (TB) là 25,0 $\pm 6,5$. Có 46,6\% ĐTNC thuộc hộ gia đình nghèo; $20,9 \%$ là cận nghèo; $81,7 \%$ ĐTNC có nghề nghiệp chính là làm ruộng; $14,7 \%$ ĐTNC là học sinh.

Bảng 1. Nồng độ kẽm huyêt thanh và tỷ lệ thiêu kẽm ở ĐTNC theo nhóm tuổi (n=809)

\begin{tabular}{|c|c|c|c|c|}
\hline Nhóm tuổi & $\mathbf{n}$ & $\begin{array}{c}\text { Số thiếu } \\
\text { kẽm }\end{array}$ & $\begin{array}{c}\text { Tỷ lệ thiếu kẽm } \\
(\mathbf{\%})^{\mathbf{b}}\end{array}$ & $\begin{array}{c}\text { Nồng độ kẽm huyết thanh } \\
(\mathbf{T B} \pm \mathbf{S D})(\boldsymbol{\mu m o l} \mathbf{m})\end{array}$ \\
\hline $15-24$ tuối & 368 & 309 & $84,0^{\text {b1 }}$ & $9,71 \pm 1,43^{\mathrm{c}}$ \\
\hline $25-35$ tuối & 441 & 393 & 89,1 & $9,43 \pm 1,59$ \\
\hline $15-19$ tuối & 203 & 174 & $85,7^{\mathrm{b} 1}$ & $9,70 \pm 1,24$ \\
\hline $20-24$ tuối & 165 & 135 & 81,8 & $9,72 \pm 1,64$ \\
\hline $25-29$ tuối & 202 & 175 & 86,6 & $9,58 \pm 1,65$ \\
\hline $30-35$ tuối & 239 & 218 & 91,2 & $9,29 \pm 1,52^{\text {a1 }}$ \\
\hline Chung & $\mathbf{8 0 9}$ & $\mathbf{7 0 2}$ & $\mathbf{8 6 , 8}$ & $\mathbf{9 , 5 6} \pm \mathbf{1 , 5 2}$ \\
\hline
\end{tabular}

a) ANOVA-test với ${ }^{1} p<0,05 ;$ b) $\chi^{2}$ test với ${ }^{1} p<0,05 .{ }^{c)}$ t-test ${ }^{2} p<0,01$.

Tỷ lê thiếu kẽm ở ĐTNC là 86,8\%. Có sư khác biêt có YNTK về tỷ lệ thiếu kẽm và hàm lượng kẽm huyết thanh ở phụ nữ $15-35$ tuổi giữa 2 và 4 nhóm tuổi. Nhóm tuổi $30-35$ tuổi có hàm lượng kẽm thấp nhất, khác biệt có YNTK so với 3 nhóm tuổi còn lai (post hoc test, $p<0,05$ ).

Bảng 2. Mối liên quan giữa thiếu kêm với tình trạng dinh dướng và thiếu máu, thiếu vitamin A $(n=809)$

\begin{tabular}{|c|c|c|c|c|c|}
\hline Tình trạng & $\mathbf{n}$ & $\begin{array}{l}\text { Số thiếu } \\
\text { kẽm }\end{array}$ & $\begin{array}{l}\text { Tỷ lệ } \\
(\%)^{a}\end{array}$ & $\begin{array}{c}p^{b} \\
\text { OR }(95 \% \mathrm{CI})\end{array}$ & $\begin{array}{l}\text { Nồng độ kẽm huyết } \\
\text { thanh }(\mu \mathrm{mol} / \mathrm{L})^{\mathrm{c}}\end{array}$ \\
\hline Tình trang CED & 152 & 124 & 81,6 & $0,049^{b 1}$ & $9,80 \pm 1,4^{c 1}$ \\
\hline Bình thường & 657 & 578 & 88,0 & $0,61(0,38-0,97)$ & $9,50 \pm 1,5$ \\
\hline VAD và nguy cơ & 314 & 288 & 91,7 & $0, \mathbf{0 0 1}^{\mathrm{b} 3}$ & $9,31 \pm 1,4^{c 3}$ \\
\hline Bình thường & 495 & 414 & 83,6 & $2,17(1,34-3,46)$ & $9,71 \pm 1,6$ \\
\hline Thiếu máu & 210 & 187 & 89,0 & 0,312 & $9,35 \pm 1,4^{\mathrm{c} 1}$ \\
\hline Bình thường & 599 & 515 & 86,0 & $1,33(0,81-2,17)$ & $9,63 \pm 1,5$ \\
\hline
\end{tabular}

b) $\chi^{2}$ test; c) t-test; ${ }^{1)} \mathrm{p}<0,05{ }^{3)} \mathrm{p}<0,001$

Có khác biệt có YNTK về tỷ lệ thiếu kẽm ở nhóm CED và nhóm VAD -TLS và nguy cơ so với nhóm bình thường $(\mathrm{p}<0,05)$. Giá trị TB kẽm huyết thanh ở nhóm CED, VAD -TLS và nguy cơ, thiếu máu 
khác biêt có YNTK so với nhóm bình thường $(\mathrm{p}<0,05)$.

Bảng 3. Hồi qui logistic đa biến dự đoán các yêu tô liên quan với thiêu kẽm (n=809)

\begin{tabular}{|c|c|c|c|c|c|c|c|c|c|}
\hline \multirow{2}{*}{\multicolumn{3}{|c|}{$\begin{array}{l}\text { Các yếu tố trong mô hình } \\
\text { (Biến độc lập) }\end{array}$}} & \multicolumn{2}{|c|}{ UC* } & \multirow{2}{*}{\multicolumn{2}{|c|}{$\begin{array}{c}\text { OR } \\
\text { (Hiệu chỉnh) }\end{array}$}} & \multirow{2}{*}{\multicolumn{2}{|c|}{$95 \% \mathrm{CI}$}} & \multirow{2}{*}{ p } \\
\hline & & & $\beta$ & SE & & & & & \\
\hline \multicolumn{3}{|c|}{ Tình trạng CED (CED/bình thường*) } & $-0,56$ & 0,25 & 0,57 & & 0,35 & 0,93 & 0,026 \\
\hline \multicolumn{3}{|c|}{$\begin{array}{c}\text { Tình trạng vitamin } A \text { (VAD - TLS và nguy } \\
\text { cơ VAD-TLS/bình thường*) }\end{array}$} & 0,86 & 0,24 & 2,37 & & 1,48 & & 0,000 \\
\hline \multicolumn{3}{|c|}{$\begin{array}{l}\text { Trình độ học vấn (mù chũ̃ và cấp 1/từ } \\
\text { cấp } 2 \text { trở lên) }\end{array}$} & 0,44 & 0,25 & 1,55 & & 0,96 & 51 & 0,076 \\
\hline \multicolumn{3}{|c|}{ Sốt trong 4 tuânn qua (có sốt/không sốt*) } & $-0,52$ & 0,23 & 0,60 & & 0,38 & 0,94 & 025 \\
\hline \multicolumn{9}{|c|}{ 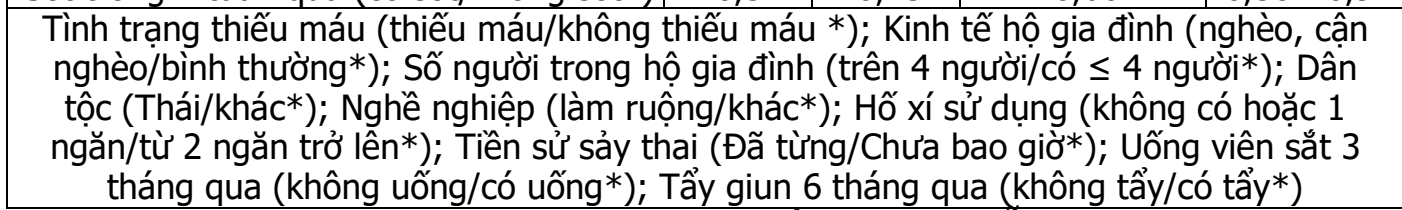 } & $>0,05$ \\
\hline \multicolumn{10}{|c|}{ 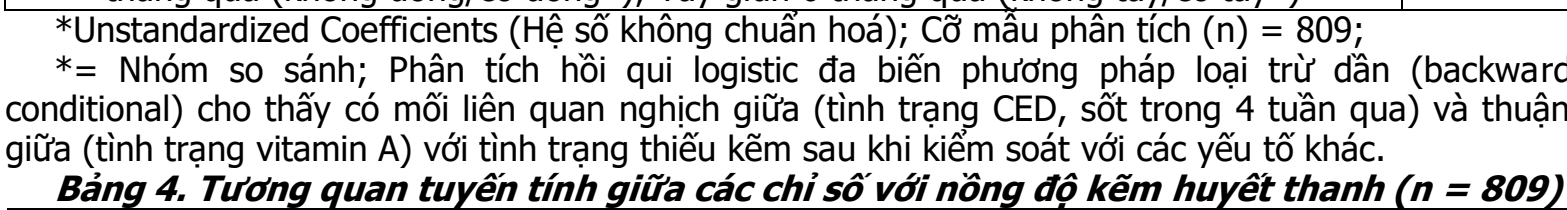 } \\
\hline $\begin{array}{l}\text { Các Biến } \\
\text { độc lập }\end{array}$ & $\begin{array}{l}\text { Retinol huyết } \\
\text { thanh }\end{array}$ & & $\begin{array}{l}\text { moglobi } \\
\text { thanh }\end{array}$ & & $\begin{array}{l}\text { erritin } \\
\text { êt thành }\end{array}$ & & MI & & $\begin{array}{l}\text { mỡ cơ } \\
\text { thể }\end{array}$ \\
\hline Tương quan & & & & & & & & & \\
\hline & & & 0,106 & & 12 & & & & \\
\hline$p$ & 0,000 & & 0,003 & & 0,735 & & 000 & &, 002 \\
\hline
\end{tabular}

2*: Tương quan Pearson; ${ }^{3 *}$ Tương quan Spearman

Nồng độ kẽm huyết thanh có tương quan tuyến tính thuận chiều tới hàm lượng retinol huyết thanh, hemoglobin; và ngược chiều với chỉ số BMI và \% mõ cơ thể $(p<0,01)$. tuy nhiên những sự tương quan này là sự tương quan yếu (với $r$ thấp nhất 0,106 cao nhất là 0,138 ).

Bảng 5. Tương quan đa biến tuyến tính một số chỉ số với nồng độ kêm huyêt thanh

\begin{tabular}{|c|c|c|c|c|}
\hline \multirow{2}{*}{$\begin{array}{c}\text { Các yếu tố trong mô hình } \\
\text { (Biến độc lập) }\end{array}$} & \multicolumn{2}{|c|}{ Hề số không chuấn hóa } & \multirow{2}{*}{$\begin{array}{l}\boldsymbol{\beta}(\mathrm{Hiêeu} \\
\text { chinh) }\end{array}$} & \multirow[b]{2}{*}{$\mathbf{p}$} \\
\hline & $\beta$ & SE & & \\
\hline Chỉ số \% mỡ cơ thế & $-0,04$ & 0,01 & $-0,14$ & 0,000 \\
\hline Hemoglobin & 0,01 & 0,00 & 0,10 & 0,006 \\
\hline Ferritin huyết thanh & 0,00 & 0,00 & $-0,01$ & 0,799 \\
\hline Retinol huyết thanh & 0,64 & 0,14 & 0,16 & 0,000 \\
\hline
\end{tabular}

Có tương quan tuyến tính thuận chiều giữa (hemoglobin, retinol huyết thanh) và ngược chiều giữa $\%$ mõ cơ thể với hàm lượng kẽm (linear regrestion, $R=0,22 ; R^{2}=0,042, p<0,001$ ).

\section{BÀN LUẬN}

Tỷ lệ thiếu kẽm ở ĐTNC là 86,8\% trong đó lứa tuổi cao nhất là nhóm 30 - 35 tuổi $(91,2 \%)$, ở ngưỡng rất cao (theo IZiNCG >trên 20\%) có YNSKCĐ; cao hơn tỷ lệ này ở PNTSĐ năm 2010 $(67,2 \%)[3]$; và ở PNTSĐ ở vùng nông thôn $(60,3 \%)$, cũng như cao hơn ở vùng miền núi $(73,4 \%)$ trong điều tra ba vùng năm 2015 [4]; đồng thời, cao hơn tỷ lệ ở PNTSĐ trong Tổng điều tra toàn quốc 2019 (63,5\%), và tỷ lệ ở cũng đối tượng này vùng miền núi phía Bắc $(81,9 \%)$ [5]; Nồng độ kẽm huyết thanh TB ở ĐTNC là $(9,56 \pm$ $1,5 \mu \mathrm{mol} / \mathrm{L}$ ), cao hơn nồng độ kẽm ở PNTSĐ miền núi $(8,1 \mu \mathrm{mol} / \mathrm{L})$ và vùng nông thôn $(9,3 \mu \mathrm{mol} / \mathrm{L})$ năm 2015 [4]; Điều đó cho thấy mặc dù nồng độ kẽm huyết thanh đã có sự tăng lên nhưng tỷ lệ thiếu kẽm trong gần 2 thập kỷ qua thay đổi không đáng kể, cho thấy khẩu phần kẽm trong chế độ ăn của phụ nữ miền núi đã được cải thiện; tuy nhiên tỳ lệ thiếu kẽm của PNTSĐ vùng Sơn La nói riêng và Việt Nam nói chung vẫn là vấn đề nghiêm trọng có YNSKCĐ, cần có giải pháp tích cực và tổng thể trong việc cải thiện, bao gồm cải thiện chế độ ăn (tăng cường sử dụng thức ăn nguồn gốc động vật giàu kẽm như thịt, cá, hải sản) và cần bổ sung kẽm định kỳ cho đối tượng nguy cơ cao để có thể cải thiện nhanh và bền vững tình trạng thiếu kẽm tại các vùng miền núi, đặc biệt vùng khó khăn, vùng nghèo.

Thiếu sắt có thể cùng tồn tại với sự thiếu hụt các nguyên tố vi lượng khác như kẽm, thường gặp ở các nước đang phát triển. Kẽm đóng vai 
trò là chất xúc tác trong quá trình chuyển hóa sắt trong hoạt động của enzym khử nước axit alpha-aminolevulinic, có vai trò trong quá trình tổng hợp heme (Ece A, 1997); Do đó, kết quả nghiên cứu tại Sơn La là hợp lý khi có tương quan thuận giữa nồng độ hemoglobin với kẽm huyết thanh; vì theo nghiên cứu của Soliman năm 2019 cho thấy nồng độ kẽm huyết thanh ở bênh nhân thiếu máu do thiếu sắt thấp hơn so với bệnh nhân không thiếu máu; lý do là sự hấp thu sắt bị suy giảm có thể do giảm các nguyên tố vi lượng như kẽm, được tìm thấy trong cấu trúc của các enzym điều phối hoặc xúc tác quá trình chuyển hóa sắt. Mối liên quan giữa thiếu kẽm và thiếu sắt có thể do thiếu dinh dưỡng của cả hai nguyên tố hoặc do kém hấp thu. Điều đó cho thấy nên can thiệp bổ sung cả sắt và kẽm trên đối tượng thiếu máu thiếu sắt thay vì chỉ bổ sung sắt đởn thuần.

Kẽm là một nguyên tố vi lượng cần thiết cho sự tăng trưởng, phát triển và duy trì chức năng miễn dịch [6]; khi nhiếm khuẩn cơ thể sẽ huy động kễm tham gia vào quá trình miễn dịch. Kết quả nghiên cứu của chúng tôi cho thây có mối liên quan nghịch chiều giữa tình trạng sốt với với tình trạng thiếu kẽm; có thể lý giải khi sốt, có thể sẽ huy động kẽm tham gia vào phản ứng chống viêm, làm nồng độ kẽm trong huyết thanh tăng lên. Mối liên quan thuận chiều giữa học vấn của ĐTNC với tình trạng thiếu kẽm được cho rằng trình độ học vấn thấp sẽ ảnh hưởng đến điều kiện kinh tể, cũng như kiến thức thực hành dinh dưỡng, dẫn đến chất lượng bữa ăn của đối tượng không đảm bảo.

Trong nghiên cứu này cho thấy có liên quan nghịch chiều giữa thiếu kẽm và phần trăm mỡ cơ thể, tình trạng CED, có thể được lý giải bởi chức năng của mô mõ được coi là một cơ quan nội tiết và sự dư thừa của nó làm tổn hại đến phản ứng miễn dịch và sự chuyển hóa của các hormone và chất dinh dưỡng [7]. Sự tích tụ chất béo nội tạng góp phần làm tăng tổng hợp cortisol, do đó gây ra biểu hiện metallothionein và Zip14, là những protein góp phần làm giảm nồng độ kẽm trong huyết tương [7]. Một số nghiên cứu trên thế giới đã cho thây mối liên quan giữa thừa cân, béo phì với nồng độ kẽm huyết thanh thấp (Canatan $\mathrm{H}$, 2004).

Tình trạng kẽm ảnh hưởng đến quá trình chuyển hóa vitamin $A$, bao gồm cả sự hấp thụ, vận chuyển và sử dụng nó [8]. Hai cơ chế thông thường giải thích sự phụ thuộc này liên quan đến 1) vai trò điều tiết của kẽm trong vận chuyển vitamin $\mathrm{A}$ qua trung gian tổng hợp protein, và 2 ) sự chuyển đổi oxy hóa của retinol thành retinal đòi hỏi hoạt động của enzyme retinol dehydrogenase phụ thuộc vào kẽm điều đó đã lý giải tương quan tuyến tính của kẽm với hàm lượng vitamin $A$ huyết thanh và mối liên quan giứa tình trạng thiếu kẽm với tình trạng thiếu vitamin $A$ ở kết quả nghiên của chúng tồi. Từ kết quả trên cho thấy, để cải thiện tình trạng thiếu kẽm, cần cải thiện tình trạng thiếu vi chất dinh dưỡng đặc biệt là tình trạng thiếu máu và thiếu vitamin $A$; ngoài các can thiệp phòng chống thiếu vi chất dinh dưỡng như các giải pháp giáo dục truyền thông, nâng cao chất lượng bữa ăn, cần bổ sung kẽm bằng nhiêu giải pháp (như bố sung kẽm định kỳ đường uống hay tăng cường sử dụng thực phẩm bổ sung kẽm, vitamin $A$ và sắt) để đảm bảo tính bền vững trong cải thiện tình trạng thiếu kẽm.

\section{KẾT LUẬN}

Tỷ lệ thiếu kẽm ở ĐTNC là 86,8\%, rất cao là vấn đề có YNSKCĐ. Nồng độ kẽm huyết thanh trung bình là $9,56 \pm 1,5 \mu \mathrm{mol} / \mathrm{L}$. Tỷ lệ thiếu kẽm ở nhóm 15 - 24 là $84,0 \%$ thấp hơn có YNTK so với nhóm $25-35$ tuổi $(89,1 \%)$. Có tương quan thuận chiều giữa nồng độ hemoglobin và retinol huyết thanh với nồng độ kẽm huyết thanh. Có liên quan giữa tình trang $C E D$, tình trạng sốt và tình trạng vitamin A đối với tình trạng thiếu kẽm.

\section{TÀI LIẸU THAM KHẢO}

1. Wessells KR, Brown KH. Estimating the global prevalence of zinc deficiency: results based on zinc availability in national food supplies and the prevalence of stunting. PLoS One, 2012; 7(11).

2. Engle-Stone R, Ndjebayi AO. Stunting prevalence, plasma zinc concentrations, and dietary zinc intakes in a nationally representative sample suggest a high risk of zinc deficiency among women and young children in Cameroon. The Journal of Nutrition. 2014; 144(3): 382-91.

3. Laillou A, Pham TV et al. Micronutrient deficits are still public health issues among women and young children in Vietnam. PLoS One 2012; 7, e34906

4. Viện Dinh dưỡng. Đánh giá tình trạng thiếu máu, thiếu một số vi chất dinh dưỡng của phụ nữ và tré em 6 - 59 tháng tại vùng thành thị, nông thôn và miên núi năm 2014 - 2015. Báo cáo đề tài nghiên cứu cấp Viện 2015.

5. Viện Dinh dưỡng. Báo cáo sơ bộ kết quả Tổng điểu tra Dinh dưỡng toàn quốc 2019 - 2020. 2021.

6. Read SA, Obeid S. The Role of Zinc in Antiviral Immunity. Adv Nutr, 2019. 10(4): 696-710.

7. Morais JBS, Severo JS et al. Association between Cortisol, Insulin resistance and Zinc in obesity: a Mini-Review. Biological Trace Element Research, 2019. 191: 323-330.

8. Christian P, West KPJ, Interactions between zinc and vitamin A: an update. Am J Clin Nutr, 1998. 68: p. 435S-441S. 


\title{
HIỆU QUẢ CAN THIÊPP BỔ SUNG VITAMIN D CẢI THIỆN TỶ LỂ NHIỂM KHUẨN HỐ HẤP Ở TRẺ DƯớI 5 TUỔI TẠI AN LÃO, HẢI PHÒNG NĂM 2017
}

\author{
Nguyễn Thị Ngọc Yến*, Vũ Thị Thủy*, Đinh Văn Thức**
}

\section{TÓM TẮT}

Mục tiêu. Nghiên cứu nhằm đánh giá hiệu quả cải thiện nồng độ vitamin $D$ và tỷ lệ nhiễm khuẩn hô hấp cấp bằng bổ sung vitamin $\mathrm{D}$ liểu 500 IU hàng ngày trong thời gian 1 năm. Đối tượng và phương pháp. Đối tượng gồm 164 trẻ chia thành 2 nhóm can thiệp và nhóm chứng mỗi nhóm 82 đối tượng. Phương pháp nghiên cứu can thiệp cộng đồng, đánh giá trước sau có đối chứng. Kết quả và kết luận. Sau can thiêp nồng độ vitamin $D$ trung bình của nhóm can thiệp tăng thêm $5,54 \mathrm{ng} / \mathrm{ml}$ so với của nhóm chứng là $1,38 \mathrm{ng} / \mathrm{ml}$, nồng độ vitamin $\mathrm{D}$ trung bình tăng thêm là $4,16 \mathrm{ng} / \mathrm{ml}$. Can thiệp vitamin $\mathrm{D}$ đã làm giảm tỷ lệ nhiễm khuẩn hô hấp ở nhóm can thiệp được 37,2\% so với nhóm chứng là $20,7 \%$, tỷ lệ nhiểm khuẩn hô hấp của nhóm can thiệp giảm hơn nhóm chứng là $22,7 \%$.

Tứ khóa. Nghiên cứu can thiệp, hiệu quả, vitamin D, nhiễm khuẩn hô hấp.

\section{SUMMARY}

THE EFFICACY OF VITAMIN D SUPPLEMENTATION FOR CHILDREN UNDER 5 TO IMPROVE THE INCIDENCE OF ACUTE RESPIRATORY INFECTION IN AN LAO, HAI PHONG IN 2017

Objective. The study was carried out to evaluate the efficacy of 500 IU vitamin D supplementation daily for children under 5 to improve the the incidence of acute respiratory infection in An Lao, Hai Phong in 2017 during one year. Subjects and Methods. Subjects included 164 under 5 children divided into 2 groups: intervention and control group. Method was a community intervention controlled trial, compared before and after the entervention. Results and conclusions. After the intervention, mean vitamin D of intervention group increased $5.54 \mathrm{ng} / \mathrm{ml}$ higher than that of control group $1.38 \mathrm{ng} / \mathrm{ml}$, mean vitamin D difference between group was $4.16 \mathrm{ng} / \mathrm{ml}$. Vitamin D supplementation reduced $37.4 \%$ in the intervention group and $14.7 \%$ in the control group, and incidence difference between 2 groups was $22,7 \%$.

Keywords. Intervention study, efficacy, vitmain $D$, acute respiration infection.

\section{I. ĐĂT VẤN ĐỀ}

Từ năm 1983 TCYTTG đã xây dựng chương

*Bệnh viện Trẻ em Hải Phòng

**Trường Đai hoc Y Dước Hải Phòng

Chịu trách nhiệm chính: Nguyễn Thị Ngọc Yến

Email: bsyenbvte@gmail.com

Ngày nhận bài: 22.6.2021

Ngày phản biên khoa hoc: 17.8.2021

Ngày duyệt bài: 23.8.2021 trình phòng chống nhiễm khuẩn hô hấp cấp tính (chương trình ARI), áp dụng ở Việt Nam vào năm 1984 đã là làm tỷ lệ mắc và tử vong đáng kể bệnh này tuy nhiên NKHHC vẫn là bệnh có tỷ lệ mắc và tử vong cao ở lứa tuổi này[2]. Indonesia, Ấn Độ, Nigeria, Pakistan và Trung Quốc đã chiếm 54\% trong số 138 triệu viêm phổi trên toàn câu vào năm 2015 [4]. Theo Adebola E. Orimadegun và CS [3], có 1.071 triệu trẻ 1-59 tháng ở châu Phi chết vì viêm phổi, chiếm 14,1\% tử vong do tất cả các nguyên nhân.

Từ năm 2007, sau khi Holick FM [9] công bố dịch thiếu hụt vitamin $D$ và vai trò của nó trong nhiều bệnh nhất là trong việc cải thiện tỷ lệ bệnh nhiễm khuẩn hô hấp cấp đã có nhiều nghiển cứu can thiệp được tiến hành. Tuy nhiên theo Giuseppe Saggesse và CS [5] trong đông thuận của Hội Nhi khoa Italia năm 2018 cho thấy qua nghiên cứu gộp các thử nghiệm lâm sàng, nghiên cứu quan sát trên thế giới còn có các ý kiến trái chiêu nhau. Cũng theo Giustina $A$ và $C S$ [6] về đồng thuận Quốc tế lần thứ 2 về những những vấn đề còn chưa thống nhất về vitamin $D$. Theo các đồng thuận này thì tác dụng của vitamin $D$ làm giảm tỷ lệ mắc $N K H H C$ và làm giảm mức độ nặng của các bệnh NKHHC ở trẻ dưới 5 tuổi còn chưa rõ ràng, cần có nghiên cứu nhiều hơn nữa để có kết luận cụ thể.

Từ thực tế này chúng tôi tiến hành đề tài nhằm mục tiêu sau đây: Đánh giá hiệu quả bổ sung vitamin $D$ với nhiểm khuân hô hấp câp tính trẻ dưới 5 tuôii tại huyện An Lão, Hải Phòng năm 2017.

\section{II. ĐỐI TƯỢNG VÀ PHƯƠNG PHÁP NGHIÊN CỨU}

2.1. Đối tượng, địa điểm và thời gian nghiên cứu:

- Gồm 164 trẻ dưới 5 tuổi được chia thành 2 nhóm can thiệp (NCT) và nhóm chứng (NC). Nhóm can thiệp là xã Trường Thọ và nhóm chứng là xã An Thắng.

Đây là những đối tượng đã tham gia nghiên cứu ở giai đoạn 1 .

Tiêu chuẩn lựa chọn: bệnh nhân đồng ý tham gia nghiên cứu, cam kết không uống bất cứ chế phẩm vitamin $D$ nào khác ngoài chế phẩm do nghiên cứu cung cấp.

Nghiên cứu tại 2 xã của huyện An Lão, Hải 
Phòng. Thời gian từ 12/2016 đến 12/2017.

\subsection{Phương pháp nghiên cứu}

2.2.1. Thiết kế nghiên cứu: Nghiên cứu can thiệp cộng đồng, so sánh trước sau có đối chứng.

\subsubsection{Cõ̃ mẫu/chọn mẫu}

Chúng tôi sử dụng công thức tính cỡ mẫu dựa trên đánh giá sự thay đổi nồng độ Vitamin $D$ sau can thiệp cho NCT và NC: cụ thể tính ra cỡ mẫu 82 trẻ cho 1 nhóm. Số trẻ ở mỗi nhóm được chọn theo phương pháp ngẫu nhiên hệ thống trên cơ sở những trẻ đang tham gia nghiên cứu ở điều tra ngang.

Bảng 2.1. Danh sách trẻ $0-<5$ tuổi của các xã được chọn vào nghiên cứu giai đoạn 2.

\begin{tabular}{|c|c|c|}
\hline$T \pi$ & Tên xã & Số trẻ 0-<5 tuối \\
\hline 1 & $\begin{array}{l}\text { Trường Tho } \\
\text { (NCT) }\end{array}$ & $\begin{array}{l}207 \text { (7 loại vì nồng độ } \\
\text { vitamin } \mathrm{D}<20 \mathrm{ng} / \mathrm{ml} \text { ) }\end{array}$ \\
\hline 2 & $\begin{array}{l}\text { An Thắng } \\
\text { (NC) }\end{array}$ & $\begin{array}{l}190 \text { (2 loại vì nồng đố } \\
\text { vitamin } \mathrm{D}<20 \mathrm{ng} / \mathrm{ml} \text { ) }\end{array}$ \\
\hline Tống & & 397 \\
\hline
\end{tabular}

Chúng tôi loại khỏi nghiên cứu 9 trẻ có nồng độ vitamin $D$ thấp $<20 \mathrm{ng} / \mathrm{ml}$ để điều trị thiếu vitamin $\mathrm{D}$ (xem bảng 2.1 ).

2.2.3. Tiến hành can thiệp

Nhóm can thiệp: Tất cả đối tượng được uống hàng ngày 1 giọt vitamin $D$ tương đương 500 IU có tên là Aquadertrim có bán trên thị trường Việt Nam. Thời gian uống 1 năm. Thời điểm bắt đầu uống sau điều tra ngang (T0). Trong quá trình uống vào tháng thứ 6 (T6) và tháng thứ (T12) là tháng kết thúc can thiệp trẻ đều được xét nghiệm nồng độ vitamin $D$, cân, đo, khám phát hiện bệnh nhiễm khuẩn hô hấp.

Nhóm chứng: Trẻ không được tác động gì, nhưng vẫn được theo dõi theo các thời điểm và làm các đánh giá giống nhóm can thiệp. Trẻ vẫn được hưởng các chương trình dành cho trẻ dưới 5 tuổi tại địa phương.

\subsubsection{Chỉ số và biến số}

- Tuổi, giới

- Chiều cao, cân nặng

- Nồng độ vitamin D

- Hiêuu quả cải thiện nồng độ vitamin D câp

- Hiệu quả cải thiện tỷ lệ nhiễm khuẩn hô hấp

2.2.5. Thu thập thông tin.Sau can thiệp vào tháng 12/2017, các thông tin cần thu thập gồm:

- Cân nặng, chiều cao, nồng độ vitamin D và tỷ lệ nhiễm khuẩn hô hấp cấp.

- Công cụ, trang thiết bị và điều tra viên giống như ở nghiên cứu ngang.

2.2.6. Xử lý số liệu

Số liệu thu được, được làm sạch và nhập vào phần mềm SPSS 20.0.

Tính giá trị trung bình, so sánh giá trị trung bình bằng paired samgples $T$ test, sự khác biệt có ý nghĩa khi $p<0,05$. Dùng $x^{2}$ test để so sánh 2 số \%, có sự khác biệt khi $p<0,05$.

\section{KẾT QUẢ NGHIÊN CỨU}

3.1. Thông tin về đối tượng tham gia nghiên cứu can thiệp

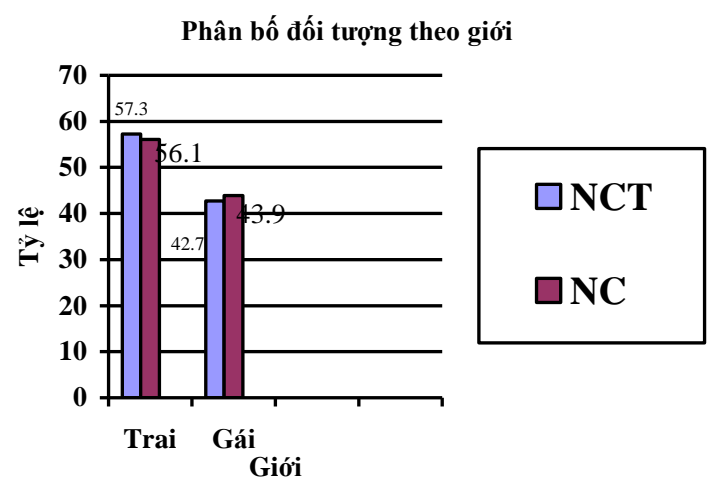

Hình 3.1. Phân bố đôi tượng can thiệp theo giới và theo địa điểm nghiên cứu $(n 1=n 2=82)$

Nhận xét. Ở xã can thiệp, trẻ trai nhiều hơn trẻ gái và ở xã chứng trẻ trẻ gái nhiều hơn trẻ trai, tuy nhiên sự khác nhau không có ý nghĩa thống kê với $p=0,875$.

Bảng 3.1. Phân bố đôi tượng can thiệp theo nhóm tuổi và theo xã

\begin{tabular}{|c|c|c|c|c|}
\hline $\begin{array}{c}\text { Nhóm } \\
\text { tuối } \\
\text { (tháng) }\end{array}$ & $\begin{array}{c}\text { NCT } \\
(\mathbf{n 1 , \% )}\end{array}$ & $\begin{array}{c}\text { NC } \\
(\mathbf{n 2} \mathbf{2} \%)\end{array}$ & Tổng & \multirow{2}{*}{$\mathbf{p}$} \\
\hline $0-<12$ & $3(42,9)$ & $4(57,1)$ & $7(4,3)$ & \\
\hline $12-<24$ & $12(35,5)$ & $22(64,7)$ & $34(20,7)$ & \\
\hline $24-<36$ & $23(53,5)$ & $20(46,5)$ & $43(26,2)$ & 0,35 \\
\hline $36-<48$ & $24(54,2)$ & $22(45,8)$ & $46(28,0)$ & \\
\hline $48-<60$ & $20(58,8)$ & $14(41,2)$ & $34(20,7)$ & \\
\hline Tống sốn & $\mathbf{8 2}$ & $\mathbf{8 2}$ & $\mathbf{1 6 4}$ & \\
\hline
\end{tabular}

Nhận xét. Nhìn cả 2 xã can thiệp và chứng chúng tôi thấy đối tượng tham gia nghiên cứu tập trung vào nhóm tuổi $12-<24$ đến $48-<60$ tháng với tỷ lệ lần lượt là $20,7 \%, 26,2 \%, 28,0 \%$ và $20,7 \%$. Nhóm $0-<12$ tháng chiếm tỷ lệ thấp nhất 4,3\%.

So nhóm tuổi theo xã can thiệp và xã chứng chúng tôi thây xã chứng có nhóm đối tượng 3,4 và 5 tuổi có số đối tượng nhiều hơn xã chứng nhưng ở nhóm 1 và 2 tuổi xã chứng lại có số đối tượng nhiều hơn xã can thiệp, nhưng khác biệt này không có ý nghĩa thống kê với $p=0,35$.

\subsection{Hiệu quả can thiệp bổ sung vitamin D}


VIETNAM MEDICAL JOURNAL N01 - SEPTEMBER - 2021

Bảng 3.2. Hiệu quả cải thiện nồng độ vitamin $D(\mathrm{ng} / \mathrm{ml}$ của nhóm can thiệp và nhóm chứng (n1=n2=82)

\begin{tabular}{|c|c|c|c|c|c|}
\hline Địa điểm & $\begin{array}{c}\text { Vitamin TB } \\
\text { ơ TO }\end{array}$ & $\begin{array}{c}\text { Vitamin D TB } \\
\text { ơ T6 }\end{array}$ & $\begin{array}{c}\text { Vitamin D TB ở } \\
\text { T12 }\end{array}$ & & $\mathbf{p}$ \\
\hline & $26,65 \pm 4,63^{*}$ & $30,88 \pm 8,59 * *$ & $32,19 \pm 4,72^{* * *}$ & & \\
\hline \multirow[t]{2}{*}{ NCT } & & $\begin{array}{c}\text { Vitamin D TB tăng } \\
\text { thêm (T0-6) }\end{array}$ & $\begin{array}{c}\text { Vitamin D TB tăng } \\
\text { thêm (T6-12) } \\
\end{array}$ & $\begin{array}{l}\text { Vitamin D TB tăng } \\
\text { thêm (T0-12) }\end{array}$ & \multirow{2}{*}{$\begin{aligned}(0,6) & =0,000 \\
(6-12) & =0,000 \\
(0,12) & =0,000\end{aligned}$} \\
\hline & & $4,23 \pm 3,96^{1}$ & $1,30 \pm 3,87^{2}$ & $5,54 \pm 0,09^{3}$ & \\
\hline Địa điếm & Vitamin TB ở T0 & \begin{tabular}{|l} 
Vitamin D TB ở T6 \\
\end{tabular} & Vitamin D TB ơ T12 & & $p$ \\
\hline \multirow{3}{*}{ NC } & $27,15 \pm 5,84^{*}$ & $26,88 \pm 6,37^{* *}$ & $28,71 \pm 6,94 * * *$ & & \multirow{3}{*}{$\begin{aligned}(0,6) & =0,77 \\
(6-12) & =0,121 \\
(0,12) & =0,100\end{aligned}$} \\
\hline & & $\begin{array}{c}\text { Vitamin D TB tăng } \\
\text { thêm }(T 0-6)\end{array}$ & \begin{tabular}{|c} 
Vitamin D TB tăng \\
thêm (T6-12)
\end{tabular} & $\begin{array}{l}\text { Vitamin D TB tăng } \\
\text { thêm (T0-12) }\end{array}$ & \\
\hline & & $0,27 \pm 0,17^{1}$ & $1,55 \pm 1,10^{2}$ & $1,38 \pm 1,16^{3}$ & \\
\hline $\mathrm{p}$ & $* 0,544$ & $* * 0,001$ & $* * * 0,000$ & & \\
\hline $\begin{array}{l}\text { Mức chênh } \\
\text { nhau }\end{array}$ & & $3,96 \pm 3,79^{1}$ & $0,25 \pm 2,77^{2}$ & $4,16 \pm 1,07^{3}$ & \\
\hline
\end{tabular}

Paired samples T-Test được sử dụng để so sánh nồng độ vitamin D TB của NCT và NC trước và sau can thiệp

*nồng độ vitamin D TB ở To; **nồng độ vitamin D TB ở T6; ***nồng độ vitamin D TB ở T12; 1 , 2,3nồng độ vitamin D TB chênh nhau ở NCT và NC theo thời điểm T0, 6 và 12 .

Nhận xét. Ở nhóm can thiệp, nồng độ vitamin D TB tăng từ $26,65 \pm 4,63 \mathrm{ng} / \mathrm{ml}$ lên $30,88 \pm 8,59 \mathrm{ng} / \mathrm{ml}$ tháng thứ 6 và $32,19 \pm 4,72$ $\mathrm{ng} / \mathrm{ml}$ ở T12. Sự khác biệt về nồng độ trung bình ở các thời điểm sau can thiệp có ý nghĩa thống kê với $p$ đều là 0,000 . Nồng độ vitamin $D$ TB tăng thêm từ 4,23 lên 5,54 ng/ml.

Ơ nhóm chứng nồng độ vitamin D TB tăng từ $27,15 \pm 5,84 \mathrm{ng} / \mathrm{ml}$ lên $26,88 \pm 6,37 \mathrm{ng} / \mathrm{ml}$ tháng 6 và $28,71 \pm 6,94 \mathrm{ng} / \mathrm{ml}$ tháng 12 những sự tăng này chưa đủ lớn tạo ra sự khác biệt với $\mathrm{p}$ lần lượt là $0,77,0,121$ và 0,100 . Nồng độ vitamin $D$ TB tăng thêm tăng từ 0,27 lên $1,38 \mathrm{ng} / \mathrm{ml}$ ở tháng 12. Có sự khác biệt lớn về tăng nồng độ vitamin D TB ở 2 xã vào tháng $6(30,88 \pm 8,59$ $\mathrm{ng} / \mathrm{ml}$ và $26,88 \pm 6,37 \mathrm{ng} / \mathrm{ml}, \mathrm{p}=0,001)$ và tháng thứ 12 là $32,19 \pm 4,72 \mathrm{ng} / \mathrm{ml}$ và $28,71 \pm 6,94$ $\mathrm{ng} / \mathrm{ml}$ và $\mathrm{p}=0,000$.

Nồng độ vitamin $\mathrm{D}$ cải thiện tốt hơn ở nhóm can thiệp vào tháng thứ 6 và 12 , trong khi đó không cải thiện ở nhóm chứng.

\subsection{Hiệu quả cải thiện tỷ lệ nhiễm khuẩn hô hấp}

Bảng 3.3. Hiệu quả cải thiện tỷ lệ nhiếm khuấn hô hấp ở xã can thiệp và xã chứng sau can thiệp $(n 1=n 2=82)$

\begin{tabular}{|c|c|c|c|c|c|}
\hline $\begin{array}{l}\text { Đia } \\
\text { điểm }\end{array}$ & $\begin{array}{l}\text { Tỷ lệ NKHH } \\
\text { ờ To }(n, \%)\end{array}$ & $\begin{array}{l}\text { Tỷ lệ NKHH } \\
\text { ở T6́ }(n, \%)\end{array}$ & $\begin{array}{l}\text { Tỷ lệ NKHH } \\
\text { ở T12 (n,\%) }\end{array}$ & & p \\
\hline \multirow{3}{*}{ NCT } & $35^{*} 47,2$ & $25 * * 30,5$ & $8 * * * \quad 9,8$ & & \multirow{3}{*}{$\begin{aligned}(0,6) & =0,105 \\
(6-12) & =0,0009 \\
(0,12) & =0,0002\end{aligned}$} \\
\hline & & $\begin{array}{c}\text { Tỷ lê NKHH giảm đi } \\
(\mathrm{T} 0-6)(\%)\end{array}$ & $\begin{array}{c}\text { Tỷ lệ NKHH giảm đi } \\
(\text { T6-12)(\%) }\end{array}$ & $\begin{array}{l}\text { Tỷ lê NKHH giảm } \\
\text { đi }(T 0-12)(\%)\end{array}$ & \\
\hline & & $12,2^{1}$ & $20,7^{2}$ & $37,4^{3}$ & \\
\hline Địa điểm & $\begin{array}{l}\text { Tỷ lê NKHH } \\
\text { ở Tó }(n, \%)\end{array}$ & $\begin{array}{l}\text { Tỷ lề NKHH } \\
\text { ớ T6́ }(n, \%)\end{array}$ & $\begin{array}{c}\text { Tỷ lệ NKHH ở T12 } \\
(n, \%)\end{array}$ & & $\mathrm{p}$ \\
\hline \multirow{3}{*}{ NC } & $29 * 35,4$ & $24 * * 29,3$ & $17 * * * \quad 20,7$ & & \multirow{3}{*}{$\begin{array}{c}(0,6)=0,403 \\
(6-12)=0,860 \\
(0,12)=0,086\end{array}$} \\
\hline & & $\begin{array}{l}\text { Tỷ lệ NKHH giảm đi } \\
(T 0-6)(\%)\end{array}$ & $\begin{array}{c}\text { Tỷ lệ NKHH giám đi } \\
\text { (T6-12) (\%) }\end{array}$ & $\begin{array}{l}\text { Tỷ lê NKHH giảm } \\
\text { đi (T0-12) (\%) }\end{array}$ & \\
\hline & & $6,1^{1}$ & $8,6^{2}$ & $14,7^{3}$ & \\
\hline$p$ & $* 0,337$ & $* * 0,864$ & $* * * 0,0206$ & & \\
\hline $\begin{array}{l}\text { Mức } \\
\text { chênh }\end{array}$ & & $6,1^{1}$ & $12,1^{2}$ & $22,7^{3}$ & \\
\hline
\end{tabular}

Chi square sử dụng để so sánh 2 tỷ lệ, sự khác biệt khi $p<0,05$.

*tỷ lệ NKHH ở To; **tỷ lệ NKHH ở T6; ***tỷ lệ NKHH ở T12; 1, 2,3tỷ lệ NKHH chênh nhau ở NCT và NC theo thời điểm T0, 6 và 12 .

Nhận xét. Ở nhóm can thiệp tỷ lệ nhiễm

khuẩn hô hấp giảm từ T0 đến T6 không có ý nghĩa thống kê với $p=0,105$, từ T6 đến T12 có ý nghĩa thống kê với $p=0,0009$, tỷ lệ nhiễm khuẩn hô hấp cấp giảm từ T0 đến T12 là 37,4\% và sự khác biệt có ý nghĩa thống kê với $p=0,0002$.

ở nhóm chứng tỷ lệ nhiễm khuẩn hô hấp cấp 
giảm không rõ rệt, sự khác biệt này đều không có ý nghĩa thông kê với $p$ lần lượt là $0,403,0,86$ và 0,086 .

Tỷ lệ nhiễm khuẩn hô hấp ở T0 không có sự khác nhau giữa 2 xã $(p=0,337)$, ở T6 $p=864$ nhưng ở T12 tỷ lệ NKHH ở nhóm can thiệp thấp hơn rất nhiều so với nhóm chứng và $p=0,0206$.

\section{BÀN LUẬN}

4.1. Hiệu quả cải thiện nông độ vitamin. Bảng 3.2 cho thấy sau hiệu quả can thiệp nâng nồng độ vitamin D TB của NCT và NC. Ở NCT nồng độ vitamin $\mathrm{D}$ TB trước can thiệp (T0) là $26,65 \pm 4,63 \mathrm{ng} / \mathrm{ml}$ tăng lên $30,88 \pm 8,59 \mathrm{ng} / \mathrm{ml}$ (T6) và $32,19 \pm 4,72 \mathrm{ng} / \mathrm{ml}$ ở T12. Sự khác biệt về nồng độ ở các thời điểm sau can thiệp so với trước can thiệp đều có ý nghĩa thống kê:: $p(0,6)$, $\mathrm{p}(6-12), \mathrm{p}(0,12)$ đều là 0,000 . Tính mức tăng nồng độ vitamin $B$ TB ở $T(0-6)$ là 4,23 $\pm 3,96$ $\mathrm{ng} / \mathrm{ml}$, ở $\mathrm{T}(6-12)$ là $1,30 \pm 3,87 \mathrm{ng} / \mathrm{ml}$ và ở $\mathrm{T}(0-$ 12) là $5,54 \pm 0,09 \mathrm{ng} / \mathrm{ml}$.

Ớ NC, nồng độ vitamin D TB trước can thiệp là $27,15 \pm 5,84 \mathrm{ng} / \mathrm{ml}$, ở T6 nồng độ vitamin $D$ TB là $26,88 \pm 6,37 \mathrm{ng} / \mathrm{ml}$ và ở $\mathrm{T} 12$ nồng độ vitamin D TB là $28,71 \pm 6,94 \mathrm{ng} / \mathrm{ml}$. Mức tăng nồng độ vitamin $D$ TB thời điểm $T(0,6)$ là $0,27 \pm$ $0,17 \mathrm{ng} / \mathrm{ml}$, thời điểm $\mathrm{T}(6-12)$ là $1,55 \pm$ $1,10 \mathrm{ng} / \mathrm{ml}$ và thời điểm $\mathrm{T}(0,12)$ là $1,38 \mathrm{ng} / \mathrm{ml}$.

Khi so sánh nồng độ vitamin D TB ở T0, T6 và T12 chúng tôi thây chỉ nồng độ vitamin $D$ TB của NCT và NC ở T6 và T12 có sự khác nhau với $p$ lân lượt là 0,001 và 0,000 . Ở $T 12$ nồng độ vitamin $D$ TB của NCT cao nhiêuu hơn NC là 4,16ng/ml.

Theo Nguyễn Xuân Hùng [1] tỷ lệ thiếu hụt Vitamin D ở NCT là 20,7\%, sự khác biệt tỷ lệ trước can thiệp $(38,9 \%)$ và sau can thiệp $(18,2 \%)$ có ý nghĩa thống kê. Hiệu quả can thiệp đạt $53,21 \%(p<0,05)$. Sự cải thiện không đáng kể về tỷ lệ thiếu hụt Vitamin $D$ ở NC trước - sau can thiệp ( $46,4 \%$ so với $44,2 \%$ theo thứ tự và $\mathrm{p}>0,05)$. So sánh tỷ lệ thiếu hụt Vitamin $D$ trước can thiệp của 2 nhóm tác giả không thây có sự khác biệt $p>0,05(0,368)$ nhưng so sánh tỷ lệ thiếu hụt sau can thiệp của 2 nhóm có sự khác biệt $(18,2 \%$ ở NCT và $44,2 \%$ ở nhóm NC và $p<0,01)$.

Tác giả Heike $A$ Bischoff Ferrari và CS năm 2006 bổ sung một liều cho tất cả người lớn $>1000$ IU Vitamin D ngày để có thể đạt được trên $50 \%$ dân số có nồng độ Vitamin $D$ trên 75 nmol/L [7]. Nghiên cứu của Steven Abrams năm 2013 đã lựa chọn liều bổ sung 1000 IU Vitamin D ngày cho mọi nhóm tuổi, sau 8 tuần bổ sung Vitamin $D$ đã tìm thây mối quan hệ có ý nghĩa giữa nồng độ $1,25(\mathrm{OH})_{2}$ Vitamin $\mathrm{D}$ và hấp thu canxi. Theo tác giả Holick và CS nghiên cứu năm 2008, chỉ khi liều Vitamin D được tăng lên đến 800 IUngày trong 5 tháng thì nồng độ 25 $(\mathrm{OH})_{2}$ VitaminD mới tăng lên và duy trì trên 75 $\mathrm{nmol} / \mathrm{L}$ hay $30 \mathrm{ng} / \mathrm{mL}$ [8]. Nghiên cứu của chúng tôi áp dụng với liều bố sung 200.000 IU trong 12 tháng đã cải thiện tỷ lệ thiếu hụt Vitamin $D$ ở 68,64\% đối tượng can thiệp.

4.2. Hiệu quả cải thiện tỷ lệ nhiễm khuẩn hô hấp. Bảng 3.3 cho thấy hiệu quả cải thiện bệnh NKHH sau can thiệp ở NCT và NC. Ở NCT, chúng tôi thây tỷ lệ NKHH trước can thiệp TO là $47,2 \%$, giảm xuống $30,5 \%$ ở $\mathrm{T} 6$ và $9,8 \%$ ở $\mathrm{T} 12$. Tỳ lệ giảm từ T0-6 là 12,2\% tuy nhiên sự khác biệt này không có ý nghĩa thống kê $(p=0,105)$. Tỷ lệ giảm $T(6,12)$ là $20,7 \%$ và sự khác biệt này có ý nghĩa thống kê với $p=0,000$. Tỷ lệ NKHH giảm $\mathrm{T}(0-12)$ là $37,4 \%$ và tất nhiên sự khác biệt này rất có ý nghĩa thống kê với $p=0,000$.

Ở nhóm chứng, tỷ lệ NKHH giảm từ 35,4\% ở T0 xuống 29,3\% T6 nhưng sự khác biệt không có ý nghĩa thống kê $(p=0,403)$, từ $29,5 \%$ ở T6 xuống 20,7\% ở T12 nhưng sự khác biệt cũng không có ý nghĩa thống kê $(p=0,860)$. Từ T0 xuống T12 tỷ lệ NKHH giảm chưa đủ mạnh để có sự khác biệt với $p=0,086$.

Theo chiều ngang tỷ lệ NKHH ở thời điểm TO, T6 của NCT và NC cũng không có sự khác biệt $p$ lần lượt là $0,337,0,864$. Tuy nhiên ở thời điểm T12, tỷ lệ NKHH ở NCT giảm nhiều hơn NC và sự khác biệt về tỷ lệ này có ý nghĩa thống kê với $\mathrm{p}=0,0206$. Đến T12 tỷ lệ NKHH của NCT giảm hơn NC là 22,7\%.

Kết quả nghiên cứu của chúng tôi phù hợp với các nghiên cứu trong và ngoài nước. Trước hết kết quả thử nghiệm ngẫu nhiên có đối chứng cho thây hiệu quả bổ sung vitamin $D$ làm giảm các bệnh NKHH. Nghiên cứu của Mark Loeb và CS ở trẻ em và thiếu niên Việt Nam bổ sung 14.000 đơn vị vitamin $\mathrm{D}$ hàng tuần trong 8 cho 650 trẻ 3-17 tuổi và bổ sung giả dược cho 650 trẻ khác cùng tuổi, trong cùng thời gian cho thây hiệu quả giảm nhiễm khuẩn không do siêu vi khuẩn ở nhóm bổ sung vitamin $D$ rất rõ ràng với HR là 0,81 .

Thử nghiệm ngẫu nhiên đối chứng mù kép của Semira Manaseki-Holland và CS để xác định việc bổ sung 100.000 đơn vị vitamin $D D_{3}$ kết hợp với kháng sinh có làm giảm thời gian bệnh của trẻ mắc viêm phổi và giảm nguy cơ tái phát bệnh. Nhóm bổ sung vitamin $D$ gồm 224 trẻ 1-36 tháng, nhóm giả dược gồm 229 trẻ. Kết quả cho thấy bổ sung vitamin $D$ làm giảm tái phát bệnh trong vòng 90 ngày sau bổ sung $(\mathrm{HR}=0,71)$. 
Nghiên cứu thử nghiệm đối chứng mù kép khác của Seiji Arihiro và CS trên 223 trẻ mắc bệnh đường ruột được chia thành 2 nhóm, nhóm bổ sung vitamin $D$ và nhóm bổ sung giả dược ( $n=108$ và $n=105$ theo thứ tự). Đối tượng nhận 500 đơn vị vitamin $D$ hàng ngày. Kết quả cho thấy nhóm bổ sung vitamin $\mathrm{D}$ có tỷ lệ mắc $\mathrm{NKHH}$ trên thấp hơn nhiều nhóm dùng giả dược ( $R R=0,59)$.

Rashmi Ranjan Das và CS nghiên cứu gộp 32 nghiên cứu để so sánh điều trị viêm phổi bằng vitamin $D$ và giả dược. Liều vitamin $D$ được sử dụng từ 1000 đơn vị đến 100.000 đơn vị cho trẻ dưới 5 tuổi, cách thức cung cấp vitamin $D$ có thể là liều đơn, hay 5 liều trong vòng 5 ngày, thời gian can thiệp là 1 năm. Kết quả không như trông đợi, việc sử dụng vitamin $D$ đường uống này không giúp nhiều cho trẻ dưới 5 tuổi mắc viêm phổi cấp.

\section{KẾT LUÂN}

Sau can thiệp nồng độ vitamin $D$ trung bình của nhóm can thiệp tăng thêm $5,54 \mathrm{ng} / \mathrm{ml}$ so với của $\mathrm{NC}$ là $1,38 \mathrm{ng} / \mathrm{ml}$, nồng độ vitamin $\mathrm{D}$ trung bình tăng thêm là $4,16 \mathrm{ng} / \mathrm{ml}$.

Can thiệp vitamin $D$ đã làm giảm tỷ lệ nhiễm khuẩn hô hấp ở nhóm can thiệp được 37,4\% so với nhóm chứng là $14,7 \%$, tỷ lệ nhiếm khuẩn hô hấp của nhóm can thiệp giảm hơn nhóm chứng là $22,7 \%$.

\section{TÀI LIỆ THAM KHẢO}

1. Nguyễn Xuân Hùng (2020), Thực trang suy dinh dưỡng thấp còi và hiệu quả can thiệp ở trẻ 12 đến
36 tháng tuổi tại huyện Kim Động, tỉnh Hưng Yên năm 2017", Luận án tiến sỹ Y học, Trường đại học Y Dược Hải Phòng.

2. Trân Quy. (2013), "Nhiễm khuẩn hô hấp cấp tính", Bài giảng nhi khoa tập 1 - Nhà xuất bản y học Hà Nội, trang 380-389.

3. Adebola E. Orimadegun et al (2020), "A systematic review and meta-analysis of sex defferences in morbidity and mortality of acute lower respiratory tract infections among african children", J Pediatr Rev, 8(2):65-78. doi:10.32598/jpr.8.2.65.

4. David A McAllister et al (2019), "Global, regional, and national estimates of pneumonia morbidity and mortality in children younger than 5 years between 2000 and 2015: a systematic analysis", Lancet Glob Health, 7(1):e47e57.doi:10.1016/S2214-109X(18)304408-X.

5. Giuseppe Saggesse et al (2018), "Vitamin D in pediatric age: consensus of the Italian Pediatric Society and the Italian Society of Preventive and social Pediatric, jointly with the Italian Federation of Pediatricians", Ital K Padiatr, 44:51. doi:10.1186/s13052-018-0488-7.

6. Giustina A và CS (2020), "Consensus statement from $2^{\text {nd }}$ International conference on controversies in vitamin D", Rev Endocr Metab Disord, 21(1):89116. doi: $10.1007 / \mathrm{s} 11154-019=09532-w$.

7. Heike A Bischoff - Ferrari et al (2006) "Estimation of optimal serum concentrations of 25 - hydroxyvitamin D for multiple health outcomes", Am J Clin Nutr. 84 (1): 18 - 28.

8. Holick F Michael (2007), "The vitamin D deficiency pandemic: Approach for diagnosis, treatment and prevention", Rev Endocr Metab Disord, 18(2):153-165. doi: $10.1007 / \mathrm{s} 11154-017$ 9424-1.

9. Holick MF and Tai C Chen (2008), "Vitamin D deficiency: a worldwide problem with health consequences", Am J Clin Nutr. 87 (4): 1080S - 1086S.

\section{NHÂN 1 TRƯờ'NG HỢP THAI NGOÀI Ý MUỒN TRONG KHI SỬ DỤNG QUE CẤY TRÁNH THAI IMPLANON NXT®}

\section{Nguyễn Ngọc Phương ${ }^{1}$, Hà Duy Tiến ${ }^{1}$, Nguyễn Thị Hồng Nhung ${ }^{1}$}

\section{TÓM TẮT}

Implanon $®$ là một nang chứa progestin tổng hợp (etonogestrel), được cấy dưới da với tác dụng tránh thai lâu dài có hồi phục. Trong hơn 10 năm có mặt tại thi trường Viêt Nam, Implanonß đang dân trở nên phổ biến vì tính tiện lợi và hiệu quả tránh thai rất cao. Các trường hợp mang thai ngoài ý muốn với que cây

${ }^{1}$ Bệnh viện Phụ Sản Trung Uơng

Chịu trách nhiệm chính: Nguyễn Ngọc Phương

Email: pika.hmu@gmail.com

Ngày nhận bài: 24.6.2021

Ngày phản biên khoa họ: 17.8.2021

Ngày duyệt bài: 25.8.2021 tránh thai etonogestrel là rất hiếm. Chúng tôi báo cáo 1 trường hợp có thai trong buồng tử cung trong khi đang tránh thai bằng que cấy Implanon NXTß. Bênh nhân 27 tuổi PARA 1001, cây que tránh thai từ tháng 4/2017. Sau cấy 8 tháng, bênh nhân được chẩn đoán lao phổi và điêu trị theo phác đồ 2RHZE/4RHE. 6 tháng sau khi bắt đâu điều trị, bệnh nhân phát hiện có thai 18 tuần. Que cấy vẫn nằm đúng vị trí và được tháo toàn ven sau đó 1 tuần. Bênh nhân tiếp tục theo dõi thai, đẻ thường đủ tháng với kết quả thăm khám sơ sinh bình thường. Qua đó minh họa như y văn đã đề cập, thuốc chống lao (với tác dụng cảm ứng enzym ở gan) có thể làm giảm tác dụng tránh thai của Implanon $\AA$.

Tư khóa: Thai ngoài ý muốn, que cấy tránh thai, Implanon, thuốc chống lao. 


\section{SUMMARY \\ UNINTENDED PREGNANCY WITH IMPLANTABLE SUBDERMAL CONTRACEPTIVE DEVICE IMPLANON: A CASE REPORT}

Implanon $\AA$, a synthetic subcutaneous progestin etonogestrel eluting capsule, was approved for use to provide long-acting reversible contraception (LARC). During more than 10 years of presence in Vietnam, Implanon $\AA$ becomes more and more popular because of its convenience and high birth control effect. The unintended pregnancy in patients using an etonogestrel contraceptive implant is very rare. We report 1 case of intrauterine pregnancy while using Implanon NXT\&. She is 27 years old, PARA 1001, contraceptive implanted since April 2017. After 8 months of implantation, she was diagnosed with pulmonary tuberculosis and treated according to the 2RHZE/4RHE regimen. 6 months after starting treatment, the patient was found to be 18 weeks pregnant. The implant remained in place and was removed intact 1 week later. The patient continued the pregnancy, delivered normally at full term with normal neonatal examination results. Thereby illustrating as mentioned in the literature, antitubercular medications (hepatic enzyme inducers) may reduce the contraceptive effect of Implanon $\AA$.

Keywords: unintended pregnancy, implantable subdermal contraceptive, Implanon, antitubercular medications.

\section{I. ĐĂT VẤN ĐỀ}

Có 4 loại progestin được sử dụng trong các biện pháp tránh thai bằng que cây bao gồm: levonorgestrel (Norplant ${ }^{\circledR}$, Jardelle $\AA$ ), nestorone (Elcometrine $®$ ), nomegestrol acetate (Uniplant $\AA$, Surplant $\AA$ ) và etonogestrel (Implanon $®$ ). Trong đó, Implanon $®$ (thế hêe mới là Implanon NXT $®$ hay Nexplanon $\circledR$ ) là loại que cấy mới nhất và được sử dung phổ biến nhất, chứa $68 \mathrm{mg}$ etonogestrel trong 1 nang nhựa dẻo không phân hủy. Được đưa ra thị trường từ năm 2006, que cấy Implanon NXT ® hiện nay có chiều dài $40 \mathrm{~mm}$, đường kính $2 \mathrm{~mm}$, được cây dưới da ở mặt trong cánh tay không thuận trong tuần đâu tiên của chu kỳ kinh nguyệt.

Sự giải phóng etonogestrel chậm, ổn định và giảm dần theo thời gian, gây ra: ngăn chă̆n sự rụng trứng trong ít nhất 30 tháng (bằng cách ức chế đỉnh LH). Đây là cơ chế tránh thai chính, ngoài ra thuốc cũng có tác dụng làm đặc chất nhầy cổ tử cung, ngăn sự xâm nhập của tinh trùng, làm teo niêm mạc tử cung, ngăn sự làm tổ và thay đổi nhu động của vòi tử cung

Implanon $®$ là một biện pháp tránh dài hạn có hồi phục với nhiều ưu điểm vượt trội so với các phương pháp tránh thai ngắn hạn khác (viên uống, thuốc tiêm tránh thai, ...): hiệu quả tránh thai rất cao (chỉ số Pearl 0,1), không phụ thuộc vào sự tuân thủ của người dùng, khả năng có thai lại ngay sau khi tháo que (sau 1 tuần không còn phát hiên etonogestrel trong huyết thanh và sự rụng trứng trở lại sau $3-4$ tuần.

Một số nghiên cứu trên thế giới ghi nhận các trường hợp tránh thai thất bại của Implanon $\AA$ (có thai trong hoặc ngoài buồng tử cung) [1-2] do đă̆t sai (kỹ thuât, thời điểm) hoăc tương tác thuốc - thuốc. Được đưa vào thị trường Việt Nam từ năm 2011, que cấy tránh thai

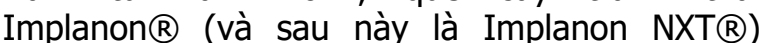
ngày càng trở nên phổ biến. Tuy nhiên cho đến nay chưa có nghiên cứu nào về tỷ lệ thất bại của biện pháp tránh thai này ở nước ta. Chúng tôi ghi nhận 1 trường hợp bênh nhân sử dụng que cây tránh thai Implanon NXT $囚$, có thai trong quá trình điều trị lao phổi.

\section{CA LÂM SÀNG}

Bênh nhân nữ 27 tuổi, PARA 1001: 01 lần đẻ thường năm 2015. Tiền sử khỏe manh, BMI 20,03 (chiều cao 1,58m, cân nặng 50kg).

Bệnh nhân được cấy que tránh thai Implanon NXT ngày 27/4/2017 tai Trung tâm tư vấn sức khỏe sinh sản - kế hoạch hóa gia đình, bệnh viện phụ sản Trung Ương. Que được cấy dưới da ở mặt trong tay trái (tay không thuân) vào tuần đầu tiên của chu kỳ kinh sau khi có kết quả khám phụ khoa bình thường và test thử thai âm tính. Sau cây que, bệnh nhân có rong kinh trên 10 ngày trong $3-4$ tháng đâu sau đó mất kinh.

Tháng 1/2018, bệnh nhân xuất hiện các triệu chứng hố hấp, đã được khám, chụp phim và làm các xét nghiệm thăm dò chẩn đoán xác định lao phổi. Bênh nhân được điêu trị lao theo phác đồ 2RHZE/4RHE (Isoniazid, Rifampicin, Pyrazinamid, Ethambutol). Trong quá trình điều trị, bệnh nhân vẫn vô kinh và không có ra máu bất thường.

Khi liệu trình điều trị lao sắp hết, bênh nhân thây bunng to lên kèm theo một số triệu chứng mệt mỏi, thèm ăn, khám phát hiện thai 18 tuần trong buồng tử cung. Kết quả siêu âm và các thăm dò cho thấy thai phát triển bình thường. Que cấy vẫn được sờ thấy và nằm đúng vị trí.

Sau 1 tuần suy nghĩ, bệnh nhân trở lại viện tháo que cấy ngày 27/6/2018 khi thai 19 tuần tuổi. Kiểm tra que cấy toàn vẹn, không thấy nứt vỡ.

Bênh nhân tiếp tục giữ thai, khám thai định kỳ, không có ra máu âm đạo trong suốt thai kỳ và chuyển da đẻ thường đủ tháng $(12 / 2018)$, Apgar $9-10$ điểm (ở 1 phút và 5 phút sau sinh) và theo dõi sơ sinh bình thường.

\section{BÀN LUÂN}

Đây là một trường hợp phụ nữ trong độ tuổi 
sinh đẻ, sử dụng que cây Implanon NXT® để tránh thai, tuy nhiên biện pháp thất bại dẫn đến có thai. Từ khi ra đời năm 1998, dù tỷ lệ tránh thai rất cao (trên 99\%) nhưng que cấy Implanon ${ }^{\circledR}$ cũng đã ghi nhận môt số báo cáo về các trường hợp có thai ngoài ý muốn. Thế hệ mới Implanon NXT $\AA$ (Nexplanon $\AA$ ) ngày càng hoàn thiện, tăng tỷ lệ tránh thai (thông qua việc giữ que cấy toàn vẹn đúng vị trí) tuy nhiên hiện tượng có thai ngoài ý muốn vẫn có thể xảy ra do một vài nguyên nhân khác nhau.

Tương tác thuốc là yếu tố quan trong ảnh hưởng đến tác dunng tránh thai của thuốc tránh thai nội tiết, đặc biệt là que cấy tránh thai. Quá trình chuyển hóa của các thuốc nội tiết này có vai trò của hệ thống enzym cytochrom P450 (CYP) trong gan. Do đó, các loại thuốc tạo ra các enzym của hệ thống CYP có thể làm tăng đào thải steroid (giảm nồng độ thuốc tránh thai trong máu), dẫn đến giảm khả năng tránh thai [3]. Một loạt các chất cảm ứng enzym manh gây ảnh hưởng này bao gồm: một số thuốc chống động kinh (carbamazepine, oxcarbazepine, phenytoin, phenobarbital, primidone, topiramate) [4], kháng sinh (rifampicin, rifabutin) [5], thuốc chống nấm (griseofulvin), thuốc ức chế protease (amprenavir, atazanavir, nelfinavir, lopinavir, saquinavir, ritonavir) và thuốc ức chế men sao chép ngược không nucleoside (efavirenz, nevirapine) [6].

Bệnh nhân của chúng tôi đã được điều trị lao bằng rifampicin-isoniazid trong khi sử dụng Implanon NXT R. Etonogestrel được chuyển hóa bởi hệ thống enzym CYP3A4 và rifampicin là chất cảm ứng, nhưng isoniazid gây ức chế hệ thống enzym này. Tác động cạnh tranh của rifampicin và isoniazid lên chuyển hóa của các thuốc chưa rõ ràng nhưng tác dụng cảm ứng enzym này làm giảm nồng độ etonogestrel trong huyết tương có thể giải thích cho sư tránh thai thất bai dẫn đến có thai ở bệnh nhẩn này. Các chuyên gia đều đồng thuận rằng nên kết hợp một biện pháp tránh thai rào cản khi đang sử dụng que cấy tránh thai với những trường hợp sử dụng các thuốc cảm ứng enzym trên, không chỉ trong khi dùng thuốc mà đến 28 ngày sau khi dừng thuốc. Những phụ nữ điều trị thuốc cảm ứng enzym này trong thời gian dài nên được tư vấn tháo que cây và sử dụng biện pháp tránh thai không nội tiết.

Ngoài ra, y văn cũng ghi nhận các trường hợp tránh thai thất bại dẫn đến có thai trong hoặc ngoài buồng tử cung với que cấy tránh thai Implanon do các nguyên nhân về kỹ thuật hoặc chỉ định.
Yếu tố hay gặp nhất dẫn đến thất bại trong tránh thai là do que nang etonogestrel không được cấy đúng cách. Nghiên cứu tại Úc năm 2005 cho thấy 40\% các trường hợp mang thai do cấy que không thành công (que cấy không được đưa vào hoặc đưa vào không đúng vị trí) [2]. Ngoài ra, sự toàn vẹn của nang cấy cũng được đề câp đến như mốt yếu tố nguy cơ làm thay đổi hiệu quả của thuốc khi nang không toàn vẹn, thay đổi diện tích bề mặt dấn đến giải phóng quá nhiều hoặc quá ít progestin [7]. Tuy nhiên, bênh nhân của chúng tôi không xảy ra các tình huống này do que cấy luôn được sờ thấy ở đúng vị trí và khi tháo thấy que hoàn toàn nguyên vẹn.

Thời điểm cấy que cũng rất quan trong, có thể ảnh hưởng đến tỷ lệ tránh thai thất bại. Khoảng $30 \%$ số ca có thai khi cấy que Implanon do người phụ nữ đã có thai từ trước hoặc cấy que muộn trong chu kỳ [2]. Việc loại trừ có thai trước khi cấy que bằng hỏi bệnh và các thăm khám lâm sàng, cận lâm sàng là thực sự cần thiết. Que cấy nên được cấy vào đầu chu kỳ kinh (tốt nhất là 5 ngày đẩu tiên của chu kỳ), ngoài thời gian trên cần áp dụng thêm biện pháp tránh thai rào chắn trong khoảng $1-2$ tuần.

Cũng như nhiều loại thuốc khác, trọng lượng cơ thể và chỉ số khối BMI của bệnh nhẩn cũng là một yếu tố cẩn được cân nhắc khi dùng phương pháp tránh thai nội tiết. Que cấy tránh thai Implanon với hàm lượng cố định cho tất cả phụ nữ, nồng độ etonogestrel trong huyết thanh tỷ lệ nghịch với chỉ số khối cơ thể (BMI). Do đó những phụ nữ thừa cân có nguy cơ mang thai cao hơn khi sử dụng que cấy tránh thai, đặc biệt là các trường hợp béo phì ( BMI trên 32,2) [8].

Có rất ít dữ liệu lâm sàng ở phụ nữ tiếp xúc với etonogestrel trong thời kỳ mang thai, nhưng không có tác dụng gây quái thai nào được báo cáo cho đến nay, đặc biệt là không có hiện tươnng nam hóa. Trong thai kỳ nên tháo que cấy tuy nhiên không thể tháo que (có thể do lạc chỗ) cũng không phải chỉ định đình chỉ thai [9].

Trong trường hợp tránh thai thất bai, cân xác định vị trí và sự phát triển của thai. Chửa ngoài cung là biến chứng hay gặp của các biện pháp tránh thai nội tiết. Cơ chế được cho là liển quan đến giảm co bóp cơ trơn của ống vòi tử cung [1].

Vô kinh là một tác dụng phụ hay gặp của que cấy tránh thai, do đó việc chẩn đoán sớm thai nghén khi cấy que đôi khi khó khăn nếu các triệu chứng nghén không rõ ràng, ảnh hưởng đến việc quyết đinh tiếp tục thai nghén hoăcc can thiểp nếu chửa ngoài tử cung. Ở trường hợp này, 
bệnh nhân phát hiện có thai khi thai đã 18 tuần tuổi, việc tiếp tục theo dõi thai đôi khi mang lại lo lắng, tuy nhiên không có bất thường nào được tím thấy trong suốt quá trình theo dõi.

Để tránh nguy cơ mang thai trong khi tránh thai bằng que cấy, các chuyên gia đều đồng thuận về quy trình nghiêm ngặt trong đào tạo bác sỹ thực hành, đảm bảo nang thuốc được đưa vào đúng vị trí. Thế hệ que cấy mới có chất cản quang giúp dễ phát hiện khi que cấy lạc chỗ. Ngoài ra, việc tư vấn cho người phụ nữ tự sờ que cấy và thông báo cho bác sỹ về sự có mặt của que cấy mối khi thăm khám ở tất cả các chuyên khoa là rất cần thiết.

\section{KẾT LUÂN}

Trường hợp bệnh nhân này là một minh họa cho việc tương tác thuốc của que cấy tránh thai với thuốc cảm ứng enzyme ở gan làm giảm tác dụng tránh thai, dẫn đến có thai ngoài ý muốn, chưa phát hiện thấy bất thường ở thai nhi cũng như các thăm khám sơ sinh. Cần thận trong với các tương tác này trong các chỉ định chẩn đoán và điều trị đặc biệt với các bệnh lý toàn thân.

\section{TÀI LIÊU THAM KHẢO}

1. R. Callahan, I. Yacobson, V. Halpern và cộng sứ (2015). Ectopic pregnancy with use of progestin-only injectables and contraceptive implants: a systematic review. Contraception, 92
(6), 514-522.

2. M. Harrison-Woolrych và R. Hill (2005). Unintended pregnancies with the etonogestrel implant (Implanon): a case series from postmarketing experience in Australia. Contraception, 71 (4), 306-308.

3. Organon Laboratories Ltd. Implanon $68 \mathrm{mg}$ implant for subdermal use: Summary of Product Characteristics (SPC). September 2009. Available at http://www.medicines.org.uk/ EMC/medicine/ 5382/SPC/Implanon+ 68mg+implant+for+ subdermal +use/ Accessed Jun 19, 2010.,

4. A. Lazorwitz, A. Davis, M. Swartz và công sự (2017). The effect of carbamazepine on etonogestrel concentrations in contraceptive implant users. Contraception, 95 (6), 571-577.

5. A. M. Baciewicz, C. R. Chrisman, C. K. Finch và cộng sự (2008). Update on rifampin and rifabutin drug interactions. Am J Med Sci, 335 (2), 126-136.

6. N. Leticee, J. P. Viard, A. Yamgnane và cộng sư (2012). Contraceptive failure of etonogestre implant in patients treated with antiretrovirals including efavirenz. Contraception, 85 (4), 425-427.

7. A. Elliman (2013). Removal of a fractured Nexplanon ${ }^{\circledR}$. J Fam Plann Reprod Health Care, 39 (1), 66-67.

8. L. M. Lopez, A. Bernholc, M. Chen và cộng sự (2016). Hormonal contraceptives for contraception in overweight or obese women. Cochrane Database Syst Rev, (8), Cd008452.

9. Centre de référence des agents tératogènes. Étonogestrel. 4 Mai 2021; Available from: http://lecrat.fr/articleSearchSaisie.php?recherche= etonogestrel.

\section{ĐÁNH GIÁ PHÂN LOẠI MỨC Độ ĐIỀU KIỀN LAO ĐộNG Ở LÁI XE KHÁCH ĐƯờ'NG DẦI}

\section{TÓM TẮT}

Mục tiêu: đánh giá mức độ điều kiện lao động ở lái xe khách đường dài. Phương pháp nghiên cứu: 200 nam lái xe khách đường dài tuyến cố định liên tỉnh với tuổi đời trung bình là 40,9 95,6 tuổi và tuổi nghề trung bình là $12,4 \pm 5,6$ năm đã tham gia nghiên cứu. Các lái xe được đo một số các yếu tố môi trường lao động, yếu tố tâm sinh lý lao động và đánh giá theo công văn số 2753/LĐTBXH-BHLĐ của Bộ Lao động - Thương binh và Xã hội. Kết quả: Điểm tổng hợp các yếu tố điều kiện lao động ở lái xe khách đường dài được đánh giá là 49,8 điểm; tương ứng với mức IV theo phân loai điều kiện lao động ở công văn

*Viện Sức khỏe nghề nghiệp và Môi trường

Chịu trách nhiệm chính: Nguyễn Thu Hà

Email: thuhayhld@gmail.com

Ngày nhận bài: 15.6 .2021

Ngày phản biên khoa họ: 10.8.2021

Ngày duyệt bài: 16.8.2021
Nguyễn Thu Hà*, Nguyễn Đức Sơn*

số 2753/LĐTBXH-BHLĐ của Bộ Lao động - Thương binh và Xã hội. Số các chỉ tiêu điều kiện lao động có mức xếp điểm $\geq 4$ trong tổng số các yếu tố điều kiện lao đông được đánh giá là 5 chỉ tiêu. Kết luân: việc thực hiện các giải pháp cải thiện điều kiện lào động cho lái xe để tăng cường khả năng làm việc và tránh các ảnh hưởng xấu tới sức khoẻ người lao động khi làm việc nhiều năm là rất cần thiết.

Từ khoá: Điều kiện lao động, lái xe khách đường dài, môi trường lao động, phân loại lao động, tâm sinh lý lao động

\section{SUMMARY \\ ASSESSMENT OF WORKING CONDITIONS IN LONG DISTANCE DRIVER}

Objectives:This study was carried out to assess the level of working conditions in long distance drivers. Methods: 200 male drivers with $40.9 \pm 5.6$ years of age and $12.4 \pm 5.6$ participated in this study. Drivers are measured some working environmental factors, psycho-physiological of work factors and 